\title{
STUDI DINAMIKA MEKANISME PILKADA DI INDONESIA DAN PERBANDINGAN MEKANISME PILKADA NEGARA LAINNYA
}

(Study of Dynamics Process in the Local Election for Regional Leaders in Indonesia and the Comparison Study of Election Mechanism for Regional Leaders in Other Countries)

\author{
Loura Hardjaloka \\ Fakultas Hukum Universitas Indonesia \\ Kampung Sawah Tanah Wakap No. 15, RT 013 RW 006, Jembatan Lima, Jakarta Barat. \\ Email: loura.hardjaloka@gmail.com
}

Naskah diterima: 5 Februari 2015; revisi: 24 April 2015; disetujui: 30 April 2015

\begin{abstract}
Abstrak
Frasa "dipilih secara demokratis" dalam Pasal 18 ayat (4) Undang-Undang Dasar 1945 selalu ditafsirkan bahwa pemilihan kepala daerah harus dilakukan secara langsung oleh rakyat. Untuk memahami tafsiran sesungguhnya, tulisan ini akan membahas mengenai tafsiran ketentuan tersebut terhadap mekanisme pemilihan kepala daerah, disamping itu akan dibahas pula dinamika pemilihan kepala daerah (termasuk di daerah istimewa) di Indonesia dari masa ke masa, dan perbandingan sistem pemilihan kepala daerah di negara lainnya. Melalui penelitian yuridis normatif, diketahui bahwa secara konstitusional makna frasa tersebut dapat diartikan dalam bentuk pemilihan langsung dan pemilihan oleh Dewan Perwakilan Rakyat Daerah. Terhadap mekanisme pemilihan kepala daerah di Negara lain pada dasarnya juga pernah diterapkan di Indonesia. Akan tetapi, berdasarkan kisruh yang terjadi beberapa lalu terkait pemilihan kepala daerah di Indonesia melalui pemilihan Dewan Perwakilan Rakyat Daerah memunculkan isyarat bahwa rakyat lebih puas dengan pemilihan langsung. Sebaliknya di daerah istimewa Yogyakarta, rakyat lebih puas untuk tetap menetapkan turunan Sultan yang menjadi pemimpin mereka. Dengan demikian, alangkah baiknya pemerintah memperhatikan aspirasi rakyat sebelum mengubah mekanisme pemilihan kepala daerah untuk meminimalisir terjadinya kisruh.
\end{abstract}

Kata Kunci: tafsiran, demokratis, pemilihan, perbandingan, kepala daerah

\section{Abstract}

The phrase "shall be elected democratically" in Article 18 paragraph (4) of the 1945 Constitution of Indonesia is always interpreted that regional leaders shall be elected directly by the people. According to that, this paper will discuss the provisions interpretation about election system for regional leaders, the dynamic system in the local election for regional leaders (including in special regions) in Indonesia, and comparison with other countries. Through normative juridical research, the constitutional meaning of the phrase can be interpreted both as direct election and election by the Local Council. The local election for regional leaders in other countries basically has been applied in Indonesia. However, based on the protest that occurred related to the election by the Local Council gave us a sign that people prefer direct election. Unlike in Yogyakarta, as a special region in Indonesia, the Yogya's people prefer to be led by Sultan's descendant. Thus, in the future, government should understand people's will before changing the election system for regional leaders to minimize conflicts.

Keywords: interpretation, democracy, election, comparative, local leaders 


\section{A. Pendahuluan}

Selama kurun waktu 1999-2002, amandemen Undang-Undang Dasar 1945 ("UUD 1945") dilakukan untuk mewujudkan demokratisasi di Indonesia. Amandemen yang dilakukan selama empat tahap ${ }^{1}$ tersebut membawa perubahan besar dalam sistem ketatanegaraan Indonesia, diantaranya ditandai dengan penegasan konstitusional bahwa Indonesia sebagai negara hukum yang demokratis ${ }^{2}$, pengaturan kembali hubungan antara pusat dan daerah dalam tatanan otonomi daerah di Indonesa, dan diterapkannya aturan pengisian jabatan politik khususnya di lingkup eksekutif.

Pengisian jabatan negara (staatsorganen, staatsambten) merupakan salah satu unsur penting dalam hukum tata negara. ${ }^{3}$ Dalam konsepsi Negara Kesatuan Republik Indonesia yang menerapkan desentralisasi, pengisian jabatan kepala daerah merupakan bentuk pengisian pejabat negara agar pelaksanaan fungsi pemerintahan daerah sebagai bagian dari pemerintahan pusat dapat terlaksana. Mekanisme pengisian jabatan kepala daerah dimaksudkan untuk memilih pemimpin di level daerah yang akan menjalankan fungsi pemerintah daerah.

Pasal 18 ayat (4) UUD 1945 paska amandemen menyebutkan bahwa pengisian jabatan kepala daerah harus dilaksanakan dengan pemilihan secara demokratis. Meskipun demikian, tidak dijelaskan lebih lanjut bagaimana makna "dipilih secara demokratis" sehingga dapat bermakna ganda (ambigous), artinya ada alternatif bisa dipilih langsung atau tidak langsung/ perwakilan dengan ketentuan demokratis. Ketiadaan penjelasan lebih lanjut atas makna "dipilih secara demokratis" mengakibatkan banyaknya penafsiran yang berbeda sehingga menghasilkan berbagai mekanisme pengisian jabatan pada masingmasing rezim pemerintahan. Keberagaman model mekanisme pengisian jabatan kepala daerah tersebut memunculkan asumsi bahwa pemerintahan yang mengaku menerapkan prinsip demokrasi dapat memaknai pengisian jabatan kepala daerah dalam berbagai mekanisme, termasuk pemaknaan terhadap pemilihan secara demokratis sebagaimana diatur dalam konstitusi yang berlaku saat ini. Dengan demikian, bisa dikatakan makna demokrasi menjadi ambigu ketika dilihat dalam praktek pengisian jabatan kepala daerah di Indonesia selama ini. Adapun keberagaman mekanisme pengisian jabatan kepala daerah tidak hanya terjadi di Indonesia melainkan juga di banyak Negara di dunia.

Adanya keberagaman mekanisme pemilihan kepala daerah yang ditimbulkan dari ketidakjelasan makna "dipilih secara demokratis" berdasarkan Pasal 18 ayat (4) UUD 1945 dan dinamikanya penting untuk dibahas mengingat banyak pihak khususnya regulator seringkali salah menafsirkan Pasal 18 ayat (4) UUD 1945 dan melupakan dinamika 
pemilihan kepala daerah yang pada dasarnya terjadi karena ketidakpuasan atas mekanisme pemilihan kepala daerah sebelumnya.

Terhadap hal tersebut, ketidakpuasan rakyat akibat kesalahan menetapkan sistem pemilihan kepala daerah oleh pemerintah akhirnya menimbulkan kisruh seperti dalam kasus Undang-Undang Nomor 22 Tahun 2014 tentang Pemilihan Gubernur, Bupati, dan Walikota karena penolakan rakyat atas mekanisme pemilihan kepala daerah melalui pemilihan oleh DPRD sehingga mengharuskan pemerintah untuk menerbitkan Peraturan Pemerintah Pengganti Undang-Undang Nomor 1 Tahun 2014 tentang Pemilihan Gubernur, Bupati, dan Walikota bahwa kepala daerah akan dipilih langsung oleh rakyat melalui mekanisme pemilihan umum sedangkan wakil kepala daerah akan diangkat oleh Presiden/Menteri sesuai dengan tingkat daerah, dapat dikatakan sesuai dengan konstitusi dan dapat dianggap demokratis; dan pengisian jabatan Daerah Istimewa Yogyakarta ("DIY") yang mana pada saat itu Presiden Susilo Bambang Yudhoyono menyatakan bahwa pengisian jabatan di DIY yang bersifat monarki bertabrakan dengan Pasal 18 ayat (4) UUD 1945 yang mengamanatkan untuk pengisian jabatan dipilih secara demokratis. Meskipun saat ini kisruh pengisian jabatan di DIY telah berakhir dengan diterbitkannya Undang-Undang No. 13 Tahun 2012 tentang Keistimewaan DIY yang pada akhirnya menetapkan bahwa pada intinya pengisian jabatan DIY tetap turun temurun.

Berdasarkan latar belakang tersebut, adapun permasalahan yang akan dibahas dalam tulisan ini adalah (i) bagaimana konsep pemerintahan daerah dalam Negara kesatuan; (ii) bagaimana penafsiran Pasal 18 ayat (4) UUD 1945 terhadap mekanisme pemilihan kepala daerah secara umum; (iii) bagaimana mekanisme rekrutmen jabatan kepala eksekutif di banyak negara; dan (iv) bagaimana dinamika mekanisme pemilihan kepala daerah di Indonesia termasuk di daerah istimewa.

\section{B. Metode Penelitian}

Penelitian ini adalah penelitian hukum normatif yang dilakukan menggunakan penelitian kepustakaan untuk mendapatkan data sekunder dengan bahan atau materi berupa buku-buku, artikel-artikel, hasil-hasil penelitian, dan pendapat ahli yang berkaitan dengan penerapan sistem pemilihan umum kepala daerah di Indonesia dan Negara lainnya. Dalam pengumpulan data maka dilakukan dengan studi dokumen dan literatur-literatur yang berkaitan dengan tema penelitian dengan menggunakan (i) Bahan Primer, yang mencakup peraturan perundang-undangan yang berkaitan dengan pokok permasalahan penelitian; dan (ii) Bahan Sekunder, terdiri dari hasil-hasil penelitian yang telah ada sebelumnya yang terkait dengan permasalahan penelitian dan kepustakaan, termasuk bahan dan hasil seminar dan konferensi-konferensi. Berdasarkan data dan informasi yang sudah diperoleh, akan dilakukan analisis kualitatif yakni suatu cara penelitian yang menghasilkan data deskriptif analitis, yaitu apa yang ditemukan dalam praktek dan literatur diteliti dan dipelajari sebagai sesuatu yang utuh.

\section{Pembahasan}

\section{Pemerintahan Daerah dalam Negara Kesatuan}

Pembahasan mengenai pemerintahan daerah tidak dapat terlepas dari bentuk negara dan susunan negara. Dalam tulisan ini, penulis memberikan batasan bahwa istilah bentuk negara ditujukan pada monarki dan republik, 
sedangkan istilah susunan negara ditujukan pada kesatuan dan federal. Secara singkat, bentuk dan susunan Negara dijabarkan dalam tabel berikut ini.

Tabel 1. Bentuk dan Susunan Negara

\begin{tabular}{|c|c|c|c|}
\hline \multicolumn{2}{|c|}{ BENTUK NEGARA ${ }^{4}$} & \multicolumn{2}{|c|}{ SUSUNAN NEGARA ${ }^{5}$} \\
\hline Monarki & Republik & Federal & \\
\hline $\begin{array}{l}\text { - Penentuan kepala negara } \\
\text { dilakukan berdasarkan } \\
\text { prinsip pewarisan. } \\
\text { - Pengambilan } \\
\text { keputusan dilakukan } \\
\text { tidak oleh majelis } \\
\text { yang mencerminkan } \\
\text { representasi rakyat }\end{array}$ & $\begin{array}{l}\text { - Mekanisme penentuan } \\
\text { kepala negara dilakukan } \\
\text { melalui pemilihan } \\
\text { (langsung atau melalui } \\
\text { majelis) dengan } \\
\text { periodesasi masa jabatan } \\
\text { yang telah ditentukan. } \\
\text { - Pengambilan keputusan } \\
\text { didalam negara } \\
\text { dilakukan oleh majelis } \\
\text { representasi rakyat atau } \\
\text { memperhatikan aspirasi } \\
\text { publik. }\end{array}$ & $\begin{array}{l}\text { - Terdiri atas tiga struktur } \\
\text { tingkatan utama, yaitu } \\
\text { pemerintah federal } \\
\text { (pusat), pemerintah } \\
\text { negara bagian (provinsi), } \\
\text { dan daerah otonom. } \\
\text { - Kekuasaan atau } \\
\text { kewenangan berasal } \\
\text { dari bawah atau dari } \\
\text { negara bagian yang } \\
\text { bersepakat untuk } \\
\text { menyerahkan sebagian } \\
\text { kewenangannya kepada } \\
\text { pemerintah federal, } \\
\text { yang biasanya secara } \\
\text { eksplisit tercantum } \\
\text { dalam konstitusi } \\
\text { negara federal. Dengan } \\
\text { demikian, kewenangan } \\
\text { pemerintah pusat dengan } \\
\text { demikian akan menjadi } \\
\text { terbatas atau limitatif } \\
\text { dan daerah memiliki } \\
\text { kewenangan luas } \\
\text { (general competence). } \\
\text { Wewenang untuk } \\
\text { penyelenggaraan } \\
\text { desentralisasi } \\
\text { sepenuhnya adalah } \\
\text { pemerintah Negara } \\
\text { bagian. } \\
\text { Hubungan antara } \\
\text { pemerintah federal } \\
\text { dengan negara bagian } \\
\text { tidak otomatis hierarki. }\end{array}$ & $\begin{array}{l}\text { - Terdiri atas dua struktur } \\
\text { tingkatan utama, yaitu } \\
\text { pemerintah pusat dan } \\
\text { pemerintah daerah } \\
\text { (provinsi, kabupaten dan } \\
\text { kota). } \\
\text { Kewenangan pada } \\
\text { dasarnya berada atau } \\
\text { dimiliki oleh pemerintah } \\
\text { pusat yang kemudian } \\
\text { diserahkan atau } \\
\text { dilimpahkan lepada } \\
\text { daerah. Penyerahan atau } \\
\text { pelimpahan kewenangan } \\
\text { di Negara kesatuan } \\
\text { biasanya dibuat secara } \\
\text { eksplisit (ultravires). } \\
\text { Dengan demikian, } \\
\text { setiap daerah memiliki } \\
\text { kewenangan terbatas. } \\
\text { Wewenang untuk } \\
\text { penyelenggaraan } \\
\text { desentralisasi } \\
\text { sepenuhnya adalah } \\
\text { wesentralisasi cenderung } \\
\text { diletakkan dalam } \\
\text { konstitusi, dimana } \\
\text { hubungan antara } \\
\text { pemerintah pusat } \\
\text { dengan daerah adalah } \\
\text { hierarki. }\end{array}$ \\
\hline
\end{tabular}

Sumber: Diolah dari Berbagai Sumber 
Berdasarkan pemaparan di atas, dapat disimpulkan bahwa Indonesia adalah negara yang berbentuk Negara Kesatuan (unitry state) dengan kekuasaan asal berada di pemerintah pusat namun kewenangan (authority) pemerintah pusat ditentukan batas-batasnya dalam UUD 1945 atau Undang-Undang ("UU") yang ditentukan sebagai kewenangan yang dimiliki oleh pemerintah daerah. Hubunganhubungan kekuasaan antara pemerintah pusat dan pemerintah daerah provinsi serta pemerintah daerah kabupaten dan kota, tidak hanya diatur berdasarkan asas dekonsentrasi, melainkan juga didasarkan atas asas otonomi atau desentralisasi dan tugas perbantuan. Disamping itu, dalam rumusan Pasal 18, Pasal $18 \mathrm{~A}$ dan Pasal 18B (seluruhnya sebanyak 11 ayat) UUD 1945, ditegaskan pula adanya pengakuan atas pluralisme di berbagai daerah. Dengan ketentuan-ketentuan konstitusional demikian, berarti Negara Kesatuan Republik Indonesia diselenggarakan dengan pengaturan antar daerah yang tidak seragam antara satu sama lain atau bersifat federalistis. ${ }^{6}$

\section{Mekanisme Pemilihan Kepala Daerah} di Indonesia Berdasarkan Perspektif Pasal 18 ayat (4) UUD 1945

\section{a. Pasal 18 ayat (4) UUD 1945: Sebuah Tinjauan Historis}

Pada dasarnya, di dalam rapat-rapat pembahasan Amandemen Kedua UUD 1945, banyak fraksi yang tergabung dalam Panitia Perubahan Kedua UUD 1945 menginginkan pemilihan kepala daerah (selanjutnya disingkat dengan "KDH") dilakukan secara langsung oleh rakyat mengingat roh demokratisasi ialah menegakkan prinsip demokrasi "dari rakyat, oleh rakyat, dan untuk rakyat" atau melaksanakan sistem presidensial yang mengharuskan pemimpin dipilih langsung oleh rakyat. ${ }^{7}$

Akan tetapi, mengingat pembahasan substansi pemilihan KDH seperti yang dimaksud didalam Pasal 18 ayat (4) UUD 1945 dilakukan secara bersamaan dengan pembahasan substansi yang memperhatikan (i) kekhususan dan keragaman daerah seperti yang tercantum di dalam Pasal 18A UUD 1945; (ii) substansi mengenai pengakuan dan penghormatan terhadap satuan-satuan pemerintahan daerah yang bersifat khusus; serta (iii) kesatuankesatuan masyarakat hukum adat beserta hak-hak tradisionalnya seperti yang dimaksud di dalam Pasal 18B UUD 1945; maka dengan memperhatikan hal tersebut dan juga tidak menyamaratakan antara daerah otonom dengan daerah khusus atau istimewa, sebagai jalan tengahnya rumusan Pasal 18 ayat (4) UUD 1945 tidak dirumuskan dengan "dipilih secara langsung", tetapi "dipilih secara demokratis".

\section{b. Meninjau Substansi Pasal 18 ayat (4) UUD 1945 Terhadap Mekanisme Pemilihan KDH}

Mekanisme pengisian jabatan $\mathrm{KDH}$, baik itu pada tingkat provinsi, kabupaten/kota diatur di dalam Perubahan ke-II UUD 1945, Pasal 18 ayat (4) menegaskan: "Gubernur, Bupati, dan Walikota masing-masing sebagai kepala pemerintahan propinsi, kabupaten, dan kota dipilih secara demokratis."

Loc.cit.

Dahlan Thaib, Ketatanegaraan Indonesia Perspektif Konstitusional (Yogyakarta: Penerbit Total Media, 2011), hlm. 24.

8 Risalah Rapat Pembahasan Perubahan Kedua UUD NRI Tahun 1945 pada tanggal 29 Juli 2000. 
Terhadap pasal tersebut, Jimly Asshiddiqie dan Mahfud MD berpendapat bahwa ketentuan pemilihan secara demokratis dalam ayat (4) ini dapat dilaksanakan, baik melalui cara pemilihan langsung oleh rakyat atau dengan cara tidak langsung melalui Dewan Perwakilan Rakyat Daerah ("DPRD"). Kedua cara itu sama-sama demokratis, dan karena itu konstitusional. Hanya saja, dewasa ini ketentuan ini dijabarkan lebih lanjut dalam UU, yaitu bahwa pemilihan $\mathrm{KDH}$ dilakukan melalui pemilihan umum. Namun, apabila suatu ketika akan diadakan perubahan sehingga pemilihan cukup diadakan secara tidak langsung melalui DPRD, maka hal itu juga harus dipandang sama demokratisnya dan samasama konstitusionalnya. ${ }^{9}$ Meskipun demikian, menurut Bhenyamin Hoessein kata demokratis tidak dapat diartikan bahwa pemilihan KDH harus melalui mekanisme tertentu namun lebih dititikberatkan pada pemilihan KDH dilakukan dengan cara bebas dari politik uang (money politic) dan sesuai dengan aspirasi masyarakat. ${ }^{10}$

Dengan demikian, kombinasi mekanisme pemilihan KDH dalam Peraturan Pemerintah Pengganti Undang-Undang Nomor 1 Tahun 2014 tentang Pemilihan Gubernur, Bupati, dan Walikota bahwa KDH akan dipilih langsung oleh rakyat melalui mekanisme pemilihan umum sedangkan wakil KDH akan diangkat oleh Presiden/Menteri sesuai dengan tingkat daerah, dapat dikatakan sesuai dengan konstitusi dan dapat dianggap demokratis.

\section{Mekanisme Rekrutmen dalam Rangka Pengisian Jabatan Kepala Eksekutif di Banyak Negara}

Dengan desentralisasi, terbentuklah provinsi, kabupaten, dan kota yang mana masing-masing daerah otonomi tersebut dipimpin oleh gubernur sebagai KDH provinsi, bupati sebagai $\mathrm{KDH}$ kabupaten, dan walikota sebagai KDH kotamadya, yang mana masingmasing $\mathrm{KDH}$ akan didampingi oleh seorang wakil kepala daerah (selanjutnya disebut sebagai wakil KDH), serta DPRD. Khusus untuk provinsi, disamping sebagai daerah otonom dalam rangka desentralisasi, terdapat juga daerah administasi sebagai bentuk dekonsentrasi. Oleh karena itu, $\mathrm{KDH}$ juga berperan sebagai wakil pemerintah dalam rangka dekonsentrasi. ${ }^{11}$

Menurut Samuel Humes dan Eileen Marten, keberagaman pengisian jabatan kepala daerah juga telah banyak dikenal dan banyak dipraktekkan di beberapa Negara di dunia, yang mana dilakukan dengan cara (i) $\mathrm{KDH}$ diangkat oleh pemerintah pusat atau unit yang lebih tinggi; (ii) $\mathrm{KDH}$ dipilih oleh dewan; (iii) $\mathrm{KDH}$ dipilih melalui pemilihan umum; dan (iv) $\mathrm{KDH}$ diangkat oleh dewan. ${ }^{12}$ Selain poin iv, seluruh mekanisme tersebut telah dijalankan di Indonesia sesuai dengan peraturan perundangundangan yang berlaku (yang akan dibahas dalam bab selanjutnya). Adapun poin iv sempat akan dijalankan melalui Undang-Undang Nomor 22 Tahun 2014 tentang Pemilihan Gubernur, Bupati, dan Walikota namun mengingat

Jimly Asshiddiqie, Komentar Atas Undang-Undang Dasar Negara Republik Indonesia Tahun 1945 (Jakarta: Sinar Grafika, 2009), hlm.59.

10 Bhenyamin Hoessein, Perubahan Model, Pola, dan Bentuk Pemerintahan Daerah: Dari Era Baru ke Era Reformasi (Jakarta: FISIP UI, 2009), hlm. 150.

11 I Gde Pantja Astawa, Problematika Hukum Otonomi Daerah di Indonesia (Jakarta: PT. Alumni, 2012), hlm. 215.

12 Samuel Humes and Eileen Martin, The Structure of Local Goverment, A Comparative Survey of 81 Countries (The Hogue: International Union Local Authority, 2011), hlm. 137- 144. 
mekanisme pemilihan $\mathrm{KDH}$ secara tidak langsung melalui DPRD telah mendapatkan penolakan yang luas oleh rakyat dan proses pengambilan keputusannya telah menimbulkan persoalan serta kegentingan yang memaksa sesuai Putusan Mahkamah Konstitusi Nomor 138/PUU-VII/2009, maka peraturan tersebut dicabut dan dinyatakan tidak berlaku dengan Peraturan Pemerintah Pengganti UndangUndang Nomor 1 Tahun 2014 tentang Pemilihan Gubernur, Bupati, dan Walikota.
Penyelenggaraan pemerintahan daerah baik di Indonesia dan sejumlah Negara lainnya secara umum menggunakan tiga mekanisme untuk memilih kepala eksekutif, yakni (i) $\mathrm{KDH}$ dipilih langsung; (ii) dipilih secara tidak langsung oleh dewan; dan (iii) ditunjuk oleh pemerintah pusat. ${ }^{13}$ Secara singkat, mekanisme rekrutmen pengisian jabatan kepala eksekutif secara umum yang dijalankan di banyak Negara adalah sebagai berikut:

Tabel 2. Mekanisme Rekrutmen Pengisian Jabatan Kepala Eksekutif di Banyak Negara

\section{KEPALA EKSEKUTIF DIANGKAT OLEH PEMERINTAH PUSAT/UNIT YANG LEBIH TINGGI}

Ketentuan Umum Peran KDH sangat dipengaruhi oleh mekanisme pemilihannya, apakah oleh pemerintah pusat, dewan, atau melalui pemilihan umum. Pilihan terhadap mekanisme ini, merupakan salah satu penentu tingkat keterwakilan pemerintah dan pertanggungjawaban kepala eksekutif kepada rakyatnya. Melalui mekanisme pengangkatan kepala eksekutif oleh pemerintah pusat atau unit yang lebih tinggi, berarti seleksi yang dilakukan oleh unit lokal lebih sedikit. ${ }^{14}$

Dewasa ini sudah banyak praktek pemerintah pusat mengangkat kepala eksekutif, sedangkan pada tingkat kota ada kecenderungan selama abad terakhir semua kepala eksekutif dipilih, sementara perubahan dari gubernur yang diangkat menjadi dipilih, sementara perubahan dari gubernur yang diangkat menjadi dipiilih secara lokal terjadi lebih lambat. ${ }^{15}$

Banyak kepala eksekutif yang diangkat dari pusat merupakan pegawai pemerintah sipil pusat. Di banyak negara, kepala eksekutif daerah diangkat oleh unit yang lebih tinggi dan bukan merupakan pejabat pemerintah pusat. Kepala eksekutif merupakan orang yang memiliki pengalaman administratif atau politik yang cukup. ${ }^{16}$

13 Sarundajang, Pemerintahan Daerah di Berbagai Negara, Tinjauan Khusus Pemerintahan Daerah di Indonesia: Perkembangan Kondisi dan Tantangan (Jakarta: Sinar Harapan, 2012), hlm. 165-166.

14 Leo Agustino, Pilkada dan Dinamika Politik Lokal (Yogyakarta: Pustaka Pelajar, 2012), hlm. 8-9.

15 Jimly Asshiddiqie, Pokok-Pokok Hukum Tata Negara Indonesia Paska Reformasi (Jakarta: PT Bhuana Ilmu Populer, 2012), hlm. 440.

16 Dwi Andayani Budisetyowati, Hukum Otonomi Daerah di Negara Kesatuan Republik Indonesia (NKRI) (Jakarta: Roda inti Media, 2013), hlm. 32. 
Praktik di Negara Lain

\begin{abstract}
Di Negara Skandinavia, gubernur provinsi adalah pejabat dari pemerintah pusat. Dengan pengangkatan oleh pemerintah pusat membuat pemerintah pusat dapat melakukan intervensi terhadap semua area kewenangan $\mathrm{KDH} .{ }^{17}$
\end{abstract}

Di beberapa negara Asia dan Afrika, yang sebelumnya merupakan bagian dari Kerajaan Inggris, India dan Sudan misalnya, seringkali terdapat kepala eksekutif dari pusat yang diangkat untuk menjadi kepala eksekutif daerah. Dahulu praktik yang sering terjadi adalah kepala eksekutif distrik menjadi ex-officio ketua dewan kotapraja perkotaan. Susunan ini menempatkan kepala eksekutif dalam posisi yang kuat untuk mempengaruhi keputusan atau kebijakan pada pemerintahan lokal, terutama sejak staf distrik administrasi sering juga melakukan tugas administratif di unit lokal. Para pendukung sistem ini terkoordinasi dengan kegiatan lokal dan unit kabupaten untuk mengeliminasi duplikasi fungsi. Administrator yang diangkat untuk menjadi kepala pusat kota di Sudan dan India umumnya pegawai pemerintah pusat sipil yang ditugaskan (diperbantukan) ke perkotaan. Pegawai pemerintah pusat yang menjadi kepala eksekutif memiliki hak- hak istimewa sebagai pegawai negeri sipil dan jabatannya, serta melayani secara penuh waktu sebagai kepala eksekutif di pemerintahan lokal. Di India para pejabat ini tidak pada saat yang sama menjabat sebagai ketua dewan. ${ }^{18}$

Di Malaysia, kepala eksekutif dari pusat juga sebagai pejabat KDH dan ketua dewan lokal. ${ }^{19}$ Selanjutnya, di Swedia, pemerintahan lokalnya terdiri dari 21 propinsi, yang masing-masing memiliki Badan Administrasi Propinsi. Badan Administrasi tersebut mewakili pemerintah pusat pada tingkat propinsi dan dikepalai oleh Gubernur Negara yang diangkat oleh pemerintah pusat. ${ }^{20}$

Di Belanda, pertimbangan antara kemampuan administrasi dan politik tampak dominan didalam penunjukan jabatan walikota. Pengangkatan dilakukan melalui keputusan kerajaan, yang diberlakukan oleh Kabinet atau Menteri Dalam Negeri dengan gubernur provinsi, yang biasanya memainkan peran inisiasi. Sebuah usaha dilakukan untuk menentukan orang yang secara administratif kompeten dan memiliki loyalitas politik, yang akan memungkinkan untuk bekerja sebagai kepala eksekutif dengan mudah bersama dewan lokal. ${ }^{21}$ Di Spanyol, walikota dari sebuah kotamadya dengan penduduk kurang dari 10.000 diangkat oleh gubernur provinsi, sementara walikota dari kota besar dengan penduduk lebih dari 10.000 jiwa diangkat langsung oleh Menteri Dalam Negeri. Hampir selalu jabatan walikota dan jabatan pemimpin partai lokal dipegang oleh orang yang sama. ${ }^{22}$

Di Negara Bagian Ontario Kanada, Letnan Gubernur diangkat oleh Gubernur Jendral melalui rekomendasi oleh Perdana Menteri dan Kabinet Pemerintahan Federal. Pengangkatan itu dilakukan dalam periode tidak lebih dari 5 tahun, dan menerima gaji dari pemerintah federal. Letnan Gubernur tidak dapat dipecat sebelum 5 tahun, kecuali untuk alasan yang harus dikomunikasikan kepada Senat dan DPR. ${ }^{23}$

17 John Loughlin, Frank Hendriks, and Anders Lidström, The Oxford Handbook of Local and Regional Democracy in Europe (Oxford: Oxford University Press, 2011), hlm. 263.

18 Richard C Crook and James Manor, Democracry and Decentralisation in South Asia and West Africa: Participation Accountability and Performance (United Kingdom: Cambridge University Press, 2012), hlm. 214 -216.

19 Noore Alam Siddiquee, Public Management and Governance in Malaysia: Trends and Transformations (New York: Routledge, 2012), hlm. 202.

20 Neil C. M. Elder, Government in Sweden: The Executive at Work (London: Pergamon, 2011), hlm. 28.

21 Rudy B. Andeweg and Galen A. Irwin, Governance and Politics of the Netherlands (Comparative Government and Politics) (London: Palgrave Macmillan, 2012), hlm. 215.

Hubert Heinelt and Xavier Bertrana, The Second Tier of Local Government in Europe: Provinces, Countries, Departments, and Lankreise in Comparison (New York: Routledge, 2011), hlm. 224-239.

23 David M. Thomas and David N. Biette, Canada and The United States: Differences That Count (Canada: University of Toronto Press, 2014), hlm 142-144. 
\begin{tabular}{ll}
\hline Kelebihan & KDH yang diangkat oleh dewan memiliki banyak kelebihan, antara lain (i) kepala eksekutif \\
& tersebut memiliki masa jabatan yang cukup aman, dalam arti dewan tidak dapat menjatuhkan \\
& atau memberhentikan kepala eksekutif tersebut ditengah masa jabatannya sehingga menjamin \\
& kontinuitas program dan kebijakan unit lokal; (ii) merupakan seorang yang ahli dibidang \\
& pemerintahan dan birokrasi; (iii) memiliki posisi yang berwibawa dan unggul di antara para anggota \\
& dewan; (iv) memiliki hubungan yang dekat dengan pejabat pemerintah pusat sehingga berada \\
& dalam posisi yang menguntungkan untuk mengetahui apa yang akan disetujui oleh otoritas yang \\
& lebih tinggi; ( $v$ ) dapat bertindak sebagai perantara komunikasi yang efektif antara pemerintah pusat \\
& dan daerah; (vi) tidak terpengaruh pada pasang surut politik lokal sehingga mampu bertahan di \\
& antara perselisihan partai dan politik lokal; dan (vii) biaya pengangkatan relatif minim karena tidak \\
& perlu melalui proses yang panjang dan rumit.
\end{tabular}

Kekurangan Disamping kelebihan, $\mathrm{KDH}$ yang diangkat oleh dewan juga memiliki kekurangan, antara lain (i) KDH yang diangkat oleh pusat rentan tidak mendapatkan dukungan dari dewan lokal dalam menjalankan program-programnya; (ii) kurang memiliki legitimasi yang tinggi terhadap rakyat di daerah yang dipimpin sehingga seringkali berseberangan dengan kehendak dari rakyat yang dipimpinnya; (iii) kepala eksekutif tersebut akan cenderung bergantung dan dapat dipengaruhi oleh pemerintah pusat dalam pengambilan keputusan; dan (iv) cenderung akan diintervensi oleh pemerintah pusat. ${ }^{25}$

\begin{tabular}{cl}
\hline KEPALA EKSEKUTIF DIPILIH OLEH DEWAN \\
\hline Ketentuan Umum & $\begin{array}{l}\text { Mekanisme ini merupakan mekanisme terbanyak yang digunakan di banyak Negara dalam memilih } \\
\text { walikota seperti sebagian besar di Eropa. }\end{array}$ \\
\hline
\end{tabular}

Praktik di Negara Pemilihan kepala eksekutif oleh dewan lokal sering dilaksanakan sebagai pilihan politik partisan. Lain

Salah satu pihak yang mayoritas, akan mendominasi kekuatan di dalam dewan lokal. Jika terdapat satu calon kepala eksekutif mungkin masalah akan lebih sederhana, tetapi jika tidak maka konstelasi politik lokal bisa menjadi masalah rumit. Di negara-negara Eropa, mekanisme perwakilan proporsional yang digunakan dalam pemilihan kepala eksekutif di kota sering menghalangi salah satu pihak untuk menjadi salah satu calon kepala eksekutif. Biasanya partai-partai di dewan lokal akan membentuk koalisi sehingga menjadi partai mayoritas, untuk kemudian memilih kepala eksekutif. Seperti di Belgia, secara teori, walikota di Belgia sebagai kepala eksekutif adalah wakil dari pusat, namun dalam prakteknya kepala eksekutif merupakan kepala yang dipilih oleh dewan. ${ }^{26}$

Kelebihan

Terdapat beberapa kelebihan dalam mekanisme ini, antara lain (i) biaya yang dibutuhkan relatif lebih kecil; (ii) visi dan misi akan lebih diterima oleh dewan karena pasti memiliki visi dan misi yang sama dengan dewan; (iii) dukungan dewan kepada kepala eksekutif lebih kuat dalam setiap program yang dijalankan oleh kepala eksekutif; dan (iv) meminimalisir potensi konflik horizontal. ${ }^{27}$

\footnotetext{
(2)

24 United Cities and Local Governments, Decentralization and Local Democracy in The World (Spain: World Bank, 2012), hlm 248-250.

25 J. Eric Oliver, SShang E. Ha, and ZZachary Callen, Local Elections and the Politics of Small-Scale Democracy, (United Kingdom: Princeton University Press, 2012), hlm. 245.

26 Oscar W Gabriel, [Silke I Keil, Eric Kerrouche, Political Participation in France and Germany (Europe: European Consortium for Political Research, 2012), hlm. 123.

27 John Kincaid and Nico Steytler, Local Government and Metropolitan Regions in Federal Countries (Canada: McGillQueen's University Press, 2012), hlm. 416.
} 
Terdapat beberapa kekurangan dalam mekanisme ini, antara lain (i) kepala eksekutif terpilih belum tentu merepresentasikan keinginan masyarakat setempat bahkan tak jarang dapat terjadi perbedaan antara kepentingan dan keinginan dewan dengan masyarakat; (ii) adanya ketergantungan kepala eksekutif dengan partai politik maupun anggota dewan lokal yang memilinnya (dikarenakan adanya balas budi karena telah dipilih) sehingga mudah didikte dan tidak berdaulat penuh; (iii) rentan terjadinya politik uang dan transaksi politik yang melibatkan calon kepala eksekutif dengan anggota dewan lokal; (iv) kepala eksekutif yang dipilih tidak cukup memiliki kemampuan yang cukup dalam menjalankan pemerintahan; (v) masa jabatan kepala eksekituf cenderung tidak stabil karena setiap saat dapat dijatuhkan oleh dewan lokal seperti di Perancis yang mana kepala eksekutif yang dipilih oleh dewan lokal dapat dipaksa mengundurkan diri melalui sebuah mosi tidak percaya; (vi) dewan lokal memiliki peran yang besar dalam melakukan seleksi, pemecatan, bahkan memiliki kontrol atas eksekutif tersebut; (vii) melalui mekanisme ini dapat menimbulkan faksionalisme dan cenderung mengurangi hubungan kerja yang dapat menghasilkan program efektif; (viii) pandangan kepala eksekutif cenderung didominasi dan terikat oleh pertimbangan politik guna mempertahankan kepercayaan dari mayoritas dewan. ${ }^{28}$

\section{KEPALA EKSEKUTIF DIPILIH MELALUI PEMILIHAN UMUM}

Ketentuan Umum Pemilihan langsung KDH dianggap sebagai corong utama demokrasi karena melibatkan partisipasi rakyat. Dalam demokrasi yang partisipatif, termasuk dalam pemilihan langsung KDH, dibutuhkan peran dan fungsi masyarakat yang aktif untuk mengontrol kinerja $\mathrm{KDH}$ dalam penyelenggaraan pemerintahan daerah yang baik (good local governance). ${ }^{29} \mathrm{Di}$ beberapa negara, termasuk Amerika Serikat, sejumlah besar unit lokal memilih kepala eksekutif (walikota) secara langsung melalui pemilihan umum. ${ }^{30}$

Penerapan praktek pemilihan umum pada KDH dipengaruhi oleh ide-ide 'pemisahan kekuasaan' seperti yang diungkapkan oleh Montesquieu. Pemerintah Federal Amerika Serikat mungkin adalah contoh paling terkenal dari organisasi politik yang dibentuk sesuai dengan ide-ide ini, negara dan banyak struktur pemerintah daerah telah sangat dipengaruhi oleh model nasional. Selain itu pemerintah nasional atau lokal, dan beberapa negara lain, seperti Brasil dan Filipina, telah mencontoh dari Amerika Serikat untuk mengadakan pemilihan langsung terhadap $\mathrm{KDH} .{ }^{31}$

Pemilihan kepala eksekutif secara langsung di Indonesia merupakan isu yang menarik, karena fenomena ini mengindikasikan sebuah proses politik yang akan memperkuat demokratisasi di daerah-daerah di Indonesia dan secara de facto juga memiliki konsekuensi antara lain, (i) meningkatnya kesadaran politik konstituen; (ii) meningkatkan akses masyarakat dalam rangka turut mempengaruhi keputusan pemerintah daerah terutama yang berkaitan dengan kepentingan warga; (iii) memotivasi media daerah untuk aktif terlibat dalam mempublikasikan seluruh tahapan pemilihan; (iv) mendorong berkembangnya semangat kemandirian partai politik di daerah; (v) dapat menekan sikap dan perilaku DPRD yang sering menganggap dirinya sebagai satu-satunya institusi pemegang mandat rakyat yang paling representative mengingat melalui pemilihan umum berpotensi untuk membatasi kekuasaan dan wewenang DPRD; (vi) menghasilkan KDH yang lebih berkualitas karena diuji sendiri oleh masyarakat melalui pemilihan umum; (vii) membentuk pemerintah daerah yang lebih stabil, produktif, dan efektif.

28 Ann O'M. Bowman and Richard C. Kearne, State and Local Government: The Essentials (Boston: Cengage Learning, 2014), hlm. 170.

29 Joakim Öjendal and Anki Dellnäs, The Imperative of Good Local Governance: Challenges for the Next Decade of Decentralization (United States: United Nations University Press, 2013), hlm. 250.

30 David Y Miller and Raymond Cox, Governing the Metropolitan Region: America's New Frontier (United States: Taylor \& Francis, 2014), hlm. 220.

31 Andrew Coulson and Adrian Campbell, Local Government in Central and Eastern Europe: The Rebirth of Local Democracy (New York: Routledge, 2014), hlm. 142. 
Lebih lanjut, dengan adanya pemilihan umum terhadap KDH terutama di Indonesia menciptakan check and balances yang ideal antara DPRD dan KDH. Hal ini disebabhkan keduanya memiliki legitimasi politik yang seimbang karena sama-sama dipilih langsung oleh rakyat sehingga pengalaman legislative heavy yang terjadi pada masa berlakunya UU Nomor 22 Tahun 1999 tidak terulang lagi. ${ }^{32}$

Praktik di Negara Lebih dari 70\% KDH di Amerika Serikat dipilih melalui pemilu. Dalam pemilihan umum KDH, masLain ing-masing calon yang terdaftar dapat menang apabila memiliki jumlah suara terbesar. Dalam mekanisme ini, pada umumnya calon independen memiliki kesempatan yang lebih kecil untuk menang di tempat pemungutan suara, meskipun demikian, tidak tertutup kemungkinan untuk menang di pemilihan umum. ${ }^{33}$

Di Jepang, gubernur, walikota, dan anggota DPRD dipilih langsung oleh masyarakat melalui pemilihan secara langsung. Meskipun demikian, gubernur dan walikota dapat dipecat melalui mosi tidak percaya dengan 2/3 dari suara di dewan lokal (propinsi atau kota). ${ }^{34}$ Demikian pula dengan Thailand yang memilih gubernur melalui pemilihan umum dan dapat diberhentikan melalui referendum atau dipecat oleh Menteri Dalam Negeri. ${ }^{35}$

Kelebihan

Mekanisme ini memiliki beberapa kelebihan antara lain (i) dapat menjadi sarana untuk memperkuat otonomi daerah; (ii) KDH yang terpilih akan memiliki mandat dan legitimasi yang sangat kuat; (iii) KDH tidak perlu terikat pada konsesi partai-partai atau fraksi-fraksi politik yang telah mencalonkannya; (iv) sistem pemilihan umum lebih akuntabel dan adanya akuntabilitas publik; (v) checks and balances antara lembaga legislatif dan eksekutif dapat lebih seimbang; (vi) kriteria calon KDH dapat dinilai secara langsung oleh rakyat yang akan memberikan suaranya; (vii) pemilihan umum KDH sebagai wadah pendidikan politik bagi rakyat; (viii) sebagai bentuk pengembangan demokrasi; (ix) pemilihan umum KDH memungkinkan akan meciptakan kualitas kepemimpinan nasional karena makin terbuka peluang bagi munculnya pemimpin-pemimpin nasional yang berasal dari bawah dan/atau daerah; (x) pemilihan umum KDH sebagai persiapan untuk karier politik lanjutan; (xi) membangun stabilitas politik dan efektivitas pemerintahan ditingkat lokal serta mencegah separatism; (xii) menciptakan kesetaraan politik (political equality); (xiii) mencegah konsentrasi kekuasaan di pusat; dan (xiv) adanya platform visi misi kepala daerah yang akan menjadi landasan dasar perencanaan di daerah. ${ }^{36}$

Kekurangan Mekanisme ini memiliki beberapa kekurangan antara lain (i) biaya yang relatif besar dalam menyelenggarakan pemilihan umum $\mathrm{KDH}$; (ii) masih banyak terjadi politik uang untuk meningkatkan dukungan; (iii) partisipasi politik masyarakat yang masih minim; (iv) potensi konflik horizontal lebih besar; ( $v$ ) KDH terpilih belum tentu memahami pemerintahan karena mungkin terpilih karena popularitas; (vi) penyalahgunaan wewenang oleh incumbent. ${ }^{37}$

\footnotetext{
32 Momon Soetisna Sendjaja dan Sjachran Basah, Pokok-Pokok Pemerintahan Di Daerah dan Pemerintahan Desa (Bandung: Alumni, 2013), hlm. 7.

33 Sean D. Foreman and Marcia L. Godwin, Local Politics and Mayoral Elections in $21^{\text {st }}$ Century America (New York: Routledge, 2015), hlm. 3-5.

34 Mark Kesselman, Joel Krieger, and William Joseph, Introduction to Comparative Politics: Political Challenges and Changing Agendas (Boston: Cengage Learning, 2015), hlm. 251-252.

35 William Case, Handbook of Southeast Asian Democratization (New York: Routledge, 2014), hlm. 302.

36 Dahlan Thaib, op.cit., hlm. 78.

37 Ari Pradhanawati, Pilkada Langsung Tradisi Baru Demokrasi Lokal (Surakarta: KOMPIP, 2011), hlm. 140.
} 


\section{KEPALA EKSEKUTIF DIANGKAT OLEH DEWAN}

Ketentuan Umum Mekanisme inimerupakan sebuah tren baruyang berkembang di Amerika Serikat. Melaluimekanisme ini, dewan lokal akan mengangkat KDH berdasarkan pengalaman di bidang pemerintahan. Terdapat perbedaan antara pemilihan dan pengangkatan oleh dewan, yakni (i) dalam pemilihan KDH oleh dewan pada umumnya akan dipengaruhi dengan unsur politis yang tinggi sehingga KDH yang dipilih pada umumnya ialah politisi; sedangkan pada pengangkatan maka calon KDH yang diangkat ialah calon yang diharapkan dapat diisi oleh pihak yang memiliki kemampuan di bidang pemerintahan yang mumpuni dan dapat berasal dari luar partai; (ii) dalam pemilihan, pada umumnya dewan akan mengangkat calon $\mathrm{KDH}$ yang berasal dari daerah tersebut saja; sedangkan dalam pengangkatan maka dewan dapat mengangkat calon $\mathrm{KDH}$ yang berasal dari luar daerah tersebut. ${ }^{38}$

Praktik di Negara Di Finlandia, KDH yang diangkat oleh dewan merupakan ketua dewan itu sendiri atau kepala bagian Lain di pemerintahan daerah. Dalam hal KDH tidak dapat melaksanakan tugasnya dengan baik maka harus ada kuorum $3 / 4$ dari dewan yang setuju atas pemecatan $\mathrm{KDH}$ tersebut dan keputusan tersebut harus disampaikan kepada pemerintah provinsi untuk mendapatkan persetujuan. ${ }^{39}$

Di banyak kota di Amerika Serikat, dewan lokal di kota Amerika Serikat akan mengangkat seorang "manajer kota" sebagai KDH. Sebagai KDH, manajer kota tidak hanya menjelaskan dan mempertahankan usulan didepan dewan melainkan juga didepan masyarakat. Adapun usulan manajer kota memiliki peluang untuk ditolak atau bahkan apabila dianggap tidak dapat bekerja dengan baik maka tidak tertutup kemungkinan bahwa manajer kota tersebut dapat dipecat oleh dewan lokal. ${ }^{40}$

Kelebihan

Mekanisme ini memiliki sejumlah kelebihan, antara lain (i) orang yang diangkat oleh KDH merupakan seseorang yang ahli di bidang pemerintahan; dan (ii) minimnya biaya yang dikeluarkan.

Kekurangan

Disamping memiliki kelebihan, mekanisme ini juga memiliki kelemahan antara lain (i) masa jabatan $\mathrm{KDH}$ bergantung pada kondisi perpolitikan di dalam diri dewan lokal sehingga dewan dapat menghendaki pemberhentian atas dirinya kapan saja; (ii) tingginya tingkat pengaruh politik dalam dewan lokal terhadap kebijakan yang diambil oleh $\mathrm{KDH}$; dan (iii) $\mathrm{KDH}$ yang diangkat dewan lokal berpeluang tidak mencerminkan representasi rakyat.

Sumber: Diolah dari Berbagai Sumber

\section{Sistem Pemilihan KDH di Indonesia}

\section{a. Dinamika Sistem Pemilihan KDH dari Masa ke Masa}

Indonesia memiliki sejarah panjang mengenai sistem pemilihan kepala daerah yang terdiri atas beberapa periode yakni (i) pra kemerdekaan; (ii) kemerdekaan; (iii) orde baru; dan (iv) reformasi. Dengan banyaknya pengalaman da- lam mengatur sistem pemilihan kepala daerah ternyata tidak menjamin Pemerintah Indonesia dapat menetapkan mekanisme pemilihan yang lebih baik. Hal ini terbukti dengan adanya kisruh ketika ditetapkan Undang-Undang Nomor

38 Graham Sansom and Peter McKinlay, New Century Local Government: Commonwealth Perspectives (Australia: Commonwealth Secretariat, 2013), hlm. 218.

39 Johannes Kananaen, The Nordic Welfare State in Three Eras: From Emancipation to Discipline (United Kingdom: Ashgate, 2014), hlm. 141.

40 Joseph Bessette and John Pitney, American Government and Politics: Deliberation, Democracy, and Citizenship (Boston: Cengage Learning, 2014), hlm 401-404. 
22 Tahun 2014 tentang Pemilihan Gubernur, Bupati, dan Walikota mengingat rakyat menolak mekanisme pemilihan KDH melalui pemilihan oleh DPRD. Adanya penolakan dari rakyat mengenai mekanisme pemilihan $\mathrm{KDH}$ tersebut maka pemerintah menetapkan Peraturan Pemerintah Pengganti Undang-Undang Nomor 1 Tahun 2014 tentang Pemilihan Gubernur, Bupati, dan Walikota guna mencabut ketentuan sebelumnya. Melalui ketentuan pengganti tersebut maka secara garis besar $\mathrm{KDH}$ akan dipilih langsung oleh rakyat melalui mekanisme pemilihan umum sedangkan wakil $\mathrm{KDH}$ akan diangkat ole Presiden/Menteri sesuai dengan tingkat daerah.

Untuk meminimalisir kisruh akibat kesalahan dalam menetapkan sistem pemilihan kepala daerah dan dapat menetapkan sistem pemilihan kepala daerah yang tepat maka sangat penting bagi regulator untuk memahami gambaran yang utuh mengenai dinamika sistem pemilihan kepala daerah di Indonesia, sebagai berikut.

\section{Tabel 3. Dinamika Sistem Pemilihan KDH dari Masa ke Masa}

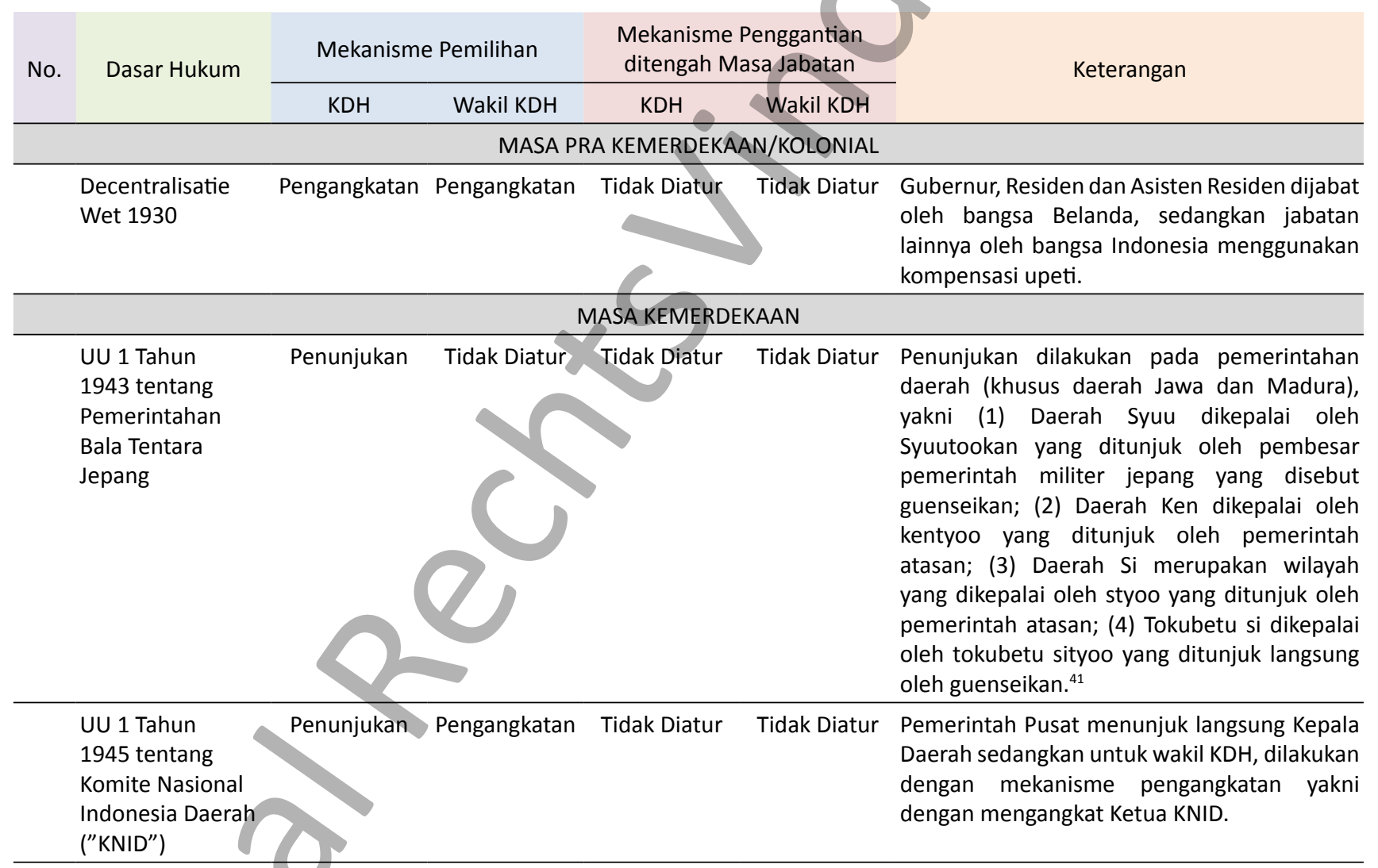

41 Syaukani, Otonomi Daerah dalam Negara Kesatuan (Yogyakarta: Pustaka Relajar, 2011), hlm. 53. 
UU Nomor Pengangkatan Tidak Diatur Penunjukan Tidak Diatur Calon Gubernur diajukan oleh DPRD 22 Tahun

1948 tentang

Pemerintahan di

Daerah

Pengangkatan Tidak Diatur Penunjukan Tidak Diatur

kemudian diangkat oleh Presiden, sementara untuk calon Bupati/Walikota diajukan oleh DPRD kemudian diangkat oleh Menteri Dalam Negeri ("Mendagri"). Akan tetapi, mekanisme pemilihan untuk wakil KDH tidak diatur dalam ketentuan ini. Meskipun demikian, untuk menghindari adanya kekosongan pemangku jabatan KDH jika KDH berhalangan, digunakan mekanisme penunjukan pemangku jabatan sementara oleh Dewan Pemerintah Daerah dengan menunjuk seorang diantara anggotanya untuk mengisi jabatan $\mathrm{KDH} .{ }^{42}$

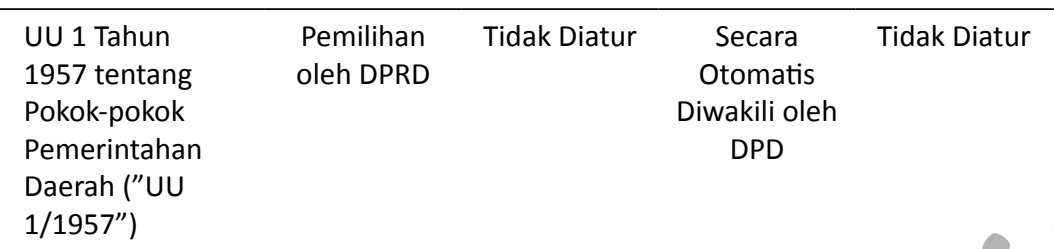

Hasil pemilihan calon Gubernur memerlukan pengesahan lebih dahulu oleh Presiden sedangkan hasil pemilihan calon Bupati/ Walikota memerlukan pengesahan lebih dahulu oleh Mendagri. Adapun mekanisme pengisian wakil KDH tidak diatur dalam ketentuan ini. Lebih lanjut, Pasal 26 mengatur apabila $\mathrm{KDH}$ berhenti/berhalangan dari jabatannya maka, bahwa (i) KDH akan diwakili oleh Wakil Ketua Dewan Pemerintah Daerah ("DPD"); atau (ii) apabila Wakil Ketua DPD juga berhenti/ berhalangan maka akan diwakili oleh anggota yang tertua usianya dari DPD; atau (iii) apabila anggota DPD tersebut berhenti/berhalangan karena suatu keputusan DPRD maka untuk sementara waktu tugas DPD tersebut akan dijalankan oleh Ketua/Wakil Ketua DPRD.

\section{Catatan:}

Wacana sistem pemilihan $\mathrm{KDH}$ secara langsung berdasarkan UU 1/1957 tersebut belum sempat dilaksanakan karena keadaan yang telah menimbulkan keresahan di kalangan Pamong Praja yang bertugas melaksanakan urusan-urusan pemerintah pusat di daerah.
Penetapan Presiden Nomor 6 Tahun 1959 tentang Pemerintah Daerah

\section{Pengangkatan Tidak Diatur}

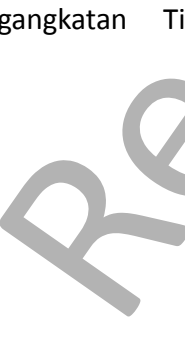

Diatur lebih lanjut oleh Mendagri dan Otonomi Daerah
Tidak Diatur Calon Gubernur akan diangkat oleh Presiden sedangkan calon Bupati/Walikota diangkat oleh Mendagri dan Otonomi Daerah. Dalam ketentuan ini tidak diatur lebih lanjut mengenai mekanisme pengisian wakil $\mathrm{KDH}$. Meskipun demkiian, pada Pasal 5 diatur bahwa Mendagri dan Otonomi Daerah mengatur penentuan penjabat yang mewakili $\mathrm{KDH}$ apabila KDH berhalangan. 
UU Nomor

18 Tahun

1965 tentang

Pokok-Pokok

Pemerintahan

Daerah
Pengangkatan Pengangkatan Pengangkatan Tidak Diatur

$\mathrm{KDH}$ dan wakil $\mathrm{KDH}$ tingkat I akan diangkat oleh Presiden, $\mathrm{KDH}$ dan wakil $\mathrm{KDH}$ tingkat II diangkat oleh Mendagri dengan persetujuan Presiden, dan $\mathrm{KDH}$ dan wakil $\mathrm{KDH}$ tingkat III di dalam daerah tingkat I diangkat oleh $\mathrm{KDH}$ tingkat I dengan persetujuan Mendagri. Adapun pengangkatan tersebut dilakukan terhadap sekurang-kurangnya 2 (dua) dan sebanyak-banyaknya 4 (empat) calon yang diajukan oleh DPRD yang bersangkutan.

Dalam hal $\mathrm{KDH}$ meninggal dunia atau diberhentikan maka wakil KDH akan diangkat sebagai pengganti KDH tersebut hingga akhir masa jabatan, kecuali penguasa menentukan lain.

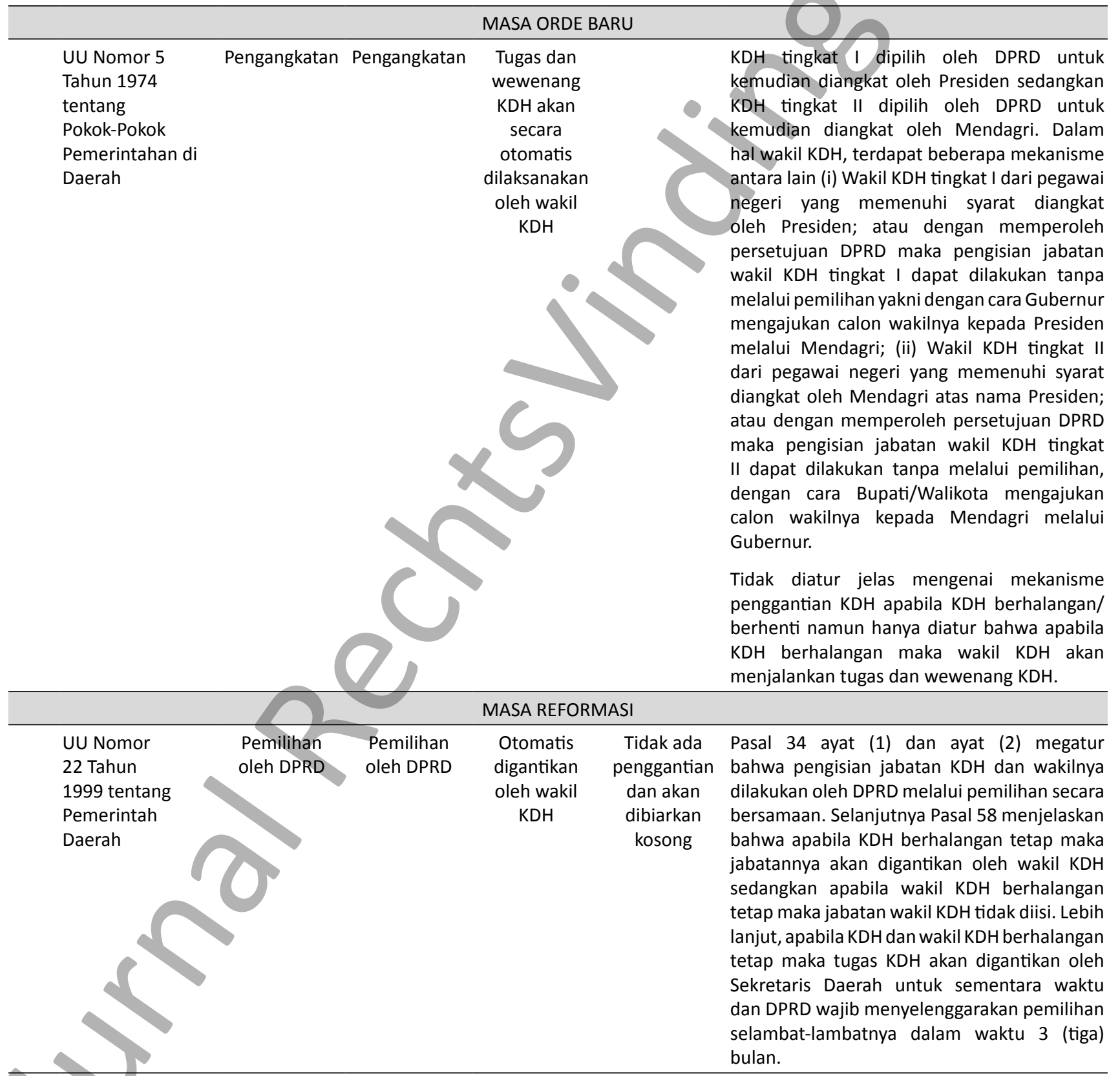




$\begin{array}{lc}\text { UU Nomor } & \text { Pemilihan langsung oleh } \\ \text { 32 Tahun } & \text { rakyat dalam satu pasangan } \\ \text { 2004 tentang } & \text { yang diusulkan oleh partai } \\ \text { Pemerintah } & \text { politik atau gabungan partai } \\ \text { Daerah } & \text { politik }\end{array}$

Diganti oleh Wakil KDH

Pemilihan oleh DPRD

- Apabila KDH diberhentikan sementara karena proses peradilan, wakil $\mathrm{KDH}$ akan melaksanakan tugas dan kewajiban KDH, begitupula apabila wakil KDH diberhentikan sementara maka KDH yang akan melaksanakan tugas dan kewajiban $\mathrm{KDH}$. Selanjutnya, apabila baik KDH dan wakilnya diberhentikan sementara maka Presiden menetapkan pejabat Gubernur atas usul Mendagri atau pejabat Bupati/Walikota atas usul Gubernur dengan pertimbangan DPRD sampai degan adanya putusan yang telah memperoleh hukum tetap.

- Apabila KDH diberhentikan berdasarkan putusan pengadilan yang telah berkekuatan hukum tetap maka jabatan KDH diganti oleh wakilnya hingga masa jabatan habis. Apabila terjadi kekosongan jabatan wakil $\mathrm{KDH}$ diberhentikan berdasarkan putusan pengadilan yang telah berkekuatan hukum tetap dan sisa jabatannya lebih dari 18 (delapan belas) bulan maka KDH akan mengusulkan 2 (dua) orang calon wakil KDH untuk dipilih oleh DPRD.

- Apabila baik KDH dan wakilnya samasama berhenti atau diberhentikan secara bersamaan maka Rapat Paripurna DPRD memutuskan dan menugaskan Komisi Pemilihan Umum Daerah (KPUD) untuk menyelenggarakan pemilihan $\mathrm{KDH}$ dan wakil KDH paling lambat 6 (enam) bulan sejak ditetapkan pemberhentian KDH dan wakilnya. Untuk mencegah kekosongan hukum sebelum digantikan oleh $\mathrm{KDH}$ dan wakil $\mathrm{KDH}$ yang baru maka sekretaris daerah melaksanakan tugas sehari-hari $\mathrm{KDH}$ sampai dengan Presiden mengangkat penjabat KDH dan wakilnya.

\section{UU Nomor} 12 tahun 2008 tentang Perubahan Kedua Atas Undang-Undang Nomor 32 Tahun 2004 tentang Pemerintahan Daerah

\section{Pemilihan langsung oleh rakyat dalam satu pasangan yang diusulkan oleh partai} plitik, gabungan partai politik, atau perseorangan
Diganti oleh Wakil KDH

Pemilihan oleh DPRD
- Pemilihan dilakukan secara demokratis berdasarkan asas langsung, umum, bebas, rahasia, jujur, dan adil.

- Apabila KDH meninggal dunia, berhenti, diberhentikan, atau tidak dapat melakukan kewajibannya selama 6 (enam) bulan secara terus menerus. Dalam hal terjadi kekosongan jabatan wakil KDH maka DPRD akan melakukan pemilihan terhadap calon yang diusulkan oleh $\mathrm{KDH}$. 


$\begin{array}{lccc}\text { UU Nomor 22 } & \text { Pemilihan } & \text { Pemilihan oleh } & \text { Penetapan } \\ \text { Tahun 2014 } & \text { oleh DPRD } & \text { anggota DPRD } & \text { Presiden/ } \\ \text { tentang Pemilihan } & \text { Provinsi } & \text { Kabupaten/ } & \text { Pemilihan } \\ \text { Gubernur, Bupati, } & & \text { Kota } & \text { oleh DPRD } \\ \text { dan Walikota } & & & \end{array}$

Pengangkatan - Gubernur dipilih oleh anggota DPRD oleh Presiden/ Provinsi Sedangkan bupati/walikota dipilih Menteri oleh anggota DPRD Kabupaten/Kota secara demokratis berdasarka asas bebas, terbuka, jujur, dan adil.

- Apabila Gubernur berhenti/diberhentikan yang mana sisa jabatannya kurang dari 18 bulan maka Presiden menetapkan pejabat gubernur atas usul Menteri sampai dengan berakhirnya masa jabatan. Namun apabila sisa jabatan lebih dari 18 bulan maka pemilihan gubernur dilakukan melalui DPRD Provinsi.

Sedangkan apabila bupati/walikota berhenti/diberhentikan yang mana sisa jabatannya kurang dari 18 bulan maka Menteri menetapkan pejabat bupati/ walikota atas usul Gubernur sampai dengan berakhirnya masa jabatan. Namun apabila sisa jabatan lebih dari 18 bulan maka pemilihan bupati/walikota dilakukan melalui DPRD Kabupaten/Kota.

Apabila wakil gubernur berhenti/ diberhentikan maka gubernur mengusulkan calon wakil gubernur kepada Presiden melalui Menteri untuk diangkat, sedangkan apabila wakil bupati/walikota berhenti/ diberhentikan maka bupati/walikota mengusulkan calon wakil bupati/walikota kepada Menteri melalui gubernur.

\section{Catatan:}

Mengingat mekanisme pemilihan $\mathrm{KDH}$ dan wakil $\mathrm{KDH}$ dalam peraturan ini telah mendapatkan penolakan luas dari rakyat dan proses pengambilan keputusannya telah menimbulkan persoalan serta kegentingan yang memaksa sesuai Putusan Mahkamah Konstitusi Nomor 138/PUU-VII/2009, maka ketentuan ini telah dicabut dan dinyatakan tidak berlaku dengan Peraturan Pemerintah Pengganti undang-Undang Nomor 1 Tahun 2014 tentang Pemilihan Gubernur, Bupati, dan Walikota. 


\begin{tabular}{|c|c|c|c|}
\hline $\begin{array}{l}\text { Peraturan } \\
\text { Pemerintah } \\
\text { Pengganti UU } \\
\text { Nomor } 1 \text { Tahun } \\
2014 \text { tentang } \\
\text { Pemilihan } \\
\text { Gubernur, Bupati, } \\
\text { dan Walikota }\end{array}$ & $\begin{array}{c}\text { Pemilihan } \\
\text { langsung oleh } \\
\text { rakyat }\end{array}$ & $\begin{array}{c}\text { Pengangkatan } \\
\text { oleh Presiden/ } \\
\text { Menteri }\end{array}$ & $\begin{array}{c}\text { Penetapan } \\
\text { Presiden/ } \\
\text { Pemilihan } \\
\text { oleh DPRD }\end{array}$ \\
\hline
\end{tabular}

Pengangkatan • KDH akan dipilih melalui pemilihan langsung oleh Presiden/ oleh rakyat melalui penyelenggaraan Menteri Pemilihan Umum Kepala Daerah oleh Komisi Pemilihan Umum Daerah.

- Wakil gubernur akan diangkat oleh Presiden sedangkan wakil bupati/walikota diangkat oleh Menteri berdasarkan usulan bupati/ walikota melalui gubernur.

- Apabila Gubernur berhenti/diberhentikan yang mana sisa jabatannya kurang dari 18 bulan maka Presiden menetapkan pejabat gubernur atas usul Menteri sampai dengan berakhirnya masa jabatan. Namun apabila sisa jabatan lebih dari 18 bulan maka pemilihan gubernur dilakukan melalui DPRD Provinsi.

Sedangkan apabila bupati/walikota berhenti/diberhentikan yang mana sisa jabatannya kurang dari 18 bulan maka Menteri menetapkan pejabat bupati/ walikota atas usul Gubernur sampai dengan berakhirnya masa jabatan. Namun apabila sisa jabatan lebih dari 18 bulan maka pemilihan bupati/walikota dilakukan melalui DPRD Kabupaten/Kota.

- Apabila wakil gubernur berhenti/ diberhentikan maka gubernur mengusulkan calon wakil gubernur kepada Presiden melalui Menteri untuk diangkat, sedangkan apabila wakil bupati/walikota berhenti/ diberhentikan maka bupati/walikota mengusulkan calon wakil bupati/walikota kepada Menteri melalui Gubernur.

Sumber: Diolah dari Berbagai Sumber

\section{b. Sistem Pemilihan KDH Istimewa}

Pada paska kemerdekaan, pengakuan terhadap daerah istimewa di Indonesia berawal dari butir II Penjelasan Pasal 18 UUD 1945 bahwa "daerah istimewa" dibedakan dalam dua kelompok yaitu apa yang disebut dengan zelfbesturende landschappen atau daerah swapraja dan volksgemeenschappen atau desa dan yang setingkat dengan itu. Lebih lanjut, dalam Penjelasan Pasal 18 UUD 1945 tersebut disebutkan secara kongkrit contoh-contoh seperti nagari di Minangkabau dan marga di Palembang. Jika ditilik dari penjelasan UUD 1945 maka pada dasarnya DIY adalah daerah yang memilki keistimewaan sesungguhnya karena daerah otonomi khusus Aceh maupun DKI Jakarta tidak berasal dari kategori daerah istimewa sebagaimana dijelaskan dalam UUD 1945 yang lama.

Paska amandemen UUD 1945 pengaturan mengenai daerah istimewa diatur dalam Pasal 18 B ayat (1) bahwa,"Negara mengakui dan menghormati satuan pemerintahan daerah yang bersifat istimewa yang diatur dengan undang-undang". Dengan ketentuan tersebut, jelaslah untuk saat ini pengaturan sebagaimana disebutkan dalam UUD 1945 pra amandemen sudah tidak berlaku karena sudah dihapus dan digantikan dengan rumusan yang baru. Dengan 
demikian, merujuk pada Pasal 18 B ayat (1), dasar hukum dari sebuah daerah istimewa yang berlaku saat ini adalah ketentuan undangundang. Jika dalam undang-undang ditetapkan sebagai daerah istimewa maka daerah tersebut masuk dalam kategori daerah istimewa.

Meskipun demikian, Presiden Susilo Bambang Yudhoyono saat itu menyatakan bahwa pengisian jabatan di DIY mengingat yang bersifat monarki bertabrakan dengan Pasal 18 ayat (4) UUD 1945 yang mengamanatkan untuk pengisian jabatan dipilih secara demokratis. Pernyataan tersebut seharusnya perlu memperhatikan ketentuan pengisian jabatan DIY tersebut juga perlu memperhatikan ketentuan Pasal 226 ayat (2) UU Nomor 32 Tahun 2004 tentang Pemerintah Daerah ("UU 32/2004") yang mengatur bahwa, "Keistimewaan untuk Provinsi Daerah Istimewa Yogyakarta, sebagaimana dimaksud dalam UU No. 22 Tahun 1999, adalah, tetap dengan ketentuan bahwa penyelenggaraan Provinsi Daerah Istimewa Yogyakarta didasarkan pada UU ini." Adapun ketentuan Pasal 226 ayat (2) UU 32/2004 tersebut sesuai dengan Pasal 18B ayat (1) UUD 1945 untuk tetap mengakui pemerintahan daerah yang bersifat khusus atau istimewa. Meskipun demikian, saat ini kisruh pengisian jabatan di DIY telah berakhir dengan diterbitkannya UU No. 13 Tahun 2012 tentang Keistimewaan DIY yang pada akhirnya menetapkan bahwa pada intinya pengisian jabatan DIY tetap turun temurun.

Dalam konteks pengisian jabatan kepala daerah, kasus DIY sebenarnya menjadi preseden untuk mengingatkan pada persoalan implikasi penerapan kebijakan pengisian pemilihan langsung kepala daerah terhadap mekanisme pengisian jabatan KDH di Daerah Istimewa. Tidak dipungkiribahwa terdapatmekanisme pengisian jabatan KDH yang berbeda di beberapa Daerah Istimewa dan perbedaan tersebut menjadi salah satu bentuk keistimewaan daerah.

SejakUUNo. 22 Tahun 1999, pengaturan KDH di daerah istimewa diatur di ketentuan khusus atas daerah istimewa tersebut kecuali hal-hal yang tidak diatur dalam ketentuan khusus maka akan berlaku peraturan perundang-undangan tentang pemerintah daerah. Lebih lanjut, berdasarkan Pasal 399 Undang Nomor 23 Tahun 2014 tentang Pemerintahann Daerah, terdapat beberapa daerah istimewa yaitu Provinsi Aceh, Provinsi Daerah Khusus Ibukota Jakarta, Provinsi Daerah Istimewa Yogyakarta, Provinsi Papua, dan Provinsi Papua Barat. Secara singkat, dinamika sistem pemilihan $\mathrm{KDH}$ daerah istimewa dapat dilihat pada tabel di bawah ini: 


\begin{tabular}{|c|c|c|c|c|c|c|}
\hline \multirow[t]{2}{*}{ No. } & \multirow[t]{2}{*}{ Dasar Hukum } & \multicolumn{2}{|c|}{ Mekanisme Pemilihan } & \multicolumn{2}{|c|}{$\begin{array}{c}\text { Mekanisme } \\
\text { Penggantian ditengah } \\
\text { Masa Jabatan }\end{array}$} & \multirow[t]{2}{*}{ Keterangan } \\
\hline & & $\mathrm{KDH}$ & Wakil KDH & $\mathrm{KDH}$ & Wakil KDH & \\
\hline \multicolumn{7}{|c|}{ PERATURAN SEBELUM DAERAH ISTIMEWA DIATUR DALAM KETENTUAN KHUSUS } \\
\hline
\end{tabular}

UU Nomor 22 Tahun 1948 Pengangkatan Pengangkatan Tidak Tidak * Wakil KDH di daerah istimewa dapat tentang Pemerintahan di oleh Presiden oleh Diatur Diatur diangkat oleh Presiden dengan syarat Daerah

Presiden* cakap, jujur, setia, dan mempertimbangkan adat istiadat di daerah. Apabila tidak memenuhi, maka wakil KDH adalah anggota Dewan Pemerintah Daerah.

UU 1 Tahun 1957 tentang Pokok-pokok Pemerintahan Daerah
Pengangkatan Pengangkatan Secara oleh Presiden/ oleh Presiden/ Otomatis Mendagri Mendagri Diganti oleh Wakil

$\mathrm{KDH}$
Tidak

Diatur

Apabila KDH berhenti/berhalangan dari jabatannya maka, bahwa (i) $\mathrm{KDH}$ akan diwakili oleh Wakil KDH; atau (ii) apabila Wakil KDH juga berhenti/ berhalangan maka akan diwakili oleh anggota DPD yang dipilih oleh dan dari DPD; atau (iii) apabila dalam daerah istimewa tidak diangkat Wakil KDH maka apabila KDH berhalangan/ berhenti akan diwakili oleh Wakil Ketua DPD; atau (iv) apabila Wakil Ketua DPD tersebut berhenti karena keputusan DPRD maka sementara waktu, tugas Wakil Ketua DPD tersebut akan dijalankan oleh $\mathrm{KDH}$.

Catatan:

Wacana sistem pemilihan KDH secara langsung berdasarkan UU 1/1957 tersebut belum sempat dilaksanakan karena keadaan yang telah menimbulkan keresahan di kalangan Pamong Praja yang bertugas melaksanakan urusan-urusan pemerintah pusat di daerah.

\begin{tabular}{|c|c|c|}
\hline $\begin{array}{l}\text { Penetapan Presiden Nomor } \\
6 \text { Tahun } 1959 \text { tentang }\end{array}$ & $\begin{array}{l}\text { Pengangkatan Pengangkatan } \\
\text { oleh Presiden oleh Presiden }\end{array}$ & $\begin{array}{l}\text { Tidak } \\
\text { Diatur }\end{array}$ \\
\hline
\end{tabular}

oleh Presiden oleh Presiden Diatur

\begin{tabular}{|c|c|c|c|c|c|}
\hline \multicolumn{6}{|c|}{ PROVINSI ACEH } \\
\hline $\begin{array}{l}\text { UU } 18 \text { tahun } 2001 \text { tentang } \\
\text { Otonomi Khusus bagi Provinsi } \\
\text { daerah Istimewa Aceh } \\
\text { Sebagai Provinsi Nangroe } \\
\text { Aceh Darussalam }\end{array}$ & $\begin{array}{c}\text { Pemilihan } \\
\text { langsung oleh } \\
\text { rakyat }\end{array}$ & $\begin{array}{c}\text { Pemilihan } \\
\text { langsung oleh } \\
\text { rakyat }\end{array}$ & $\begin{array}{l}\text { Diatur } \\
\text { dalam } \\
\text { Quanun }\end{array}$ & $\begin{array}{l}\text { Diatur } \\
\text { dalam } \\
\text { Quanun }\end{array}$ & $\begin{array}{l}\text { Pemilihan KDH dan Wakil KDH Provinsi } \\
\text { Nanggroe Aceh Darussalam dilaksanakan } \\
\text { oleh Komisi Independen Pemilihan } \\
\text { ("KIP") dan diawasi oleh Komisi Pengawas } \\
\text { Pemilihan, yang masing-masing dibentuk } \\
\text { oleh Dewan Perwakilan Rakyat Daerah } \\
\text { Provinsi Nanggroe Aceh Darussalam. }\end{array}$ \\
\hline
\end{tabular}

Qanun No. 2 Tahun $2004 \quad$ Pemilihan Pemilihan Pemilihan Pemilihan Pasal 28 ayat (1) mengatur bahwa tentang Pemilihan Gubernur/ langsung oleh langsung oleh langsung langsung selambat-lambatnya 6 (enam) bulan Wakil Gubernur, Bupati/Wakil Bupati Dan Walikota/Wakil rakyat rakyat diberhentikan, atau berhalangan tetap Walikota di Provinsi Nanggroe maka akan dilakukan pemilihan kembali.

Aceh Darussalam

Qanun No. 3 Tahun 2005 tentang Perubahan Atas Qanun No. 2 Tahun 2004 tentang Pemilihan Gubernur/ Wakil Gubernur, Bupati/Wakil Bupati Dan Walikota/Wakil Walikota di Provinsi Nanggroe Aceh Darussalam
Pemilihan Pemilihan Pemilihan Pemilihan Pasal 28 ayat (1) mengatur bahwa langsung oleh langsung oleh langsung langsung selambat-lambatnya 6 (enam) bulan rakyat rakyat oleh oleh segera setelah KDH atau wakilnya berhenti, rakyat rakyat diberhentikan, atau berhalangan tetap maka akan dilakukan pemilihan kembali. 
UU No. 11 Tahun 2006

tentang Pemerintahan Aceh
Pemilihan Pemilihan Digantikan Pemililangsung oleh langsung oleh oleh Wakil han oleh rakyat rakyat

$\mathrm{KDH}$

- Apabila KDH diberhentikan sementara karena proses peradilan, wakil KDH akan melaksanakan tugas dan kewajiban $\mathrm{KDH}$, begitupula apabila wakil $\mathrm{KDH}$ diberhentikan sementara maka $\mathrm{KDH}$ yang akan melaksanakan tugas dan kewajiban KDH. Selanjutnya, apabila baik KDH dan wakilnya diberhentikan sementara maka Presiden menetapkan pejabat Gubernur dengan pertimbangan Dewan Perwakilan Rakyat Daerah Aceh ("DPRA") melalui Mendagri atau pejabat Bupati/Walikota beserta wakilnya dengan pertimbangan Dewan Perwakilan Rakyat Daerah Kabupaten/ Kota ("DPRK") melalui Gubernur sampai dengan adanya putusan yang telah memperoleh hukum tetap.

- Apabila KDH diberhentikan berdasarkan putusan pengadilan yang telah mempunyai kekuatan hukum tetap, jabatan KDH diganti oleh wakil KDH sampai berakhirnya masa jabatan dan proses pelaksanaannya dilakukan berdasarkan keputusan Rapat Paripurna DPRA atau DPRK dan disahkan oleh Presiden.

- Apabila KDH berhenti karena meninggal dunia maka Presiden menetapkan dan mengesahkan wakil KDH untuk mengisi jabatan KDH sampai berakhir masa jabatannya.

- Apabila terjadi kekosongan jabatan wakil $\mathrm{KDH}$ yang sisa masa jabatannya $>18$ bulan maka KDH mengusulkan 2 calon wakil KDH untuk dipilih oleh Rapat Paripurna DPRA/DPRK.

- Apabila baik KDH dan wakilnya diberhentikan secara bersamaan maka Rapat Paripurna DPRA/DPRK memutuskan dan menugaskan KIP untuk menyelenggaraka pemilihan $\mathrm{KDH}$ dan wakilnya paling lambat 6 bulan sejak ditetapkan pemberhentian.

- Dalam hal terjadi kekosongan jabatan KDH maka Sekretaris Daerah Aceh dan Sekertaris Daerah Kabupaten/ Kota melaksanakan tugas KDH sampai Presiden mengangkat KDH.

Qanun No. 7 Tahun 2006 tentang Perubahan Kedua Atas Qanun No. 2 Tahun 2004 tentang Pemilihan Gubernur/ Wakil Gubernur, Bupati/Wakil Bupati Dan Walikota/Wakil Walikota di Provinsi Nanggroe Aceh Darussalam

$\begin{array}{cccclc}\text { Pemilihan } & \text { Pemilihan } & \text { Pemilihan } & \text { Pemilihan } & \text { Pasal } 28 \text { ayat (1) mengatur bahwa } \\ \text { langsung oleh } & \begin{array}{c}\text { langsung oleh } \\ \text { langsung }\end{array} & \text { langsung } & \text { selambat-lambatnya } 5 \text { (enam) bulan } \\ \text { rakyat } & \text { rakyat } & \text { oleh } & \text { oleh } & \text { segera setelah KDH atau wakilnya berhenti, } \\ & \text { rakyat } & \text { rakyat } & \text { diberhentikan, atau berhalangan tetap } \\ & & & & \text { maka akan dilakukan pemilihan kembali. }\end{array}$


$\begin{array}{lcc}\text { Qanun No. } 5 \text { Tahun } 2012 & \text { Pemilihan } & \text { Pemilihan } \\ \text { tentang Pemilihan Gubernur/ } & \text { langsung oleh } & \text { langsung oleh }\end{array}$

Wakil Gubernur, Bupati/Wakil rakyat rakyat

Bupati Dan Walikota/Wakil

Walikota

* Mekanisme pengisian jabatan di tengah masa jabatan tidak diatur dalam qanun ini. Namun demikian, merujuk pada ketentuan Peraturan Pemerintah Nomor 49 Tahun 2008 tentang Perubahan Ketiga Atas Peraturan Pemerintah Nomor 6 Tahun 2005 tentang Pemilihan, Pengesahan Pengangkatan, dan Pemberhentian Kepala Daerah dan Wakil Kepala Daerah yang secara singkat mengatur bahwa apabila KDH berhenti maka wakil KDH yang akan menggantikan dan untuk menggantikan wakil KDH maka akan dipilih dalam Rapat Paripurna DPRD. Apabila baik $\mathrm{KDH}$ dan wakilnya berhenti secara bersamaan maka Rapat Paripurna DPRD memutuskan dan menugaskan KPUD untuk menyelenggarakan pemilihan umum daerah dan selama kekosongan jabatan maka Sekretaris Daerah akan melaksanakan tugas sehari-hari KDH sampai Presiden mengangkat penjabat $\mathrm{KDH}$.

\section{PROVINSI DAERAH KHUSUS IBUKOTA JAKARTA}

UU Nomor 29 Tahun 2007 tentang Pemerintahan Provinsi Daerah Khusus Ibukota Jakarta Sebagai Ibukota Negara Kesatuan Republik Indonesia
- Gubernur dan wakilnya dipilih langsung oleh rakyat.

- Walikota/Bupati wakilnya diangkat oleh Gubernur.
* Oleh karena tidak diatur dalam ketentuan khusus, maka mekanisme pengisian jabatan ditengah masa jabatan akan mengikuti ketentuan dalam Peraturan Pemerintah Pengganti UU Nomor 1 Tahun 2014 tentang Pemilihan Gubernur, Bupati, dan Walikota

\begin{tabular}{|c|c|c|c|}
\hline \multicolumn{4}{|c|}{ PROVINSI DAERAH ISTIMEWA YOGYAKARTA } \\
\hline $\begin{array}{l}\text { UU Nomor } 13 \text { Tahun } 2012 \\
\text { tentang Keistimewaan Daerah } \\
\text { Istimewa Yogyakarta }\end{array}$ & $\begin{array}{c}\text { Penetapan oleh Presiden } \\
\text { berdasarkan usulan DPRD } \\
\text { melalui Menteri }\end{array}$ & $\begin{array}{l}\text { Lihat Bagian } \\
\text { Keterangan }\end{array}$ & $\begin{array}{l}\text { - Apabila KDH berhalangan tetap/ } \\
\text { tidak memenuhi persyaratan lagi } \\
\text { sebagai KDH/diberhentikan sebelum } \\
\text { berakhirnya masa jabatan maka, Wakil } \\
\mathrm{KDH} \text { akan sekaligus melaksanakan tugas } \\
\mathrm{KDH} \text {. Demikian pula apabila Wakil KDH } \\
\text { berhalangan tetap/tidak memenuhi } \\
\text { persyaratan lagi sebagai Wakil KDH/ } \\
\text { diberhentikan sebelum berakhirnya } \\
\text { masa jabatan maka, KDH sekaligus juga } \\
\text { melaksanakan tugas Wakil KDH. } \\
\text { - Apabila baik KDH dan wakilnya } \\
\text { berhalangan tetap/tidak memenuhi } \\
\text { persyaratan lagi sebagai } \mathrm{KDH} / \\
\text { diberhentikan sebelum berakhirnya } \\
\text { masa jabatan maka, Sekretaris Daerah } \\
\text { melaksanakan tugas sehari-hari KDH } \\
\text { sampai Presiden mengangkat penjabat } \\
\mathrm{KDH}\end{array}$ \\
\hline
\end{tabular}




\begin{tabular}{|c|c|c|c|c|}
\hline \multicolumn{5}{|c|}{ PROVINSI PAPUA } \\
\hline $\begin{array}{l}\text { UU No. } 21 \text { Tahun } 2001 \text { ten- } \\
\text { tang Otonomi Khusus Bagi } \\
\text { Provinsi Papua }\end{array}$ & $\begin{array}{c}\text { Pemilihan oleh Dewan } \\
\text { Perwakilan Rakyat Papua } \\
\text { ("DPRP") }\end{array}$ & $\begin{array}{c}\text { Secara } \\
\text { Otomatis } \\
\text { Diganti } \\
\text { oleh Wakil } \\
\text { KDH }\end{array}$ & $\begin{array}{c}\text { Tidak diisi } \\
\text { sampai } \\
\text { habis } \\
\text { masa } \\
\text { jabatan }\end{array}$ & $\begin{array}{l}\text { - Apabila baik KDH dan wakilnya } \\
\text { berhalangan tetap maka DPRP } \\
\text { menunjuk seorang pejabat pemerintah } \\
\text { Provinsi yang memenuhi syarat untuk } \\
\text { melaksanakan tugas-tugas KDH } \\
\text { sampai terpilih KDH terbaru. Apabila } \\
\text { penunjukan belum dilakukan maka } \\
\text { Sekretaris Daerah yang menjalankan } \\
\text { tugas KDH untuk sementara waktu. } \\
\text { - Dalamhal KDHdan wakilnya berhalangan } \\
\text { tetap maka DPRP menyelenggarakan } \\
\text { pemilihan KDH dan wakilnya selambat- } \\
\text { lambatnya dalam waktu } 3 \text { bulan. }\end{array}$ \\
\hline $\begin{array}{l}\text { UU No. } 35 \text { Tahun } 2008 \\
\text { tentang Penetapan Peraturan } \\
\text { Pemerintah Pengganti UU } \\
\text { No. } 1 \text { Tahun } 2008 \text { tentang } \\
\text { Perubahan Atas UU No. } 21 \\
\text { Tahun } 2001 \text { tentang Otonomi } \\
\text { Khusus Bagi Provinsi Papua }\end{array}$ & $\begin{array}{c}\text { Pemilihan langsung oleh } \\
\text { rakyat }\end{array}$ & $\begin{array}{c}\text { Secara } \\
\text { Otomatis } \\
\text { Diganti } \\
\text { oleh Wakil } \\
\text { KDH }\end{array}$ & $\begin{array}{c}\text { Tidak diisi } \\
\text { sampai } \\
\text { habis } \\
\text { masa } \\
\text { jabatan }\end{array}$ & \\
\hline
\end{tabular}

Sumber: Dari Berbagai Sumber

\section{Penutup}

Indonesia adalah negara yang berbentuk Negara Kesatuan (unitry state) dengan kekuasaan asal berada di pemerintah pusat namun kewenangan (authority) pemerintah pusat ditentukan batas-batasnya dalam UUD 1945 atau UU yang ditentukan sebagai kewenangan yang dimiliki oleh pemerintah daerah.

Frasa "dipilih secara demokratis" dalam Pasal 18 ayat (4) UUD 1945 pada dasarnya dapat dimaknai sebagai pemilihan langsung atau pemilihan melalui DPRD, adapun keduanya bersifat konstitusional.

Mekanisme pemilihan $\mathrm{KDH}$ yang pada umumnya dipraktekkan banyak Negara di dunia, yaitu (i) $\mathrm{KDH}$ diangkat oleh pemerintah pusat atau unit yang lebih tinggi; (ii) $\mathrm{KDH}$ dipilih oleh dewan; (iii) KDH dipilih melalui pemilihan umum; dan (iv) KDH diangkat oleh dewan.

Dinamika sistem pemilihan KDH di Indonesia juga tidak terlepas dari sejarah sistem pemilihan $\mathrm{KDH}$. Berbagai perubahan ditandai dengan diberlakukannya berbagai peraturan perundangundangan terkait Pemerintahan Daerah. Dalam konteks sejarah pemilihan $\mathrm{KDH}$, beberapa sistem pemilihan pernah dilaksanakan, (i) pada masa kolonial KDH diangkat oleh pemerintah; (ii) pada masa kemerdekaan KDH diangkat oleh Presiden/Mendagri; (iii) pada masa Orde Baru KDH dipilih oleh DPRD untuk kemudian diangkat oleh Presiden; (iv) pada masa reformasi sistem pemilihan $\mathrm{KDH}$ mengalami beberapa kali perubahan yang diawali dengan pemilihan $\mathrm{KDH}$ oleh DPRD (UU 22/1999), pemilihan umum secara langsung oleh rakyat di daerah yang bersangkutan (UU 32/2004), kembali lagi ke pemilihan KDH oleh DPRD melalui UU 22/2014 namun karena penolakan rakyat akhirnya dicabut dan mekanisme $\mathrm{KDH}$ diganti kembali melalui pemilihan langsung oleh rakyat (Perppu 1/2014). Dengan demikian dapat dikatakan bahwa pemilihan langsung oleh rakyat merupakan mekanisme yang paling didukung oleh rakyat sebagai bentuk demokratis. 
Tidak hanya terjadi di daerah pada umumnya, dinamika pemilihan KDH juga terjadi di daerah istimewa dimana pemilihan $\mathrm{KDH}$ sebelum UU No. 22 Tahun 1999 diatur dalam ketentuan peraturan tentang Pemerintah Daerah. Akan tetapi, sejak keberlakuan UU 22 Tahun 1999 tersebut daerah istimewa diakui keistimewaannya dan mekanisme pemilihan $\mathrm{KDH}$ diatur dalam peraturan daerah istimewa itu sendiri.

Apabila di masa mendatang pemerintah hendak melakukan perubahan terhadap pemilihan $\mathrm{KDH}$ maka disarankan pemerintah memperhatikan aspirasi rakyat terlebih dahulu dan mempelajari kelemahan dan kelebihan dari masing-masing mekanisme pemilihan kepada daerah guna meminimalisir terjadinya kisruh.

\section{DAFTAR PUSTAKA}

Agustino, Leo, Pilkada dan Dinamika Politik Lokal (Yogyakarta: Pustaka Pelajar, 2012).

Andeweg, Rudy B. and Galen A. Irwin, Governance and Politics of the Netherlands (Comparative Government and Politics) (London: Palgrave Macmillan, 2012).

Asshiddiqie, Jimly, Komentar Atas Undang-Undang Dasar Negara Republik Indonesia Tahun 1945 (Jakarta: Sinar Grafika, 2009).

Asshiddiqie, Jimly, Pokok-Pokok Hukum Tata Negara Indonesia Paska Reformasi (Jakarta: PT Bhuana Ilmu Populer, 2012).

Astawa, I Gde Pantja, Problematika Hukum Otonomi Daerah di Indonesia (Jakarta: PT. Alumni, 2012).

Bessette, Joseph and John Pitney, American Government and Politics: Deliberation, Democracy, and Citizenship (Boston: Cengage Learning, 2014).

Bowman, Ann O'M. and Richard C. Kearne, State and Local Government: The Essentials (Boston: Cengage Learning, 2014).

Budisetyowati, Dwi Andayani, Hukum Otonomi Daerah di Negara Kesatuan Republik Indonesia (NKRI) (Jakarta: Roda inti Media, 2013).

Case, William, Handbook of Southeast Asian Democratization (New York: Routledge, 2014).
Cities, United and Local Governments, Decentralization and Local Democracy in The World (Spain: World Bank, 2012).

Coulson, Andrew and Adrian Campbell, Local Government in Central and Eastern Europe: The Rebirth of Local Democracy (New York: Routledge, 2014).

Crook, Richard C and James Manor, Democracry and Decentralisation in South Asia and West Africa: Participation Accountability and Performance (United Kingdom: Cambridge University Press, 2012).

Elder, Neil C. M., Government in Sweden: The Executive at Work (London: Pergamon, 2011).

Foreman, Sean D. and Marcia L. Godwin, Local Politics and Mayoral Elections in $21^{\text {st }}$ Century America (New York: Routledge, 2015).

Gabriel, Oscar W, 'Silke I Keil, EEric Kerrouche, Political Participation in France and Germany (Europe: European Consortium for Political Research, 2012).

Gadjong, Agussalim Andi, Pemerintahan Daerah Kajian Politik dan Hukum Analisis PerundangUndangan Pemerintahan Daerah dan Otonomi Daerah Semenjak Tahun 1945 sampai dengan 2004 (Jakarta: Ghalia Indonesia, 2010).

Handoyo, Hestu Cipto, Hukum Tata Negara, Kewarganegaraan dan Hak Asasi Manusia (Yogyakarta: Universitas Atmajaya Yogyakarta, 2011).

Heinelt, Hubert and Xavier Bertrana, The Second Tier of Local Government in Europe: Provinces, Countries, Departments, and Lankreise in Comparison (New York: Routledge, 2011).

Hoessein, Bhenyamin, Perubahan Model, Pola, dan Bentuk Pemerintahan Daerah: Dari Era Baru ke Era Reformasi (Jakarta: FISIP UI, 2009).

Humes, Samuel and Eileen Martin, The Structure of Local Goverment, A Comparative Survey of 81 Countries (The Hogue: International Union Local Authority, 2011).

Istianto, F. Sugeng, Beberapa Segi Hukum Pemerintahan Pusat dan Daerah dalam NKRI (Karya Putera: Yogyakarta, 2010).

Kananaen, Johannes, The Nordic Welfare State in Three Eras: From Emancipation to Discipline (United Kingdom: Ashgate, 2014).

Kesselman, Mark Joel Krieger, and William Joseph, Introduction to Comparative Politics: Political Challenges and Changing Agendas (Boston: Cengage Learning, 2015). 
Kincaid, John and Nico Steytler, Local Government and Metropolitan Regions in Federal Countries (Canada: McGill-Queen's University Press, 2012).

Loughlin, John, Frank Hendriks, and Anders Lidström, The Oxford Handbook of Local and Regional Democracy in Europe (Oxford: Oxford University Press, 2011).

Marbun, Otonomi Daerah 1945-2005 Proses dan Realita, Perkembangan Otonomi Daerah Sejak Zaman Kolonial Sampai Saat Ini (Jakarta: Pustaka Sinar Harapan, 2011).

Miller, David $Y$ and Raymond Cox, Governing the Metropolitan Region: America's New Frontier (United States: Taylor \& Francis, 2014).

MD, Mahfud, Perdebatan Hukum Tata Negara Paca Amandemen Konstitusi (Jakarta: LP3ES, 2007).

Öjendal, Joakim and Anki Dellnäs, The Imperative of Good Local Governance: Challenges for the Next Decade of Decentralization (United States: United Nations University Press, 2013).

Oliver, J. Eric, Shang E. Ha, and Zachary Callen, Local Elections and the Politics of Small-Scale Democracy, (United Kingdom: Princeton University Press, 2012).

Pradhanawati, Ari, Pilkada Langsung Tradisi Baru Demokrasi Lokal (Surakarta: KOMPIP, 2011).
Sansom, Graham and Peter McKinlay, New Century Local Government: Commonwealth Perspectives (Australia: Commonwealth Secretariat, 2013).

Sarundajang, Pemerintahan Daerah di Berbagai Negara, Tinjauan Khusus Pemerintahan Daerah di Indonesia: Perkembangan Kondisi dan Tantangan (Jakarta: Sinar Harapan, 2012).

Sendjaja, Momon Soetisna dan Sjachran Basah, Pokok-Pokok Pemerintahan Di Daerah dan Pemerintahan Desa (Bandung: Alumni, 2013).

Siddiquee, Noore Alam, Public Management and Governance in Malaysia: Trends and Transformations (New York: Routledge, 2012).

Soemantri, Sri, Prosedur dan Sistem Perubahan Konstitusi (Bandung: Alumni, 2011).

Syaukani, Otonomi Daerah dalam Negara Kesatuan (Yogyakarta: Pustaka Relajar, 2011).

Thaib, Dahlan, Ketatanegaraan Indonesia Perspektif Konstitusional (Yogyakarta: Penerbit Total Media, 2011).

Thomas, David M. and David N. Biette, Canada and The United States: Differences That Count (Canada: University of Toronto Press, 2014).

Wastiono, Sadu, Memahami Asas Tugas Pembantuan (Bandung: Fokus Media, 2011). 
"Halaman ini dikosongkan" 


\title{
DINAMIKA HUKUM PEMILIHAN KEPALA DAERAH MENUJU PROSES DEMOKRASI DALAM OTONOMI DAERAH
}

\author{
(Dynamic Process on the Law of Local Election for Regional Leaders \\ Toward Democratic Way in Regional Autonomy)
}

\author{
Diana Yusyanti \\ Pusat Penelitian dan Pengembangan Sistem Hukum Nasional \\ Badan Pembinaan Hukum Nasional \\ Jl. Mayjen Sutoyo 10 Cililitan Jakarta \\ Email: diana_yusyanti@yahoo.co.id ; deon.zus@gmail.com \\ Naskah diterima: 20 Februari 2015 ; revisi: 24 April; disetujui: 30 April 2015
}

\begin{abstract}
Abstrak
Dinamika hukum pemilihan Kepala diawali pada masa orde baru dengan model demokrasi perwakilan (DPRD) yang dilaksanakan berdasarkan Undang-Undang Nomor 5 Tahun 1974. Pada masa orde baru pemerintahan Daerah lebih bersifat sentralistik, sehingga demokrasi tidak berkembang. Pada masa reformasi, Kepala Daerah dan Wakil Kepala Daerah dipilih secara langsung yang mulanya diatur oleh Undang-Undang Nomor 22 Tahun 1999 sebagai awal Otonomi Daerah diberlakukan secara luas, kemudian diteruskan dengan Undang-Undang Nomor 32 Tahun 2004 sehingga Otonomi Daerah menjadi desentralistik dan demokrasipun mulai berkembang meskipun dalam pelaksanaan pemilihan Kepala Daerah masih banyak terjadi konflik di beberapa daerah. Pada saat ini sudah ada Undang-Undang yang terbaru yaitu UndangUndang 23 Tahun 2014 dimana Kepala Daerah dipilih secara langsung tapi tidak satu paket dengan Wakil Kepala Daerah yang dipilih oleh Kepala Daerah. Dengan metode yuridis normatif, penulis akan menguraikan dinamika pemilihan Kepala Daerah sebelum maupun sesudah diberlakukannya Undang-undang Nomor 32 Tahun 2004 dan mengapa banyak terjadi konflik. Pada prinsipnya Pemilihan Kepala Daerah secara langsung merupakan jalan masuk bagi demokrasi politik di daerah dan memberikan kesempatan kepada rakyat memilih pimpinan daerah secara objektif. Dengan perbaikan pada penyelenggaraan pemilihan Kepala Daerah dan perlunya pendekatan sosial, budaya politik dan budaya hukum yang bertujuan untuk mengurangi konflik yang seringkali terjadi.
\end{abstract}

Kata kunci: Pilkada-Demokrasi-Otonomi Daerah

\begin{abstract}
Dynamic of law on local election for regional leaders began in the 'Orde Baru' era with the model of representative democracy (parliament) which was implemented by Law No. 5 of 1974. In the 'Orde Baru' era, Regional government is more centralized, so that the democracy did not thrive. In the Reform Era, the electoral system for regional leaders and vice of regional leaders changed to direct election according to Law No. 22 of 1999 as the beginning of the Regional Autonomy System widely implemented, and continued with the Law No. 32 of 2004 so the Regional Autonomy System become decentralized and that democracy began to flourish despite there are still a lot of conflicts in some areas refering to the implementation of the local election for regional leaders. Now there is Law No. 23 of 2014 which said that Regional Leaders are elected directly but not as a single package with vice of regional leaders whom they will be chosen by the Regional Leaders itself. Using a normative juridical approach the writer would like to elaborate the dynamic process in the electoral system of regional leaders before and after the implementation of Law No.32 of 2004 and why there are some conflicts. It can be said that the direct local election of regional leaders is an entry point for democracy politics in regions and it also gives people a chance to vote their own leader. The improvement in the conduct of local election for regional leaders and the approach in social, cultural politics and legal culture are needed in order to reduce conflicts in some areas. Keywords: election, democracy, regional autonomy
\end{abstract}




\section{A. Pendahuluan}

Sebagaimana diamanatkan dalam Pasal 18 ayat (1) Undang-Undang Dasar Negara Republik Indonesia Tahun 1945, bahwa Negara Kesatuan Republik Indonesia dibagi atas daerah-daerah provinsi dan daerah provinsi itu dibagi atas kabupaten dan kota, yang tiap-tiap provinsi, kabupaten, dan kota itu mempunyai pemerintahan daerah, yang diatur dengan undang-undang. Sedangkan pada ayat (2) menyebutkan bahwa Pemerintahan daerah provinsi, daerah kabupaten, dan kota mengatur dan mengurus sendiri urusan pemerintahan menurut asas otonomi dan tugas pembantuan.

Berdasarkan Undang-Undang Nomor 32 tahun 2004 tentang Pemerintahan Daerah ${ }^{1}$, pengertian otonomi daerah adalah wewenang daerah untuk mengatur dan mengurus sendiri urusan pemerintahan dan kepentingan masyarakat setempat sesuai dengan peraturan perundang-undangan. Otonomi daerah diperlukan agar urusan pemerintahan dapat diselenggarakan dengan baik melalui pelimpahan wewenang kepada pemerintah daerah dalam berbagai bidang. Dengan wewenang yang dimilikinya, pemerintah daerah akan dapat merumuskan dan melaksanakan kebijakan yang sesuai dengan kebutuhan daerahnya. Otonomi Daerah merupakan terobosan untuk memperkuat Indonesia sebagai sebuah bangsa dengan mengakomodasi keragaman daerah. Kebijakan desentralisasi dan otonomi daerah telah menimbulkan dinamika di daerah, seperti dinamika dibidang ekonomi, sosial dan budaya terutama dinamika perilaku politik.
Berkaitan dengan dinamika perilaku politik di daerah, berdasarkan hasil Lembaga Survey Indonesia (LSI), ${ }^{2}$ menyebutkan bahwa, dilihat dari sikap dan perilaku politik warga, otonomi daerah yang sudah berjalan sampai hari ini belum mampu menjembatani kedaerahan dan keindonesiaan. Namun demikian, tidak terkaitnya secara berarti antara otonomi daerah dan ke Indonesiaan masih tertolong berkat demokrasi. Bila demokrasi melemah, terutama dilihat dari kinerjanya, maka Otonomi Daerah bukan memperkuat NKRI melainkan memperlemahnya.

Menurut Philip Mawhood dan J.A. Chandler dalam Suharizal, ${ }^{3}$ pemerintah lokal memiliki potensi dalam mewujudkan demokratisasi karena proses desentralisasi mensyaratkan adanya tingkat responsivitas, keterwakilan dan akuntabilitas yang lebih besar. Dalam kaitannya dengan Pemilihan Kepala Daerah mengutip pendapat Allan R.Ball, pemilu dan demokrasi berkaitan erat dalam substansi maupun fungsi. Pemilu merupakan aktualisasi nyata demokrasi dalam praktek bernegara masa kini karena menjadi sarana utama bagi rakyat untuk menyatakan kedaulatannya atas negara dan pemerintahan. Pernyataan kedaulatan rakyat diwujudkan dalam proses pelibatan masyarakat untuk menentukan siapa-siapa yang harus menjalankan pemerintahan khususnya di daerah.

Pemerintah pusat pada era pemerintahan Susilo Bambang Yudoyono telah memberikan kewenangan kepada Pemerintah Daerah. Salah satunya yaitu kewenangan bagi Kepala Daerah dan Pemerintah Daerah diatur dengan

Undang-Undang Nomor 32 Tahun 2004 tentang Pemerintahan Daerah, LN 2004, TLN 4437.

http://www.lsi.or.id/riset/202/keindonesiaan-kedaerahan-dan-demokrasi (diakses pada 8 Fabruari 2015).

Suharizal, Pilkada, Regulasi, Dinamika dan Konsep Mendatang, (Jakarta: RajaGrafindo, 2011) hlm. 175. 
Undang-Undang Nomor 32 Tahun 2004 tentang Pemerintah Daerah yang memberikan kewenangan untuk mengadakan Pemilihan Kepala Daerah. Dalam Pasal 56 Undang-Undang Nomor 32 Tahun 2004 tersebut dikatakan bahwa Kepala Daerah dan Wakil Kepala Daerah dipilih dalam satu pasangan calon yang dilaksanakan secara demokratis berdasarkan asas langsung, umum, bebas, rahasia, jujur dan adil. Selain itu di dalam Undang-Undang Nomor 32 Tahun 2004 diatur juga mengenai pemilihan Kepala Daerah dan Wakil Depala daerah yang dipilih secara langsung oleh rakyat, yang diajukan oleh partai politik atau gabungan parpol.

Sedangkan Di dalam perubahan UndangUndang Nomor 32 Tahun 2004 sebagaimana telah diubah dengan Undang-Undang Nomor 12 Tahun 2008 tentang Pemerintahan Daerah, dalam Pasal 59 ayat $1 \mathrm{~b}$ disebutkan bahwa calon Kepala Daerah dapat juga diajukan dari calon perseorangan yang didukung oleh sejumlah orang. Sedangkan dalam undang-undang terbaru yang mengatur tentang pemerintahan daerah, yaitu Undang-Undang Nomor 23 Tahun 2014 tentang Pemerintah Daerah, disebutkan dalam Pasal 65 ayat 1 bahwa Wakil Kepala Daerah tidak lagi dipilih secara paket bersama Kepala Daerah. Pada Pasal 65 ayat 2 UndangUndang No. 23 Tahun 2014 ini juga menyatakan memberi wewenang kepada Kepala Daerah untuk mengambil kebijakan khusus apabila terjadi kondisi darurat di daerah.

Berkaitan dengan masalah pemilihan kepala daerah, seperti diketahui pada akhir tahun 2014 yang baru saja lewat berbagai polemik tentang Pemilihan Kepala Daerah pada saat itu begitu menyeruak ke ranah publik dan cukup menyita perhatian yaitu tentang Pemilihan Kepala Daerah langsung atau melalui DPRD. Hal ini terjadi sebagai lanjutan euforia dari Pemilihan
Presiden (PILPRES) yang masih melekat sehingga menimbulkan terjadinya dua kubu yaitu kubu Koalisi Indonesia Hebat (KIH) dan Koalisi Merah Putih (KMP). Pertentangan antara $\mathrm{KIH}$ dengan KMP tersebut pada akhirnya berimbas pada pro dan kontra pelaksanaan pemilihan kepala daerah secara langsung maupun pemilihan kepala daerah melalui DPRD. Kontroversi pemilihan kepala daerah yang berkepanjangan tersebut tidak saja terjadi pada perdebatan para politisi yang berdebat sebagaimana ditayangankan di televisi, juga terjadi polemik pro kontra pada masyarakat melalui sosial media.

MelihathaltersebutPresiden SusiloBambang Yudhoyono pada sekitar bulan Oktober Tahun 2014 menerbitkan dua Peraturan Pemerintah Pengganti Undang-Undang yaitu Perppu Nomor 1 Tahun 2014 tentang perubahan atas UndangUndang Nomor 22 Tahun 2014 tentang Pemilihan Kepala Daerah (Pemilihan Gubernur, Bupati dan Walikota) beserta penjelasannya. Disusul kemudian yang kedua Perppu Nomor 2 Tahun 2014 tentang Perubahan atas Undang-Undang Nomor 23 Tahun 2014 tentang Pemerintahan Daerah beserta penjelasannya. Masingmasing Perppu tersebut untuk mencabut dan atau menambah beberapa ketentuan dalam Undang-Undang Nomor 22 Tahun 2014 dan juga Undang-Undang Nomor 23 Tahun 2014 tentang Pemerintahan Daerah (terutama mencabut ketentuan yang memberi kewenangan kepada DPRD untuk memilih Kepala Daerah). Akan tetapi Perppu yang dikeluarkan oleh Presiden SBY inipun ternyata tidak mendapat dukungan luas dari sebagian masyarakat, sehingga pro dan kontra masih terus terjadi.

Setelah terjadi tarik ulur maupun perdebatan yang panjang akhirnya pada sekitar bulan Januari Tahun 2015, Perppu No.1 Tahun 2014 mengenai perubahan atas Undang-Undang 
Nomor 22 Tahun 2014 tentang Pemilihan Gubernur, Bupati, dan Walikota, serta Perppu Nomor 2 Tahun 2014 mengenai perubahan atas Undang-Undang No. 23 Tahun 2014 tentang Pemerintahan Daerah, dapat disahkan menjadi undang-undang, yaitu Undang Undang Nomor 1 Tahun 2015 tentang Penetapan Peraturan Pemerintah Pengganti Undang-Undang Nomor 1 Tahun 2014 tentang Pemilihan Gubernur, Bupati dan Walikota. Sedangkan Perppu Nomor 2 Tahun 2014 mengenai perubahan atas Undang-Undang Nomor 23 Tahun 2014 tentang Pemerintahan Daerah masih dalam proses perbaikan dan akan menjadi undang-undang.

Pada mekanisme pemilihan kepala daerah melalui DPRD dilihat dari sisi ruang partisipasi rakyat untuk memilih maka pemilihan Gubernur melalui DPRD memiliki derajat ruang partisipasi rakyat untuk memilih lebih rendah jika dibandingkan dengan sistem pemilihan kepala daerah secara langsung. Selain itu, hal tersebut menimbulkan kerancuan sistem pemerintahan, apakah Indonesia menganut sistem presidensil atau parlementer. Pelaksanaan pemilihan Kepala Daerah lewat DPRD juga berpotensi mengancam kinerja kepala daerah karena DPRD akan mempunyai posisi lebih tinggi dibanding kepala daerah

Melihat hal-hal tersebut diatas, penulis tertarik membahas topik Dinamika Hukum Pemilihan Kepala Daerah menuju Proses Demokrasi Dalam Otonomi Daerah. Pemilihan kepala daerah sebelum maupun sesudah diberlakukannya Undang-Undang Nomor 32 Tahun 2004 tentang Pemerintahan Daerah, telah banyak menimbulkan masalah. Adanya konflik sebelum maupun setelah pemilihan kepala daerah seperti isu mengenai adanya money politik, kecurangan dalam bentuk penggelembungan suara, kampanye hitam, bahkan terjadinya benturan fisik antara dua kelompok masyarakat pendukung calon kepala daerah sebelum maupun setelah penentuan pemenangan. Bahkan setelah terpilihnya kepala daerah, hubungan antara kepala daerah dengan wakil kepala sering tidak harmonis karena tidak cocok dalam pengambilan kebijakan dan atau sebab lainnya.

Berdasarkan latar belakang tersebut dalam kesempatan ini penulis ingin mengkaji, bagaimana dinamika hukum pemilihan Kepala Daerah menuju proses demokrasi dalam otonomi daerah? bagaimana model pemilihan Kepala Daerah yang lebih cocok untuk diterapkan pada otonomi daerah dalam kerangka demokrasi yang sehat? Faktor-faktor apa yang menyebabkan penyelenggaraan pemilihan kepala daerah secara langsung, banyak menimbulkan konflik?

\section{B. Metode Penelitian}

Metode penelitian yang digunakan dalam penulisan ini adalah menggunakan metode penelitian hukum normatif. ${ }^{4}$ Menurut Soerjono 
dan $\mathrm{H}$. Abdurahman ${ }^{5}$ yaitu penelitian yang dilakukan dengan cara mengkaji peraturan perundang-undangan yang berlaku atau diterapkan terhadap suatu permasalahan hukum tertentu. Penelitian normatif seringkali disebut dengan penelitian doktrinal, yaitu penelitian yang objek kajiannya adalah dokumen Perundang-Undangan dan bahan pustaka.

Teknik pengumpulan data dilakukan melalui studi kepustakaan (data sekunder). Sumber Data/ Bahan Hukum. Data sekunder adalah data yang diperoleh dari penelitian kepustakaan dan dokumen, yang merupakan hasil penelitian dan pengolahan orang lain, yang sudah tersedia dalam bentuk buku-buku atau dokumen yang biasanya disediakan di perpustakaan, atau milik pribadi. $^{6}$

Data sekunder diperoleh melalui bahan primer, bahan hukum sekunder, dan bahan hukum tertier. Bahan hukum primer yaitu bahan-bahan hukum yang mengikat dan terdiri dari UUD 1945; Peraturan perundang-undangan tentang Pemerintahan Daerah dan Peraturan tentang Pemilihan Kepala Daerah dari mulai setelah kemerdekaan yang hingga saat ini. Sedangkan bahan sekunder, yaitu bahan-bahan yang erat hubungannya dengan bahan hukum primer dan dapat membantu menganalisis dan memahami bahan hukum primer $^{7}$ diperoleh dari buku-buku, jurnal hasil penelitian. Sedangkan Bahan hukum tertier ${ }^{8}$, yaitu bahan-bahan yang memberikan informasi tentang bahan hukum primer dan bahan hukum sekunder berkaitan dengan masalah otonomi daerah maupun pemilihan kepala daerah. Kemudian data tersebut diinventarisir dan diklasifikasikan serta disusun secara komperhensif. dilakukan melalui penelusuran manual maupun elektronik.

\section{Pembahasan}

1. Dinamika Hukum Pemilihan Kepala Daerah Menuju Proses Demokrasi Dalam Otonomi Daerah
a. Pemilihan Kepala Daerah Sejak Kemerdekaan sampai dengan pemerintahan Orde Baru.

Sejak kemerdekaan, ketentuan mengenai Pemerintahan Daerah (termasuk didalamnya mekanisme pemilihan kepala daerah) diatur dalam sejumlah Undang-Undang, yaitu mulai Undang-Undang Nomor 1 Tahun 1945 tentang Kedudukan Komite Nasional Daerah, UndangUndang Nomor 22 Tahun 1948 tentang Pemerintahan Daerah, Undang-Undang Nomor 1 Tahun 1957 tentang Pokok-Pokok Pemerintahan Daerah, Undang-Undang Nomor 18 Tahun 1965 tentang Pokok-Pokok Pemerintahan Daerah kemudian Undang-Undang Nomor 5 Tahun 1974 tentang Pokok-Pokok Pemerintahan di daerah.

Berdasarkan Undang-Undang Nomor 1 Tahun 1945, pemilihan Kepala Daerah dilakukan oleh Dewan. Sementara menurut Undang-Undang Nomor 22 Tahun 1948 tentang Pemerintahan Daerah, pada Undang-Undang tersebut Kepala Daerah dipilih oleh Pemerintah Pusat dari calon-calon yang diajukan oleh DPRD.

Soerjono dan H.Abdurahman, Metode Penelitian Hukum, (Jakarta, Rineke Cipta; 2003, hlm 56).

6 Hilman Hadikusuma, Metode Pembuatan Kertas Kerja atau Skripsi Ilmu Hukum, Mandar Maju, ( Bandung, 1995, hlm.65.)

7 Ronny Hanitjo Soemitro, Metodologi Penelitian Hukum dan Jurimetri, Cetakan Kelima, GhaliaIndonesia, ( Jakarta, 1994 ) hlm. 12

$8 \quad$ Ibid hlm 12 
DPRD berhak mengusulkan pemberhentian seorang Kepala Daerah kepada Pemerintah Pusat.

Di era pemerintahan orde Baru pemilihan Kepala Daerah tidak terlepas dari intervensi elit di pusat. Pada Pasal 15 Undang-Undang Nomor 5 Tahun 1974 tentang Pokok-Pokok Pemerintahan Daerah, beberapa calon Kepala Daerah dipilih oleh DPRD, akan tetapi selanjutnya diajukan kepada pejabat pemerintah di angkat sebagai Kepala Daerah, dengan kata lain Bupati/ Walikota dipilih oleh Mendagri, dan Gubernur dipilih oleh Presiden. DPRD tidak mempunyai kewenangan untuk menentukan siapa yang harus jadi Kepala Daerah. DPRD hanya pelaksana dari keinginan Pemerintah Pusat, karena kewenangan dan hak yang menentukan siapa Kepala Daerah adalah Pemerintah Pusat. Dengan mekanisme pemilihan Kepala Daerah menjadi bersifat sentralistik bahkan otoriter, karena mekanisme kebijakan dan pembuatan keputusan hanya diputuskan oleh seorang pemimpin walaupun ada lembaga perwakilan rakyat. DPRD pada waktu itu tidak bekerja efektif seperti yang terjadi saat ini. Lembaga perwakilan rakyat seperti "tidak mempunyai kedaulatan rakyat" karena selalu setuju apapun kebijakan pemerintah dari pusat khususnya tentang penunjukan yang akan menjadi kepala daerah.

Hal tersebut bertolak belakang dengan teori kedaulatan di mana dalam teori ini dinyatakan bahwa: "Kedaulatan tertinggi ada di tangan rakyat, karena pada dasarnya dalam menjalankan roda pemerintahan, pemerintah harus berpijak pada kehendak rakyat". Intiajaran dari teori kedaulatan rakyat adalah pertama, kedaulatan tertinggi berada di tangan rakyat (teori ajaran demokrasi) dan kedua, adanya jaminan konstitusi terhadap hak asasi manusia. Teori ini juga memandang dan memaknai bahwa kekuasaan itu berasal dari rakyat, sehingga dalam melaksanakan tugasnya pemerintah harus berpegang pada kehendak rakyat yang lazimnya disebut dengan demokrasi. Rakyatlah penentu akhir penyelenggaraan kekuasaan dalam suatu negara ${ }^{9}$

Indonesia merupakan negara yang mendasarkan kedaulatannya atas dasar kedaulatan rakyat disamping atas dasar kedaulatan hukum. Hal ini dapat dilihat pada ketentuan Pasal 1 ayat (2) UUD NRI Tahun 1945 sebelum perubahan, "Kedaulatan ialah di tangan rakyat dan dilakukan sepenuhnya oleh Majelis Permusyawaratan Rakyat" dan bandingkan dengan Pasal 1 ayat (2) UUD NRI Tahun 1945 setelah perubahan "Kedaulatan berada di tangan rakyat dan dilaksanakan menurut Undang-Undang Dasar".

Kewenangan yang diberikan pemerintah pusat kepada pemerintah daerah dengan sistem dan prinsip Negara Kesatuan Republik Indonesia, sebagaimana dimaksud dalam Undang-Undang Dasar Negara Republik Indonesia (UUD 1945). Di sana di atur dan ditetapkan bahwa Pemerintah Pusat sebagai penyelenggara Negara Kesatuan Republik Indonesia berdasarkan Pancasila dan Undang Undang Dasar 1945, yaitu Pasal 1 ayat (2) UUD 1945 yaitu kedaulatan berada di tangan rakyat.

Eddy Purnama, Negara Kedaulatan Rakyat:Analisis Terhadap Sistem Pemerintahan Indonesia dan Pebandingannya dengan Negara Lain. ( Bandung, Nusamedia, 2007), hlm 9. 
Kedaulatan Rakyat menurut teori Jean Bodin $^{10}$ bahwa kekuasaan mutlak dan tertinggi merupakan hal yang penting bagi sebuah negara dalam rangka mengatur seluruh warga negara maupun orang-orang lain di dalam ruang lingkup wilayahnya. Namun demikian berkaitan dengan kekuasaan yang dimiliki penguasa yang karena diperoleh dalam kurun waktu tertentu, maka kekuasaan tertinggi itu tidak dapat disebut sebagai kedaulatan. Penguasa hanyalah sebuah alat untuk melaksanakan kehendak dari pihak yang memberikan kekuasaan terhadapnya.

Jika dikaitkan pada jaman orde baru maka pemerintahan orde baru pada prakteknya bertentangan dengan Pasal 1 ayat (2) UUD NRI Tahun 1945 (sebelum amandemen) yaitu Kedaulatan ialah di tangan rakyat dan dilakukan sepenuhnya oleh Majelis Permusyawaratan Rakyat (MPR). Pada kenyataannya tidak ada kedaulatan rakyat yang sepenuhnya dilakukan oleh MPR, karena pada prakteknya MPR juga menurut apa kata petunjuk bapak Presiden. Seperti sering dikatakan Harmoko waktu menjabat sebagai Menteri Penerangan Republik Indonesia pada masa Orde Baru, dan Ketua MPR pada masa pemerintahan BJ Habibie, selalu berulang-ulang di media televisi mengucapkan "menurut petunjuk bapak Presiden", bukan menurut undang-undang, padahal Indonesia adalah negara hukum.

Banyak teori yang dipakai sejak UndangUndang Nomor 1 Tahun 1945 sampai 1974, sistem otonomi daerah dikonsepsikan sebagai otonomi materiil, otonomi formal dan otonomi yang nyata dan bertanggung jawab; otonomi yang nyata, serasi, dinamis dan bertanggung jawab; sampai kepada otonomi luas, nyata dan bertanggung jawab, sebagai kerangka berpikir untuk memaknai dan mewujudkan amanat Pasal 18 UUD 1945. Namun sejak Indonesia merdeka sampai berakhirnya kekuasaan Presiden Soeharto pada Tahun 1998, cita-cita desentralisasi dan otonomi daerah tidak pernah bisa diwujudkan. Ketika sistem pemerintahan otoriter yang sentralistik runtuh bersamaan dengan mundurnya Soeharto pada 21 Mei 1998, sejumlah daerah yang merasa diperlakukan tidak adil oleh pemerintah pusat menuntut dan melakukan gerakan untuk memisahkan diri dari Negara Kesatuan Republik Indonesia. ${ }^{11}$

Sejumlah daerah yang merasa diperlakukan tidak adil kemungkinan dikarenakan sampai dengan pemilihan kepala daerah pun pada masa orde baru yang dimenangkan untuk menjadi kepala daerah didominasi oleh calon dari Golongan Karya (GOLKAR) setelah itu baru dari ABRI, bukan diprioritaskan dari putera daerah setempat, sehingga akhirnya banyak kepala daerah yang tidak mengerti secara details seluk beluk daerah yang dipimpinnya. Ketidakpuasan timbul akibat pengendalian pemerintah pusat terhadap penghasilan dari sumber daya alam di daerah, sebagian besar dikuasai pemerintah pusat. Selain juga kurang sensitifnya pemerintah dalam memberikan perhatian pembangunan infrastruktur untuk mengelola sumber daya alam antar daerah yang tidak merata sehingga menimbulkan ketidak puasan dari beberapa daerah yang pada akhirnya kemudian memunculkan permintaan yang kuat akan pembagian kekuasaan bahkan ada yang mempunyai keinginan untuk memisahkan

\footnotetext{
10 Jean Bodin, Six Books Of Commonwealth Blackwell's political texts, (Michingan University : B. Blackwell, 1995) hlm.70.

11 Syamsuddin Haris dkk, Indonesia d Ambang Perpecahan?,( Jakarta: Erlangga , 1999) hlm. 3.
} 
diri dari Indonesia. Pemerintah era orde baru kurang responsif terhadap keinginan atau aspirasi masyarakat di daerah. Pemerintah Orde baru me-manage daerah sangat sentralistik dan tidak memberikan peluang bagi kemunculan proses demokrasi yang sehat pada masyarakat, kebijakan yang dibuat sepertinya otoriter.

Menurut Daniel Darkhidae yang dikutip Ni'matul Huda, ${ }^{12}$ selama era pemerintahan orde baru berlangsung, tidak ada yang namanya perimbangan keuangan antara pusat dan daerah. Daerah penghasil seperti Irian Jaya (sekarang Papua) hanya mendapat enam persen, Kalimantan Timur hanya mendapat satu persen dan Aceh hanya mengonsumsi setengah persen dari yang diterima dari pengelolaan sumber daya lokal masing-masing. Angka-angka diatas menunjukan ketimpangan luar biasa. Sumber daya di daerah tidak berkembang, kalaupun ada, semuanya milik pusat. Semua itulah yang menghidupkan kembali atau sekurangkurangnya, membuka pemikiran ke arah sistem federal.

Pemilihan kepala daerah masih diwarnai dengan adanya tarik menarik antara kepentingan elit politik, keinginan rakyat setempat, kepentingan daerah, kepentingan nasional bahkan kepentingan negara luar (internasional). Sehingga proses demokrasi sulit sekali berkembang, kepala daerah sangat loyal terhadap pusat daripada masyarakat daerahnya sendiri hal ini dikarenakan kepala daerah dipilih oleh penguasa dari Pusat meskipun ada DPRD.

\section{b. Pemilihan Kepala Daerah pada Era Reformasi sampai dengan saat ini}

Pada Tahun 1998 terjadi gejolak politik yang dipicu juga dengan adanya krisis moneter, pergolakan politik tersebut dengan diturunkannya Presiden Soeharto, yang kemudian diteruskan oleh Presiden Habibie. Setelah jatuhnya Presiden Soeharto, langkah Presiden Habibie untuk melakukan perubahan terhadap sejumlah Undang-Undang dibidang politik, antara lain Undang-Undang Pemilihan Umum dan Undang-Undang Susunan dan Kedudukan MPR, DPR dan DPRD yang kemudian ditetapkan menjadi Undang-Undang Nomor 2, Nomor 3 dan Nomor 4 Tahun 1999 atau kerap dinamai Undang-Undang "Ji" "Sam" "Su". ${ }^{13}$

Kemudian Presiden B.J. Habibie mengadakan perubahan secara fundamental terhadap sejumlah undang-undang di bidang politik dengan melakukan reformasi politik lokal dengan mempromosikan besar-besaran desentralisasi dan otonomi daerah. Pada bulan April 1999 dengan menetapkan tanggal 1 Januari 2001 sebagai mulai dilaksanakannya desentralisasi dibawah Undang-Undang Nomor 22 Tahun 1999 tentang Pemerintahan Daerah, Undang-Undang ini memberikan konsep Otonomi Daerah seluas-luasnya bagi pemerintah maupun kepala daerah untuk mengembangkan daerahnya demi kesejahteraan masyarakat setempat. Selain itu pada Undang-Undang Nomor 22 Tahun 1999 ini telah membawa spirit baru dalam penyelenggaraan pemerintahan daerah di Indonesia karena Undang-Undang Nomor 22 Tahun 1999 ini memperkenalkan cara-cara baru 
yang progresif dalam pengelolaan Pemerintahan Daerah dan sangat berbeda dengan UndangUndang Nomor 5 Tahun 1974 pada era Orde Baru.

Pada Undang-Undang Nomor 22 Tahun 1999 dalam konteks desentralisasi politik pada otonomi daerah, demokrasi lokal juga lebih dihargai. Kedaulatan rakyat lewat wakil-wakilnya di DPRD diapresiasi sangat tinggi. Disamping itu keberadaan lembaga legislatif dan eksekutif, seperti tertuang pada Pasal 14 Ayat (1) UndangUndang Nomor 22 Tahun 1999 yaitu:" Di Daerah dibentuk DPRD sebagai Badan Legislatif Daerah dan Pemerintah Daerah sebagai Badan Eksekutif Daerah. Sementara pada Ayat (2) disebutkan Pemerintah Daerah terdiri atas Kepala Daerah beserta perangkat daerah lainnya. Sedangkan pada pasal 16 Ayat (1) menyebutkan, DPRD sebagai lembaga perwakilan rakyat di Daerah merupakan wahana untuk melaksanakan demokrasi berdasarkan Pancasila dan Ayat (2) menyebutkan bahwa bahwa DPRD sebagai Badan Legislatif Daerah berkedudukan sejajar dan menjadi mitra dari Pemerintah Daerah.

Dari uraian kedua pasal tersebut yaitu pasal 14 ayat (2)) bahwa Pemerintah Daerah hanya Kepala Daerah beserta perangkat daerah lainnya, kemudian pada pasal 16 ayat (2) menjelaskan kedudukan kedua lembaga ini sejajar dan menjadi mitra kerja. Jadi kedua pasal Undang-Undang Nomor 22 Tahun 1999 tersebut menganut paham pemisahan kekuasaan legislatif dan kekuasaan eksekutif. Perubahan Undang-Undang Nomor 22 Tahun 1999 terjadi disamping karena ada perubahan UUD 1945, juga memperhatikan beberapa ketetapan MPR dan Keputusan MPR. Selain itu Undang-Undang Nomor 22 Tahun 1999 ini pada prakteknya ternyata banyak yang pro dan kontra sehingga menimbulkan konflik karena terjadi penyimpangan khususnya pada pemilihan Kepala Daerah yaitu menunjukkan terdapat hubungan kemitraan yang tak seimbang, dikatakan begitu karena kedudukan DPRD terkesan lebih tinggi dibanding Kepala Daerah. Akibatnya, banyak kasus pemakzulan Kepala Daerah hanya karena alasan-alasan politis oleh karena itu Undang-Undang Nomor 22 Tahun 1999 ini kemudian diubah menjadi Undang-Undang Nomor 32 Tahun 2004 tentang Pemerintahan Daerah.

Pemilihan Kepala daerah secara langsung oleh rakyat pemilih melalui pemilu menurut Pasal 24 ayat (5) dan Pasal 56 Undang-Undang Nomor 32 Tahun 2004 tentang Pemerintahan Daerah jo Undang-Undang Nomor 12 Tahun 2008 tentang Perubahan Undang-Undang Nomor 32 Tahun 2004 jo Pasal 1 angka 4 Undang-Undang Nomor 15 Tahun 2011 tentang Penyelenggara Pemilu, pada model ini pasangan calon Kepala Daerah dan Wakil Kepala daerah diusulkan oleh partai politik atau gabungan partai politik yang memenuhi persyaratan, dan juga bisa dari pasangan calon perseorangan. Selanjutnya pasangan calon yang memenuhi persyaratan mengikuti kompetisi melalui pemilu untuk dipilih secara langsung oleh rakyat.

Dengan dihapuskannya kewenangan Kepala Daerah pada proses pemilihan Kepala Daerah dan Wakil Kepala Daerah dalam UndangUndang Nomor 22 Tahun 2003 tentang Susunan dan Kedudukan MPR, DPR, DPD dan DPRD menjadi alasan pemilihan Kepala Daerah secara langsung, seperti yang di tuangkan pada Undang-Undang Nomor 32 Tahun 2004 bagian penjelasan sub angka 4 yaitu: Kepala Daerah adalah Kepala Pemerintah Daerah yang dipilih secara demokratis. Pemilihan secara demokratis terhadap Kepala Daerah tersebut, dengan mengingat bahwa tugas dan wewenang DPRD 
menurut Undang-Undang Nomor 22 Tahun 2003 tentang Susunan dan Kedudukan Majelis Permusyawaratan Rakyat, Dewan Perwakilan Rakyat, Dewan Perwakilan Daerah, dan Dewan Perwakilan Rakyat Daerah, menyatakan antara lain bahwa DPRD tidak memiliki tugas dan wewenang untuk memilih Kepala Daerah dan Wakil Kepala Daerah, maka pemilihan secara demokratis dalam Undang-Undang ini dilakukan oleh rakyat secara langsung. Kepala daerah dalam melaksanakan tugasnya dibantu oleh seorang Wakil Kepala Daerah, dan perangkat daerah.

Pada perubahan Undang-Undang Nomor32 Tahun 2004 tentang Pemerintah Daerah, yakni Undang-Undang Nomor 12 Tahun 2008 tentang Pemerintahan Daerah pada Pasal 59 ayat 1b, disebutkan bahwa calon Kepala Daerah dapat juga diajukan dari calon perseorangan yang didukung oleh sejumlah orang. Sedangkan pada Undang-Undang Nomor 23 Tahun 2014 tentang Pemerintah Daerah pada Pasal 65 ayat 1 disebutkan bahwa Wakil Kepala Daerah tidak lagi dipilih secara paket bersama Kepala Daerah. Pada Pasal 65 ayat 2 Undang-Undang No. 23 Tahun 2014 tentang Pemerintah Daerah ini juga menyatakan memberi wewenang kepada Kepala Daerah untuk mengambil kebijakan khusus apabila terjadi kondisi darurat di daerah. Hal ini dikarenakan apabila Kepala Daerah dipilih secara paket dengan wakil Kapala Daerah sering terjadi ketidak cocokan dalam mengambil kebijakan sehingga wakil Kepala Daerah banyak yang mengundurkan diri.

Pada bulan Januari Tahun 2015 tentang Penetapan Peraturan Pemerintah Pengganti Undang-Undang (PERPPU) Nomor 1 Tahun 2014 tentang Pemilihan Gubernur, Bupati, dan Walikota menjadi Undang-Undang yaitu Undang Undang Nomor 1 Tahun 2015 tentang
Penetapan Peraturan Pemerintah Pengganti Undang-Undang (PERPPU) Nomor 1 Tahun 2014 tentang Pemilihan Gubernur, Bupati dan Walikota. Kemudian, sebagai konsekuensi dari penetapan PERPPU Pemilihsn Kepala Daerah secara langsung tersebut serta untuk menghilangkan ketidak pastian hukum di masyarakat, maka diterbitkanlah Perppu Nomor 2 Tahun 2014 Tentang Perubahan Undang-Undang Nomor 23 Tahun 2014 tentang Pemerintahan Daerah. PERPPU ini berisi dua hal penting, yaitu menghapus tugas dan wewenang DPRD kabupaten/kota untuk mengusulkan pengangkatan dan pemberhentian Bupati/ Wali Kota dan/atau Wakil Bupati/Wakil Wali Kota kepada Menteri Dalam Negeri melalui Gubernur sebagai wakil pemerintah pusat untuk mendapatkan pengesahan pengangkatan dan/atau pemberhentian.

\section{c. Pemilihan Kepala Daerah secara langsung menuju proses demokrasi pada Otonomi Daerah}

Setelah terjadi perdebatan yang panjang tentang Pemilihan Kepala Daerah langsung maupun Pemilihan Kepala Daerah secara tidak langsung (melalui DPRD) akhirnya pada bulan Januari Tahun 2015, Perppu No.1 Tahun 2014 mengenai perubahan atas UU No. 22 Tahun 2014 tentang Pemilihan Gubernur, Bupati, dan Walikota disahkan menjadi Undang-Undang Nomor 1 Tahun 2015, serta Perppu No.2 Tahun 2014 mengenai perubahan atas UU No.23 Tahun 2014 tentang Pemerintahan Daerah, dapat disahkan menjadi Undang-Undang meskipun masih ada perbaikan dan pada akhirnya kedua kubu yaitu KMP dan KIH, semua menyetujuinya.

Pilkada langsung sebagai sarana dan media pembelajaran demokrasi dalam berpolitik bagi rakyat dan diharapkan dapat membentuk 
kesadaran segenap rakyat Indonesia tentang pentingnya memilih pemimpin yang benar dan dapat dipercaya sesuai hati nuraninya. Pilkada langsung sebagai sarana untuk memperkuat Otonomi Daerah, keberhasilan Otonomi Daerah salah satunya juga ditentukan oleh pemimpin lokal. Semakin baik pemimpin lokal yang dihasilkan dalam pilkada langsung, maka komitmen pemimpin lokal dalam mewujudkan tujuan Otonomi Daerah, antara lain untuk meningkatkan kesejahteraan masyarakat disertai dengan selalu memperhatikan kepentingan dan aspirasi masyarakat agar dapat diwujudkan.

Pemilihan Kepala Daerah tidak terlepas dengan Otonomi Daerah, dimana Pilkada adalah hak kewenangan Pemerintah Daerah yang harus melaksanakan Pemilihan Kepada Daerah yang memiliki hak untuk mengatur dan mengurus sendiri segala urusan pemerintah daerah dan segala kepentingan masyarakat setempat karena dalam memilih Kepala Daerah tidak lagi menjadi tugas dan wewenang DPRD.

Secara filosofi, Pilkada langsung merupakan koreksi terhadap penyelenggaraan pemilihan Kepala Daerah sebelumnya. Perubahan penyelenggaraan pemerintah daerah kearah yang lebih demokratis, dimulai dengan perubahan pasal 18 ayat (4) UUD 1945 yang menjadi " Bupati dan Walikota masing-masing sebagai Kepala Pemerintahan Daerah Provinsi, kapubaten dan kota dipilih secara demokratis". Pilkada langsung dinilai sebagai jalan masuk bagi demokrasi politik di daerah, karena dapat mengeliminasi atau mengikis politik uang, dan memberikan kesempatan kepada rakyat memilih pimpinan daerah secara objektif. Pilkada langsung berarti mengembalikan hak-hak dasar masyarakat di daerah dengan memberikan kewenangan yang utuh dalam rangka memilih dan merekrut calon Kepala Daerah dengan politik lokal secara demokratis. Dalam kontek itu, negara memberikan kesempatan kepada masyarakat di daerah untuk menentukan sendiri segala bentuk kebijakan yang menyangkut harkat hidup rakyat daerah.

Keterkaitan Pasal 1 dan Pasal 18 seperti tersebut diatas, UUD menyebut pemilihan Kepala Daerah secara demokratis berarti harus dipiilih secara langsung oleh rakyat. Pemilihan Kepala Daerah secara langsung karena pada Pasal 1 ayat (2) UUD NRI 1945 setelah perubahan menjadi "kedaulatan berada di tangan rakyat dan dilaksanakan menurut Undang-Undang." jika dikaitkan dengan filsafat demokrasi antara lain:

Ide dasar dari teori kedaulatan rakyat sangat sederhana, yaitu rakyatlah yang harus menjadi sumber kekuasaan tertinggi dalam suatu negara, yang lain tidak. Rakyat berkuasa independen atas dirinya sendiri. ${ }^{14}$ Kemudian Bung Hatta mengatakan kedaulatan rakyat berarti pemerintahan rakyat. Pemerintahan yang dilakukan oleh pemimpin-pemimpin yang dipercayai oleh rakyat. ${ }^{15}$. Melihat teori demokrasi menurut filsafat demokrasi maka pemilihan Kepala Daerah juga lebih sesuai dipilih secara langsung.

Pada Undang-Undang No. 32 Tahun 2004 tentang Otonomi Daerah yang mempunyai kewenangan didalam Pemilihan Kepala Daerah yang dilandasai oleh Peraturan Pemerintah Nomor. 1 Tahun 2009 pengganti Undang-Undang

14 Hendra Nurtjahyo, Filsafat Demokrasi, (Jakarta, Bumi Aksara, 2006) hlm 32-33.

15 Kholid O santoso(Ed), Mencari demokrasi Gagasan dan Pemikiran, (Bandung, Sega Arsy, 2009) hlm 61 
No. 10 Tahun 2008 tentang Pemilihan Umum pada pasal 1 ayat 2, antara lain disebutkan:

"Undang-Undang Dasar Negara Republik Indonesia Tahun 1945 kedaulatan berada di tangan rakyat, sehingga dalam penyelenggaraan pemilihan umum, rakyat yang telah memenuhi persyaratan berdasarkan peraturan perundangundangan mempunyai hak konstitusional untuk memilih dan dipilih".

Dipilih secara demokratis bersifat luwes, sehingga mencakup pengertian pemilihan Kepala Daerah langsung oleh rakyat ataupun oleh DPRD seperti pada umumnya pernah dipraktekkan di daerah-daerah berdasarkan ketentuan perundang-undangan yang berlaku. ${ }^{16}$ Ketentuan ini memberi peluang untuk di interpretasikan bahwa Kepala Daerah harus dilakukan secara demokratis. ${ }^{17}$

Pengertian demokrasi dalam tinjauan bahasa (etimology) baik asal kata maupun asal bahasanya adalah gabungan dari dua kata dalam bahasa Yunani, yaitu "Demos" yang berarti rakyat atau penduduk suatu wilayah, dan "Cratein" atau "Cratos" yang berarti pemerintahan atau pemerintahan/ otoritas, Sehingga demokrasi sederhananya mengandung arti berarti pemerintahan rakyat atau kedaulatan/otoritas rakyat ${ }^{18}$

Moh. Mahfud MD menyatakan bahwa negara yang menganut asas demokrasi, maka kekuasaan pemerintah berada di tangan rakyat. Pada negara yang menganut asas demokrasi ini didalamnya mengandung unsur; pemerintahan dari rakyat (government of the people), pemerintahan oleh rakyat (government by the people), dan pemerintahan untuk rakyat (government for the people). ${ }^{19}$

Dalam Pancasila terkandung prinsip-prinsip demokrasi, dengan demikian, sistem politik yang cocok dengan situasi dan kondisi bangsa Indonesia yang terdiri dengan berbagai suku bangsa dan budaya yang beraneka ragam adalah sistem politik demokrasi Pancasila. Selain itu paradigma yang terdapat dalam UndangUndang Nomor 32 Tahun 2004 sebagaimana telah diubah dengan Undang-Undang Nomor 23 Tahun 2014 tentang Pemerintahan Daerah dalam pemilihan Kepala Daerah pada Otonomi Daerah adalah lebih cocok secara langsung dan serentak.

\section{d. Konflik yang terjadi dalam Pemilihan Kepala Daerah secara langsung}

Sejak diberlakukannya Undang-Undang Nomor 32 Tahun 2004, mengenai Pemilihan Kepala Daerah yang dipilih secara langsung oleh rakyat, telah banyak menimbulkan permasalahan, diantaranya waktu yang sangat panjang, sehingga sangat menguras tenaga dan pikiran, belum lagi biaya yang begitu besar,

16 Jimly Assiddique, Konsolidasi Naskah UUD 1945 Setelah Perubahan Keempat. Pusat Studi Hukum Tata Negara ( Jakarta : UI, 2002), hlm 22.

17 Sejak diberlakukan Undang-Undang Nomor 22 Tahun 2007 tentang Penyelenggaraan Pemilihan Umum, terminologi pemilihan Kepala Daerah diubah menjadi Pemilihan Umum Kepala Daerah. BAB I Pasal 1 UU Nomor 22 Tahun 2007 mengatur bahwa Pemilu Kepala Daerah dan Wakil Kepala Daerah adalah pemilu untuk memilih Kepala Daerah dan Wakil Kepala Daerah secara langsung dalam negara kesatuan Republik Indonesia berdasarkan Pancasila dan UUD 1945.

18. Ruslan Abdulgani, Beberapa Catatan tentang Pengamalan Pancasila dengan Penekanan kepada Tinjauan Sila ke-4 yaitu Demokrasi Pancasila, dalam Demokrasi Indonesia Tinjauan Politik, Sejarah, Ekonomi-Koperasi dan Kebudayaan, Yayasan Widya Patria, Yogkarta, 1995, hlm:1.

19 Moh Mahfud MD, Hukum dan Pilar-pilar Demokrasi, (Yogyakarta: Gama Media, 1999) , hlm: 8. 
baik dari segi politik (isu tentang: perpecahan internal parpol, issue tentang money politik, kecurangan dalam bentuk penggelembungan suara yang melibatkan instansi resmi, disintegrasi sosial walaupun sementara, black campaign, penghitungan suara yang salah, KPUD yang bermasalah) dan lain-lain.

Beberapa contoh kasus-kasus konflik yang terjadi pada waktu penyelenggaraan pemilihan Kepala Daerah sebelum maupun setelah Pemilihan Kepala Daerah, seperti: ${ }^{20}$

Pemilihan kepala daerah di Sumatera Barat salah satunya berlangsung di Kabupaten Padang Pariaman. Namun pemilihan kepala daerah ini melahirkan konflik antara PAN, PDIP, dan Partai Aliansi dengan KPU Padang Pariaman. KPU Padang Pariaman menolak pendaftaran pasangan bakal calon Ali Arifin dan Davip Maldian yang diusung oleh PDIP dan Partai Aliansi. Sebab menurut KPU Padang Pariaman dari pihak PDIP ditanda tangani oleh Wakil Ketua dan Wakil Sekretaris sehingga tidak memenuhi syarat pendaftaran bakal calon sebagaimana yang termuat dalam UU 32 tahun 2004 Tentang Pemerintah Daerah dan melalui PP NO.6 Tahun 2005 Tentang Pemilihan, Pengesahan, Pengangkatan, Dah Pemberhentian Kepala Daerah dan Wakil Kepala Daerah. Dan menurut KPU Padang Pariaman bahwa PDIP, Partai Aliansi, dan PAN telah mendaftarkan pasangan bakal calon Muslim Kasim dan Ali Mukhni.

Menanggapi hal tersebut PDIP tidak menerima keputusan tersebut karena menurut PDIP orang yang menandatangani berkas pencalonan tersebut sudah sesuai dengan $A D$ ART DPC PDIP dan berdasarkan rekomendasi dari DPP PDIP calon yang diusung oleh PDIP dan Koalisi Partai Politik adalah Ali Arifin dan Davip Maldian Oukan Muslim Kasim dan Ali Mukhni. Kemudian DPD PAN Padang Pariaman juga menanggapi bahwa DPD PAN Padang Pariaman tidak ikut serta pendaftaran bakal calon Bupati dan Wakil Bupati Padang Pariaman 2005-2010 karena PAN tidak mencukupi suara $15 \%$ dan tidak pernah berkoalisi dengan Partai Politik manapun.

Internasional Crisis Group (ICG) mencatat sekitar 10 persen dari 200 pemilihan umum Kepala Daerah dan Wakil Kepala Daerah yang digelar sepanjang tahun 2010 diwarnai aksi kekerasan. Konflik Pilkada di: Mojokerto, Jawa Timur, Tana Toraja di Sulawesi Selatan dan Tolitoli di Sulawesi Tengah. ICG menyebutkan bahwa kekerasan dalam Pilkada antara lain dipicu oleh lemahnya posisi penyelenggara Pemilu, seperti Komisi Pemilihan Umum Kabupaten/kota dan Panitia Pengawas Pemilu (Panwaslu) disebabkan karena: ${ }^{21}$ Adanya rasa ketidak puasan dari pasangan calon atau pendukung pasangan calon ketika gugur dalam tahap pencalonan. Kejadian ini terjadi pada Pilkada Kabupaten Mojokerto Tahun 2010.

Konflik Insiden anarkis di halaman Gedung DPRD Kabupaten Mojokerto, Jawa Timur Jumat (21/5/2010) sedikitnya mengakibatkan 22 mobil hancur dan 10 di antaranya dibakar massa dengan bom molotov saat penyampaian visi dan misi calon bupati dan calon wakil bupati setempat. Aksi rusuh ini merupakan rentetan demo yang terjadi sejak KPU Mojokerto mencoret pasangan KH Dimyati Rosyid-M. Karel dari kancah pertarungan. Aksi anarkis itu terjadi

20 http://repository.unand.ac.id/10778/ ( diakses pada tanggal 9 Februari 2015 )

21 http://gudangilmusosiologi.blogspot.com/2013/01/konflik-dalam-pilkada.html (diakses pada tanggal 23 Maret 2015) 
bersamaan penyampaian visi, misi dan program pasangan cabup-cawabup. Selain melempari bom molotov, massa juga membakar dan merusak puluhan mobil, salah satunya mobil dinas Wakil Walikota Mojokerto, H Masud Yunus, yang diundang menghadiri acara itu juga ludes dilalap api. Sumber konflik berasal dari kekesalan pendukung salah satu bakal calon bupati Mojokerto, yaitu pasangan Dimyati Rosyid-M Karel yang tidak lolos proses verifikasi oleh komisi pemilihan umum. Keputusan ini ditetapkan setelah Rumah Sakit dr Soetomo, Surabaya menegaskan surat rekomendasi hasil tes lanjutan ke dua bersifat menguatkan hasil tes kesehatan pertama. Dimana pasangan ini dianggap menderita gangguan multiorgan. Mereka mempertanyakan keabsahan pelaksanaan tahapan yang dilaksanakan KPU. Selain Mojokerto, kekerasan yang dilakukan pendukung pasangan calon akibat gugur dalam tahap pencalonan juga terjadi dalam pilkada di Kabupaten Puncak Provinsi Papua yang menewaskan sekitar 19 orang. Konflik terjadi akibat KPU setempat menolak salah satu pasangan calon yang diajukan oleh Partai Gerindra karena partai tersebut sebelumnya sudah mendaftarkan pasangan calon yang lain. Akibatnya terjadi dualisme dukungan yang diberikan oleh Partai Gerindra kepada dua pasangan calon yang berbeda.

Diakui bahwa sengketa Pilkada memang banyak diawali oleh tidak maksimalnya proses pendaftaran pemilih. Pengalaman Pilkada selama ini menunjukan bahwa ketika pemutahiran data pemilih tidak maksimal dan mengakibatkan banyaknya warga yang tidak terdaftar sebagai pemilih tetap, malah ada warga yang sudah meninggal terdaftar sebagai pemilih. Jadi tidak dapat dipersalahkan apabila terjadi berbagai protes, karena pendataan pemilih yang kurang valid tidak akurat, pada saat penetapan pemenang biasanya akan terjadi kekisruhan. Fenomena yang sering muncul adalah pihak yang kalah apalagi mengalami kekalahan dengan angka tipis selalu mengangkat isu penggelembungan suara, banyak warga yang tidak terdaftar dan persoalan pendataan pemilih lainnya sebagai sumber utama kekalahan. Massa yang merasa tidak mendapatkan hak pilihnya biasanya memprotes dan dimanfaatkan oleh pasangan yang kalah.

Pelaksanaan Pemilihan Kepala Daerah (Pilkada) kembali menorehkan cacatan buruk. Ajang yang seharusnya menjadi tempat memilih calon kepala daerah secara demokratis justru berubah menjadi kerusuhan. Itulah yang terjadi dalam pelaksanaan Pilkada di Palopo, Sulawesi Selatan. Kerugian yang ditimbulkannya pun tidak sedikit. Sejumlah kantor pemerintah nyaris ludes dibakar massa. Ini bukan pertama kalinya Pilkada menuai konflik. Tahun 2012 lalu, konflik pilkada di Puncak Ilaga, Papua, menelan 47 korban jiwa dan ratusan orang luka. ${ }^{22}$ Ada beberapa faktor pemicu konflik, Pertama, penyelenggara Pilkada kadang tidak netral. Kedua, Daftar Pemilih Tetap (DPT) yang bermasalah. Manipulasi DPT bisa digunakan untuk menggelembungkan suara, Ketiga, para elit yang bertarung di Pilkada masih menganggap politik hanya sebagai sarana untuk kekuasaan pribadi. Untuk mengikuti kontestasi pilkada, setiap calon/kandidat harus mengeluarkan dana pribadi hingga bermilyarmilyar.Kelima, konflik pilkada di berbagai daerah juga berkaitan erat dengan ketidak 
adilan ekonomi, politik, dan sosial-budaya di daerah bersangkutan. Biasanya, ketidak adilan itu akan menemukan ekspresi penyalurannya pada momentum politik seperti Pilkada.

Selain itu, Pemicu lain yang biasanya memunculkan konflik dalam Pilkada adalah tidak bersedianya DPRD menetapkan hasil Pilkada. Meskipun tidak memiliki dampak yuridis terhadap hasil Pilkada, namun penolakan DPRD tersebut memunculkan sengketa politik berkepanjangan pasca Pilkada. Seperti misalnya yang terjadi pada Pilkada Banyuwangi 2005 di mana pihak DPRD bersikukuh menolak penetapan Bupati Banyuwangi terpilih. Kasus penolakan penetapan oleh DPRD biasanya diawali oleh kekalahan pasangan calon yang didukung oleh banyak partai yang secara politik memiliki kekuatan signifikan di DPRD. Dan umumnya penolakan tersebut berujung pada tidak harmonisnya hubungan kekuatan eksekutif dan legislatif pasca Pilkada.

Dari hasil pemantauan JPPR sepanjang 2005-2007, pemicu konflik Pemilihan Kepala Daerah (PILKADA) antara lain: ${ }^{23}$

Tahun 2005 terjadi di Pilkada Maluku Utara, Pilkada Tuban. Sedangkan Tahun 2006 terjadi di Sulawesi Barat. Tahun 2007 terjadi di Pilkada Buleleng, pilkada di Maluku Utara dan Pilkada Sulawesi Selatan. Baru kali inilah pemicu konflik pilkada yang secara terang-terangan memasukan KPU pusat sebagai salah satu aktor konflik dalam pilkada. Pada tahun 2010, International Crisis Group (ICG) mempublikasikan tentang proses pilkada di tanah air, yaitu: ${ }^{24}$
Dari 244 pilkada di Indonesia yang diobservasi, kasus konflik horizontal dan kekerasan di dalam masyarakat hanya ada 20 kasus. Merujuk pada fakta itu, peluang terjadinya konflik horizontal dalam sebuah pilkada hanya sekitar 8,2\%. Masih dari hasil riset ICG, angka tersebut memang merepresentasikan terjadinya peningkatan. Pada fase pertama penyelenggaraan pilkada langsung di Indonesia sejak 2005-2008, ICG mencatat hanya terjadi 13 kasus. Namun kalaupun kita anggap saja trend ini berlanjut dan bahwa setiap 3 tahun terjadi peningkatan sebesar 53,8\% (13/2013), pada tahun 2014 ini hanya akan kita temui $47(1,538 \times 1,538 \times 20)$ kasus konflik horizontal dan kekerasan dalam seluruh proses pilkada langsung yang telah terselenggara di Indonesia. Data dari Kementerian Dalam Negeri menyebutkan, daerah di Indonesia terdiri atas 34 provinsi, 412 kabupaten, dan 93 kota. ${ }^{25}$

Melihat kasus-Kasus tersebut diatas, proses demokratisasi dapat berkembang jika demokrasi berakar pada tingkat lokal, dalam proses inilah diperlukan adanya pembelajaran politik yang efektif untuk mendorong partisipasi masyarakat dalam proses demokrasi. Apabila konflik sampai melibatkan sekumpulan masyarakat pendukung sampai menimbulkan tindakan kekerasan dalam proses pemilihan Kepala Daerah sampai menimbulkan korban yang meninggal, berarti demokrasi belum berjalan dengan sehat, yang ada hanyalah demokrasi premanisme yang tidak menggunakan rasio, karena demokrasi yang sehat dalam proses pemilihan Kepala Daerah, harus disertai proses pembelajaran

\footnotetext{
23 http://pelopor.comuf.com/Berita/Anatomi\%20Konflik-1.htm ( diakses pada tanggal 22 Maret 2015)

24 https://www.selasar.com/politik/pemilihan-kepala-daerah-langsung-rawan-konflik

25 https://www.selasar.com/politik/pemilihan-kepala-daerah-langsung-rawan-konflik ( diakses pada tanggal 2 Fabruari 2015 )
} 
untuk realistis, belajar menghargai perbedaan pendapat, dibutuhkan menerima kenyataan apabila kalah, suatu proses dimana disitu akan terbentuk pemahaman terhadap realitas sosial. Demokrasi yang tidak sehat apabila salah satu jagoannya dari calon Kepala Daerah kalah pada Pilkada berarti perang, padahal sama-sama sebangsa dan setanah air, hal itu disebabkan karena fanatisme yang berlebihan sampai berani mati demi jagoan pilihannya.

Apabila fenomena konflik pilkada yang sering ditayangkan di berbagai media elektronik, antara lain menayangkan kasus konflik kekerasan, aksi pengrusakan, pembakaran asset Negara, tawuran antar kelompok, perang opini di media sosial dan sebagainya, hal tersebut dikarenakan ketidak puasan akan penyelenggaraan pemilihan Kepala daerah yang tidak profesional, KPUD tidak netral, terjadi kecurangan, calon Kepala Daerah yang tidak siap kalah, fanatisme berlebihan karena primodialisme (primodial maksudnya ikatan-ikatan dalam masyarakat seperti kesukuan, ikatan keagamaan dan kelompok yang dibawa sejak lahir). Penyebab primodial adalah karena mereka menganggap Calon yang dijagokan dalam pemilihan Kepala Daerah dianggap memiliki keistimewaan dimata mereka, selain itu ada nya sikap ingin mempertahankan kelompoknya baik itu kesukuan karena seperti diketahui masyarakat Indonesia terdiri dari beraneka suku bangsa dan budaya sehingga rasa memiliki antar suku atau kekerabatan di daerah lebih tinggi dibanding kota besar yang cenderung individualisme. Melihat hal tersebut, sepertinya Kasus konflik di beberapa daerah, sesuai dengan teori konflik dari Clifford Geertz, yaitu bahwa konflik politik disebabkan oleh ikatan primordialisme yang mengalami percampuran antara kesetiaan politik dengan kesetiaan primordial. Sebuah ikatan primordial dapat membentuk sentimen dan loyalitas primordial yang menghasilkan solidaritas yang kuat antar kelompok. Solidaritas dalam kelompok primordial menghasilkan fanatisme yakni kesetiaan yang kuat kepada kelompok. Fanatisme ini dapat memperkuat integrasi kelompok, namun juga mempermudah terjadinya konflik dengan kelompok lain. Sikap seperti inilah yang sering dimanfaatkan di kancah perpolitikan Indonesia. Menurut Geertz, nilai-nilai primordialisme akan lebih kuat ketika berhadapan dengan nasionalisme sebab sudah merupakan sesuatu yang bersifat given, berbeda dengan nasionalisme yang jelas-jelas merupakan bentukan yang disengaja. Namun fanatisme atau kesetiaan ini bersifat tidak kekal,hanya bersifat sementara. ${ }^{26}$

Bagi negara yang baru merdeka umumnya terdapat pertentangan antara identitas baru dan identitas lama, atau biasanya dikonsepkan dengan adanya pertentangan antara primordialisme nilai-nilai yang melekat sejak awal atau sejak kelahiran seperti suku, agama, dan etnisitas dengan nasionalisme. Biasanya di masyarakat akan terjadi tarik-menarik diantara dua kepentingan dan identitas tersebut. Kemudian, masyarakat umumnya akan terjadi pembelahan sosial yang berujung pada konflik, bahkan di tingkat tertentu menyebabkan lahirnya gerakan-gerakan separatisme karena alasan-alasan diskriminasi ataupun perbedaan nilai yang dianut. Di dalam masyarakat yang

26 Clifford Geertz, "Ikatan-ikatan Primordial dan Politik Kebangsaan di Negara-negara Baru", dalam Juwono Sudarsono, (ed.)., Pembangunan Politik dan Perubahan Politik: Sebuah Bunga Rampai.( Jakarta: PT Gramedia ) 1982, hlm. 3 
multikultur hal tersebut akan lebih nampak terihat dan memungkinkan terjadi. Inilah yang umunya menjadi penyebab ketidak stabilan ekonomi dan politik pada negara-negara yang baru merdeka maupun yang sudah lama merdeka sekalipun.

Secara umum konflik ${ }^{27}$ dapat digambarkan sebagai benturan kepentingan antar dua pihak atau lebih, di mana salah satu pihak merasa diperlakukan secara tidak adil, kemudian kecewa. Dan kekecewan itu dapat diwujudkan melalui konflik dengan cara-cara yang legal dan tidak legal. Konflik juga diartikan sebagai hubungan antara dua pihak atau lebih (individu atau kelompok) yang memiliki atau merasa sasaran-sasaran yang tidak sejalan.

\section{Penutup}

Pemilihan Kepala Daerah yang dimulai dari masa orde baru melalui Undang-Undang Nomor 5 Tahun 1974 dalam prakteknya bersifat sentralistik dan cenderung otoriter Pemilihan Kepala Daerah pada masa orde baru menurut Undang-Undang seharusnya melalui DPRD akan tetapi pada prakteknya pemilihan Kepala Daerah diatur oleh pemerintah pusat, sehingga demokrasi tidak berkembang. Pemilihan kepala daerah tidak terlepas dari otonomi daerah, tahap awal pelaksanaannya, otonomi daerah di Indonesia mulai diberlakukan berdasarkan Undang-undang Nomor 22 Tahun 1999 tentang Pemerintahan Daerah. Dalam konteks desentralisasi politik, demokrasi lokal lebih dihargai dan Kedaulatan rakyat lewat wakilwakilnya di DPRD diapresiasi sangat tinggi. Pada Undang-Undang Nomor 32 Tahun 2004 calon Kepala Daerah diusulkan oleh partai politik atau gabungan partai politik dengan satu paket Kepala Daerah dan Wakil Kepala Daerah. Sedangkan Undang 23 Tahun 2014 dirubah dengan Perppu, Kepala Daerah/wakil dipilih tidak satu paket. Wakil Kepala Daerah dipilih oleh Kepala Daerah.

Model yang tepat diterapkan pada Pemilihan Kepala Daerah menuju proses demokrasi dalam Otonomi Daerah adalah Pemilihan Kepala Daerah secara langsung dan serentak. Pemilihan Kepala Daerah secara langsung adalah sebagai jalan masuk bagi demokrasi politik di daerah dan memberikan kesempatan kepada rakyat memilih pimpinan daerah secara objektif tentang pentingnya memilih pemimpin yang benar dan dapat dipercaya sesuai hati nuraninya disamping itu sebagai sarana untuk memperkuat Otonomi Daerah. Keberhasilan Otonomi daerah salah satunya juga ditentukan oleh Kepala Daerah yang asli Putra Daerah setempat. Semakin baik pemimpin lokal yang dihasilkan dalam pemilihan Kepala Daerah secara langsung, maka komitmen pemimpin lokal dalam mewujudkan tujuan Otonomi Daerah, dapat diwujudkan. Disamping itu Pilkada langsung lebih sesuai dengan demokrasi Pancasila karena, esensi Pancasila adalah kerakyatan dan terpenuhinya hak-hak rakyat. Dalam demokrasi, kedaulatan rakyat menjadi prioritas suatu sistem, di Indonesia sistem demokrasi yang digunakan adalah demokrasi pancasila mengingat bangsa Indonesia berbedabeda suku yang harus disatukan oleh demokrasi Pancasila dan Bhineka tunggal Ika.

Faktor-faktor yang menyebabkan terjadinya konflik sebelum maupun sesudah pemilihan

27 Nasikun, Sistem Sosial Indonesia, ( Jakarta: PT. Raja Grafindo Persada, 1995), hlm. 21. 
Kepala Daerah adalah, penyelenggaraan Pemilihan Kepala Daerah yang tidak netral dan tidak profesional karena awal dari pendaftaran pemilih data pemilih tidak akurat, terjadi kecurangan, banyak masyarakat yang primordialisme, fanatisme yang berlebihan, calon Kepala Daerah tidak siap kalah, kepada calon Kepala Daerah yang didukungnya terlalu berlebihan, ketika jagoannya kalah tidak puas kemudian rusuh. Selain itu beredarnya money politic dari calon Kepala Daerah agar dipilih, adanya kampanye hitam, dan sebagainya. Hal tersebut yang menjadi faktor penyebab demokrasi di beberapa daerah belum berjalan dengan sehat.

Pada undang-undang yang baru disarankan pengaturan mengenai rekrutmen Calon Kepala Daerah harus ekstra ketat, Bersih, Bebas dari Korupsi, Kolusi, Nepotisme dan bermental baik, tidak ingkar janji sehingga yang menjadi Kepala Daerah nanti tidak terjadi lagi tersangka kasus korupsi atau tersangka pidana lainnya, karena agenda penting dari demokratisasi adalah mentransformasikan janji politik Kepala Daerah menjadi program-program pembangunan yang diimplementasikan secara sistematis dan memiliki skala prioritas bukan memprioritaskan politik balas budi.

Pemilihan kepala daerah melalui pilkada langsung harus merekrut calon Kepala Daerah melalui sistem seleksi melalui KPK dan PPATK. Selain itu, segenap stakeholders pilkada mesti memiliki komitmen bersama untuk memposisikan pilkada sebagai kekuatan awal konsolidasi demokrasi di daerah. Jauh hari sebelum Pilkada diadakan, KPUD mengevaluasi penyelenggaraan Pilkada, sebelumnya terlebih dulu perlu mensosialisasikan pendidikan politik kepada masyarakat melalui media TV setempat, bisa berupa tayangan yang menarik yang bisa membangun bahwa perbedaan pendapat maupun perbedaan dukungan mengenai calon Kepala Daerah itu adalah hal biasa bukan menjadi musuh karena tidak sesuai dengan demokrasi Pancasila. Alternatifnya dengan meningkatkan konsolidasi demokrasi untuk menyempurnakan sistem demokrasi melalui pemahaman budaya hukum, budaya politik maupun budaya demokrasi Pancasila.

Selain itu Pemerintah dan DPR perlu membuat kebijakan tentang syarat bagi calon Kepala Daerah yang dapat mengedepankan asas menjunjung tinggi norma kesusilaan, kepatutan dan norma hukum, asas kepentingan umum, asas keterbukaan, asas proporsionalitas, asas profesionalitas, dan asas akuntabilitas.

Agar supaya tidak terjadi konflik pada pemilihan Kepala Daerah, intinya adalah, Calon Kepala Daerah dan Partai Politik pendukung, jangan menyuap, menyogok masyarakat, jangan sampai menyuap dan penyelenggara pilkada (KPUD dan KPUD jangan mau terima suap, agar netral, dengan bermain politik uang tersebut berarti menodai demokrasi. Selain itu data pemilih agar lebih akurat, KPUD harus bekerja sama dengan RW/RT sebelum pendaftaran Pilkada, data Kependudukan harus sering di cross check, tiga bulan sekali, jangan sampai sudah meninggal diberi kartu pemilih, yang masih hidup tidak dapat.

\section{DAFTAR PUSTAKA}

\section{Buku}

Abdulgani Ruslan, Beberapa Catatan tentang Pengamalan Pancasila dengan Penekanan kepada Tinjauan Sila ke-4 yaitu Demokrasi Pancasila, dalam Demokrasi Indonesia Tinjauan Politik, Sejarah, Ekonomi-Koperasi dan Kebudayaan. (Yogkarta: Yayasan Widya Patria, 1995) 
Abdurahman dan Soerjono, Metode Penelitian Hukum. (Jakarta: Rineke Cipta; 2003)

Assiddique Jimly, Konsolidasi Naskah UUD 1945 Setelah Perubahan Keempat. (Jakarta: Pusat Studi Hukum Tata Negara UI, 2002)

Ball.Alan R., Modern Politics and Government, (London and Basingstoke, The Macmillan Press Ltd, 1981)

Bodin Jean, Six Books Of Commonwealth Blackwell's political texts, (Michingan University: Basil. Blackwell, 1995)

Candler J.A, Local Government in Liberal Democraciest: An introductory Survey. (London and New York: Routledge, 1993)

Djohermansyah djohan, Merajut Otonomi Daerah pada Era Reformasi. (Jakarta: IKAPTK, 2014)

Geertz, Clifford. Ikatan-ikatan Primordial dan Politik Kebangsaan di Negara-negara Baru, dalam Juwono Sudarsono.(ed) Pembangunan Politik dan Perubahan Politik.: Sebuah bunga rampai (Jakarta: Gramedia, 1982)

Hadikusuma. Hilman. Metode Pembuatan Kertas Kerja atau Skripsi Ilmu Hukum. (Bandung: Mandar Maju,1995)

Hartono Sunaryati, Penelitian Hukum Di Indonesia Pada Akhir Abad Ke-20. (Bandung: Alumni, 1994)

Haris Syamsuddin dkk, Indonesia d Ambang Perpecahan? (Jakarta: Erlangga, 1999)

Huda Ni'matul, Otonomi Daerah, Filosofi, sejarah Perkembangan dan Problematika. (Yogyakarta: Pustaka Pelajar, 2013)

Mahfud MD Moh, Hukum dan Pilar-pilar Demokrasi (Yogyakarta: Gama Media, 1999)

Nurtjahyo. Hendra. Filsafat Demokrasi, (Jakarta,Bumi Aksara, 2006)

Nasikun, Sistem Sosial Indonesia, (Jakarta: PT. Raja Grafindo Persada, 1995)

Purnama. Eddy, Negara Kedaulatan Rakyat:Analisis Terhadap Sistem Pemerintahan Indonesia dan Pebandingannya dengan Negara Lain. (Bandung: Nusamedia, 2007)

SantosoKholid O (Ed), Mencari demokrasi Gagasan dan Pemikiran, (Bandung: Sega Arsy, 2009)

Soekanto Soerjono \& Sri Mamudji, Penelitian Hukum Normatif (Suatu Tinjauan Singkat). (Jakarta: Rajawali Pers, 2001)

Suharizal. Pilkada. (Jakarta: Grafindo Persada, 2011) Wignjosoebroto Soetandyo, Hukum, Paradigma Metode dan Dinamika Masalahnya, (Jakarta: Elsam, 2002)

\section{Peraturan}

Undang-Undang Dasar Negara Republik Indonesia Tahun 1945

Undang-Undang Nomor 22 Tahun 1948 tentang Pemerintahan Daerah

Undang-Undang Nomor 1 Tahun 1957 tentang Pokok-Pokok Pemerintahan Daerah

Undang-Undang Nomor 18 Tahun 1965 tentang Pokok-Pokok Pemerintahan Daerah

Undang-Undang Nomor 5 Tahun 1974 tentang Pokok-Pokok Pemerintahan di daerah

Undang-Undang Nomor 22 Tahun 1999 tentang Pemerintahan Daerah

Undang-Undang Nomor 32 Tahun 2004 tentang Pemerintahan Daerah

Undang-Undang Nomor 12 Tahun 2008 tentang Perubahan Undang-Undang Nomor 32 Tahun 2004

Undang-Undang Nomor 15 Tahun 2011 tentang Penyelenggara Pemilu Undang

Undang Nomor 15 Tahun 2011 tentang

Penyelenggara Pemilu

Undang-Undang Nomor 22 Tahun 2003 tentang Susunan dan Kedudukan MPR, DPR, DPD dan DPRD

Undang-Undang Nomor 12 Tahun 2008 tentang Pemerintahan Daerah Undang-Undang Nomor 23

Tahun 2014 tentang Pemerintah Daerah

PERPPU Nomor 1 Tahun 2014 tentang Pemilihan Gubernur, Bupati, dan Walikota

Undang Undang Nomor 1 Tahun 2015 tentang Penetapan Peraturan Pemerintah Pengganti Undang-Undang Nomor 1 Tahun 2014 tentang Pemilihan Gubernur, Bupati dan Walikota.

Perppu Nomor 2 Tahun 2014 Tentang Perubahan Undang-Undang Nomor 23 Tahun 2014 tentang Pemerintahan Daerah.

Peraturan Pemerintah Nomor 6 Tahun 2005 tentang Pemilihan, Pengesahan, dan Pengangkatan dan pemberhentian kepala Daerah

\section{Internet}

http://repository.unand.ac.id/10778/

http://gudangilmusosiologi.blogspot.com/2013/01/ konflik-dalam-pilkada.html

http://www.berdikarionline.com/editorial/ 20130402/konflik-pilkada.html

http://pelopor.comuf.com/Berita/Anatomi\%20 Konflik-1.htm 


\section{$R_{E}^{\text {dunaal }}$ HTSVINDING \\ Media Pembinaan Hukum Nasional}

https://www.selasar.com/politik/pemilihan-kepaladaerah-langsung-rawan-konflik

http://ugm.ac.id/id/berita/9346-
Volume 4, Nomor 1, April 2015

http://www.Isi.or.id/riset/202/keindonesiaankedaerahan-dan-demokrasi

http://rohmatullahh.blogspot.com/2014/03/ pengertian-demokrasi-pancasila.html 


\title{
PERUBAHAN SISTEM PEMILIHAN KEPALA DAERAH: Implikasi terhadap Calon Perseorangan dalam Perspektif Hak Asasi Manusia \\ (Changes of Local Election for Regional Leaders System: The Implications to The Individual Candidates through Human Rights Perspective)
}

\author{
Ryna Frensiska \\ Kantor Wilayah Kementerian Hukum dan HAM Kalimantan Selatan \\ Jl. Brigjen Hasan Basri Nomor 30 Banjarmasin \\ Email : rynafrensiska@yahoo.com
}

Naskah diterima: 4 Februari 2015; revisi: 24 April 2015; disetujui: 30 April 2015

\begin{abstract}
Abstrak
Pemilihan Kepala Daerah (Pilkada) di Indonesia mengalami perubahan yang cukup beragam, mulai dari pilkada secara langsung, pilkada melalui mekanisme perwakilan, yaitu dipilih oleh DPRD, hingga kembali pada pilkada secara langsung. Perubahan tersebut menimbulkan pertanyaan tentang bagaimanakah perubahan pilkada di Indonesia, khususnya bagi calon perseorangan serta implikasi perubahan pilkada bagi calon perseorangan dalam pilkada dilihat dari perspektif HAM. Dengan menggunakan pendekatan perundang-undangan dan pendekatan analitis, dapat disimpulkan bahwa ketentuan mengenai persyaratan jumlah dukungan minimal bagi calon perseorangan tidak pernah berubah, padahal jumlah dukungan minimal tersebut cukup besar. Perbedaan acuan persentase jumlah dukungan antara calon perseorangan dan calon dari partai politik memberikan kesenjangan yang lebih membebani calon perseorangan. Salah satu landasan filosofis keberadaan calon perseorangan dalam pilkada adalah untuk memenuhi hak asasi manusia, khususnya hak warga negara untuk ikut serta dalam pemerintahan. Kesenjangan yang ada tersebut menunjukkan pembentuk undang-undang belum secara total memenuhi hak warga negaranya dengan menyediakan kesempatan yang sama untuk ikut serta dalam pemerintahan. Oleh karena itu, pembentuk undang-undang harus mengkaji ulang ketentuan mengenai jumlah dukungan minimal calon perseorangan, khususnya acuan persentase jumlah dukungan minimal calon kepala daerah.
\end{abstract}

Kata kunci: Sistem Pemilihan Kepala Daerah, Calon Perseorangan, Hak Asasi Manusia

\begin{abstract}
Local elections for regional leaders (Pilkada) in Indonesia has experiences quite diverse changes from direct Pilkada, Pilkada through representative mechanism i.e. chosen by The Regional Representatives Council, and back to utilising direct Pilkada. This changes have raised question on how Pilkada's changes and implications in general, and especially to individual candidates if it is seen through human rights perspective. Using regulatory and analytical approach, it can be concluded that the provisions concerning the minimum requirements of the amount of support for individual candidate has never changed. Reference percentage difference between the amount of support for individual candidate and candidate from political party provide more gaps burdening the individual candidate. One of philosophical foundation of the existence of individual candidate in the election is to fulfill human rights, especially the rights of citizens to participate in government. Existing gap indicates the legislators have not completely fulfill the rights of its citizens by providing equal opportunities to participate in government. Therefore, legislators should review this provision, in particular the reference percentage of the minimum amount of support for regional leaders candidates.
\end{abstract}

Keywords: system of local election for regional leaders, individual candidate, human rights 


\section{A. Pendahuluan}

Berakhirnya Orde Baru pada tahun 1998, menjadi pintu masuk bagi sistem demokrasi di Indonesia. Amandemen Undang-Undang Dasar 1945 (UUD 1945) menegaskan keberlakuan demokrasi di Indonesia. Pada Orde Baru, UUD 1945 merupakan sesuatu yang sakral dan tidak dapat diusik keberadaannya walaupun sebenarnya Soekarno dengan tegas menyatakan sifat kesementaraan UUD $1945 .{ }^{1}$

Amandemen UUD 1945 dilakukan sebanyak 4 (empat) kali sejak tahun 1999 hingga 2002, dengan beberapa perubahan yang meliputi:

1. Pergeseran prinsip dari pembagian kekuasaan menuju pemisahan kekuasaan dengan tujuan memperkuat checks and balances;

2. Mengubah hubungan antarlembaga negara dengan tujuan menunjang prinsip pemisahan kekuasaan;

3. Otonomi daerah yang seluas-luasnya;

4. Penegakan hukum dan supremasi hukum. ${ }^{2}$

Sifat sentralistik pemerintahan Orde Baru merupakan diferensial keberadaan UUD 1945 sebelum amandemen. Amandemen UUD 1945 kemudian memberikan ruang bagi otonomi daerah seluas-luasnya, sebagaimana dirumuskan dalam Pasal 18 ayat (5) UUD 1945 setelah amandemen, yaitu "Pemerintahan daerah menjalankan otonomi seluas-luasnya, kecuali urusan pemerintahan yang oleh undang-undang ditentukan sebagai urusan pemerintahan pusat."

Proses demokratisasi di Indonesia tampak pada perubahan sistem pemilihan presiden secara langsung yang diatur dalam Pasal 6A UUD 1945. Semangat perubahan ini dilatarbelakangi pandangan bahwa perangkat kelembagaan haruslah berangkat dari semangat kedaulatan rakyat, selain untuk memperkuat sistem presidensial yang dianut oleh UUD $1945 .^{3}$

Berbeda dengan sistem pemilihan presiden dan wakil presiden yang dilakukan secara langsung, UUD 1945 hanya mengatur pilkada melalui sistem pemilihan demokratis. ${ }^{4}$ Klausul sistem pemilihan demokratis menjadi tidak baku karena dapat ditafsirkan melalui pemilihan secara langsung ataupun tidak langsung, dimana penilaian kedemokratisan kedua metode pemilihan tersebut tidak mutlak.

A.M. Fatwa menyatakan hal yang paling penting dalam pilkada adalah jaminan terhadap prinsip kedaulatan rakyat, baik secara langsung atau cara lain sesuai dengan keistimewaan daerah yang diatur dalam undang-undang. ${ }^{5}$

Sepanjang sejarah sejak kemerdekaan Indonesia, sistem pilkada telah beberapa kali 
mengalami perubahan. Undang-Undang Nomor 5 Tahun 1974 tentang Pokok-Pokok Pemerintahan di Daerah mengatur pemerintahan daerah format sentralisasi dengan mekanisme pilkada melalui pengangkatan oleh Presiden atau Menteri Dalam Negeri, sebagaimana diatur dalam ketentuan Pasal 16 ayat (1), (2), dan (3) Undang-Undang Nomor 5 Tahun 1974.

Pada era reformasi, Undang-Undang Nomor 5 Tahun 1974 diganti dengan Undang-Undang Nomor 22 Tahun 1999 tentang Pemerintahan Daerah, Pilkada dilakukan melalui sistem pemilihan perwakilan yang murni dipilih oleh DPRD tanpa intervensi dari pemerintah pusat namun metode perekrutan yang digunakan bersifat tertutup karena partai politik tetap memegang kewenangan dalam menentukan calon kepala daerah dan kepala daerah terpilih tanpa melibatkan rakyat. Sistem pemilihan ini belum mencerminkan perwujudan demokrasi rakyat karena DPRD memegang kendali penuh terhadap politik pemerintah daerah dan pemimpin daerah terpilih pun tidak sesuai dengan aspirasi dan keinginan rakyat.

Pasca amandemen UUD 1945, UndangUndang Nomor 22 Tahun 1999 diganti dengan Undang-Undang Nomor 32 Tahun 2004 tentang Pemerintahan Daerah. Kepala daerah dipilih langsung oleh rakyat dan harus bertanggung jawab kepada rakyat. Semangat perubahan pilkada tersebut dipengaruhi oleh beberapa hal, yaitu:

1. Pemilihan Umum Presiden dan Wakil Presiden secara langsung pada tahun 2004 yang mempengaruhi politik Indonesia sehingga memicu pendapat bahwa

pemilihan kepala daerah pun seharusnya dapat dilakukan secara langsung.

2. Pemilihan kepala daerah secara langsung dipandang sebagai wujud demokrasi, dimana selama rezim Orde Baru rakyat tidak memiliki kesempatan memilih kepala daerah sendiri.

3. Adanya desakan untuk melakukan revisi secara terbatas mengenai pemilihan kepala daerah dalam Undang-Undang Nomor 22 Tahun 1999. ${ }^{6}$

Undang-Undang Nomor 32 Tahun 2004 mengalami beberapa perubahan, yaitu melalui Undang-Undang Nomor 3 Tahun 2005 dan Undang-Undang Nomor 12 Tahun 2008. Perubahan yang terakhir membuka ruang bagi calon kepala daerah perseorangan di luar partai politik atau gabungan partai politik sehingga menguatkan sistem pilkada secara langsung sekaligus menjadi titik balik monopoli partai politik dalam pilkada di Indonesia.

Pada September 2014,melalui pengesahan Undang-Undang Nomor 22 Tahun 2014 tentang Pemilihan Gubernur, Bupati, dan Walikota, sistem pilkada diganti menjadi pilkada oleh DPRD. Perdebatan dan protes muncul di kalangan masyarakat karena pilkada tidak langsung melalui DPRD dipandang sebagai pemberangusan terhadap hak konstitusi masyarakat daerah untuk memilih kepala daerahnya secara langsung, selain itu masyarakat tidak percaya terhadap lembaga legislatif. Susilo Bambang Yudhoyono merespon pergolakan tersebut dengan menerbitkan Peraturan Pemerintah Pengganti Undang-Undang Nomor

6 BPHN, Pengkajian Hukum Pemilihan Kepala Daerah (Jakarta: BPHN Kementerian Hukum dan HAM RI, 2011) Hlm. 7. 
1 Tahun 2014 tentang Pemilihan Gubernur, Walikota, dan Bupati yang mengembalikan sistem pilkada secara langsung.

DPR memegang peranan penting dalam menentukan sistem pilkada di Indonesia. Berdasarkan ketentuan Pasal 52 Undang-Undang Nomor 12 Tahun 2011 tentang Pembentukan Peraturan Perundang-Undangan, Peraturan Pemerintah Pengganti Undang-Undang harus diajukan kepada DPR pada persidangan yang berikutnya untuk diberikan persetujuan atau tidak diberikan persetujuan menjadi UndangUndang.

Perubahan ini berimplikasi terhadap calon perseorangan dalam pilkada. Calon kepala daerah dari partai politik atau gabungan partai politik tidak akan terkena dampak langsung secara signifikan jika pilkada dilakukan melalui sistem keterwakilan karena DPRD berasal dari partai politik namun tidak demikian bagi calon perseorangan yang tidak memiliki kekuatan atau dukungan dari partai politik.

Sistem pilkada tersebut menghambat pemenuhan salah satu hak asasi manusia (HAM), yaitu hak turut serta dalam pemerintahan. UUD 1945 mengamanatkan jaminan perlindungan HAM, dimana terdapat 10 (sepuluh) hak dasar yang harus dipenuhi, salah satunya adalah hak turut serta dalam pemerintahan. UndangUndang Nomor 39 Tahun 1999 tentang Hak Asasi Manusia mengatur bahwa setiap warga negara berhak untuk dipilih dan memilih dalam pemilihan umum.

Perubahan sistem pilkada melalui keterwakilan bukan saja membawa Indonesia mundur dan mengulang konflik akibat Pilkada oleh DPRD namun juga memaksa mengingkari hak asasi warga negara untuk turut serta dalam pemerintahan.

Berangkat dari uraian tersebut diatas penulis berusaha menjawab bagaimanakah perubahan sistem pilkada di Indonesia, khususnya bagi calon perseorangan? Dan bagaimanakah implikasi perubahan sistem pilkada bagi calon perseorangan dalam pilkada dilihat dari perspektif HAM?

\section{B. Metode Penelitian}

Penelitian ini menggunakan metode penelitian hukum yuridis normatif dengan pendekatan perundang-undangan dan pendekatan analitis. ${ }^{7}$ Pengumpulan bahan hukum menggunakan studi kepustakaan berupa penelusuran kepustakaan ${ }^{8}$. Sumber bahan hukum yang digunakan adalah bahan hukum primer, yaitu peraturan perundang-undangan; bahan hukum sekunder buku-buku teks yang ditulis oleh para ahli hukum yang berpengaruh, jurnal-jurnal hukum, dan pendapat para sarjana. ${ }^{9}$ Bahan hukum diolah melalui metode deduktif, yaitu menarik kesimpulan dari suatu 
permasalahan yang bersifat umum terhadap permasalahan konkret yang dihadapi. ${ }^{10}$

\section{Pembahasan}

\section{Perubahan Sistem Pemilihan Kepala Daerah di Indonesia}

\section{a. Pemilihan Kepala Daerah di Indonesia}

Undang-Undang Nomor 5 Tahun 1974 tentang Pokok-Pokok Pemerintahan di Daerah mengatur mengenai kepala daerah yang dipilih dan dicalonkan oleh DPRD serta diangkat oleh Presiden/Menteri Dalam Negeri. Pemerintahan sentralistik Orde menghendaki segala kekuasaan dan urusan pemerintahan menjadi milik pusat, seperti penetapan kebijakan pemerintahan dan pembangunan di Indonesia. ${ }^{11}$ Peran pemerintah daerah dipersempit melalui sistem pilkada yang dianut.

UU Nomor 5 Tahun 1974 sekilas mengakui keberadaan otonomi, kepala daerah menjalankan 2 (dua) fungsi, yaitu sebagai kepala daerah otonom yang memimpin penyelenggaraan dan bertanggung jawab sepenuhnya tentang jalannya pemerintahan daerah dan bertindak sebagai kepala wilayah yang memimpin penyelenggaraan urusan pemerintahan umum yang menjadi tugas pemerintah pusat di daerah. ${ }^{12}$ Fungsi kepala daerah tersebut kemudian dibatasi oleh ketentuan mengenai sistem pilkada. Berdasarkan Pasal 16 Undang-Undang Nomor 5 Tahun 1974, DPRD mencalonkan dan memilih beberapa calon kepala daerah Tingkat I atau tingkat II untuk selanjutnya diangkat oleh Presiden atau Menteri Dalam Negeri. DPRD berwenang untuk mengusulkan calon dan memilih beberapa calon kepala daerah namun Presiden atau Menteri Dalam Negeri yang berwenang memutuskan calon yang diangkat menjadi kepala daerah tanpa terikat dengan jumlah perolehan suara para calon di tingkatan legislatif. ${ }^{13}$ Sistem ini memberikan keleluasaan Presiden untuk mengangkat calon kepala daerah dengan visi dan misi yang sejalan dengan Presiden sehingga nantinya mendukung penuh keputusan dan kebijakan Presiden terhadap daerah yang akan berimbas pada keleluasaan Presiden dalam menjalankan kekuasaannya terhadap daerah.

Pasca reformasi, terjadi perombakan sistem pilkada. Presiden atau Menteri Dalam Negeri tidak lagi memiliki kewenangan untuk mengangkat kepala daerah. Undang-Undang Nomor 22 Tahun 1999 tentang Pemerintahan Daerah memberikan iklim yang berbeda

$10 \quad$ Ibid, hlm.393.

11 Penerapan kekuasaan otoriter terpusat dan pelaksanaan program-program pemerintah Orde Baru diperantarai oleh kepentingan para elite lokal yang mengontrol lingkaran dalam hierarki administratif dan mengatur berbagai sumber ekonomi yang sangat besar hingga di tingkat desa.Dalam konteks Banten, selama Orde Baru local strongmen di provinsi tersebut (saat itu Banten masih tergabung dalam provinsi Jawa Barat) terlibat aktif dalam menjaga kepentingan Soeharto di Banten. Lihat Leo Agustino, Dinasti Politik Pasca Otonomi Orde Baru: Pengalaman Banten, Prisma (Volume 29 Nomor 3, Juli 2010).

12 Lihat dalam Penjelasan Undang-Undang Nomor 5 Tahun 1974 tentang Pokok-Pokok Pemerintahan di Daerah.

13 Beberapa kasus menunjukkan kepala daerah yang dipilih bukan merupakan calon dengan dukungan terbanyak dari DPRD. Pada Pilkada Tahun 1985, kandidat Gubernur Riau adalah Ismail Suko dan Imam Munandar. Ismail Suko memperoleh dukungan lebih banyak dibandingkan Imam Munandar namun Presiden mengangkat Imam Munandar sebagai Gubernur Riau. Begitu juga Pilkada Kabupaten Sukabumi, dimana calon kepala daerah terpilih adalah Ragam Santika yang merupakan calon nomor 2. Lihat Joko J. Prihatmoko, Pemilihan Kepala Daerah Langsung; Filosofi, Sistem, dan Problema Penerapan di Indonesia, (Yogyakarta, Pustaka pelajar, 2005), hlm. 65 
terhadap pilkada. Kepala daerah dan wakil kepala daerah dipilih secara langsung, bebas, rahasia, jujur, dan adil oleh setiap anggota DPRD dengan ketentuan calon yang memperoleh suara terbanyak akan ditetapkan sebagai pasangan kepala daerah dan wakil kepala daerah oleh DPRD dan disahkan oleh Presiden. Selain itu, keran otonomi daerah pun dibuka seluas-luasnya, pemerintah daerah diberikan kewenangan untuk mengurus daerahnya secara mandiri tanpa campur tangan pusat, kecuali dalam beberapa hal khusus yang diatur dalam undang-undang.

Undang-Undang Nomor 22 Tahun 1999 dan UU Nomor 5 Tahun 1974 dibentuk dengan payung hukum yang sama, yaitu Pasal 18 UUD 1945 namun keduanya mengatur sistem pilkada secara berbeda. Berdasarkan ketentuan Pasal 40 ayat (1), (2), dan (3) Undang-Undang Nomor 22 Tahun 1999, pilkada dilakukan dengan cara yang lebih demokratis, yaitu Kepala Daerah dan Wakil Kepala Daerah dipilih secara langsung, bebas, rahasia, jujur, dan adil oleh setiap anggota DPRD dimana calon yang mendapatkan suara terbanyak ditetapkan sebagai Kepala Daerah dan Wakil Kepala Daerah oleh DPRD dan disahkan oleh Presiden. ${ }^{14}$
Amandemen UUD 1945 membawa perubahan signifikan terhadap sistem pemerintahan daerah, salah satunya melalui Pasal 18 ayat (4) UUD 1945 yang mengatur "Gubernur, Bupati, dan Walikota masing-masing sebagai kepala pemerintahan daerah provinsi, kabupaten dan kota dipilih secara demokratis". Frase dipilih secara demokratis pada ketentuan ini maknanya tidak terbatas dan baku karena pemilihan secara tidak langsung tidak dapat disebut tidak demokratis. Sebaliknya, pemilihan secara langsung tidak dapat dikatakan lebih demokratis. ${ }^{15}$

Undang-Undang Nomor 32 Tahun 2004 tentang Pemerintahan Daerah, dibentuk pasca amandemen UUD 1945, mengatur pilkada dilakukan secara langsung oleh rakyat dan bertanggung jawab kepada rakyat sehingga memberikan kekuatan yang seimbang bagi kepala daerah dan DPRD. Kedaulatan rakyat diakui secara eksplisit, dimana Pilkada langsung merupakan bentuk penghargaan dan penilaian terhadap hak rakyat untuk memilih dan menentukan arah kehidupan kenegaraan yang dapat menjamin kesejahteraan bersama. ${ }^{16}$ Pemerintahan yang dipilih secara langsung selain membuktikan keberadaan kedaulatan

14 Pasal 40 UU Nomor 22 Tahun 1999:

(1) Pemilihan Kepala Daerah dan Wakil Kepala Daerah dilaksanakan secara langsung, bebas, rahasia, jujur dan adil.

(2) Setiap anggota DPRD dapat memberikan suaranya kepada satu pasang calon Kepala Daerah dan calon Wakil Kepala Daerah dari pasangan calon yang telah ditetapkan oleh pimpinan DPRD, sebagaimana dimaksud dalam Pasal 37 ayat (4).

(3) Pasangan calon Kepala Daerah dan calon Wakil Kepala Daerah yang memperoleh suara terbanyak pada pemilihan, sebagaimana dimaksud pada ayat (2), ditetapkan sebagai Kepala Daerah dan Wakil Kepala Daerah oleh DPRD dan disahkan oleh Presiden.

15 Hadiz, mengutip penelitian Mietzner, menyebut mayoritas pemenang Pilkada langsung adalah dari kalangan birokrat, diikuti pengusaha dan pengurus partai politik. Sifat kedemokratisan Pilkada langsung menjadi rancu karena pemenang Pilkada langsung berasal dari birokrat Orde Baru. Lihat Vedi R.Hadiz, Localising Power in Post Authoritarian Indonesia: A Southeast Asia Perspective (California: Stanford University Press, 2010) hlm. 162

16 Zainal Arifin Hoesein, Pemilu Kepala Daerah dalam Transisi Demokrasi, Jurnal Konstitusi Volume 7 Nomor 6 Desember 2010, hlm. 9. 
rakyat juga memberikan legitimasi kuat kepada kepala daerah sehingga kepala daerah akan lebih dekat dengan rakyat. ${ }^{17}$

Pilkada langsung menjadi jawaban tuntutan desentralisasi pasca Orde Baru yang berimbas pada perluasan partisipasi dan otonomi masyarakat lokal serta demokrasi. Semakin terdesentralisasi kekuasaan maka penyelenggaraan kekuasaan akan makin demokratis. ${ }^{18}$ UndangUndang Nomor 32 Tahun 2004 membawa desentralisasi dibarengi dengan sistem pemilihan yang lebih demokratis.

Perubahan UU Nomor 32 Tahun 2004 semakin memperkuat sistem pilkada langsung. Undang-Undang Nomor 12 Tahun 2008 tentang Perubahan Kedua atas Undang-Undang Nomor 32 Tahun 2004 memberikan kesempatan bagi perseorangan di luar partai politik atau gabungan partai politik untuk mencalonkan diri. Ketentuan ini dengan sengaja meruntuhkan dominasi partai politik dalam sistem pilkada.

Dinamika politik di Indonesia, melalui Undang-Undang Nomor 22 Tahun 2014 tentang Pemilihan Gubernur, Bupati dan Walikota, mengubah sistem pilkada menjadi pilkada melalui lembaga perwakilan, yaitu dipilih oleh DPRD Provinsi dan DPRD Kabupaten/Kota dengan alasan pilkada langsung mengakibatkan Negara dan pasangan calon harus mengeluarkan biaya yang sangat besar, selain berpotensi mengakibatkan timbulnya korupsi, penurunan efektifitas penyelenggaraan pemerintahan, peningkatan eskalasi konflik serta penurunan partisipasi pemilih. ${ }^{19}$

Pendanaan kampanye pilkada langsung terbilang cukup besar. Menurut Pramono Anung, pengeluaran dana kampanye dapat dikategorikan dalam tiga tingkatan, yaitu dana minimal berkisar 140-500 juta rupiah, dana standar berkisar 600-900 juta rupiah, dan dana besar berkisar 1-6 milyar rupiah. ${ }^{20}$ Pengeluaran terbesar dari dana kampanye umumnya untuk alat peraga, konsumsi dan transportasi, media, serta kegiatan fisik.

Presiden merespon perdebatan atas perubahan sistem pilkada tersebut dengan menerbitkan Peraturan Pemerintah Pengganti Undang-Undang Nomor 1 Tahun 2014, dengan alasan pentingnya kedaulatan rakyat dalam pilkada. Penolakan masyarakat terhadap pilkada keterwakilan menunjukkan pilkada keterwakilan tidak mencerminkan demokrasi. Melalui PERPPU 1 Tahun 2014, sistem pilkada kembali dilakukan secara langsung. ${ }^{21}$

\section{b. Calon Perseorangan dalam Pemilihan Kepala Daerah}

Partisipasi politik pada masa sebelum reformasi merupakan barang langka. Puncak pemberangusan partisipasi politik adalah pada Orde Baru yang memandang politik identik dengan instabilitas sehingga peran partai politik diminimalisir, salah satunya dengan melakukan fusi partaipolitik hanya menjadi dua partai politik

17 August Mellaz dan Khoirunnisa Agustyati, Keserentakan Pemilu: Pelaksanaan Pilkada Menuju Pemilu Nasional, Jurnal Pemilu dan Demokrasi (Volume 5, Februaru 2013), hlm. 188-189.

18 Rahadi T. Wiratama, Dinamika Politik Lokal di Era Reformasi, dalam Prisma Volume 29 Nomor 3, Juli 2010, LP3ES, Jakarta.

19 Lihat Penjelasan Undang-Undang Nomor 22 Tahun 2014 tentang Pemilihan Gubernur, Bupati, dan Walikota.

20 Pramono Anung Wibowo, Mahalnya Demokrasi Memudarnya Ideologi: Potret Komunikasi Politik Legislator Konstituen (Jakarta: Penerbit Buku Kompas, 2013), hlm. 175-179.

21 Lihat Penjelasan Peraturan Pemerintah Pengganti Undang-Undang Nomor 1 Tahun 2014. 
dan satu golongan, serta upaya menerapkan politik massa mengambang sehingga partai politik tidak dapat mengembangkan strukturnya ke struktur terkecil di masyarakat. ${ }^{22}$

Pada Orde Baru, sistem pilkada cenderung bersifat penunjukkan oleh Presiden atau Menteri Dalam Negeri, kepala daerah hanya berasal dari militer, birokrat, atau Golongan Karya. Pemerintah Pusat tidak memberikan ruang bagi calon kepala daerah dari partai politik apalagi dari individu di luar jalur militer, birokrat, atau Golongan Karya.

Pasca reformasi, ruang bagi individu untuk menjadi kepala daerah tetap tidak tersedia karena UU Nomor 22 Tahun 1999 membatasi calon kepala daerah berasal dari partai politik. Partai politik yang mengalami euphoria mendominasi pilkada dengan mencalonkan kepala daerah melalui fraksi di DPRD untuk kemudian dipilih oleh DPRD secara langsung, bebas, dan rahasia, judul, dan adil.

UU Nomor 32 Tahun 2004 pun tidak memberikan ruang bagi calon perseorangan untuk ikut bersaing dalam pilkada karena masih menganut sistem pencalonan terbatas yang berpegang pada paradigma hanya partai politik yang memiliki sumber daya manusia yang mumpuni dalam memimpin pemerintahan.

UU Nomor 12 Tahun 2008 menjadi antithesis dari dominasi partai politik dalam pilkada dengan membuka pintu bagi calon perseorangan ikut serta dalam pilkada. UU Nomor 12 Tahun 2008 sebenarnya merespon Putusan Mahkamah Konstitusi Nomor 5/PUU-V/2007, tanggal 23 Juli $2007^{23}$. Lalu Ranggalawe, anggota DPRD
Kabupaten Lombok Tengah, mengajukan pengujian materiil terhadap Pasal 56 Ayat (2), Pasal 59 Ayat (1), Ayat (3), Ayat (4), Ayat (5) huruf a, Ayat (5) huruf c, Ayat (6) dan Pasal 60 ayat (2), Ayat (3), Ayat (4) dan Ayat (5) Undang-Undang Nomor 32 Tahun 2004. Lalu Ranggalawe berpandangan bahwa ketentuanketentuan tersebut bertentangan dengan UUD 1945, yaitu: Pasal 18 ayat (4), Pasal 27 ayat (1), Pasal $28 \mathrm{D}$ ayat (1), Pasal $28 \mathrm{D}$ ayat (3), dan Pasal 28 I ayat (2).

Permohonan tersebut dikabulkan oleh Mahkamah Konstitusi untuk sebagian, dimana dalam pertimbangannya turut menganalisis sistem pilkada di Provinsi Aceh berdasarkan Undang-Undang Nomor 11 Tahun 2006 tentang Pemerintahan Aceh yang lebih dahulu telah memberikan ruang bagi perseorangan ikut serta dalam pilkada. Menurut Mahkamah Konstitusi, kesempatan bagi calon perseorangan dalam pilkada di Provinsi Aceh diberikan untuk menciptakan pelaksanaan pilkada yang demokratis. Sifat keistimewaan Provinsi Aceh tidak ada sangkut pautnya dengan perbedaan peserta pilkada sehingga sepatutnya seluruh daerah lain diluar Provinsi Aceh juga memberikan kesempatan kepada calon perseorangan ikut serta dalam pilkada.

Pasal 59 ayat (1) Undang-Undang Nomor 32 Tahun 2004 sebagaimana diubah dengan UU Nomor 12 Tahun 2008 merumuskan peserta pilkada dan wakil kepala daerah berasal dari partai politik dan calon perseorangan. ${ }^{24}$

Keberadaan calon perseorangan dalam pilkada secara langsung memberikan peluang 
bagi kemunculan pimpinan yang berasal dari politik arus bawah. Masyarakat tidak sekedar menjadi penonton atau pemilih calon-calon yang diusulkan oleh partai politik namun dapat bertindak sebagai aktor politik yang secara aktif mengusung calon dan memilihnya di pilkada atau bahkan menjadi calon kepala daerah. Calon perseorangan dapat dimaknai sebagai bentuk konkrit demokrasi partisipatoris yang dibangun oleh dan dalam masyarakat, kemudian menjadi contoh bagaimana demokrasi memberikan banyak pilihan calon pemimpin bagi masyarakat sekaligus menjawab kegelisahan masyarakat terhadap kredibilitas partai politik.

Keran demokrasi yang dibuka luas memang berimplikasi pada berdirinya banyak partai politik namun kuantitas partai politik ini tidak diiringi dengan kualitas kader partai politik. Secara empiris partai politik dapat dikatakan gagal dalam menjalankan salah satu fungsinya yaitu kaderisasi yang seharusnya menjadi calon pemimpin dalam skala lokal dan nasional dalam mengisi jabatan-jabatan publik. ${ }^{25}$ Padahal jika mengacu Pasal 11 Undang-Undang Nomor 2 Tahun 2008 tentang Partai Politik sebagaimana telah diubah dengan Undang-Undang Nomor 2 Tahun 2011, fungsi partai politik yang diwujudkan secara konstitusional adalah:

a. memberikan pendidikan politik baik bagi anggotanya maupun masyarakat luas;

b. menciptakan iklim yang kondusif bagi persatuan dan kesatuan bangsa Indonesia untuk kesejahteraan masyarakat; c. menyerap, menghimpun, dan menyalurkan aspirasi politik masyarakat dalam merumuskan dan menetapkan kebijakan negara;

d. sebagai sarana partisipasi politik warga negara;

e. sebagai instrument rekrutmen politik.

Kepercayaan masyarakat mengalami degradasi akibat proses pilkada sarat dengan transaksi politik. Penilaian terhadap calon yang diusung oleh partai politik bukan berdasarkan kemampuan dan kualitas tetapi atas dasar keuntungan/janji yang ditawarkan oleh calon kepada partai politik sehingga merusak keobjektivitasan partai politik dalam mengusulkan calonnya.

Transaksi semacam ini menimbulkan politic cost, misalnya saat seseorang ingin dicalonkan sebagai kepala daerah oleh partai politik tertentu, calon tersebut harus menyetorkan dana kepada partai pengusung, selain dari janji politik yang diberikan jika berhasil menduduki kursi kepala daerah sehingga menimbulkan keterikatan dengan partai politik pengusung ketika membuat kebijakan. Selain itu, calon kepala daerah meminta dukungan dana kepada pengusaha karena biaya kampanye yang tinggi. Hubungan ini mengikat kepala daerah terpilih dengan kepentingan-kepentingan pengusaha pendukung sehingga kepala daerah tidak lagi menempatkan kepentingan rakyat sebagai prioritas. ${ }^{26}$ Uang merupakan salah satu faktor

\footnotetext{
25 Miriam Budiardjo, Dasar-dasar Ilmu Politik (Jakarta, Gramedia Pustaka Umum, 2010), hlm. 408.

26 Berdasarkan laporan dana kampanye peserta Pilkada Provinsi DKI Jakarta kepada KPU, total pengeluaran kampanye sekitar 106 milyar rupiah. Lihat Didik Supriyanto dan Lia Wulandari, Basa-Basi Dana Kampanye (Jakarta: Perludem, 2013), hlm. 167-168. Mengenai dampak politik uang juga dapat dilihat pada Didik Suhariyanto, Dampak Money Politics Hasil pemilu Kepala Daerah terhadap Konstitusi dan Kebijakan Pemerintah Daerah, Jurnal Ilmiah Progresif (Volume 7 Nomor 21, Desember, 2010), hlm 1-3..
} 
yang mempengaruhi hasil kompetisi politik. ${ }^{27}$ Banyak politisi bahkan menghalalkan segala cara untuk mengumpulkan dana kampanye, seperti korupsi. ${ }^{28}$ Pada akhirnya praktik demikian memunculkan kehidupan partai politik yang bersifat oligarkis, elitis dan personalistis. ${ }^{29}$ Ibrahim Zuhdy menyatakan politic cost berdampak pada pemerintah yang berkuasa jika donator dana kampanye memberikan dukungan sebagai investasi politik bagi kepentingan mereka. ${ }^{30}$

Undang-Undang Nomor 22 Tahun 2014 memberikan perubahan signifikan terhadap sistem pilkada namun tetap menyediakan ruang bagi calon perseorangan dalam pilkada. Persyaratan dukungan yang harus dipenuhi oleh calon kepala daerah pun tidak ada perubahan sama sekali. Namun, keberadaan calon perseorangan ini menjadi sangat kontras dengan sistem pilkada keterwakilan. Pada pilkada secara langsung, calon kepala daerah melalui calon perseorangan harus melengkapi persyaratan jumlah dukungan minimal yang dibuktikan dengan fotocopy Kartu Tanda Penduduk (KTP) pendukung agar dapat masuk dalam daftar calon kepala daerah. Pada pilkada secara langsung, masyarakat daerah bersangkutan memilih calon kepala daerah tersebut secara langsung (one man one vote). Melalui mekanisme pemilihan tersebut, masyarakat pendukung calon kepala daerah dari calon perseorangan memiliki peluang untuk memilih kembali calon dukungannya.
Keberadaan calon perseorangan menjadi timpang jika dilakukan melalui pilkada keterwakilan, yaitu dipilih oleh DPRD. Calon kepala daerah dari partai politik memiliki dukungan partai dalam bentuk fraksi di DPRD namun calon kepala daerah dari calon perseorangan tidak memiliki dukungan di DPRD karena kekuatan dukungan mereka terletak pada masyarakat langsung. DPRD memang merupakan lembaga perwakilan yang sudah menjadi tugasnya mewakili masyarakat, khususnya konstituennya, di pemerintahan namun dalam menjalankan tugas dan fungsinya kesempatan bagi DPRD untuk tidak memenuhi aspirasi masyarakat pun cukup besar, terutama dalam hal pilkada.

Pilkada melalui mekanisme keterwakilan rentan terjadi pelanggaran terhadap hak asasi masyarakat, khususnya hak untuk ikut serta dalam pemerintahan. Secara garis besar, dalam pilkada melalui sistem keterwakilan terdapat dua tahapan, yaitu mengumpulkan dukungan minimal dan pemilihan itu sendiri, dimana subjek pemilih pada kedua tahapan tersebut berbeda, baik dari sisi jumlah maupun kepentingannya. Tidak dapat dipungkiri, anggota DPRD selain mewakili konstituennya juga turut mewakili partai politiknya di pemerintahan. Jika kedua pihak tersebut memiliki aspirasi yang berbeda maka anggota DPRD harus dapat memilih pihak yang diprioritaskan. Meskipun anggota DPRD memilih memprioritaskan aspirasi konstituennya, anggota DPRD tidak 
dapat memenuhi seluruh aspirasi tersebut. Pada pilkada keterwakilan, jika setiap anggota DPRD memiliki 100.000 konstituen dengan pilihan calon kepala daerah yang beragam, yang bersangkutan tidak dapat menyalurkan aspirasi tersebut dengan memilih beragam calon kepala daerah. Berbeda jika pilkada dilakukan secara langsung (one man one vote), masyarakat dapat memilih sendiri calon kepala daerahnya tanpa terhalang oleh sistem yang berlaku.

\section{Implikasi Perubahan Sistem Pemilihan Kepala Daerah terhadap Calon Perseorangan dalam Perspektif Hak Asasi Manusia}

Penegakan HAM telah menjadi perdebatan dalam penyusunan konstitusi Indonesia, Mahfud MD menyebutkan perdebatan yang terjadi mengenai apakah ketentuan HAM perlu dirumuskan secara detail atau tidak. ${ }^{31}$ Pasca amandemen UUD 1945, penegakan perlindungan HAM diatur tegas melalui melalui penambahan pasal 28 A - 28 J UUD 1945 yang mengatur mengenai sepuluh hak dasar, yaitu hak untuk hidup, hak berkeluarga dan melanjutkan keturunan, hak mengembangkan diri, hak memperoleh keadilan, hak atas kebebasan pribadi, hak atas rasa aman, hak atas kesejahteraan, hak turut serta dalam pemerintahan, hak perempuan, dan hak anak. ${ }^{32}$ Amanat jaminan HAM dalam konstitusi merupakan konsekuensi dari syarat negara hukum, dimana HAM merupakan salah satu indikator dalam mengukur tingkat peradaban, demokrasi, dan kemajuan suatu bangsa.

UUD 1945 mengamanatkan bahwa setiap warga negara memiliki hak yang sama untuk ikut serta dalam pemerintahan ${ }^{33}$ sehingga undang-undang sebagai peraturan pelaksana konstitusi wajib memberikan ruang bagi rakyat yang tidak terlibat dalam partai politik ataupun tidak mendapatkan dukungan dari partai politik untuk ikut serta dalam pemerintahan. UndangUndang Nomor 39 Tahun 1999 mengatur mengenai hak asasi warga negara Indonesia untuk memperoleh hak yang sama dalam pemerintahan. ${ }^{34}$ Sri Soemantri menyebutkan:

"Adanya jaminan terhadap hak-hak dasar setiap warga negara mengandung arti bahwa setiap penguasa dalam negara tidak dapat dan tidak boleh bertindak sewenangwenang kepada warga negaranya. Bahkan adanya hak-hak dasar itu juga mempunyai arti adanya keseimbangan dalam negara, yaitu keseimbangan antara kekuasaan dalam negara dan hak-hak dasar warga negara." 35

31 Perdebatan mengenai perlu tidaknya Negara mengatur HAM secara eksplisit dalam konstitusi terjadi antara paham individualisme dan kolektivisme. Lihat Moh. Mahfud MD, "Statuta Roma dan Politik Hukum Hak Asasi Manusia", Makalah disampaikan dalam sambutan peluncuran Buku Prof. Dr. Muladi Statuta Roma 1998 dan Perkembangan Hukum Hak Asasi Manusia (2012).

32 Lihat Pasal 28A-28J UUD 1945 dan Bab III Pasal 9 - 66 Undang-Undang Nomor 39 Tahun 1999 tentang Hak Asasi Manusia.

33 Lihat Pasal 28D ayat (3) UUD 1945

34 Pasal 43 Undang-Undang Nomor 39 Tahun 1999 merumuskan:

(1) setiap warga negara berhak untuk dipilih dan memilih dalam pemilihan umum berdasarkan persamaan hak melalui pemungutan suara yang langsung, umum, bebas, rahasia, jujur, dan adil sesuai dengan ketentuan peraturan perundang-undangan.

(2) setiap warga negara berhak turut serta dalam pemerintahan dengan langsung atau dengan perantaraan wakil yang dipilihnya dengan bebas, menurut cara yang ditentukan dalam peraturan perundang-undangan.

(3) setiap warga negara dapat diangkat dalam setiap jabatan pemerintahan.

35 Majda El-Muhtaj, Hak Asasi Manusia dalam Konstitusi Indonesia: Dari UUD 1945 sampai dengan Amandemen UUD 1945 Tahun 2002 (Jakarta, Kencana, 2005), hlm. 93-94 
Ruang yang diberikan oleh undang-undang bagi calon perseorangan untuk terlibat dalam pilkada ternyata tidak cukup mencerminkan pemenuhan HAM, yaitu hak untuk turut serta dalam pemerintahan. Penulis mengkritisi beberapa hal yang menjadi bagian dari ketentuan persyaratan yang harus dipenuhi oleh calon perseorangan.

Tabel 1 Perbandingan Ketentuan Syarat Calon Perseorangan Pemilihan Kepala Daerah

\section{UU Nomor 12 Tahun 2008}

Pasal 59 aya (2a)

Pasangan calon perseorangan sebagaimana dimaksud pada ayat (1) huruf b dapat mendaftarkan diri sebagai pasangan calon gubernur/wakil gubernur apabila memenuhi syarat dukungan dengan ketentuan:

a. provinsi dengan jumlah pendukung sampai dengan 2.000.000 (dua juta) jiwa harus didukung sekurangkurangnya 6,5\% (enam koma lima persen);

b. provinsi dengan jumlah penduduk lebih dari 2.000.000 (dua juta) sampai dengan 6.000.000 (enam juta) jiwa harus didukung sekurangkurangnya 5\% (lima persen);

c. provinsi dengan jumlah penduduk lebih dari 6.000.000 (enam juta) sampai dengan 12.000.000 (dua belas juta) jiwa harus didukung sekurang-kurangnya $4 \%$ (empat persen);

d. provinsi dengan jumlah penduduk lebih dari 12.000.000 (dua belas juta) jiwa harus didukung sekurangkurangnya 3\% (tiga persen).

\section{UU Nomor 22 Tahun 2014}

Pasal 14 ayat (1)

Calon perseorangan dapat mendaftarkan diri sebagai calon gubernur apabila memenuhi syarat dukungan dengan ketentuan sebagai berikut:

a. provinsi dengan jumlah penduduk sampai dengan 2.000.000 (dua juta) jiwa harus didukung sekurangkurangnya 6,5\% (enam koma lima persen);

b. provinsi dengan jumlah penduduk lebih dari 2.000.000 (dua juta) jiwa sampai dengan 6.000.000 (enam juta) jiwa harus didukung sekurangkurangnya 5\% (lima persen);

c. provinsi dengan jumlah penduduk lebih dari 6.000.000 (enam juta) jiwa sampai dengan 12.000.000 (dua belas juta) jiwa harus didukung sekurang-kurangnya $4 \%$ (empat persen);

d. provinsi dengan jumlah penduduk lebih dari 12.000 .000 (dua belas juta) jiwa harus didukung sekurangkurangnya 3\% (tiga persen);

e. jumlah dukungan sebagaimana dimaksud pada huruf $a$, huruf $b$, huruf $c$, dan huruf $d$ tersebar di lebih dari 50\% (lima puluh persen) jumlah kecamatan di Provinsi dimaksud.

Pasal 14 ayat (2)

Calon perseorangan dapat mendaftarkan diri sebagai calon bupati dan calon walikota apabila memenuhi syarat dukungan dengan ketentuan sebagai berikut:

a. kabupaten/kota dengan jumlah penduduk sampai dengan 250.000 (dua ratus lima puluh ribu) jiwa harus didukung sekurangkurangnnya 6,5\% (enam koma lima persen);

\section{PERPPU Nomor 1 Tahun 2014}

\section{Pasal 41 ayat (1)}

Calon perseorangan dapat mendaftarkan diri sebagai calon gubernur jika memenuhi syarat dukungan dengan ketentuan:

a. provinsi dengan jumlah penduduk sampai dengan 2.000.000 (dua juta) jiwa harus didukung paling sedikit 6,5\% (enam koma lima persen);

b. provinsi dengan jumlah penduduk lebih dari 2.000.000 (dua juta) jiwa sampai dengan 6.000.000 (enam juta) jiwa harus didukung paling sedikit 5\% (lima persen);

c. provinsi dengan jumlah penduduk lebih dari 6.000.000 (enam juta) jiwa sampai dengan 12.000.000 (dua belas juta) jiwa harus didukung paling sedikit $4 \%$ (empat persen);

d. provinsi dengan jumlah penduduk lebih dari 12.000.000 (dua belas juta) jiwa harus didukung paling sedikit 3\% (tiga persen);

e.jumlah dukungan sebagaimana dimaksud pada huruf $a$, huruf $b$, huruf $c$, dan huruf $d$ tersebar di lebih dari 50\% (lima puluh persen) jumlah kecamatan di Provinsi dimaksud.

Pasal 41 ayat (2)

Calon perseorangan dapat mendaftarkan diri sebagai Calon Bupati dan Calon Walikota, jika memenuhi syarat dukungan dengan ketentuan:

a. kabupaten/kota dengan jumlah penduduk sampai dengan 250.000 (dua ratus lima puluh ribu) jiwa harus didukung paling sedikit 6,5\% (enam koma lima persen); 
b.kabupaten/kota dengan jumlah penduduk lebih dari 250.000 (dua ratus lima puluh ribu) sampai dengan 500.000 (lima ratus ribu) jiwa harus didukung sekurangkurangnya 5\% (lima persen);

c. kabupaten/kota dengan jumlah penduduk lebih dari 500.000 (lima ratus ribu) sampai dengan 1.000.000 (satu juta) jiwa harus didukung sekurang-kurangnya $4 \%$ (empat persen); dan

d.kabupaten/kota dengan jumlah penduduk lebih dari 1.000 .000 (satu juta) jiwa harus didukung sekurangkurangnya 3\% (tiga persen). b. kabupaten/Kota dengan jumlah penduduk lebih dari 250.000 (dua ratus lima puluh ribu) sampai dengan 500.000 (lima ratus ribu) jiwa harus didukung sekurangkurangnya $4 \%$ (empat persen);

c. kabupaten/kota dengan jumlah penduduk lebih dari 500.000 (lima ratus ribu) sampai dengan 1.000 .000 (satu juta) jiwa harus didukung sekurang-kurangnya $4 \%$ (empat persen);

d. kabupaten/kota dengan jumlah penduduk lebih dari 1.000 .000 (satu juta) jiwa harus didukung sekurang-kurangnya $\quad 3 \% \quad$ (tiga persen);

e. jumlah dukungan sebagaimana dimaksud pada huruf $a$, huruf $b$, huruf $c$, dan huruf $d$ tersebuar di lebih dari 50\% (lima puluh persen) jumlah kecamatan di Kabupaten/ Kota dimaksud. b. kabupaten/kota dengan jumlah penduduk lebih dari 250.000 (dua ratus lima puluh ribu) sampai dengan 500.000 (lima ratus ribu) jiwa harus didukung paling sedikit 5\% (lima persen);

c. kabupaten/kota dengan jumlah penduduk lebih dari 500.000 (lima ratus ribu) sampai dengan 1.000 .000 (satu juta) jiwa harus didukung paling sedikit $4 \%$ (empat persen);

d. kabupaten/kota dengan jumlah penduduk lebih dari 1.000 .000 (satu juta) jiwa harus didukung paling sedikit 3\% (tiga persen);

e. jumlah dukungan sebagaimana dimaksud pada huruf $a$, huruf $b$, huruf $c$, dan huruf $d$ tersebuar di lebih dari 50\% (lima puluh persen) jumlah kecamatan di Kabupaten/ Kota dimaksud.

Pasal 59 ayat (2c)

Jumlah dukungan sebagaimana dimaksud dalam Pasal 59 ayat (2a) tersebar di lebih dari 50\% (lima puluh persen) jumlah kabupaten/kota di provinsi dimaksud.

Pasal 59 ayat $(2 d)$

Jumlah dukungan sebagaimana dimaksud dalam Pasal 59 ayat (2b) tersebar di lebih dari 50\% (lima puluh persen) jumlah kecamatan di kabupaten/kota dimaksud.

Sumber: Undang-Undang tentang Pemilihan Kepala Daerah

Sejak perubahan UU Nomor 32 Tahun 2004 melalui UU Nomor 12 Tahun 2008, sistem pilkada telah mengalami dua kali perubahan, yaitu melalui UU Nomor 22 Tahun 2014 yang mengatur sistem pilkada secara perwakilan yang segera dianulir oleh Presiden melalui PERPPU Nomor 1 Tahun 2014 dan telah disahkan menjadi undang-undang pada tanggal 20 Januari 2014 yang mengembalikan sistem pilkada secara langsung. Seluruh peraturan tersebut tetap menyediakan ruang bagi calon perseorangan dalam pilkada. Berdasarkan tabel di atas tampak tidak ada perubahan mengenai ketentuan persyaratan jumlah dukungan minimal bagi calon perseorangan yang menunjukkan selama proses pembentukkan undang-undang maupun PERPPU baik DPR maupun Presiden tidak menyadari atau tidak mau menyadari adanya beban persyaratan jumlah dukungan calon perseorangan yang tidak memiliki kekuatan pengumpul massa sebagaimana partai politik.

Perbedaan mendasar mengenai jumlah dukungan minimal calon kepala daerah adalah dalam hal acuan jumlah persentase dukungan 
minimal calon perseorangan menggunakan jumlah penduduk dalam suatu provinsi/ kabupaten/kota, sedangkan partai politik untuk dapat mencalonkan kepala daerah harus memenuhi syarat perolehan sebesar 20\% (dua puluh persen) dari jumlah kursi DPRD atau sebesar $25 \%$ (dua puluh lima persen) dari jumlah perolehan suara sah dalam pemilihan legislatif di daerah bersangkutan. Partai politik yang mencalonkan kepala daerah, acuan dukungan minimalnya menggunakan jumlah penduduk yang memiliki hak pilih dan dikerucutkan lagi menjadi penduduk yang menggunakan hak pilihnya dan dinyatakan sebagai suara yang sah. Untuk mencapai suatu tujuan yang sama, yaitu menjadi calon kepala daerah, undang-undang justru menggunakan dua acuan perhitungan yang berbeda, yaitu jumlah penduduk, dalam hal ini penduduk yang tidak dan/atau belum memiliki hak pilih tetap dihitung, dan jumlah perolehan suara sah dalam pemilihan legislatif.

Calon perseorangan berasal dari masyarakat tanpa dukungan kendaraan politik apapun, berbeda dengan calon kepala daerah yang diusulkan oleh partai politik. Beban pengumpulan jumlah dukungan minimal calon perseorangan harus dihadapi sendiri, sedangkan partai politik bekerja meraih dukungan minimal secara sistematis melalui organisasi partai maupun oleh calon legislatif sejak pemilihan umum legislatif.

Undang-Undang telah menjawab amanat pemenuhan HAM dari UUD 1945 dengan menyediakan akses bagi calon perseorangan untuk terlibat dalam pilkada namun melalui undang-undang pula masyarakat dihambat untuk terlibat karena persyaratan yang membebani dan cenderung tidak berimbang dengan calon kepala daerah dari partai politik. Pembentuk undang-undang terkesan setengah hati dalam membuka pintu bagi calon perseorangan untuk terlibat dalam Pilkada. Pada Pilkada Kabupaten Garut Tahun 2008 memang dimenangkan oleh pasangan calon perseorangan, Aceng Fikri dan Dicky Chandra, ${ }^{36}$ namun sebenarnya perlu dikaji kembali syarat jumlah dukungan minimal yang harus dipenuhi oleh calon perseorangan terutama jika dipandang dari perspektif HAM.

Pasal 28 D ayat (3) UUD 1945 dengan jelas mengamanatkan persamaan kesempatan kepada setiap warga negara dalam pemerintahan. Prinsip persamaan ini harus dimaknai tanpa diskriminasi, dimana persyaratan untuk terlibat dalam pemerintahan harus berlaku sama terhadap semua orang. ${ }^{37}$ Hak warga negara untuk mendapatkan kesempatan yang sama dalam pemerintahan pun dirumuskan dalam International Covenant on Civil and Political Rights (on Article 24), yaitu: 
"Every citizen shal have the right and the opportunity, without any of the distinctions mentioned in article 2 and without unreasonable restrictions:

(a) To take part in the conduct of public affairs, directly or through freely chosen representatives;

(b) To vote and to be elected at genuine periodic elections which shall be by universal and equal suffrage and shall be held by secret ballot, guaranteeing the free expression of the will of the electors;

(c) $\ldots . . . "$

Kovenan tersebut telah diratifikasi oleh pemerintah melalui Undang-Undang Nomor 12 Tahun 2005 tentang Pengesahan International Covenant on Civil and Political Rights (Kovenan Internasional tentang Hak-Hak Sipil dan Politik), sehingga sebagai negara peratifikasi Indonesia memiliki kewajiban untuk melaksanakan substansi kovenan tersebut.

Ketimpangan acuan jumlah persentase antara calon kepala daerah dari partai politik dan calon perseorangan menunjukkan bahwa kesempatan untuk terlibat dalam pemerintahan belum sama karena peluang bagi partai politik mengusulkan calon kepala daerah lebih besar dibandingkan calon perseorangan. Pemerintah sebagai lakon utama dalam penegakan HAM seharusnya mampu menjembatani hal tersebut.

Pasal 71 dan 72 Undang-Undang Nomor 39 Tahun 1999 mengatur kewajiban dan tanggung jawab pemerintah untuk menghormati, melindungi, menegakkan, dan memajukan HAM, yang meliputi langkah implementasi yang efektif salah satunya dalam bidang hukum dan politik. Tanggung jawab negara terhadap penegakan HAM sejalan dengan tanggung jawab dalam penegakan supremasi hukum sehingga jaminan konstitusi atas HAM memberi makna mendasar terhadap arah pelaksanaan ketatanegaraan sebuah negara.

Presiden telah merumuskan Peraturan Presiden Nomor 23 Tahun 2011 tentang Rencana Aksi Nasional Hak Asasi Manusia Indonesia Tahun 2011-2014, dimana melalui peraturan tersebut Presiden membentuk Panitia Rencana Aksi Nasional Hak Asasi Manusia (RANHAM) guna melaksanakan RANHAM, dengan program utamanya:

1. pembentukan dan penguatan institusi pelaksana RANHAM;

2. persiapan pengesahan instrument HAM internasional;

3. harmonisasi rancangan dan evaluasi peraturan perundang-undangan;

4. pendidikan HAM;

5. penerapan norma dan standar HAM;

6. pelayanan komunikasi masyarakat; dan

7. pemantauan, evaluasi dan pelaporan.

Salah satu program utama RANHAM adalah melakukan harmonisasi rancangan dan evaluasi terhadap peraturan perundang-undangan yang belum berspektif HAM. Harmonisasi hukum memilikifungsipencegahandanpenanggulangan disharmonisasi sehingga terdapat keterpaduan dalam peraturan perundang-undangan. ${ }^{38}$ Secara teoritis peraturan perundang-undangan merupakan sistem yang tidak membenarkan adanya pertentangan antara unsur dan bagian di dalamnya. ${ }^{39}$ UUD 1945 mengamanatkan

Kusnu Goesniadhie, Harmonisasi Sistem Hukum: Mewujudkan Tata Pemerintahan yang Baik (Malang: Nasa Media, 2010), hlm 10-12.

39 Disampaikan oleh Ahli Prof. Dr. Ibramsyah, M.S, dalam keterangan persidangan Mahkamah Konstitusi. Lihat Putusan MK Nomor 5/PUU-V/2007, tanggal 23 Juli 2007 
penegakan HAM dengan tegas sehingga seluruh substansi peraturan perundang-undangan harus berspektif HAM. Penulis berpendapat bahwa Undang-Undang mengenai pilkada masih belum berspektif HAM, dalam hal memberikan kesempatan yang sama bagi warga negara untuk ikut serta dalam pemerintahan. Perbedaan dasar acuan jumlah persentase yang diatur dalam undang-undang cenderung menjegal calon perseorangan untuk dapat terlibat dalam pilkada.

Pada satu sisi, undang-undang telah memberikan ruang bagi calon perseorangan untuk terlibat dalam pilkada namun melalui undang-undang pula calon perseorangan dibebani persyaratan yang tidak seimbang dengan persyaratan bagi calon kepala daerah dari partai. Beban tersebut akan semakin bertambah apabila pemerintah mengubah mekanisme pilkada menjadi secara perwakilan melalui DPRD.Seymour Martin Lipzig, sosiolog Amerika Serikat, menyampaikan bahwa hak demokrasi tidak boleh dibatasi oleh apapun karena pembatasan tersebut merupakan suatu pengkhianatan dalam demokrasi sehingga warga negara harus diperhadapkan pada kesempatan yang sama dalam persaingan memperoleh jabatan politik dan pemerintahan. ${ }^{40}$

Mahkamah Konstitusi dalam pertimbangan hukumnya menyatakan persyaratan jumlah dukungan bagi calon perseorangan tidak boleh lebih berat ataupun lebih ringan dari syarat partai politik untuk dapat mengusulkan calon kepala daerah, hal ini untuk menjaga agar tidak terjadi ketidakadilan maupun menjaga pilkada tidak diisi oleh calon yang tidak bersungguh- sungguh sehingga dapat menciderai nilai maupun citra demokrasi. Keberadaan calon perseorangan dalam pilkada sebaiknya diikuti dengan aturan pelaksanaan yang setara antara calon perseorangan dan calon dari partai politik. Ketimpangan syarat antara keduanya akan menimbulkan ketidakadilan sehingga tujuan keberadaan calon perseorangan dalam pilkada, yaitu memberikan ruang bagi masyarakat untuk terlibat langsung dalam pilkada tidak tercapai. Amanat UUD 1945 untuk memberikan perlindungan terhadap hak asasi warga negaranya, khususnya hak untuk ikut serta dalam pemerintahan dengan kesempatan yang sama belum dilaksanakan sepenuhnya oleh pemerintah.

Apabila mengacu pada filosofi dasar kemunculan calon perseorangan dalam pilkada maka sudah sepatutnya pembentuk undang-undang kelak dapat mengkaji kembali persyaratan jumlah dukungan minimal dan acuan jumlah dukungan minimal bagi calon perseorangan maupun partai politik.

\section{Penutup}

Pasca reformasi, otonomi daerah dibuka seluas-luasnya, ditandai dengan pemberian kewenangan kepada pemerintah daerah untuk mengurus daerahnya sendiri dan pemilihan kepala daerah oleh DPRD. Amandemen UUD 1945 kemudian menjadi titik balik perubahan signifikan sistem pilkada, yaitu pilkada langsung, yang didasari keinginan untuk mewujudkan kedaulatan rakyat melalui sistem pilkada yang lebih demokratis. Undang-Undang Nomor 12 Tahun 2008 kemudian membuka kesempatan 
calon perseorangan terlibat dalam pilkada, yang dilatarbelakangi oleh Putusan Mahkamah Konstitusi Nomor 5/PUU-V/2007, tanggal 23 Juli 2007.

Sistem pilkada kemudian diubah menjadi sistem keterwakilan melalui Undang-Undang Nomor 22 Tahun 2014 dengan alasan pilkada langsung menimbulkan biaya politik yang tinggi, penurunan efektifitas penyelenggaraan pemerintahan, peningkatan eskalasi konflik serta penurunan partisipasi pemilih. Perubahan ini menyebabkan pergolakan di masyarakat karena dianggap mengebiri hak rakyat memilih kepala daerahnya sehingga Presiden akhirnya menganulir melalui PERPPU Nomor 1 Tahun $2014^{41}$.

Perubahan sistem pilkada tersebut tidak meniadakan calon perseorangan namun tidak juga memberikan implikasi terhadap ketentuan bagi calon perseorangan. Tidak adanya perubahan mengenai persyaratan bagi calon perseorangan terutama syarat persentase jumlah dukungan minimal calon kepala daerah dan dasar acuan persentase jumlah dukungan, menunjukkan pembentuk undang-undang belum secara total dan utuh memenuhi hak warga negara untuk ikut serta dalam pemerintahan dengan adanya perbedaan acuan persentase jumlah dukungan antara calon perseorangan dan calon partai politik yang cenderung membebani calon perseorangan. Pasal 28 D ayat (3) UUD 1945 dan Pasal 43 Undang-Undang Nomor 39 Tahun 1999 dengan jelas mengamanatkan setiap warga negara berhak memperoleh kesempatan yang sama dalam pemerintahan. Pemerintah dalam melakukan penegakan HAM seharusnya memenuhi kewajiban tersebut dengan menye- diakan ruang serta kesempatan yang berimbang bagi masyarakat tanpa dukungan partai politik maupun yang berasal dari partai politik untuk terlibat dalam pencalonan kepala daerah.

Presiden melalui Peraturan Presiden Nomor 23 Tahun 2011 tentang Rencana Aksi Nasional Hak Asasi Manusia Indonesia Tahun 2011-2014 telah membentuk Panitia RANHAM yang salah satu program utamanya adalah melaksanakan harmonisasi rancangan dan evaluasi peratuan perundang-undangan. Perlu dilakukan kajian ulang/evaluasi terhadap PERPPU Nomor 1 Tahun 2014 yang telah disahkan menjadi undang-undang khususnya mengenai syarat dukungan minimal calon perseorangan dengan perhitungan berdasarkan jumlah penduduk dalam suatu provinsi/kabupaten/kota. Ketentuan mengenai persyaratan calon kepala daerah hendaknya lebih mengedepankan perspektif HAM dengan memberikan ruang dan kesempatan yang sama kepada masyarakat, salah satunya dengan menghilangkan perbedaan dasar acuan persentase jumlah dukungan, yaitu dengan mengganti variabel jumlah penduduk dengan jumlah penduduk yang memiliki hak pilih.

\section{DAFTAR PUSTAKA}

\section{Buku}

Amiruddin dan Zainal Asikin, Pengantar Metode Penelitian Hukum (Jakarta: Rajawali Pers, 2010)

Badoh, Ibrahim Z. Fahmi dan Abdullah Dahlan, Korupsi Pemilu di Indonesia (Jakarta: Indonesian Corruption Watch dengan dukungan Yayasan TIFA, 2010)

Badoh, Ibrahim Zuhdhy Fahmi, Kajian PotensiPotensi Korupsi Pilkada (Jakarta: ICW, 2010)

Budiardjo, Miriam, Dasar-dasar Ilmu Politik (Jakarta: Gramedia Pustaka Umum, 2010)

41 Pada tanggal 20 Januari 2015, PERPPU Nomor 1 Tahun 2014 disahkan oleh DPR menjadi undang-undang sehingga sistem Pilkada kembali pada sistem Pilkada langsung. 
BPHN, Pengkajian Hukum Pemilihan Kepala Daerah (Jakarta: BPHN Kementerian Hukum dan HAM $\mathrm{RI}, 2011$ )

El-Muhtaj, Majda,Hak Asasi Manusia dalam Konstitusi Indonesia: Dari UUD 1945 sampai dengan Amandemen UUD 1945 Tahun 2002 (Jakarta: Kencana, 2005)

Fatwa, A.M., Potret Konstitusi Pasca Amandemen UUD 1945 (Jakarta: Penerbit Buku Kompas, 2009)

Goesniadhie, Kusnu, Harmonisasi Sistem Hukum: Mewujudkan Tata Pemerintahan yang Baik (Malang: Nasa Media, 2010)

Hadiz, Vedi R., Localising Power in Post Authoritarian Indonesia: A Southeast Asia Perspective (California: Stanford University Press, 2010)

Ibrahim, Johnny, Teori dan Metodologi Penelitian Hukum Normatif (Malang: Bayumedia, 2006)

KPU Kab. Garut, Kilas Balik Pemilu Bupati \& Wakil Bupati Garut Tahun 2008 (Garut: KPU Garut, 2012)

Prihatmoko, Joko J., Pemilihan Kepala Daerah Langsung; Filosofi, Sistem, dan Problema Penerapan di Indonesia, (Yogyakarta: Pustaka Pelajar, 2005)

Subekti, Valina Singka, Menyusun Konstitusi Transisi: Pergulatan Kepentingan dan Pemikiran Dalam Proses Perubahan UUD 1945 (Jakarta: PT RajaGrafindo, 2008)

Supriyanto, Didik dan Lia Wulandari, Bantuan Keuangan Partai Politik: Metode Penetapan Besaran, Tranparansi dan Akuntabilitas Pengelolaan (Jakarta: Perludem, 2012)

Supriyanto, Didik dan Lia Wulandari, Basa-basi Dana Kampanye (Jakarta: Perludem, 2013)

Wibowo, Pramono Anung, Mahalnya Demokrasi Memudarnya Ideologi: Potret Komunikasi Politik Legislator Konstituen (Jakarta: Penerbit Buku Kompas, 2013)

Wulandari, Lia, Politik Biaya Tinggi dalam Pemilihan Kepala Daerah (Jakarta: Perludem, 2014)

\section{Makalah/Artikel/Prosiding/Hasil Penelitian}

Agustino, Leo, "Dinasti Politik Pasca Otonomi Orde Baru: Pengalaman Banten", Prisma (Volume 29 Nomor 3, Juli 2010)

Gaffar, Janedjri M., Peran Putusan Mahkamah Konstitusi dalam Perlindungan Hak Asasi Manusia terkait Penyelenggaraan Pemilu, Jurnal Konstitusi (Volume 10 Nomor 1, Maret 2013)
Goesniadhie, Kusnu, Perspektif Moral Penegakan Hukum yang baik, Jurnal Hukum (Volume 17 Nomor 2, April 2010)

Hoesein, Zainal Arifin, Pemilu Kepala Daerah dalam Transisi Demokrasi, Jurnal Konstitusi (Volume 7 Nomor 6, Desember 2010)

MD, Moh. Mahfud, "Statuta Roma dan Politik Hukum Hak Asasi Manusia"(makalah disampaikan dalam sambutan peluncuran Buku Prof. Dr. Muladi "Statuta Roma 1998 dan Perkembangan Hukum Hak Asasi Manusia, 2012)

Mellaz, August dan Khoirunnisa Agustyati, Keserentakan Pemilu: Pelaksanaan Pilkada Menuju Pemilu Nasional, Jurnal Pemilu dan Demokrasi (Volume 5, Februari, 2013)

Suhariyanto, Didik, Dampak Money Politics Hasil Pemilu Kepala Daerah terhadap Konstitusi dan Kebijakan Pemerintah Daerah, Jurnal IImiah Progresif (Volume 7 Nomor 21, Desember, 2010)

Wiratama, Rahadi T., Dinamika Politik Lokal di Era Reformasi, Prisma (Volume 29 Nomor 3, Juli 2010)

Zoelva, Hamdan, Memberantas Electoral Corruption, Jurnal Pemilu dan Demokrasi (Volume 5, Februari 2013)

\section{Peraturan}

International Covenant on Civil and Political Rights

Undang-Undang Nomor 5 Tahun 1974 tentang Pokok-Pokok Pemerintahan di Daerah

Undang-Undang Nomor 22 Tahun 1999 tentang Pemerintahan Daerah

Undang-Undang Nomor 39 Tahun 1999 tentang Hak Asasi Manusia

Undang-Undang Nomor 32 Tahun 2004 tentang Pemerintahan Daerah

Undang-Undang Nomor 12 Tahun 2005 tentang Pengesahan International Covenant on Civil and Political Rights (Kovenan Internasional tentang Hak-Hak Sipil dan Politik)

Undang-Undang Nomor 12 Tahun 2008 tentang Perubahan Kedua atas Undang-Undang Nomor 32 Tahun 2004

Undang-Undang Nomor 22 Tahun 2014 tentang Pemilihan Gubernur, Bupati, dan Walikota

Peraturan Pemerintah Pengganti Undang-Undang Nomor 1 Tahun 2014 tentang Pemilihan Gubernur, Bupati, dan Walikota

Peraturan Presiden Nomor 23 Tahun 2011 tentang Rencana Aksi Nasional Hak Asasi Manusia Indonesia Tahun 2011-2014 


\title{
MEWUJUDKAN SISTEM PENYELESAIAN HASIL Pilkada YANG EFEKTIF DAN BERKEADILAN
}

(Manifesting Effective and Fair Resolution Systems on the Local Election Results)

\author{
Kelik Pramudya \\ MT\&P LAW FIRM
}

Jl. Songgorunggi 17A, Laweyan, Surakarta, Jawa Tengah

Email: kelik_pramudya@yahoo.co.id

Naskah diterima: 3 Februari 2015; revisi: 24 April 2015; disetujui: 30 April 2015

\begin{abstract}
Abstrak
Penyelenggaraan pemilihan kepala daerah secara langsung di daerah sering menimbulkan sengketa mengenai penetapan hasil perolehan suara. Upaya yang dilakukan oleh calon yang tidak puas atas penetapan ini ialah mengajukan pembatalan ke lembaga peradilan. Pembaharuan mengenai sistem penyelesaian hasil pemilihan dilakukan pemerintah untuk mengatasi masalah ini yaitu Peraturan Pemerintah Pengganti Undang-Undang Nomor 1 Tahun 2014. Masalah yang dibahas dalam penelitian ini antara lain: bagaimana mekanisme penyelesaian sengketa sebelum dikeluarkan peraturan tersebut, apa pembaruan yang terdapat dalam peraturan tersebut dan bagaimana mewujudkan penyelesaian perselisihan hasil pemilihan yang efektif dan berkeadilan. Penelitian ini merupakan penelitian hukum normatif yang bersifat deskriptif dengan menggunakan pendekatan perundang-undangn dan analitis. Berdasarkan hasil penelitian dapat disimpulkan bahwa pembaharuan mendasar terletak pada lembaga yang berwenang menangani yaitu dari Mahkamah Konstitusi beralih ke Pengadilan Tinggi yang ditunjuk oleh Mahkamah Agung. Penulis merekomendasikan bahwa pembaharuan tersebut harus didukung oleh peraturan teknis untuk menjamin kefektifan dan memenuhi rasa keadilan.
\end{abstract}

Kata kunci: Pilkada, Sengketa, Pemerintah Daerah

\section{Abstract}

The implementation of the direct local elections for regional leaders in the regional level often give rise to disputes on the determination of voting results. The efforts made by a candidate who is not satisfied with the determination is to submit the cancellation to the judiciary. Renewal on the system of electoral dispute settlement which has been undertaken by the government to deal with the problem is Government Regulation in Lieu of Law Number 1 of 2014. Problems addressed in this research, among others: how the electoral dispute settlement mechanisms works before the regulation was issued, what renewal that is found in the regulation ands how to create a fair and effective electoral dispute settlement. This research is a descriptive-normative legal research by using regulatory and analytical approachs. It can be concluded from the research that the fundamental renewal takes place in the institution authorized to handle the dispute settlement that is from the Constitutional Court to the high courts appointed by the Supreme Court. The author recommends that the renewal must be supported by technical regulations to ensure effectiveness and meet the sense of justice.

Keywords: direct local elections for regional leaders, dispute, local government 


\section{A. Pendahuluan}

Penyelenggaraan pemerintahan daerah di Indonesia dilaksanakan menurut prinsip demokrasi sebagaimana telah ditetapkan dalam Pasal 18 ayat (4) UUD NRI 1945. Dalam pasal tersebut diatur bahwa kepala daerah dipilih secara demokratis. Pengaturan mekanisme jabatan kepala daerah dalam konstitusi pasca amandemen menunjukkan bahwa pengisian kepala daerah dalam lingkup pemerintahan daerah menjadi bagian penting dalam demokratisasi di Indonesia. Ketentuan tersebut kemudian dipertegas dalam Undang-Undang Nomor 32 Tahun 2004 tentang Pemerintahan Daerah, di mana pemilihan kepala daerah dan wakil kepala daerah yang dipilih secara langsung oleh rakyat yang diajukan oleh partai politik atau gabungan partai politik. Sebelumnya gubernur, bupati dan walikota dipilih oleh sekelompok orang tertentu yakni para anggota Dewan Perwakilan Daerah (DPRD) sesuai dengan tingkatannya masing-masing, maka dengan diberlakukannya Undang-Undang tersebut mereka harus dipilih secara langsung oleh seluruh rakyat yang memiliki hak pilih di masingmasing daerah. Pemilihan kepala daerah telah menjadi bagian yang tidak terpisahkan dalam pembangunan demokrasi di Indonesia. Sistem pemilihan secara langsung ini telah membuka keterlibatan seluas-luasnya bagi segenap rakyat dalam proses pemilihan pemimpin pemerintahan daerah mereka. Selain merupakan implikasi dari posisi pemerintahan daerah yang menjadi lebih otonom dari pemerintah pusat, keinginan untuk memberikan pendidikan politik dalam proses berdemokrasi tampaknya juga melatarbelakangi lahirnya Undang-Undang Pemerintahan Daerah. ${ }^{1}$ Menurut Mahfud MD ada dua alasan mengapa pemilihan langsung dianggap perlu. Pertama, pemilihan langsung lebih membuka peluang tampilnya calon pemimpin yang sesuai dengan kehendak mayoritas rakyat. Kedua, untuk menjaga stabilitas pemerintahan agar tidak mudah dijatuhkan di tengah jalan oleh parlemen. ${ }^{2}$ Pemilihan kepala daerah secara langsung jelas memberikan kesempatan kepada rakyat untuk aktif berpartisipasi dalam membangun daerahnya melalui pemimpin yang mereka pilih. Sistem pilkada seperti ini didasarkan pada prinsip demokrasi yang dianut oleh bangsa Indonesia. Selain itu, prinsip demokrasi atau kedaulatan rakyat dapat menjamin peran serta masyarakat dalam proses pengambilan keputusan, sehingga setiap peraturan perundang-undangan yang diterapkan dan ditegakkan benar-benar mencerminkan perasaan keadilan masyarakat. ${ }^{3}$ Dalam konsep otonomi daerah kepala daerah memiliki peran penting yang menentukan dalam pemerintahan daerah. Kewenangan yang dimiliki oleh kepala daerah akan menentukan pembangunan dan kesejahteraan daerahnya, atau dengan kata lain keberhasilan pembangunan dan peningkatan kesejahteraan rakyat di daerah ditentukan oleh kepala daerah. Oleh karena itu diperlukan kepemimpinan kepala daerah yang berkualitas. Melalui pemilihan langsung ini akan memperbesar harapan untuk mendapatkan figur pemimpin 
aspiratif, kompeten dan mempunyai legitimasi tinggi di hadapan rakyat. ${ }^{4}$

Namun disisi lain, pemilihan Kepala Daerah (Gubernur, Bupati/ Walikota) yang berlangsung di berbagai daerah sekarang ini juga memiliki banyak catatan tentang kecurangan dan diabaikannya kesejahteraan masyarakat pasca Pilkada langsung. Pelaksanaan demokrasi di daerah ini tidak jarang hanya menjadi ajang perebutan kekuasaan dan pertaruhan kepentingan sejumlah kalangan. ${ }^{5}$ Praktek money politic, black campaign, membeli suara, dan kecurangan dalam penghitungan suara menjadi awal wajah Pilkada langsung yang tidak dapat dielakkan ${ }^{6}$. Banyaknya pelanggaran yang terjadi tersebut berujung pada sengketa hasil pilkada di mana calon yang kalah akan mengajukan gugatan di lembaga peradilan.Berbagai permasalahan yang seringkali terjadi dalam pelaksanaan Pilkada di Indonesia menunjukkan bahwa masih belum adanya perangkat penegakan hukum yang efektif dan memenuhi rasa keadilan. Oleh karena itu dengan pertimbangan mengurangi sengketa yang terjadi dan menghemat anggaran Dewan Perwakilan Rakyat (DPR) menyusun Undang-Undang baru tentang Pemilihan Kepala Daerah yaitu Undang-Undang Nomor 22 Tahun 2014 di mana diatur pemilihan kepala daerah dilakukan melalui DPRD. Menurut Arif Maulana, pengembalian sistem pemilihan kepala daerah melalui DPRD memang tidak melanggar konstitusi, hanya saja hal ini merupakan suatu bentuk kemunduran proses demokrasi dan bukan jaminan akan memperbaiki keadaan. Pemilihan secara langsung sebaiknya tetap dipertahankan dengan catatan harus dilakukan perbaikan terhadap berbagai kelemahan yang ada dengan mengupayakan efektifitas penyelenggaraan Pilkada dan tetap menjaga tetap tegaknya prinsip-prinsip demokrasi dengan tujuan demokratisasi mampu memberikan dampak kesejahteraân kepada masyarakat. ${ }^{7}$

Undang-Undang Nomor 22 Tahun 2014 tersebut mendapat penolakan keras termasuk dari Presiden Susilo Bambang Yudhoyono yang kemudian mengeluarkan Peraturan Pemerintah Pengganti Undang-Undang (Perppu) Nomor 1 Tahun 2014. Perppu Nomor 1 Tahun 2014 tersebut disahkan DPR melalui sidang paripurna di mana semua fraksi menyetujui. Perppu ini kemudian disahkan menjadi Undang-Undang Nomor 1 Tahun 2015. Dalam Perppu tersebut masih dikehendaki bahwa Pemilihan Kepala Daerah harus dilakukan secara langsung oleh rakyat. Beberapa materi penting dalam Perppu tersebut salah satunya tentang pembaharuan penyelesaian sengketa hasil Pilkada. Namun, mekanisme tersebut kemudian diubah dengan Undang-Undang Nomor 8 Tahun 2015. Membahas mengenai penyelesaian sengketa sangatlah menarik karena dari sini dapat diuji apakah keadilan dan kepastian hukum dapat diwujudkan.

\footnotetext{
Suharizal, Pilkada, Regulasi, Dinamika dan Konsep Mendatang (Jakarta: Raja Grafindo Persada, 2011), hlm. 39.

5 Janpatar Simamora, "Eksistensi Pilkada Dalam Rangka Mewujudkan Pemerintahan Daerah yang Demokratis," Mimbar Hukum Volume 23, Nomor 1, (2011): 231.

6 Dyah Mutiarin, Nur Hayati, dan Delina Asriyani:" Analisis Dampak Positif dan Negatif dalam Pilkada Langsung bagi Kualitas Pelayanan Publik di Daerah" (Paper disajikan dalam Forum Ilmiah Nasional Program Pascasarjana, UMY, 24 Desember 2011), hlm. 1.

7 Arif Maulana. Tinjauan Konstitusional Pengisian Jabatan Kepala Daerah dan Wakil Kepala Daerah Melalui Pemilihan Umum (Tesis). (Jakarta: Universitas Indonesia, 2012), hlm. 147
} 
Berdasarkan latar belakang di atas maka permasalahan yang dibahas dalam penelitian ini sebagai berikut:

1. Bagaimana penyelesaian perselisihan hasil Pilkada sebelum dikeluarkannya Perppu Nomor 1 Tahun 2014 ?

2. Apa pembaharuan yang muncul dalam penyelesaian perselisihan hasil Pilkada setelah dikeluarkannya Perppu Nomor 1 Tahun 2014?

3. Bagaimana penyelesaian perselisihan hasil Pilkada yang efektif dan berkeadilan?

\section{B. Metode Penelitian}

Penelitian ini termasuk dalam penelitian hukum normatif yaitu penelitian hukum yang dilakukan dengan cara meneliti bahan pustaka yang terdiri dari bahan hukum primer, bahan hukum sekunder, dan bahan hukum tersier. $^{8}$ Penelitian ini bersifat deskriptif dengan menggunakan pendekatan perundangundangan (statute approach) dan pendekatan analitis. Jenis data yang digunakan dalam penelitian hukum ini adalah data sekunder. Data ini tidak diperoleh langsung di lapangan, tetapi diperoleh dari bahan pustaka. Untuk memperoleh bahan-bahan hukum yang diperlukan, dilakukan dengan cara penelusuran, pengumpulan dan pengkajian bahan-bahan kepustakaan, peraturan perundang-undangan, hasil penelitian, karya-karya ilmiah serta dokumen-dokumen tertulis lainnya.

\section{Pembahasan}

\section{Penyelesaian Perselisihan Hasil Pilkada Sebelum Perppu Nomor 1 Tahun 2014}

Pemilihan kepala daerah secara langsung merupakan salah satu pembaharuan dalam sistem demokrasi di Indonesia dalam rangka melaksanakan kedaulatan rakyat secara penuh. Pemilihan kepala daerah ini didasari Pasal 18 ayat (4) UUD NRI 1945 pasca amandemen yang berbunyi: "Gubernur, Walikota masing-masing sebagai kepala pemerintahan daerah provinsi, kabupaten, dan kota dipilih secara demokratis". Sejak berlakunya Undang-Undang Nomor 32 Tahun 2004 Tentang Pemerintahan Daerah maka telah tercipta suasana baru dalam proses pemilihan kepala daerah baik di tingkat propinsi maupun di tingkat kabupaten dan kota. Pilkada merupakan suatu aktifitas dari proses demokrasi yang tidak terlepas dari penyelenggaraan pemilu karena Pilkada mempunyai output yakni pejabat politik (elected official) bukan memilih pejabat administratif (appointed official) ${ }^{9}$. Pilkada langsung diharapkan dapat mendorong tumbuhnya kepemimpinan eksekutif daerah yang kuat dan berkualitas. Dengan demikian, kepala daerah akan lebih akuntabel pada rakyat dan bukan pada golongan tertentu yang pada akhirnya pengambilan kebijakan publik selalu berorientasi pada kepentingan rakyat, dan jauh dari Kolusi, Korupsi, dan Nepotisme $(K K N)^{10}$. Namun, pelaksanaan Pilkada menimbulkan masalah baru dengan adanya pelanggaran yang merusak sistem dan tatanan demokrasi. Beberapa pelanggaran yang terjadi di Pilkada

Soerjono Soekanto dan Sri Mahmuji. Penelitian Hukum Normatif(Jakarta: Rajawali Pers, 2007), hlm. 14.

Ari Pradhanawati, Pilkada Langsung Tradisi Baru Demokrasi Lokal (Surakarta: Pustaka Rumpun Ilalang, 2005), hlm. 144.

10 Lomba Sultan, "Sistem Pemilihan Umum Kepala Daerah," Al-Fikr Volume 15 Nomor 2 (2011): 160. 
misalnya: pelanggaran administratif, money politic $^{11}$, intimidasi, dan penganiayaan. Oleh sebab itu, pengaturan Pilkada memang seharusnya ditinjau ulang mengingat sering terjadi pelanggaran pada setiap penyelenggaraannya, salah satunya mengenai penyelesaian perselisihan hasil Pilkada.

Sengketa hasil Pilkada sejak tahun 2008 diselesaikan melalui persidangan di Mahkamah Konstitusi sebagaimana diatur dalam UndangUndang Nomor 12 Tahun 2008 setelah sebelumnya menjadi kewenangan Mahkamah Agung. ${ }^{12}$ Menurut Undang-Undang Nomor 12 Tahun 2008 setiap perselisihan hasil Pilkada di Indonesia menjadi kewenangan Mahkamah Konstitusi. Hal ini sebagaimana pengaturan Pasal 236C yang menegaskan bahwa:"Penanganan sengketa hasil penghitungan suara pemilihan kepala daerah dan wakil kepala daerah oleh Mahkamah Agung dialihkan kepada Mahkamah Konstitusi paling lama 18 (delapan belas) bulan sejak Undang-Undang ini diundangkan."Kewenangan Mahkamah Konstitusi sendiri diatur dalam Pasal 24C UUD NRI 1945 serta Undang-Undang Nomor 24 Tahun 2003 tentang Mahkamah Konstitusi sebagaimana telah diubah dengan Undang-Undang Nomor 8 Tahun 2011 yang salah satunya ialah memutus perselisihan tentang hasil pemilihan umum. Namun, bila diperhatikan dalam Undang-Undang Nomor 12 Tahun 2008 tidak menyebut latar belakang mengapa kewenangan tersebut kemudian beralih ke Mahkamah Konstitusi.

Mahkamah Konstitusi dalam menangani sengketa Pilkada tidak hanya membedah permohonan dengan melihat perolehan hasil suara, melainkan juga meneliti secara mendalam adanya pelanggaran yang bersifat terstruktur, sistematis, dan masif yang mempengaruhi hasil perolehan suara tersebut. ${ }^{13}$ Pada dasarnya pelanggaran Pilkada yang bersifat sistematis, terstruktur, dan masif ini adalah pelanggaran Pemilu biasa, tetapi karena memiliki unsur sistematis, terstruktur dan masif, sehingga pelanggaran ini dapat membatalkan hasil Pilkada. Istilah sistematis, terstruktur, dan masif adalah sebagai berikut: ${ }^{14}$

a. Pelanggaran itu bersifat sistematis, artinya pelanggaran ini benar-benar direncanakan secara matang (by design);

b. Pelanggaran itu bersifat terstruktur, artinya pelanggaran ini dilakukan oleh aparat struktural, baik aparat pemerintah maupun aparat penyelenggara Pilkada secara kolektif bukan aksi individual;

11 Menurut Yusril Ihza Mahendra definisi money politic sangat jelas, yakni mempengaruhi massa pemilu dengan imbalan materi. Apabila kasus money politic bisa di buktikan, pelakunya dapat dijerat dengan pasal tindak pidana biasa, yakni penyuapan. Lihat Indra Ismawan, Money Politics Pengaruh Uang Dalam Pemilu (Yogyakarta: Media Presindo, 1999), hlm. 4.

12 Mustafa Lutfi, Hukum Sengketa Pilkada di Indonesia, Gagasan Perluasan Konstitusional Mahkamah Konstitusi (Yogyakarta: UII Press, 2010), hlm. 151.

13 Hal ini sejalan dengan ketentuan yang mengharuskan Mahkamah Konstitusi memutus sengketa berdasarkan kebenaran materiil sebagaimana ditegaskan dalam Pasal 45 ayat (1) UU MK yang menyatakan, "Mahkamah Konstitusi memutus perkara berdasarkan Undang-Undang Dasar Negara Republik Indonesia Tahun 1945 sesuai dengan alat bukti dan keyakinan hakim."

14 M. Mahrus Ali et. al. Tafsir Konstitusional Pelanggaran Pilkada yang Bersifat Sistematis, Terstruktur, dan Masif (Jakarta: Pusat Penelitian dan Pengkajian Kepaniteraan dan Sekretariat Jenderal Mahkamah Konstitusi Republik Indonesia, 2011), hlm. 24-25. 
c. Pelanggaran itu bersifat masif, artinya dampak pelanggaran ini sangat luas dan bukan sporadis.

Dalam berbagai putusan Mahkamah Konstitusi telah memberikan makna hukum dan keadilan dalam penanganan permohonan baik Pengujian Undang-Undang maupun sengketa Pemilu atau Pilkada.

Peralihan kewenangan Mahkamah Agung ke Mahkamah Konstitusi ini menimbulkan banyaknya perkara sengketa hasil pilkada yang masuk ke Mahkamah Konstitusi karena hampir setiap pelaksanaan Pilkada selalu menimbulkan masalah mengenai penetapan hasil. Akibatnya penyelesaian sengketa hasil Pilkada dirasakan tidak berjalan efektif. Banyaknya perkara Pilkada yang masuk ke Mahkamah Konstitusi menimbulkan tekanan beban kerja yang cukup besar terhadap sembilan hakim konstitusi. Tekanan ini terjadi akibat banyaknya perkara yang masuk dan singkatnya waktu penyelesaian yang menurut Undang-undang hanya 14 hari kerja. Bertambahnya kewenangan mengadili sengketa Pilkada yang begitu banyak cenderung menjadikan Mahkamah Konstitusi sebagai Mahkamah Sengketa Pemilu (Election Court) karena jumlah perkara sengketa pemilu yang ditangani lebih banyak volumenya dibandingkan pengujian Undang-undang (Judicial Review) yang merupakan kewenangan utama. Namun demikian, tidak dapat dipungkiri bahwa dalam kenyataannya Mahkamah Konstitusi berperan penting dalam penyelesaian sengketa hasil Pilkada. Mahkamah Konstitusi mampu memfasilitasi konflik politik yang merupakan hasil Pilkada dengan membawanya dari konflik yang terjadi, yang bisa memicu konflik horizontal antar pendukung ke gedung Mahkamah Konstitusi. Di tingkat tertentu Mahkamah Konstitusi telah memiliki prestasi dalam mendorong pelaksanaan Pilkada yang demokratis. Akan tetapi, dalam titik tertentu, Mahkamah Konstitusi juga memiliki masalah yang mengganggu perannya sehingga tidak berjalan secara efektif. ${ }^{15}$

Ketidakefektifan penyelesaian sengketa Pilkada di Mahkamah Konstitusi ini diperparah lagi dengan kasus yang menimpa Akil Mochtar, mantan ketua Mahkamah Konstitusi yang divonis seumur hidup oleh Pengadilan Tindak Pidana Korupsi karena kasus suap berkenaan dengan perkara Pilkada yang ditanganinya. Kasus korupsi Akil merupakan salah satu skandal terbesar sepanjang sejarah peradilan di Indonesia karena belum pernah terjadi seorang hakim yang juga Ketua Mahkamah Konstitusi dikenakan hukuman penjara karena terbukti melakukan korupsi dan pencucian uang. Hal ini akan sangat mungkin menciptakan mafia peradilan ${ }^{16}$ baru di Mahkamah Konstitusi yang selama ini dikenal sebagai lembaga peradilan yang bersih. Mafia peradilan sudah dapat dipastikan akan merusak sistem sosial di masyarakat dan menghasilkan putusan yang tidak menjamin keadilan.

Pada akhirnya Mahkamah Konstitusi menghapus kewenangannya dalam menangani 
sengketa Pilkada sebagaimana dalam Putusan No. 97/PUUXI/2013. Dalam pertimbangan hukumnya Mahkamah Konstitusi berpendapat, dalam memahami kewenangan Mahkamah Konstitusi yang ditentukan dalam Pasal 24C ayat (1) UUD NRI 1945, harus kembali melihat makna teks, original intent, makna gramatika yang komprehensif terhadap UUD NRI 1945. Oleh karena itu, pemilihan umum menurut Pasal 22E UUD NRI 1945 harus dimaknai secara limitatif, yaitu pemilihan umum yang diselenggarakan untuk memilih anggota DPR, DPD, Presiden dan Wakil Presiden serta DPRD dan dilaksanakan setiap lima tahun sekali. Berdasarkan putusan tersebut, yang dimaksud pemilihan umum setiap lima tahun sekali pada Pasal 22E UUD NRI 1945 adalah pemilihan umum anggota DPR, DPD, DPRD serta Presiden dan Wakil Presiden secara bersamaan setiap lima tahun sekali. Dengan demikian penambahan kewenangan Mahkamah Konstitusi untuk mengadili perkara perselisihan hasil Pilkada dengan memperluas makna pemilihan umum yang diatur dalam Pasal 22E UUD NRI 1945 adalah inkonstitusional. ${ }^{17}$ Di samping itu latar belakang pembentukan Mahkamah Konstitusi disebabkan oleh adanya kebutuhan untuk melakukan pengujian atas Undang-Undang walaupun dalam perkembangannya kemudian Mahkamah Konstitusi juga diberikan kewenangan lain dalam rangka mengawal konstitusi dan penyelenggaraan Negara berdasarkan prinsip konstitusionalisme. Dalam rangka fungsi dan wewenangnya itulah UUD NRI 1945 mendesain Mahkamah Konstitusi sebagai Mahkamah ketatanegaraan dengan kewenangannya yang spesifik pula, yaitu mengadili perkara-perkara konstitusional sebagaimana disebutkan dalam
Pasal 24C ayat (1) UUD NRI 1945 pada tingkat pertama dan terakhir yang putusannya bersifat final.

\section{Pembaruan Sistem Peradilan Pilkada Menurut Perppu Nomor 1 Tahun 2014}

Perppu Nomor 1 Tahun 2014 kembali mengamanatkan bahwa pemilihan kepala daerah harus dilakukan secara langsung oleh rakyat dengan prinsip-prinsip demokrasi. Perppu ini sekaligus mementahkan Undang-Undang Nomor 22 Tahun 2014 yang mana Pilkada cukup dilaksanakan melalui DPRD di masingmasing provinsi, kabupaten/kota. Dinamika penyelenggaraan Pilkada ini menarik untuk dikaji terutama sistem peradilan perselisihan hasil penghitungan suara. Banyaknya perkara Pilkada yang masuk ke Mahkamah Konstitusi menimbulkan problematika baru dalam pelaksanaannya. Oleh karena itu Perppu Nomor 1 Tahun 2014 yang dikeluarkan oleh Presiden Susilo Bambang Yudhoyono mengatur sistem penyelesaian perselisihan hasil Pilkada secara cepat dan efisien. Perppu ini dikeluarkan dalam rangka menegakkan supremasi hukum dalam konteks kesatuan hukum nasional yang di dalamnya mengatur penyelesaian baik penyelesaian untuk perselisihan hasil Pemilihan Gubernur maupun perselisihan hasil Pemilihan Bupati dan Walikota.

Penyelesaian sengketa hasil Pilkada diatur secara rinci dalam Pasal 156 sampai dengan Pasal 159 Perppu Nomor 1 Tahun 2014. Dalam Pasal 156 ayat (1) perselisihan hasil pemilihan diartikan sebagai perselisihan antara KPU Provinsi dan/atau KPU Kabupaten/ Kota dan peserta Pemilihan mengenai penetapan perolehan suara hasil Pemilihan.

17 Putusan Mahkamah Konstitusi Nomor: 97/PUU-XI/2013. 
Penetapan perolehan yang dimaksud ialah perolehan suara yang signifikan dan dapat mempengaruhi penetapan calon untuk maju ke putaran berikutnya atau penetapan calon terpilih. Apabila terjadi perselisihan penetapan perolehan suara hasil Pemilihan, peserta Pemilihan dapat mengajukan permohonan pembatalan penetapan hasil penghitungan perolehan suara oleh KPU Provinsi dan KPU Kabupaten/Kota kepada Pengadilan Tinggi yang ditunjuk oleh Mahkamah Agung dalam waktu paling lama 3×24 jam sejak diumumkan penetapan perolehan suara hasil Pemilihan oleh KPU Provinsi dan KPU Kabupaten/Kota. Hal ini berarti penyelesaian sengketa hasil Pilkada dikembalikan lagi menjadi kewenangan Mahkamah Agung melalui Pengadilan Tinggi. Mahkamah Agung dalam hal ini menetapkan empat Pengadilan Tinggi yang secara khusus berwenang menangani sengketa hasil Pilkada. Penanganan di Pengadilan Tinggi inipun dilakukan oleh hakim adhoc yang ditetapkan oleh Mahkamah Agung.

Pengajuan permohonan dilengkapi dengan alat bukti dan surat keputusan KPU Provinsi dan KPU Kabupaten/Kota tentang hasil rekapitulasi perhitungan suara pemohon dapat memperbaiki dan melengkapi permohonan paling lama 3 x24 jam sejak diterimanya permohonan oleh Pengadilan Tinggi. Pemberian waktu untuk memperbaiki permohonan ini untuk meminimalisir kesalahan yang menyebabkan permohonan tidak dapat diterima. Penyelesaian di Pengadilan Tinggi tersebut dibatasi waktu paling lama 14 (empat belas) hari sejak diterimanya permohonan. Pembatasan waktu tersebut sebelumnya juga diterapkan ketika masih menjadi kewenangan Mahkamah Konstitusi. Apabila ternyata ada pihak yang tidak menerima Putusan Pengadilan Tinggi dapat mengajukan permohonan keberatan ke Mahkamah Agung paling lama tiga hari sejak putusan Pengadilan Tinggi dibacakan. Mahkamah Agung memutuskan permohonan keberatan paling lama empat belas hari sejak diterimanya permohonan. Putusan Mahkamah Agung tersebut bersifat final dan mengikat sehingga KPU Provinsi dan/atau KPU Kabupaten/Kota wajib menindaklanjuti. Prosedur penanganan perselisihan hasil Pilkada di atas kurang lebih dapat penulis gambarkan sebagai berikut:

Bagan 1. Prosedur penyelesaian hasil Pilkada menurut Perppu Nomor 1 Tahun 2014

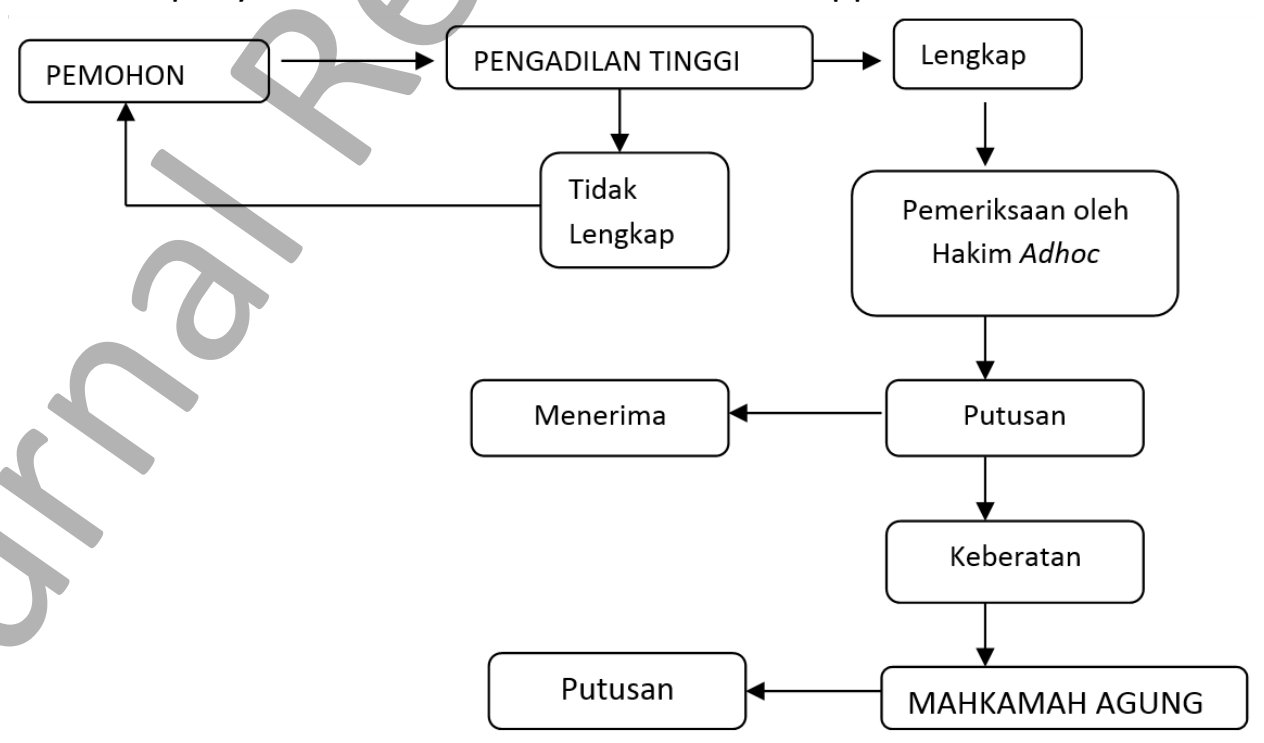


Perbedaan paling mendasar dalam penyelesaian perselisihan hasil Pilkada di atas ialah kewenangan mengadili yang sebelumnya ada di Mahkamah Konstitusi. Di samping itu dalam Perppu nomor 1 Tahun 2014 ini terdapat dua tingkatan peradilan yaitu di Pengadilan Tinggi dan Mahkamah Agung. Pada peraturan sebelumnya penyelesaian sengketa hasil Pilkada hanya terdapat satu tingkatan peradilan yang putusannya bersifat final yaitu di Mahkamah Konstitusi. Sistem penyelesaian tersebut diatur agar sejalan dengan prinsip peradilan yang cepat dan sederhana. Penyelesaian di empat Pengadilan Tinggi yang ditetapkan oleh Mahkamah Agung ini diharapkan efektif karena beban kerja yang dibagi. Sebelumnya semua perkara Pilkada bertumpuk di Mahkamah Konstitusi sedangkan menurut Perppu di atas dibagi ke dalam empat Pengadilan Tinggi yang di dalamnya beranggotakan hakim adhoc. Dengan demikian penambahan tugas Pengadilan Tinggi yang ditetapkan oleh Mahkamah Agung di atas tidak mengganggu tugas utama yaitu memeriksa perkara di tingkat banding.

Namun, dalam perkembangannya mekanisme penyelesaian sengketa yang diatur dalam Perppu Nomor 1 Tahun 2014 tersebut kemudian mengalami perubahan dengan diterbitkannya Undang-Undang Nomor 8 Tahun 2015. Menurut Undang-Undang Nomor 8 Tahun 2015, perkara perselisihan hasil Pemilihan diperiksa dan diadili oleh badan peradilan khusus. Namun, Undang-Undang sendiri tidak menjelaskan secara rinci maksud dari badan peradilan khusus tersebut. Undang-Undang hanya menjelaskan bahwa badan peradilan khusus bertugas menyelesaikan sengketa hasil Pilkada dan dibentuk sebelum pelaksanaan Pilkada serentak. Sebelum terbentuknya badan peradilan khusus ini maka penyelesaian sengketa hasil Pilkada kembali ditangani oleh Mahkamah Konstitusi. Dengan demikian tugas Mahkamah Konstitusi yang sebelumnya menyatakan tidak berwenang menangani perkara Pilkada menjadi panjang. Dibentuknya badan peradilan khusus tersebut merupakan bentuk kemunduran dan ketidakrampingan sistem hukum di Indonesia.

\section{Penyelesaian Pilkada yang Efektif dan Berkeadilan}

Dalam gagasan demokrasi modern, hukum menempati posisiyang sangat sentral. Demokrasi yang diidealkan haruslah diletakkan dalam koridor hukum. Tanpa hukum demokrasi justru dapat berkembang ke arah yang keliru karena hukum dapat ditafsirkan secara sepihak oleh penguasa atas nama demokrasi. ${ }^{18}$ Pengaturan hukum Pilkada diperlukan guna menjamin Pemilihan Gubernur, Bupati,dan Walikota dilaksanakan secara demokratis sebagaimana diamanatkan dalam Pasal 18 ayat (4) UndangUndang Dasar Negara Republik Indonesia Tahun 1945. Indikator demokratis dalam penyelenggaraan Pilkada dapat diukur dari ketaatan penyelenggara Pilkada terhadap asas langsung, umum, bebas, rahasia, jujur, dan adil. Ukuran demokratis lain dalam penyelenggaraan Pilkada dapat diukur dari kemandirian dan integritas penyelenggara Pilkada, yang

18 Jimmly Asshiddiqie. Hukum Tata Negara dan Pilar-Pilar Demokrasi (Jakarta: Konstitusi Press, 2005), hlm. 244. 
mempengaruhi proses penyelenggaraan dan hasil Pilkada itu sendiri. ${ }^{19}$

Selama ini peraturan Pilkada masih dirasa belum dapat berfungsi sebagai aturan main guna membatasi tingkah laku pemilih, pendukung dan kandidat Pilkada. Konsekuensinya, ketentuan perundang-undangan berpotensi besar untuk gagal berfungsi sebagai mekanisme penegakan hukum dalam proses penyelenggaraan Pilkada $^{20}$. Munculnya konflik, pelanggaran dan menumpuknya perkara Pilkada di Mahkamah Konstitusi seakan menjadi bukti bahwa Pilkada menjadi pemicu konflik.Selain itu kualitas penegak hukum dalam penyelesaian sengketa dikeluhkan oleh masyarakat, salah satu penyebabnya karena masih minimnya program untuk peningkatan pemahaman dan kapasitas dalam menangani berbagai pelanggaran Pilkada.

Perbaikan sistem penyelesaian sengketa dilakukan dalam rangka menegakkan hukum Pilkada. Dalam hal ini lembaga peradilan memainkan peranan penting karena merupakan satu-satunya institusi formal yang diberi mandat untuk mengelola segala permasalahan hukum guna mendapatkan keadilan. Lembaga ini pula yang menjadi andalan masyarakat dan bahkan menjadi tumpuan harapan terakhir bagi mereka yang mencari keadilan melalui hukum. ${ }^{21}$ Namun demikian, penyelesaian sengketa di pengadilan seringkali mendapat kritik tajam baik dari praktisi maupun akademisi. Peran dan fungsi peradilan mempunyai beban kerja yang terlampau padat, lama, biaya mahal serta kurang tanggap terhadap kepentingan umum. Perppu Nomor 1 Tahun 2014 sebenarnya telah mengatur sebuah konsep penanganan sengketa hasil Pilkada yang sejalan dengan prinsip peradilan yang cepat dan sederhana. Apabila dilihat secara seksama apa yang diatur dalam Perppu Nomor 1 Tahun 2014 sebenarnya merupakan perbaikan dari sistem yang sebelumnya diatur dalam UndangUndang Nomor 32 Tahun 2004. Namun, sistem yang belum terlaksana tersebut telah kembali mengalami perubahan dengan diterbitkannya Undang-Undang Nomor 8 Tahun 2015.

Dalam Undang-Undang Nomor 32 Tahun 2004 penanganan penyelesaian sengketa hasil Pilkada diselesaikan oleh Mahkamah Agung. Mahkamah Agung dalam melaksanakan kewenangannya ini dapat mendelegasikan kepada Pengadilan Tinggi untuk memutus sengketa hasil penghitungan suara pemilihan kepala daerah dan wakil kepala daerah kabupaten/kota. Sedangkan dalam Perppu penanganannya diselesaikan di Pengadilan Tinggi yang ditunjuk. Mahkamah Agung hanya berwenang untuk memutus permohonan keberatan atas putusan Pengadilan Tinggi.

Penyelesaian di Pengadilan Tinggi ini telah jelas yaitu dengan menggunakan hukum acara dengan batasan waktu yang sangat cepat yaitu hanya empat belas hari. Namun, Mahkamah Agung perlu mengeluarkan peraturan sendiri untuk pelaksanaan secara teknis. Hal yang menarik di sini ialah penyebutan istilah "keberatan" sebagai upaya hukum atas Putusan Pengadilan Tinggi. Sebelumnya dalam Undang-Undang Nomor 32 Tahun 2004 istilah keberatan ke Mahkamah Agung berarti upaya hukum yang diajukan karena tidak menyetujui 
penetapan hasil Pilkada, sehingga Mahkamah Agung bertindak sebagai judex factie. Khusus mengenai sengketa hasil Pilkada di kabupaten/ kota, Mahkamah Agung mendelegasikan kepada Pengadilan Tinggi, sehingga Pengadilan Tinggi yang memeriksa dan memberikan putusan final. Perppu tersebut tidak menggunakan istilah kasasi yang berarti Mahkamah Agung hanya bertindak sebagai judex juris sehingga hanya memeriksa penerapan hukumnya. Menurut penulis adanya upaya hukum keberatan atas putusan Pengadilan Tinggi dalam Perppu Nomor 1 Tahun 2014 nantinya akan memperpanjang proses penyelesaian sengketa Pilkada yang pada akhirnya menimbulkan masalah baru. Hal ini karena setiap Putusan Pengadilan Tinggi pasti akan diajukan upaya hukum ke Mahkamah Agung. Apabila hal ini terjadi maka dapat dipastikan beban kerja Mahkamah Agung semakin bertambah. Menurut Todung Mulya Lubis, Pengadilan Tinggi hendaknya menjadi puncak dari pencarian keadilan. Apabila Mahkamah Agung tetap diberi tugas menerima permohonan kasasi ataupun keberatan pada semua jenis perkara maka Mahkamah Agung akan menjadi pasar jual beli. Di tengah godaan pasar maka putusan Mahkamah Agung juga akan tergantung pada selera pasar. Di sinilah korupsi, kolusi dan nepotisme berkembang biak. ${ }^{22}$ Bahkan sangat mungkin kasus Akil Mochtar akan terulang pada hakim-hakim Agung. Para pencari keadilan (justiciabellen) tentu sangat mendambakan perkara-perkara yang diajukan ke pengadilan dapat diputus oleh hakim-hakim yang profesional dan memiliki integritas moral yang tinggi, sehingga dapat melahirkan putusanputusan yang tidak saja mengandung aspek kepastian hukum (keadilan prosedural), tetapi juga berdimensikan legal justice, moral justice dan social justice.Karena keadilan itulah yang menjadi tujuan utama yang hendak dicapai dari proses penyelesaian sengketa di pengadilan ${ }^{23}$.

Oleh sebab itu Mahkamah Agung sebagaimana disebutkan dalam Pasal 159 ayat (7) harus mengeluarkan Peraturan tersendiri mengenai teknis penyelesaian sengketa. Menurut penulis Peraturan yang dikeluarkan oleh Mahkamah Agung ini paling tidak harus memperhatikan hal-hal sebagai berikut:

a. Penyederhanaan hukum acara yang dipakai dalam persidangan di Pengadilan Tinggi. Selama ini proses beracara di pengadilan baik perdata maupun pidana dianggap terlalu lama karena dianggap terlalu formalistik. Penyederhanaan ini akan membantu hakim dalam penyelesaian sengketa yang menurut peraturan dibatasi hanya empat belas hari. Prinsip peradilan cepat, sederhana, dan murah harus benar-benar diterapkan dalam penyelesaian sengketa hasil Pilkada di Pengadilan Tinggi agar proses peradilan dapat diakses oleh seluruh lapisan masyarakat. Prinsip tersebut berkaitan dengan upaya mewujudkan salah satu unsur Negara hukum, yaitu equality before the law. Apabila proses peradilan berjalan rumit, berbelit-belit, serta membutuhkan biaya yang mahal, maka hanya sekelompok

Todung Mulya Lubis. Catatan Hukum Todung Mulya Lubis Mengapa Saya Mencintai Negeri Ini ? (Jakarta: Penerbit Buku Kompas, 2007), hlm. 83.

23 Bambang Sutiyoso, Metode Penemuan Hukum: Upaya Mewujudkan Hukum Yang Pasti Dan Berkeadilan (Yogyakarta: UII Press, 2009), hlm. 2. 
orang tertentu yang memiliki kemampuan berperkara di pengadilan ${ }^{24}$;

b. Dalam hal pembuktian Mahkamah Agung perlu mengatur macam-macam alat bukti yang dapat diajukan dalam persidangan untuk memudahkan pemohon dalam mempersiapkannya. Selain itu dalam agenda pemeriksaan saksi harus dimungkinkan dilakukannya persidangan jarak jauh (video conference) sebagaimana yang selama ini dilakukan oleh Mahkamah Konstitusi;

c. Adanya pengaturan yang tegas mengenai sifat pelanggaran yang dapat membatalkan hasil Pilkada, misalnya pelanggaran yang bersifat sistematis, terstruktur, dan masif. Pelanggaran tersebut pun harus dapat dibuktikan di persidangan. Ketentuan ini diperlukan agar hakim berhati-hati dalam menjatuhkan putusan;

d. Adanya batasan yang bersifat limitatif untuk pengajuan upaya hukum keberatan ke Mahkamah Agung sehingga tidak semua perkara sengketa Pilkada yang sudah diputus Pengadilan Tinggi dapat diajukan keberatan ke Mahkamah Agung. Pengaturan ini dimaksudkan untuk mengantisipasi menumpuknya perkara di Mahkamah Agung;

e. Pemeriksaan keberatan oleh Mahkamah Agung terhadap Putusan Pengadilan Tinggi hanya mengenai penerapan hukumnya, sehingga Mahkamah Agung di sini jangan sampai berperan sebagai peradilan ulang. Mahkamah Agung harus tetap berperan sebagai judex juris, sehingga tidak perlu memeriksa lagi fakta-fakta yuridis karena hal itu sudah dilakukan oleh Pengadilan Tinggi.

Sistem penyelesaian sengketa Pilkada yang sebelumnya telah diatur dalam Perppu Nomor 1 Tahun 2014 tersebut pada dasarnya sudah memenuhi prinsip penyelesaian sengketa yang efektif dan berkeadilan akan tetapi perlu dilakukan penambahan sebagaimana telah penulis uraikan di atas. Setiap sengketa yang terjadi pasti menuntut penyelesaian yang tepat. Mahkamah Agung dalam hal ini memainkan peranan penting apakah penyelesaian sengketa Pilkada dapat berjalan efektif atau tidak. Keefektifan sistem penyelesaian sengketa Pilkada yang baru ini tergantung dari kualitas dan profesionalitas Mahkamah Agung. Pengadilan Tinggi dan Mahkamah Agung harus menggali keadilan dengan menilai dan mengadili hasil penghitungan yang diperselisihkan. Pelanggaran-pelanggaran yang menyebabkan terjadinya hasil penghitungan suara harus pula dinilai untuk menegakkan keadilan. Dalam memeriksa dan mengadili sengketa hasil Pilkada Pengadilan Tinggi dan Mahkamah Agung harus memperhatikan keadilan substansial (substantial justice) sebagaimana yang dilakukan Mahkamah Konstitusi. Selama ini putusan Mahkamah Konstitusi lebih mendasarkan dan menggunakan pendekatan substantial justice dengan mempersoalkan electoral process. Mahkamah Konstitusi secara tegas menjustifikasi bahwa dirinya mempunyai kewenangan untuk mempersoalkan judicial process untuk memastikan kualitas bukan sekedar kuantitas pemilu dengan menyatakan 
secara materiil telah terjadi pelanggaran ketentuan Pilkada yang berpengaruh pada perolehan suara. ${ }^{25}$ Langkah tersebut merupakan suatu terobosan hukum yang perlu dilakukan untuk memajukan demokrasi dan melepaskan diri dari kebiasaan praktik peradilan yang terlalu prosedural. Aspek keadilan dalam peradilan sangatlah penting dan harus dikedepankan karena menurut ketentuan Pasal 24 ayat (1) UUD NRI 1945 menegaskan bahwa kekuasaan kehakiman merupakan kekuasaan yang merdeka untuk menyelenggarakan peradilan guna menegakkan hukum dan keadilan.

\section{Penutup}

Penyelesaian perselisihan hasil Pilkada sebelum dikeluarkan Perppu Nomor 1 Tahun 2014 menjadi kewenangan Mahkamah Konstitusi berdasarkan Undang-Undang Nomor 12 Tahun 2008 di mana merupakan perluasan makna pemilihan umum sebagaimana diatur dalam Pasal 22E UUD NRI 1945. Kewenangan ini kemudian oleh Mahkamah Konstitusi dianggap inkonstitusional sehingga harus dihapus, namun demikian Mahkamah Konstitusi tetap berwenang mengadili sengketa hasil Pilkada sampai ditetapkan lembaga yang berwenang.

Pembaharuan yang muncul berdasarkan Perppu Nomor 1 Tahun 2014 ialah kewenangan mengadili sengketa hasil Pilkada menjadi kewenangan Pengadilan Tinggi yang ditunjuk oleh Mahkamah Agung. Pengadilan Tinggi tersebut terdiri dari hakim adhoc dan wajib menyelesaikan perkara dalam waktu empat belas hari. Upaya hukum atas putusan Pengadilan Tinggi hanyalah upaya keberatan ke Mahkamah Agung yang putusannya bersifat final dan harus dilaksanakan.

Penyelesaian sengketa hasil Pilkada yang efektif dan berkeadilan dapat dilakukan dengan melakukan penyederhanaan hukum acara. Mahkamah Agung berdasarkan Perppu Nomor 1 Tahun 2014 mengeluarkan Peraturan Mahkamah Agung serta Surat Edaran yang memuat pelaksanaan persidangan dan upaya hukum pembuktian pada sengketa hasil Pilkada. Sejauh mana efektifitas sistem peradilan sengketa Pilkada tersebut tergantung pada ketentuan yang dikeluarkan oleh Mahkamah Agung.

Sistem penyelesaian sengketa hasil Pilkada yang telah diatur dalam Perppu Nomor 1 Tahun 2014 sebenarnya telah memenuhi prinsip penyelesaian yang efektif dan berkeadilan, namun perlu dilakukan perubahan khususnya mengenai penyederhanaan hukum acara;

Berdasarkan Perppu Nomor 1 Tahun 2015 Pengadilan Tinggi yang ditunjuk oleh Mahkamah Agung guna menangani perselisihan hasil Pilkada hendaknya mampu menjangkau seluruh wilayah Indonesia. Pembagian kompetensi relatif empat Pengadilan Tinggi harus dilakukan secara merata meliputi wilayah Indonesia Barat, Tengah, dan Timur. Dengan demikian tidak menyulitkan pemohon selama proses persidangan. Selain itu perlu disediakan sarana penunjang agar persidangan berjalan lancar misalnya fasilitas persidangan jarak jauh sebagaimana sebelumnya telah dilakukan oleh Mahkamah Konstitusi;

Hakim yang dipilih untuk menangani sengketa Pilkada harus profesional dan mengerti

25 Bambang Widjojanto, Kajian Putusan MK Tentang Pemilu \& Pilkada (Jakarta: Kemitraan, 2009), hlm. 6-7 
hukum Pilkada. Pertimbangan ini penting agar jangan sampai hakim adhoc diisi oleh orang yang tidak memahami hukum Pilkada. Proses rekrutmen hakim dilakukan secara cermat dengan memperhatikan rekam jejak serta terlepas dari kepentingan partai politik maupun golongan;

Mahkamah Agung perlu memberikan pelatihan yang intensif terhadap hakim serta pegawai Pengadilan Tinggi yang ditunjuk dengan meningkatkan kompetensi, sehingga penyelesaian sengketa Pilkada dilakukan secara profesional guna memenuhi tuntutan masyarakat;

Peraturan pelaksanaan yang dikeluarkan oleh Mahkamah Agung mengenai penyelesaian sengketa hasil Pilkada agar memperhatikan penyederhanaan hukum acara mengingat waktu penyelesaian yang sangat pendek. Selain pernyederhanaan perlu diatur secara limitatif syarat-syarat permohonan keberatan atas Putusan Pengadilan Tinggi agar tidak semua dapat dimintakan keberatan ke Mahkamah Agung.

\section{DAFTAR PUSTAKA}

\section{Buku}

Asshiddiqie, Jimmly. Hukum Tata Negara dan PilarPilar Demokrasi (Jakarta: Konstitusi Press, 2005)

Edwin, Donni. Pilkada Langsung Demokratisasi Daerah dan Mitos Good Governance ( Jakarta: Partnership dan Pusat Kajian Ilmu Politik, 2004) Ismawan, Indra.Money Politics Pengaruh Uang Dalam Pemilu (Yogyakarta: Media Presindo, 1999)

Lubis, Todung Mulya. Catatan Hukum Todung Mulya Lubis Mengapa Saya Mencintai Negeri Ini ? (Jakarta: Penerbit Buku Kompas, 2007)

Lutfi, Mustafa, Hukum Sengketa Pilkada di Indonesia, Gagasan Perluasan Konstitusional Mahkamah Konstitusi (Yogyakarta: UII Press, 2010)

Madaniy, A Malik, Politik Berpayung Fiqh (Yogyakarta: Pustaka Pesantren, 2010)
MD, Mahfud,Perdebatan Hukum Tata Negara Pasca Amandemen Konstitusi (Jakarta: Pustaka LP3S Indonesia, 2007)

Pradhanawati, Ari.Pilkada Langsung Tradisi Baru Demokrasi Lokal (Surakarta: Pustaka Rumpun Ilalang, 2005)

Rahardjo, Satjipto. Sisi-sisi Lain dari Hukum di Indonesia (Jakarta: Penerbit Buku Kompas, 2003)

Soekanto, Soerjono dan Sri Mahmuji. Penelitian Hukum Normatif (Jakarta: Rajawali Pers, 2007)

Suharizal, Pilkada, Regulasi, Dinamika dan Konsep Mendatang (Jakarta: Raja Grafindo Persada, 2011)

Sutiyoso, Bambang, Metode Penemuan Hukum: Upaya Mewujudkan Hukum Yang Pasti Dan Berkeadilan (Yogyakarta: UII Press, 2009)

Tim Penyusun Hukum Acara Mahkamah Konstitusi, Hukum Acara Mahkamah Konstitusi (Jakarta: Sekretariat Jenderal dan Kepaniteraan Mahkamah Konstitusi RI, 2010)

Widjojanto, Bambang, Kajian Putusan MK Tentang Pemilu \& Pilkada (Jakarta: Kemitraan,2009)

Widoyoko, Danang et.al., Menyingkap Tabir Mafia Peradilan (Jakarta: ICW,2002)

\section{Hasil Penelitian}

Ali, M. Mahrus et. al. Tafsir Konstitusional Pelanggaran Pilkada yang Bersifat Sistematis, Terstruktur, dan Masif (Jakarta: Pusat Penelitian dan Pengkajian Kepaniteraan dan Sekretariat Jenderal Mahkamah Konstitusi Republik Indonesia, 2011)

Maulana Arif, Tinjauan Konstitusional Pengisian Jabatan Kepala Daerah dan Wakil Kepala Daerah Melalui Pemilihan Umum (Tesis). (Jakarta: Universitas Indonesia, 2012)

Satriawan, Iwan et al. Studi Efektifitas Penyelesaian Hasil Sengketa Pilkada Oleh Mahkamah Konstitusi (Jakarta: Pusat Penelitian dan Pengkajian Perkara, Pengelolaan Teknologi Informasi dan Komunikasi Mahkamah Konstitusi Republik Indonesia, 2012)

\section{Makalah/Artikel/Prosiding/Hasil Penelitian}

Asshiddiqie, Jimly, "Demokrasi dan Hak Asasi Manusia" (Makalah disampaikan dalam studium general pada acara The $1^{\text {st }}$ National Converence Corporate Forum for Community Development, Jakarta, 19 Desember 2005) 
Mutiarin, Dyah, Nur Hayati, dan Delina Asriyani:" Analisis Dampak Positif dan Negatif dalam Pilkada Langsung bagi Kualitas Pelayanan Publik di Daerah" (Paper disajikan dalam Forum IImiah Nasional Program Pascasarjana, UMY, 24 Desember 2011)
Simamora, Janpatar, "Eksistensi Pilkada Dalam Rangka Mewujudkan Pemerintahan Daerah yang Demokratis," Mimbar Hukum Volume 23, Nomor 1, (2011)

Sultan, Lomba, "Sistem Pemilihan Umum Kepala Daerah," Al-Fikr Volume 15 Nomor 2 (2011) 
"Halaman ini dikosongkan" 


\title{
PENYELESAIAN PERSELISIHAN HASIL PEMILIHAN KEPALA DAERAH PASCA PUTUSAN MK NO. 97/PUU-XI.2013
}

\author{
(Resolving Disputes on Electoral Result from the Local Election for Regional Leaders \\ after the Verdict of the Constitutional Court No.97/PUU-XI.2013)
}

\author{
Indra Hendrawan \\ Pusat Perencanaan Pembangunan Hukum Nasional \\ Badan Pembinaan Hukum Nasional \\ Jl. Mayjen Sutoyo No. 10 Cililitan Jakarta Timur \\ Email: indra.hukumham@gmail.com
}

Naskah diterima: 19 Januari 2015; revisi: 24 April 2015; disetujui: 30 April 2015

\begin{abstract}
Abstrak
Undang-Undang Nomor 1 Tahun 2015 tentang Penetapan Perpu Nomor 1 Tahun 2014 tentang Pemilihan Gubernur, Bupati dan Walikota Menjadi Undang-Undang mengamanatkan Mahkamah Agung sebagailembaga yang berwenang menyelesaikan perselisihan hasil pemilihan kepala daerah. Namun tanpa sempat diimplementasikan, Undang-Undang tersebut telah direvisi kembali melalui Undang-Undang Nomor 8 Tahun 2015 dengan melimpahkan penyelesaian perselisihan hasil pemilihan ke badan peradilan khusus. Perubahan Undang-Undang secara cepat tersebut telah menimbulkan pertanyaan, kemanakah arah kebijakan penyelesaian perselisihan di masa mendatang? Dengan pendekatan yuridis normative, tulisan ini mencoba menguraikan refleksi penyelesaian perselisihan di Mahkamah Agung ataupun Mahkamah Konstitusi selama satu dasawarsa terakhir untuk mendapatkan penanganan ideal yang harus dilakukan dalam rangka perbaikan penanganan perselisihan hasil pemilihan kepala daerah di masa mendatang. Berdasarkan hal tersebut, penempatan hakim-hakim yang berintegritas, mumpuni serta yang mengedepankan keadilan substantif dalam penyelesaian perselisihan merupakan hal mutlak yang harus dilakukan. Selain itu, perbaikan juga tidak cukup hanya pada tahap penanganan perselisihan hasil saja, perlu pula ada optimalisasi penegakan hukum di tahap-tahap sebelumnya yang dilakukan oleh KPU, Bawaslu/Panwaslu, DKPP ataupun penegak hukum lainnya.
\end{abstract}

Kata kunci: penyelesaian perselisihan, pemilihan kepala daerah, keadilan

\begin{abstract}
Law No. 1 of 2015 on Enactment of Government Regulation in Lieu of Law No. 1 of 2014 concerning the election of Governor, the Regent and Mayor Become Law mandates the Supreme Court as an authorized institution to settle disputes about electoral result from the local election for regional leaders. However, without a chance to be implemented, the Law has been revised by Law No. 8 of 2015 in which any disputes that arise from the results of the election are delegated to a special judicial body. The ammendment has raised question, to where the policy of dispute resolution will be directed in the future? Using normative juridical approach, this paper tries to elaborate the reflection of dispute resolution in the Supreme Court or the Constitutional Court during the last decade to find out ideal treatment should be applied in order to improve the dispute resolution mechanism in the future. So, the placement of judges who have integrity, capability, and put the substantive fairness in the dispute resolution is absolute term. In addition, the improvement is not enough in just handling the dispute resolution stage, there should also be optimizing of the the law enforcement in the earlier stages that were carried out by the General Election Commission, Bawaslu/Panwaslu, DKPP or other law enforcement bodies.
\end{abstract}

Keywords: dispute, local elections for regional leaders, justice 


\section{A. Pendahuluan}

Penangkapan

Ketua

Mahkamah

Konstitusi (MK) Akil Mochtar terkait suap perselisihan hasil pemilihan kepala daerah telah menghancurkan wibawa MK sebagai penjaga konstitusi. Kepentingan politik dan ekonomi yang begitu kental menjadi tantangan tersendiri bagi siapapun yang menangani perselisihan hasil pemilihan. MK sebagai produk hasil reformasi yang sempat diagungagungkan independensinya tidak mampu untuk mengatasi rawannya perkara dari "permainan kotor". Para pihak yang berperkara berusaha menyuap hakim yang memeriksa perkara untuk memenangkan pemilihan walaupun harus mengeluarkan modal yang banyak.

Penanganan perkara pemilihan kepala daerah kembali berpolemik ketika MK mengabulkan permohonan tentang pengujian Pasal 236C Undang-Undang Nomor 12 Tahun 2008 tentang Pemerintahan Daerah dan Pasal 29 ayat (1) huruf e Undang-Undang Nomor 48 Tahun 2009 tentang Kekuasaan Kehakiman terkait kewenangan MK mengadili perselisihan hasil Pilkada. Pengujian ini berakhir dengan putusan MK No. 97/PUU-XI.2013 yang mengabulkan seluruh permohonan para pemohon walaupun disertai dengan dissenting opinion dari 3 (tiga) hakim MK lainnya.

MK menilai bahwa kedua pasal itu bertentangan dengan UUD NRI Tahun 1945. Penambahan kewenangan MK untuk mengadili perselisihan hasil pemilihan kepala daerah dengan memperluas makna pemilu seperti diatur Pasal 22E UUD NRI Tahun 1945 adalah inkonstitusional. Pemilu menurut Pasal 22E UUD NRI Tahun 1945 harus dimaknai secara limitatif untuk memilih anggota DPR, DPD, DPRD, presiden dan wakil presiden yang dilaksanakan lima tahun sekali, jika memasukkan pemilihan kepala daerah menjadi bagian dari pemilu dan menjadi kewenangan MK maka tidak sesuai dengan makna original intent dari pemilu.

Undang-Undang Nomor 1 Tahun 2015 tentang Penetapan Perpu No 1 Tahun 2014 tentang Pemilihan Gubernur, Bupati dan Walikota Menjadi Undang-Undang seolah menjadi jawaban atas ketidakpastian lembaga manakah yang berwenang menyelesaikan perselisihan hasil Pilkada. Pasal 159 menyatakan bahwa penyelesaian perselisihan hasil pemilihan ditangani oleh hakim adhoc di Pengadilan Tinggi yang ditetapkan oleh Mahkamah Agung (MA). Berdasarkan pasal tersebut, Undang-Undang menghendaki lembaga yang berwenang untuk menyelesaikan perselisihan hasil Pilkada adalah MA.

Penafsiran Pasal 22E UUD NRI Tahun 1945 memang sulit untuk mempertahankan penanganan perselisihan tetap berada di MK, mengingat wewenang dan kewajiban MK secara rinci dan limitative diatur dalam konstitusi sehingga tidak ada lagi peluang penambahan atau pengurangan wewenang MK melalui peraturan perundang-undangan dibawah konstitusi, berbeda dengan MA yang wewenangnya masih terbuka untuk ditambah melalui Undang-Undang ${ }^{1}$. Putusan MK juga harus dihormati sebagai Putusan yang final dan mengikat apapun perdebatannya, apabila kewenangan ingin dikembalikan lagi ke MK, harus ada Putusan MK kembali yang menyatakan dirinya berwenang atau terlebih dahulu harus ada amandemen UUD NRI Tahun 
1945 yang memperjelas "gender" pemilihan kepala daerah.

Keberlakuan Undang-Undang Nomor 1 Tahun 2015 ternyata tidak berlangsung lama, pada tanggal 18 Februari 2015 rapat paripurna DPR merevisi Undang-Undang tersebut melalui Undang-Undang Nomor 8 Tahun 2015. Kini, perkara perselisihan hasil pemilihan diperiksa dan diadili oleh badan peradilan khusus, selama badan peradilan khusus tersebut belum terbentuk maka penanganan perkara perselisihan hasil pemilihan dilakukan oleh MK. Dengan saling berpindahnya kewenangan lembaga yang berhak menangani perselisihan hasil pemilihan menjadi pertanyaan besar kemanakah arah kebijakan penanganan sengketa hasil pemilihan ini?, apakah di MK atau MA ataukah badan peradilan khusus?

Penanganan perselisihan pemilihan menjadi menarik untuk dikaji mengingat perkara ini bukanlah hal yang baru dalam pengalaman hukum bangsa ini, perselisihan hasil pemilihan telah satu dasawarsa ditangani baik oleh MA ataupun MK, oleh karena itu banyak pembelajaran yang dapat dipetik dari pengalaman tersebut. Apakah MK atau MA atau badan peradilan khusus yang menangani perselisihan hasil pemilihan, hal yang penting dari semua itu adalah harus ada perbaikan model penyelesaian perselisihan hasil pemilihan kepala daerah.

Berdasarkan hal tersebut, akan dibahas lebih jauh tentang bagaimanakah gambaran/ refleksi penanganan perselisihan hasil pemilihan kepala daerah selama satu dasawarsa terakhir? serta bagaimanakah lembaga dan optimalisasi penanganan ideal yang harus dilakukan dalam rangka perbaikan penanganan perselisihan hasil pemilihan kepala daerah di masa mendatang.

\section{B. Metode Penelitian}

Berdasarkan ruang lingkup masalah sebagaimana telah diuraikan, penelitian ini menggunakan tipe penelitian yuridis normative (normative legal research), yaitu penelitian yang ditujukan untuk meneliti asas-asas hukum, sistematika hukum, sinkronisasi peraturan perundang-undangan secara vertical dan horizontal, perbandingan hukum dan sejarah hukum², dengan demikian penelitian ini menitikberatkan pada alat pengumpulan data sekunder berupa studi dokumen atau bahan pustaka.

Bahan hukum yang digunakan sebagai sumber utama yaitu bahan hukum primer berupa peraturan perundang-undangan dan yurisprudensi antara lain peraturan perundangundangan terkait pemilihan kepala daerah serta Putusan Mahkamah Agung dan Putusan Mahkamah Konstitusi yang terkait dengan penanganan perselisihan hasil pemilihan kepala daerah. Sedangkan bahan hukum sekunder yang digunakan yaitu buku-buku, karya ilmiah dan hasil penelitian yang berkaitan dengan objek yang dibahas. Pengumpulan data dilengkapi pula dengan artikel hukum dari internet ataupun artikel ilmiah lainnya yang dapat mendukung pengayaan data dalam penelitian ini. Pengolahan data atau analisa dilakukan secara kualitatif dimana penyajian data dilakukan sekaligus dengan analisanya ${ }^{3}$.

Soerjono Soekanto, Pengantar Penelitian Hukum, (Jakarta, UI Press, 2010), hal 40.

Ibid, hal 41. 


\section{Pembahasan}

1. Refleksi Satu Dasawarsa Penyelesaian Perselisihan Hasil Pilkada

a. Penanganan Sengketa Hasil Pilkada berdasarkan Undang-Undang Nomor 32 Tahun 2004 tentang Pemerintahan Daerah

\section{1) Pengaturan Hukum Penyelesaian Sengketa Hasil Pilkada}

Sejak berlakunya Undang-Undang Nomor 32 Tahun 2004 tentang Pemerintahan Daerah, pilkada pertama kali diselenggarakan pada bulan Juni 2005. Terkait penanganan sengketa hasil pilkada, pengaturannya didasarkan Pasal 106 Undang-Undang Nomor 32 Tahun 2004 Tentang Pemerintahan Daerah, yang berisi:

ayat (1): keberatan terhadap penetapan hasil pemilihan kepala daerah dan wakil kepala daerah hanya dapat diajukan oleh pasangan calon kepada Mahkamah Agung dalam waktu paling lambat 3 (tiga) hari setelah penetapan hasil pemilihan kepala daerah dan wakil kepala daerah.

ayat (2): keberatan sebagaimana dimaksud pada ayat (1) hanya berkenaan dengan hasil perhitungan suara yang mempengaruhi terpilihnya pasangan.

ayat (3): pengajuan keberatan kepada Mahkamah Agung sebagaimana dimaksud pada ayat (1) disampaikan kepada pengadilan tinggi untuk pemilihan kepala daerah dan wakil kepala daerah provinsi dan kepada pengadilan negeri untuk pemilihan kepala daerah dan wakil kepala daerah kabupaten/kota.

ayat (4): Mahkamah Agung memutus perselisihan hasil penghitungan suara sebagaimana dimaksud pada ayat (1) dan ayat (2) paling lambat 14 (empat belas) hari sejak diterimanya permohonan keberatan oleh Pengadilan Negeri/ Pengadilan Tinggi/Mahkamah Agung. ayat (5): Putusan Mahkamah Agung sebagaimana dimaksud pada ayat (4) bersifat final dan mengikat.

ayat (6): Mahkamah Agung dalam melaksanakan kewenangannya sebagaimana dimaksud pada ayat (1) dapat mendelegasikan kepada Pengadilan Tinggi untuk memutus perselisihan perhitungan suara pemilihan kepala daerah dan wakil kepala daerah kabupaten dan kota.

Dalam peraturan pelaksanaannya, ketentuan Pasal 106 tersebut kembali diulang secara utuh dalam Pasal 94 PP No. 6 Tahun 2005 Tentang Pemilihan, Pengesahan, Pengangkatan dan Pemberhentian Kepala Daerah dan Wakil Kepala Daerah. Sedangkan mengenai prosedur acara pemeriksaan di MA maupun Pengadilan Tinggi diatur dalam Perma No. 2 Tahun 2005 tentang Tata Cara Pengajuan Upaya Hukum Keberatan terhadap Penetapan Hasil Pilkada dan Pilwakada Dari KPUD Provinsi dan KPUD Kabupaten/Kota.

Pengajuan upaya hukum keberatan di dalam Pasal 3 ayat (1) Perma No.2 Tahun 2005 berbunyi "Keberatan terhadap penetapan hasil pemilihan kepala daerah dan wakil kepala daerah provinsi atau kab/kota hanya dapat diajukan berkenaan dengan hasil penghitungan suara yang mempengaruhi terpilihnya pasangan calon", kemudian di dalam ayat (5) memperjelas bahwa "Keberatan yang diajukan oleh pemohon atau kuasa hukumnya wajib menguraikan dengan jelas dan rinci tentang:

a) Kesalahan dari penghitungan suara yang diumumkan oleh KPUD dan hasil penghitungan suara yang benar menurut pemohon;

b) Permintaan untuk membatalkan hasil penghitungan suara yang diumumkan KPUD dan menetapkan hasil penghitungan suara yang benar menurut pemohon; 
Terkait dengan putusan yang dapat dikeluarkan oleh Mahkamah Agung atau Pengadilan Tinggi diatur di dalam Pasal 4 bahwa Putusan berisi:

a) Permohonan keberatan tidak dapat diterima;

b) Menolak permohonan keberatan;

c) Mengabulkan permohonan keberatan dengan menyatakan membatalkan hasil penghitungan suara yang ditetapkan oleh KPUD dan menetapkan hasil perhitungan suara yang benar ${ }^{4}$.

Penanganan sengketa hasil pilkada selama ditangani oleh MA telah menyelesaikan sebanyak 98 perkara, yang terdiri dari 74 perkara kasasi dan 24 perkara peninjauan kembali (PK). Perkara tersebut diselesaikan sejak tahun 2005 hingga 2008. Dari jumlah tersebut, hanya empat perkara yang permohonannya dikabulkan MA. Sisanya ditolak 5 .

Secara umum, permohonan yang ditolak adalah karena pemohon tidak pernah mampu membuktikan adanya kesalahan penghitungan suara. Banyak permohonan diajukan dengan alasan yang berada di luar kompetensi pengadilan berupa pelanggaran-pelanggaran yang sudah dilakukan sejak awal proses pentahapan pilkada, seperti:

a) Surat suara yang tidak didistribusikan kepada yang berhak;

b) Menghalangi massa atau pendukung calon tertentu untuk menggunakan hak pilihnya;

c) Tidak membagikan kartu pemilih dan surat panggilan untuk memilih; d) Para calon telah memberikan iming-iming uang kepada para pemilihnya (money politic) dan janji-janji tertentu (kontrak politik);

e) Pelanggaran saat kampanye;

f) Pembakaran surat suara;

g) Pencoblosan surat suara oleh anak-anak dibawah umur untuk menggelembungkan jumlah suara ${ }^{6}$.

\section{2) Contoh Kasus Penanganan Sengketa Hasil Pilkada di MA.}

Penanganan sengketa yang dilakukan oleh MA terbatas pada penyelesaian sengketa hasil pilkada serta dengan tegas menolak untuk mengadili sengketa diluar dari hasil pilkada, di dalam Undang-Undang Nomor 32 Tahun 2004 telah jelas disebut bahwa keberatan itu berkenaan dengan penghitungan suara yang mempengaruhi terpilihnya pasangan calon saja, karena itu pemeriksaan hanya diarahkan pada persoalan rekapitulasi penghitungan suara tersebut.

Salah satu contoh yang cukup menarik dari putusan hasil penyelesaian sengketa tersebut adalah penyelesaian sengketa hasil pilkada Kota Depok. Surat Penetapan dari KPUD Depok No.18 Tahun 2005 telah memenangkan pasangan calon Nur Mahmudi-Yuyun dengan hasil rekapitulasi KPUD untuk pasangan Nur Mahmudi-Yuyun sebesar 232.610 suara sedangkan pasangan Badrul-Syihabudin sebesar 206.781 suara, selisih diantara mereka adalah sebesar 25.829 suara.

Pasangan calon Walikota Badrul-Syihabudin menyatakan keberatannya dengan mengajukan

$4 \quad$ Peraturan Mahkamah Agung No.2 Tahun 2005.

$5 \quad$ Hukumonline.com, MA resmi limpahkan sengketa hasil pilkada ke MK, diakses tanggal 5 Januari 2014.

6 Paulus Effendi Lotulung, Aspek Yuridis dalam masalah Sengketa Pilkada, (LPP HAN, 2005), hal x. 
perkara tersebut ke Pengadilan Tinggi Jawa Barat. Atas dasar pengajuan permohonan sengketa hasil pilkada, Pengadilan Tinggi Jabar dalam amar putusannya memutuskan?:

a) mengabulkan permohonan dari Pemohon (Badrul-Syihabudin).

b) menyatakan batal hasil perhitungan suara akhir yang diumumkan oleh KPUD Depok.

c) Menyatakan jumlah perhitungan yang benar adalah: Untuk calon pasangan Nomor 3 (Badrul-Syihabudin) perolehan suara menjadi 269.551 suara dan untuk calon pasangan Nomor 5 (Nur Mahmudi-Yuyun) perolehan suara menjadi 204.828 suara.

Hasil putusan ini mengundang banyak polemik baik dari kalangan politik, praktisi ataupun akademis, putusan dari Pengadilan Tinggi Jabar dinilai tidak berdasarkan hukum dan fakta, putusan itu cacat hukum secara formal dan materiil sehingga harus dikatakan batal demi hukum.

Pada dasarnya pemeriksaan keberatan penghitungan hasil suara di Pengadilan Tinggi Jabar diajukan dengan alasan yang hampir serupa dengan kasus perselisihan pilkada lainnya, tetapi yang menarik pada kasus ini Pengadilan Tinggi mengabulkan permohonan yang diajukan. Pengadilan menyatakan sekitar 60.000 suara yang diklaim pemohon (BadrulSyihabudin) disetujui tanpa lebih dulu ada pemeriksaan yang pasti apakah suara itu memang benar memilih pemohon. Oleh karena itu, disinyalir dalam persidangan ini terdapat penyimpangan prosedur beracara.

Atas dasar berbagai kejanggalan tersebut pihak Nur Mahmudi-Yuyun mengajukan upaya hukum luar biasa Peninjauan Kembali ke MA, namun menjadi pertanyaan pada saat itu, apakah Putusan Pengadilan Tinggi Jabar dapat diperiksa mengingat berdasarkan Undang-Undang Nomor 32 Tahun 2004, PP No.6 tahun 2005 dan Perma No.2 Tahun 2005, keseluruhannya menyebutkan bahwa putusan Pengadilan Tinggi bersifat Final dan Mengikat.

Menjawab polemik tersebut, pada akhirnya MA berpendapat bahwa pengajuan tersebut dapat dibenarkan dan mengabulkan permohonan PK karena Pengadilan Tinggi dinilai telah melakukan kekeliruan dalam menerapkan hukum, dengan alasan sebagai berikut ${ }^{8}$ :

a) Bahwa yang menjadi wewenang MA atau Pengadilan Tinggi dalam memeriksa dan mengadili perselisihan hasil Pilkada adalah hanya terhadap penetapan hasil pemilihan yang berkenaan dengan hasil penghitungan suara yang mempengaruhi terpilihnya pasangan calon.

b) Bahwa konsekuensi diajukan keberatan dalam perselisihan hasil Pilkada adalah kewajiban dari Pemohon untuk membuktikan adanya kehilangan suara Pemohon, pembuktian tersebut tentunya harus berdasarkan alat bukti yang sah dan menurut hukum acara perdata, bukan berdasarkan pada dugaan atau asumsi yang tidak dapat menjadi alat bukti yang sempurna, hasil akhir penghitungan suara tidak dapat digagalkan oleh hal-hal yang bersifat teknis dalam pelaksanaan pemilihan karena tentang hal tersebut bukan merupakan wewenang MA untuk menyelesaikannya.

c) Bahwa alat-alat bukti yang diajukan oleh Termohon Peninjauan Kembali menurut pendapat MA selain tidak ada yang dapat

Putusan Pengadilan Tinggi Jawa Barat No.01/PILKADA/2005/PT.Bdg.

$8 \quad$ Putusan Mahkamah Agung Nomor 01 PK/PILKADA/2005. 
membuktikan adanya kehilangan suara yang signifikan yang dapat mempengaruhi penetapan hasil penghitungan suara, selain itu alat bukti tersebut hanya berkenaan dengan teknis dalam penyelenggaraan pemilihan, yang untuk memeriksa dan memutusnya bukan menjadi wewenang MA maupun Pengadilan Tinggi.

Pada prinsipnya, langkah yang telah diambil MA untuk menyidangkan Peninjauan Kembali perselisihan hasil pilkada Kota Depok merupakan terobosan hukum dalam rangka menjaga rasa keadilan di dalam masyarakat, selain itu MA juga menjaga garis ketentuan bahwa penyelesaian perselisihan yang dapat diadili oleh Pengadilan Tinggi ataupun MA hanyalah yang terkait dengan perselisihan hasil suara pemilihan, lebih dari itu yang terkait dengan penyelenggaraan pemilihan bukanlah menjadi kewenangan Pengadilan Tinggi ataupun $M A$, prinsip ini yang menurut MA telah terjadi "kesalahan yang nyata" dalam menerapkan hukum yang telah dilakukan oleh Pengadilan Tinggi Jabar dalam menangani perselisihan hasil pilkada Kota Depok.

Contoh kasus lain yang dapat mempertegas karakteristik model penyelesaian perselisihan di MA dapat pula dilihat pada kasus pilkada provinsi Sulawesi Selatan. Putusan Kasasi MA No.02P/KPUD/2007 telah memerintahkan pemungutan suara ulang di 4 kabupaten di Sulawesi Selatan. Namun demikian, melalui Putusan PK, MA menganulir pelaksanaan pemungutan suara ulang yang telah dilakukan tersebut. MA menganggap putusan tersebut sebagai "kesalahan yang nyata" yang telah dilakukan oleh Majelis Hakim. Putusan yang dapat dikeluarkan oleh MA terkait penanganan perselisihan hasil pilkada hanya dapat berupa permohonan keberatan tidak dapat diterima, mengabulkan permohonan atau menolak permohonan.

b. Penanganan Perselisihan Hasil Pilkada berdasarkan Undang-Undang Nomor 12 Tahun 2008 tentang Perubahan Kedua Undang-Undang Nomor 32 Tahun 2004 tentang Pemerintahan Daerah.

\section{1) Pengaturan Hukum Penyelesaian Perselisihan Hasil Pilkada}

Pembahasan penanganan perselisihan hasil pilkada berdasarkan Undang-Undang Nomor 12 Tahun 2008 tidak dapat terlepas dari keberlakuan Undang-Undang Nomor 22 Tahun 2007 tentang Penyelenggara Pemilihan Umum. Berdasarkan Undang-Undang ini terjadi beberapa transformasi seputar hukum Pilkada, antara lain;

a) Pilkada (selanjutnya disebut Pilkada) dimasukkan dalam rezim pemilu, hal ini ditandai dengan dimasukkannya pengaturan mengenai pilkada di dalam Undang-Undang Nomor 22 Tahun 2007 sehingga secara resmi bernama Pemilihan Umum Kepala Daerah dan Wakil Kepala Daerah atau disingkat Pilkada.

b) Perubahan pemaknaan pilkada dari rezim Pemerintahan Daerah ke rezim pemilu di dalam Undang-Undang Nomor 22 Tahun 2007 membawa implikasi dikemudian hari dengan diserahkannya penanganan perselisihan hasil Pilkada dari MA ke MK melalui Undang-Undang Nomor 12 tahun 2008.

Secara umum, penanganan perselisihan hasil Pilkada, pengaturannya dilandasi berdasarkan Pasal 236 C Undang-Undang Nomor 12 Tahun 2008 tentang Pemerintahan Daerah, yang berisi: 
"Penanganan perselisihan hasil penghitungan suara pemilihan kepala daerah dan wakil kepala daerah oleh Mahkamah Agung dialihkan kepada Mahkamah Konstitusi paling lama 18 (delapan belas) bulan sejak UU ini diundangkan"

Dasar peralihan kewenangan penyelesaian perselisihan pilkada dari MA ke MK berdasarkan tinjauan dari sisi penyelenggara pemilu tercantum dalam Pasal 1 Butir 5 UndangUndang Nomor 22 Tahun 2007 yang berbunyi "Penyelenggara Pemilihan Umum adalah lembaga yang menyelenggarakan Pemilu untuk memilih anggota DPR,DPD, DPRD, Dan Presiden dan Wakil Presiden, serta kepala daerah dan wakil kepala daerah secara langsung oleh rakyat" selanjutnya di dalam Pasal 1 Butir 7 diperjelas kembali bahwa "Komisi Pemilihan Umum Provinsi dan Komisi Pemilihan Umum kabupaten/Kota, selanjutnya disebut KPU Provinsi dan KPU Kabupaten/Kota adalah Penyelenggara Pemilu di provinsi dan Kabupaten/Kota".

Sebelum Undang-Undang Nomor 22 Tahun 2007 diterbitkan, Pilkada diselenggarakan di bawah rezim pemerintahan daerah dan perselisihan hasil Pilkada diserahkan kepada MA. Setelah terbitnya Undang-Undang Penyelenggara Pemilu, Pilkada dianggap sebagai bagian dari pemilu, kewenangan penyelenggaraan Pilkada menjadi ranah dari KPU sehingga KPU berwenang untuk membuat regulasi tentang Pilkada di bawah Undang-Undang dan perselisihan Pilkada harus diserahkan dari MA ke MK. Peralihan kewenangan tersebut didasarkan pada Pasal 24C UUD NRI Tahun 1945 bahwa institusi yang memiliki kewenangan untuk memutus perselisihan tentang hasil pemilihan umum adalah Mahkamah Konstitusi.

Undang-Undang Nomor 12 Tahun 2008 tentang Perubahan Kedua Undang-Undang Nomor 32 Tahun 2004 tentang Pemerintahan Daerah sesungguhnya telah membawa semangat perubahan ini, oleh karena itu munculnya Pasal 236 C Undang-Undang Nomor 12 Tahun 2008 hanya untuk menegaskan sekaligus sebagai dasar hukum peralihan kewenangan penyelesaian perselisihan hasil Pilkada.

Teknis penyelesaian perselisihan hasil Pilkada tidak seluruhnya lagi diatur dalam PP No.6 Tahun 2005, tata cara penyelesaian perselisihan Pilkada kini diatur langsung melalui:

a) Hukum acara MK sebagaimana diatur dalam Undang-Undang Nomor 24 Tahun 2003, yang merupakan hukum acara yang bersifat umum di dalam MK;

b) Peraturan Mahkamah Konstitusi No 15 Tahun 2008 tentang Pedoman Beracara Dalam Perselisihan Hasil Pemilihan Umum Kepala Daerah yang merupakan hukum acara yang bersifat khusus.

\section{2) Contoh Kasus Penanganan Perselisihan Hasil Pilkada di MK}

Berdasarkan beberapa putusan yang telah dikeluarkan oleh MK terlihat jelas ada perubahan karakteristik secara mendasar antara penanganan perselisihan ketika masih ditangani oleh MA dan penanganan ketika sudah ditangani oleh MK.

Perbedaan karakter tersebut juga dapat dilihat dari makna pengujian yang berbeda antara dua institusi tersebut. MK melakukan pengujian konstitusionalitas (the constitutional 
of legislative law or legis/ation), sedangkan MA melakukan pengujian legalitas (the legality of regulation) ${ }^{9}$.

Salah satu contoh kasus yang dapat memberikan gambaran tersebut dapat dilihat dari Putusan Mahkamah Konstitusi No. 41/ PHPU.D-VI/2008 yang memutus perselisihan hasil perolehan suara dalam Pilkada provinsi Jawa Timur. Perselisihan tersebut secara ringkas mengenai pasangan Khofifah Indar Parawansa dan Mujiono (Kaji) yang menggugat hasil penghitungan suara pilgub Jatim oleh KPU Provinsi Jatim dengan hasil Khofifah-Mujiono (Kaji) 7.669.721 suara dan Soekarwo-Saifullah Yusuf (Karsa) 7.729.994 suara. Pemohon menilai terdapat kesalahan penghitungan suara secara sistematis di 25 kabupaten/kota di Jatim, dan mengklaim hasil yang benar adalah Kaji 7.654.742 suara dan Karsa 7.632.281 suara.

Amar putusan yang dikeluarkan oleh majelis hakim dalam persidangan tersebut adalah mengabulkan permohonan untuk sebagian, membatalkan dan menyatakan tidak mengikat secara hukum Keputusan KPU Provinsi Jawa Timur serta memerintahkan kepada KPU Provinsi Jawa Timur:

a) Pemungutan suara ulang Pemilu Kepala Daerah dan Wakil Kepala Daerah Prov. Jawa Timur Putaran II di Kab. Bangkalan dan Kab. Sampang dalam waktu paling lambat 60 hari sejak Putusan ini diucapkan;

b) Penghitungan suara ulang Pemilu Kepala Daerah dan Wakil Kepala Daerah Prov. Jawa Timur Putaran II di Kab. Pamekasan dengan menghitung kembali secara berjenjang surat suara yang sudah dicoblos dalam waktu paling lambat 30 hari sejak Putusan ini diucapkan ${ }^{10}$;

Perintah untuk melakukan penghitungan suara ulang ini sebelumnya tidak pernah diperkenankan ketika perselisihan pilkada masih ditangani oleh MA.

Berdasarkan pada kasus perselisihan Pilkada di Jawa Timur, menarik untuk dikaji bagaimana MK menilai permasalahan tersebut melalui ikhtisar pertimbangan hukum MK sebagai berikut ${ }^{11}$ :

a) Secara materiil telah terjadi pelanggaran ketentuan Pilkada yang berpengaruh terhadap perolehan suara kedua Pasangan Calon Kepala Daerah dalam Pilkada Provinsi Jawa Timur Putaran II;

b) Pelanggaran sistematis, terstruktur dan masif yang terjadi di daerah pemilihan Kab. Sampang, Kab. Bangkalan, dan Kab. Pamekasan yang bertentangan dengan konstitusi khususnya pelaksanaan Pilkada secara demokratis, terbukti secara sah dan meyakinkan, sehingga oleh karenanya Pasangan Calon yang terbukti melakukan pelanggaran tidak boleh diuntungkan oleh pelanggarannya, dan sebaliknya Pasangan Calon lainnya tidak boleh dirugikan;

c) Keputusan KPU Provinsi Jawa Timur tentang Rekapitulasi Hasil Penghitungan Suara Pilkada Provinsi Jawa Timur Putaran II harus dinyatakan batal dan tidak mempunyai kekuatan hukum mengikat sepanjang mengenai Hasil Penghitungan Suara di Kabupaten yang terkena dampak pengaruh pelanggaran dimaksud;

\footnotetext{
9 Jimly Asshiddiqie, Hukum Acara Pengujian Undang-Undang, (Jakarta: Yarsif Watampone, 2005), hlm. 5.

10 Putusan Mahkamah Konstitusi No. 41/PHPU.D-VI/2008.

11 Loc.cit.
} 
d) Dalam mengadili perkara ini, Mahkamah tidak dapat dipasung hanya oleh ketentuan UU yang ditafsirkan secara sempit, yakni bahwa Mahkamah hanya boleh menilai hasil Pilkada dan melakukan penghitungan suara ulang dari berita acara atau rekapitulasi yang dibuat secara resmi oleh KPU Provinsi Jawa Timur, sebab kalau hanya berpedoman pada hasil penghitungan suara formal yang dibuat oleh Termohon tidak mewujudkan kebenaran materiil sehingga akan sulit ditemukan keadilan;

e) Untuk menegakkan keadilan substantif dan untuk memberi manfaat dalam penegakan demokrasi dan konstitusi yang harus dikawal oleh Mahkamah, dengan mempertimbangkan semua alat bukti yang diajukan dalam persidangan, maka Mahkamah dapat memerintahkan pemungutan suara ulang dan/atau penghitungan suara ulang di kabupaten dan/atau bagian tertentu lainnya di wilayah pemungutan suara dalam perkara a quo;

f) Manfaat yang dapat diperoleh dari putusan yang demikian adalah agar pada masamasa yang akan datang, pemilihan umum pada umumnya dan Pilkada khususnya, dapat dilaksanakan dengan asas langsung, umum, bebas, rahasia, jujur, dan adil tanpa dicederai oleh pelanggaran serius, terutama yang sifatnya sistematis, terstruktur, dan masif. Pilihan Mahkamah yang demikian masih tetap dalam koridor penyelesaian perselisihan hasil Pilkada dan bukan penyelesaian atas proses pelanggarannya sehingga pelanggaran-pelanggaran atas

proses itu sendiri dapat diselesaikan lebih lanjut melalui jalur hukum yang tersedia;

g) Memerintahkan Termohon (KPU Provinsi Jawa Timur) untuk melaksanakan pemungutan suara ulang dan penghitungan suara ulang di Kabupaten yang akan disebut dalam amar putusan;

Pengalihan kewenangan dari MA ke MK telah memberi sifat dan karakter yang berbeda, disatu sisi undang-undang telah menegaskan bahwa kewenangan MK adalah memutus perselisihan tentang hasil pemilihan dan persoalan perselisihan penyelenggaraan pemilu sudah ada mekanisme proseduralnya. Namun, MK menyatakan, perselisihan dimaknai bukan hanya sebagai masalah "kuantitas" rekapitulasi hasil suara saja, namun juga menyangkut kualitas pemilu dengan menyatakan secara materiil telah terjadi pelanggaran ketentuan Pilkada yang berpengaruh pada perolehan suara, Mahkamah juga membuat kualifikasi apakah pelanggaran itu bersifat sistematis, terstruktur dan masif. ${ }^{12}$

Secara keseluruhan, putusan perkara di MK telah membebaskan diri dari konstruksi normatif awal yaitu peradilan kesalahan penghitungan suara menjadi peradilan konstitusional penyelenggaraan pemilu, berdasarkan hal itu putusan-putusan perkara mencoba memenuhi prinsip hukum progresif. Yurisprudensi dalam putusan MK memunculkan prinsip-prinsip hukum baru dalam perkara perselisihan hasil Pilkada, yaitu ${ }^{13}$ :

a) Prinsip kebenaran materiil mengatasi kebenaran formil.

b) Prinsip keputusan dalam proses demokrasi dapat dibatalkan pengadilan.

12 Bambang widjojanto, Kajian Putusan MK tentang Pemilu \& Pilkada,(Jakarta:Kemitraan, 2009), hlm. 7

13 Janedjri M Gaffar, Hukum Pemilu dalam Yurisprudensi Mahkamah Konstitusi, (Jakarta: Konstitusi Pres, 2013), hlm. 204 
c) Prinsip perlindungan hak konstitusional warga negara.

d) Prinsip memperhatikan perkembangan masyarakat.

\section{c. Perbandingan Pengaturan Hukum Penyelesaian Perselisihan Hasil Pemilihan Kepala Daerah.}

Perpu No.1 Tahun 2014 yang kemudian disahkan oleh DPR menjadi Undang-Undang Nomor 1 Tahun 2015, didahului dengan keluarnya Putusan Mahkamah Konstitusi No. 97/PUU-XI/2013 tentang pengujian Pasal 236 C Undang-Undang Nomor 12 Tahun 2008 tentang Pemerintahan Daerah dan Pasal 29 ayat (1) huruf $e$ Undang-Undang Nomor 48 Tahun 2009 tentang Kekuasaan Kehakiman terhadap UUD NRI Tahun 1945.

Undang-Undang Nomor 1 Tahun 2015 mengatur mengenai pemilihan kepala daerah secara langsung yang diadakan serentak di seluruh Indonesia, sekaligus didalamnya termasuk juga pengaturan perselisihan hasil pemilihan dilakukan oleh Pengadilan Tinggi dan pengajuan keberatan ke MA. Keberlakuan Undang-Undang Nomor 1 Tahun 2015 ternyata tidak berlangsung lama, tidak perlu menunggu pengundangan, DPR kembali merevisi UU tersebut dengan membentuk Undang-Undang Nomor 8 Tahun 2015. Kini, perkara perselisihan hasil pemilihan diperiksa dan diadili oleh badan peradilan khusus, selama badan tersebut belum terbentuk maka penanganan perkara perselisihan hasil pemilihan dilakukan oleh MK.

Penanganan perselisihan hasil pemilihan kepala daerah yang terbaru ini secara jelas memberikan perbedaan dibandingkan dengan pengaturan mengenai pemilihan kepala daerah sebelumnya baik ketika berdasarkan UndangUndang Nomor 32 Tahun 2004 ataupun berdasarkan Undang-Undang Nomor 12 Tahun 2008. Perbandingan pengaturan diantara UU tersebut, dapat dilihat dalam tabel:

\begin{tabular}{|c|c|c|c|c|}
\hline Dasar Hukum & UU No.32 Tahun 2004 & UU No.12 Tahun 2008, & UU No.1 Tahun 2015 & UU No.8 Tahun 2015 \\
\hline $\begin{array}{l}\text { Lembaga } \\
\text { Berwenang }\end{array}$ & $\begin{array}{l}\text { Pengadilan Tinggi } \\
\text { (perselisihan tk Kab/ } \\
\text { Kota) atau Mahkamah } \\
\text { Agung (perselisihan tk } \\
\text { Prov) }\end{array}$ & $\begin{array}{l}\text { Mahkamah Konstitusi } \\
\text { (sebagai peradilan di } \\
\text { tingkat pertama dan } \\
\text { terakhir) }\end{array}$ & $\begin{array}{l}\text { Pengadilan Tinggi, } \\
\text { Pengajuan keberatan } \\
\text { atas Putusan } \\
\text { Pengadilan Tinggi } \\
\text { kepada MA }\end{array}$ & $\begin{array}{l}\text { Badan peradilan } \\
\text { khusus, sebelum badan } \\
\text { peradilan khusus } \\
\text { terbentuk kewenangan } \\
\text { dilakukan oleh MK. }\end{array}$ \\
\hline $\begin{array}{l}\text { Subyek } \\
\text { Perselisihan }\end{array}$ & $\begin{array}{l}\text { Peserta Pemilihan } \\
\text { dengan KPU Prov/Kab/ } \\
\text { Kota }\end{array}$ & $\begin{array}{l}\text { Peserta Pemilihan } \\
\text { dengan KPU Prov/Kab/ } \\
\text { Kota }\end{array}$ & $\begin{array}{l}\text { Peserta Pemilihan } \\
\text { dengan KPU Prov/Kab/ } \\
\text { Kota }\end{array}$ & $\begin{array}{l}\text { Peserta Pemilihan } \\
\text { dengan KPU Prov/Kab/ } \\
\text { Kota }\end{array}$ \\
\hline $\begin{array}{l}\text { Obyek } \\
\text { Perselisihan }\end{array}$ & $\begin{array}{l}\text { Hasil penghitungan suara } \\
\text { yang mempengaruhi } \\
\text { terpilihnya pasangan } \\
\text { calon }\end{array}$ & $\begin{array}{l}\text { hasil penghitungan } \\
\text { suara yang ditetapkan } \\
\text { oleh Termohon (KPUD) } \\
\text { yang mempengaruhi: } \\
\text { a. penentuan Pasangan } \\
\text { Calon yang dapat } \\
\text { mengikuti putaran } \\
\text { kedua Pilkada; atau } \\
\text { b. terpilihnya Pasangan } \\
\text { Calon sebagai kepala } \\
\text { daerah dan wakil } \\
\text { kepala daerah. }\end{array}$ & $\begin{array}{l}\text { penetapan } \\
\text { perolehan suara } \\
\text { yang signifikan dan } \\
\text { dapat mempengaruhi } \\
\text { penetapan calon } \\
\text { untuk maju ke putaran } \\
\text { berikutnya atau } \\
\text { penetapan calon } \\
\text { terpilih } \\
\text { ket: hanya perolehan } \\
\text { suara dengan selisih } \\
\text { jumlah suara tertentu } \\
\text { yang dapat menjadi } \\
\text { objek perselisihan. }\end{array}$ & $\begin{array}{l}\text { penetapan } \\
\text { perolehan suara } \\
\text { yang signifikan dan } \\
\text { dapat mempengaruhi } \\
\text { penetapan calon } \\
\text { untuk maju ke putaran } \\
\text { berikutnya atau } \\
\text { penetapan calon terpilih } \\
\text { ket: hanya perolehan } \\
\text { suara dengan selisih } \\
\text { jumlah suara tertentu } \\
\text { yang dapat menjadi } \\
\text { objek perselisihan. }\end{array}$ \\
\hline
\end{tabular}




\begin{tabular}{|c|c|c|c|c|}
\hline $\begin{array}{l}\text { Batas Waktu } \\
\text { Permohonan }\end{array}$ & $\begin{array}{l}3 \text { hari setelah penetapan } \\
\text { hasil pemilihan kepala } \\
\text { daerah dan wakil kepala } \\
\text { daerah oleh KPUD }\end{array}$ & $\begin{array}{l}3 \text { hari kerja setelah } \\
\text { penetapan hasil } \\
\text { pemilihan kepala } \\
\text { daerah dan wakil } \\
\text { kepala daerah oleh } \\
\text { KPUD }\end{array}$ & $\begin{array}{l}3 \times 24 \text { jam sejak } \\
\text { diumumkan penetapan } \\
\text { perolehan suara oleh } \\
\text { KPUD }\end{array}$ & $\begin{array}{l}3 \times 24 \text { jam sejak } \\
\text { diumumkan penetapan } \\
\text { perolehan suara oleh } \\
\text { KPUD }\end{array}$ \\
\hline $\begin{array}{l}\text { Batas Waktu } \\
\text { Persidangan }\end{array}$ & $\begin{array}{l}14 \text { hari sejak diterimanya } \\
\text { permohonan }\end{array}$ & $\begin{array}{l}14 \text { hari kerja sejak } \\
\text { permohonan dicatat } \\
\text { dalam Buku Registrasi } \\
\text { Perkara Konstitusi }\end{array}$ & $\begin{array}{l}14 \text { hari sejak diterima } \\
\text { permohonan baik } \\
\text { di Pengadilan tinggi } \\
\text { ataupun di MA }\end{array}$ & $\begin{array}{l}45 \text { hari sejak } \\
\text { diterimanya } \\
\text { permohonan }\end{array}$ \\
\hline $\begin{array}{l}\text { Batas Waktu } \\
\text { Pengajuan } \\
\text { Keberatan }\end{array}$ & $\begin{array}{l}\text {-tidak ada- } \\
\text { (Putusan Pengadilan } \\
\text { Tinggi atau Mahkamah } \\
\text { Agung bersifat final dan } \\
\text { mengikat)* }\end{array}$ & $\begin{array}{l}\text {-tidak ada- } \\
\text { (Putusan MK adalah } \\
\text { peradilan tingkat } \\
\text { pertama dan terakhir } \\
\text { yang putusannya } \\
\text { bersifat final dan } \\
\text { mengikat) }\end{array}$ & $\begin{array}{l}3 \text { hari sejak putusan } \\
\text { Pengadilan Tinggi dapat } \\
\text { mengajukan keberatan } \\
\text { ke Mahkamah Agung }\end{array}$ & $\begin{array}{l}\text {-tidak ada- } \\
\text { (Putusan MK adalah } \\
\text { peradilan tingkat } \\
\text { pertama dan terakhir } \\
\text { yang putusannya } \\
\text { bersifat final dan } \\
\text { mengikat) }\end{array}$ \\
\hline
\end{tabular}

* dalam beberapa kasus, Putusan Pengadilan Tinggi atau Mahkamah Agung dapat dilakukan Peninjauan Kembali (PK)

Perubahan Undang-Undang ini selayaknya harus mengikuti perkembangan hukum ketatanegaraan saat ini serta berusaha untuk memperbaiki penyelesaian perselisihan hasil pemilihan kepala daerah berdasarkan pada evaluasi satu dasawarsa penanganan perselisihan sejak pertama kali ditangani oleh MA pada tahun 2005.

Beberapa perbedaan pengaturan terkait perselisihan hasil pemilihan kepala daerah berdasarkan perbandingan Undang-Undang tersebut, antara lain:

1. Adanya pembatasan objek perkara perselisihan pemilihan yaitu penetapan perolehan suara yang signifikan dan dapat mempengaruhi penetapan calon untuk maju ke putaran berikutnya atau penetapan calon terpilih, makna "signifikan" tersebut kemudian diterjemahkan dengan pengertian hanya perolehan suara dengan selisih jumlah suara tertentu saja yang dapat menjadi objek perselisihan. Rentang selisih suara yang dapat diperselisihkan dari $0.5 \%$ $2 \%$.
2. Lembaga yang berwenang untuk mengadili dan memutus perselisihan hasil pemilihan kepala daerah, berdasarkan UndangUndang Nomor 1 Tahun 2015 ditangani oleh Pengadilan Tinggi dan MA sedangkan berdasarkan Undang-Undang perubahannya ditangani oleh badan peradilan khusus, sebelum terbentuknya badan tersebut perselisihan ditangani oleh MK.

3. Di dalam Undang-Undang Nomor 8 Tahun 2015, batas waktu persidangan perselisihan hasil pemilihan kepala daerah di MK menjadi 45 hari sedangkan di Undang-Undang sebelumnya persidangan paling lama 14 hari.

Dengan adanya pengaturan yang baru ini tentu akan memberikan warna yang baru terhadap karakteristik/model penyelesaian perselisihan hasil pemilihan kepala daerah dibandingkan dengan model penyelesaian ketika di MA berdasar Undang-Undang Nomor 32 Tahun 2004 ataupun model penyelesaian ketika di MK berdasar Undang-Undang Nomor 12 Tahun 2008. 


\section{Optimalisasi Penyelesaian Perselisihan Hasil Pemilihan Kepala Daerah}

Lembaga yang berwenang untuk menangani perselisihan hasil pemilihan masih menimbulkan banyak perdebatan, dengan saling berpindahnya kewenangan lembaga yang berhak menangani perselisihan hasil pemilihan menjadi pertanyaan besar kemanakah arah kebijakan penanganan sengketa hasil pemilihan ini?, apakah di MK atau MA ataukah badan peradilan khusus?

Pasca putusan MK yang berisi bahwa MK tidak berwenang menangani perselisihan hasil pemilihan kepala daerah maka lembaga yang memungkinkan untuk menangani perselisihan hasil pemilihan adalah Pengadilan Tinggi atau MA seperti tercantum dalam UndangUndang Nomor 1 Tahun 2015 atau dibentuk badan peradilan khusus yang menangani penyelesaian perselisihan pemilihan kepala daerah sebagaimana yang tercantum dalam UU perubahannya.

Menurut hemat penulis, optimalisasi Pengadilan Tinggi atau MA untuk menangani perselisihan lebih tepat dibandingkan pembentukan badan peradilan khusus pemilihan kepala daerah. hal yang perlu dipertimbangkan antara lain:

a. pemilihan kepala daerah selanjutnya akan dilakukan secara serentak lima tahun sekali. Tidak efisien untuk membentuk suatu badan peradilan baru, dimana badan tersebut hanya bekerja lima tahun sekali. Hal ini berbeda dengan pengadilan khusus seperti pengadilan pajak atau pengadilan hubungan industrial yang memiliki perkara rutin yang harus ditangani.

Pelaksanaan pemilihan secara serentak juga menjadi alasan bahwa MA tidak perlu khawatir sengketa pemilihan kepala daerah akan semakin menambah banyak tumpukan perkara di MA. Perkara perselisihan hasil pemilihan hanya akan ditangani dalam masa tertentu ( 5 tahunan), objek perkara tertentu (rentang selisih suara 0,5\%-2\%) dan dengan batas waktu persidangan yang juga sudah ditentukan ( dalam Undang-Undang Nomor 1 Tahun 2015 ditentukan paling lama 14 hari), oleh karena itu, perkara perselisihan pemilihan dirasa tidak akan signifikan menyita waktu persidangan.

b. MA dan Pengadilan Tinggi telah memiliki SDM dan infrastuktur pengadilan yang siap untuk digunakan. SDM hakim dan infrastuktur pengadilan tersebut masih dapat digunakan untuk menangani sengketa lain apabila masa penanganan perselisihan hasil pemilihan telah selesai dilakukan, hal ini lebih efisien dibanding dengan adanya pembentukan badan peradilan baru yang tentu perlu pula ada penyiapan infrastruktur dan SDM baru untuk badan peradilan tersebut. Selama ini penanganan sengketa administrasi antara calon dan KPU ditangani oleh Pengadilan TUN, sedangkan perkara pidana ditangani di pengadilan umum, dengan demikian sesungguhnya hakim di lingkungan peradilan di MA telah familiar dengan jenis perselisihan terkait pemilihan kepala daerah.

c. perselisihan pemilihan kepala daerah banyak jenisnya dapat berupa pelanggaran etik, administrasi, tindak pidana ataupun tata usaha negara, terlalu kompleks untuk menempatkan berbagai jenis perselisihan tersebut ke dalam satu badan peradilan tersendiri. Hal ini juga mempertimbangkan konsistensi prinsip satu atap kekuasaan kehakiman dibawah MA. 
Penanganan perselisihan hasil pemilihan kepala daerah sesungguhnya layak untuk dilakukan oleh MA namun tentu dengan berbagai optimalisasi perbaikan sebagaimana refleksi satu dasawarsa penanganan perselisihan hasil pemilihan antara lain pendekatan mekanisme penanganan perkara, penyiapan materi SDM hakim serta perbaikan lembaga-lembaga lain yang terkait dengan penanganan perselisihan pemilihan kepala daerah.

\section{a. Optimalisasi Perbaikan Mekanisme Penanganan Perselisihan Hasil Pemilihan}

Selama satu dasawarsa penanganan perselisihan hasil pemilihan kepala daerah baik ditangani oleh MA ataupun MK, masing-masing memiliki karakteristik tersendiri, penanganan di MA lebih mengedepankan pada prinsip keadilan prosedural (procedural justice) sedangkan di MK lebih mengutamakan keadilan substantive (substantive justice). Karakteristik dari peradilan procedural dan peradilan substantive memiliki perbedaan $^{14}$

Pendekatan yang dilakukan oleh MA akan lebih terlihat kepastian hukumnya mengingat penanganan yang dilakukan sesuai dengan peraturan perundang-undangan dan dapat terhindar dari pergulatan substansi yang bisa menarik keluar konteks penanganan perselisihan dari yang seharusnya. Namun begitu, melalui mekanisme ini peserta pemilihan tidak bisa berharap banyak untuk dapat menggali keadilan selama penyelenggaraan pemilu, karena penanganan di MA sesuai kewenangannya terbatas pada rekapitulasi hasil suara.
Pendekatan yang dilakukan oleh MK dengan hukum progresifnya akan lebih memuaskan rasa keadilan dari pemohon karena prinsip bahwa tidak ada satupun pasangan calon yang boleh diuntungkanataupun dirugikan dalamperolehan hasil suara akibat terjadinya pelanggaran selama tahap penyelenggaraan pemilihan dapat benarbenar diterapkan, walaupun kemudian ada pula yang merespon negative pendekatan ini karena MK dinilai telah menyimpang dari undangundang serta putusan yang dikeluarkan tidak jarang pula meninggalkan perdebatan substansi di luar pengadilan.

Berdasarkan penilaian satu dasawarsa penanganan penyelesaian perselisihan hasil pemilu, penulis menilai positif pendekatan MK sewaktu menangani permasalahan Pilkada. Walaupun ada pandangan bahwa MK telah keluar dari koridor hukum yang seharusnya, namun demikian terobosan hukum tersebut harus dilakukan agar MK dalam kerangka hukum progresifnya tidak hanya mengadili dari sisi aspek rigiditas hukum saja tetapi lebih dari itu melampaui hukum dalam rangka mencari keadilan yang sebenar-benarnya.

Penulis menilai bahwa pendekatan yang selama ini telah dilakukan oleh MK dengan mengutamakan keadilan substantive (substantive justice) perlu untuk dilakukan kembali dalam menangani perselisihan hasil pemilihan di masa mendatang. Perselisihan hasil pemilihan kepala daerah pada dasarnya tidak hanya sebatas perselisihan perdata dari pihak yang terlibat, namun lebih dari itu menyangkut pula kepentingan masyarakat luas dan juga dalam rangka menjaga nilai-nilai demokrasi yang jujur dan adil.

4 Faisal, Menerobos Positivisme Hukum, (Jakarta: Gramata Publishing, 2012), hal 69. 
Gustav Radbruch menuturkan bahwa hukum adalah pengemban nilai keadilan, keadilan memiliki sifat normatif sekaligus konstitutif bagi hukum. Bersifat normative karena kepada keadilanlah, hukum positif berpangkal. Bersifat konstitutif karena keadilan harus menjadi unsur mutlak bagi hukum, tanpa keadilan, sebuah aturan tidak pantas menjadi hukum ${ }^{15}$. Hal ini memperhatikan pula asas prioritas yang dikemukakan oleh Gustav Radbruch bahwa untuk menerapkan hukum secara tepat dan adil untuk memenuhi tujuan hukum maka yang diutamakan adalah keadilan, kemudian kemanfaatan setelah itu kepastian hukum ${ }^{16}$.

Berdasarkan pemaparan tersebut, layak dipertimbangkan bahwa pendekatan yang dilakukan lembaga penanganan perselisihan hasil pemilihan masa depan adalah pendekatan substantive. Optimalisasi penanganan sengketa pemilihan oleh KPU, Bawaslu ataupun lembaga lainnya di tahap awal tidak menjadikan Pengadilan perselisihan hasil pemilihan hanya sebagai pengadilan penghitungan, dalam hal lembaga hukum di tahap sebelumnya tidak bekerja sebagaimana mestinya, sensitivitas keadilan tersebut harus dijaga oleh MA.

Undang-Undang Nomor 1 Tahun 2015 memberikan penguatan berupa pengaturan dibentuknya Majelis Khusus di Pengadilan Negeri dan Pengadilan Tinggi untuk penanganan tindak pidana, Majelis Khusus di Pengadilan TUN untuk perselisihan tata usaha negara serta hakim yang menangani perselisihan hasil pemilihan. Pengaturan ini masih dipertahankan dalam UU perubahannya.
Langkah ini harus diperkuat kembali dengan memastikan bahwa hakim-hakim yang ada di dalam Majelis Khusus tersebut adalah hakim yang memiliki integritas berdasarkan rekam jejaknya, mengingat perkara pemilu sangat sarat kepentingan politik dan ekonomi. Selain itu, hakim tersebut harus pula memiliki pengetahuan yang luas seputar hukum pemilihan kepala daerah dan yang terpenting adalah memiliki karakter untuk mampu menggali keadilan sedalam-dalamnya untuk menjaga nilai-nilai demokrasi yang terkandung dalam penyelenggaraan pemilihan kepala daerah.

Pengadilan yang merdeka, netral, kompeten dan berwibawa yang mampu menegakkan wibawa hukum, pengayoman hukum, kepastian hukum dan keadilan merupakan condition sine qua non negara yang berdasarkan hukum. ${ }^{17}$ Pengadilan sebagai rumah keadilan pelaksanaannya diwakili oleh hakim, oleh karena itu, kepercayaan masyarakat terhadap hukum dan institusi peradilan sangat ditentukan oleh kredibilitas dan profesionalitas hakim dalam menjalankan tugasnya menyelesaikan perselisihan serta menegakkan keadilan ${ }^{18}$. Berdasarkan hal ini pula selain hakim karier dapat dipertimbangkan merekruit ahli lain sebagai hakim non karier.

Tantangan selanjutnya adalah membuat hukum acara yang memungkinkan keadilan dapat diperjuangkan sekaligus menjamin kepastian hukum. Dibutuhkan pelaksanaan persidangan yang cepat,terbuka dan putusan yang final dan mengikat dalam penyelesaian

\footnotetext{
15 Bernard L Tanya dkk, Teori Hukum: Strategi Tertib Manusia Lintas Ruang dan Generasi, (Yogyakarta, Genta Publising, 2013), hal 117

16 Satjipto rahardo, ilmu hukum, (Bandung, Citra Aditya Bakti, 2000), hal 20.

17 Ali Taher Parasong, Mencegah Runtuhnya Negara Hukum,(Jakarta:Grafindo,2014), hal 223

18 Didik Sukriono, Hukum, Konstitusi dan Konsep Otonomi, (Malang: Setara Press, 2013), hal 104
} 
perselisihan hasil pemilihan kepala daerah sehingga tidak menyebabkan kekosongan pemerintahan di daerah.

Demokrasi yang diharapkan adalah demokrasi electoral sekaligus demokrasi substantive, jika realisasi demokrasi electoral diukur hanya sebatas pemilu yang bebas, kompetitif dan demokratis, maka realisasi demokrasi substantive mensyaratkan lebih dari sekedar penyelanggaraan pemilu. Demokrasi substantive mencakup aspek yang lebih luas meliputi kebebasan sipil dan politik, jaminan HAM hingga terwujudnya good governance ${ }^{19}$.

\section{b. Optimalisasi Perbaikan Lembaga Penanganan Perselisihan Pemilihan.}

Berdasarkan kasus-kasus perselisihan hasil pemilihan kepala daerah yang masuk ke MA ataupun MK selama satu dasawarsa terakhir, para calon kepala daerah banyak yang memasukkan pelanggaran-pelanggaran administrasi, tindak pidana pemilu dan perselisihan dalam tahapan pemilihan sebagai dasar gugatan untuk di MA ataupun MK, padahal kasus - kasus tersebut bukan kewenangan MA atau MK untuk memutusnya, terkait dengan hal ini, menurut Hakim MK, Hamdan Zoelva, ada tiga kemungkinan kenapa hal tersebut dapat terjadi, yaitu ${ }^{20}$ :

1. peserta pemilihan masih tidak puas dengan penyelenggaraan Pemilihan baik dalam prosesnya maupun dalam hasil akhirnya.

2. Ketidakpercayaan dan pengabaian peserta pemilihan terhadap instansi lembaga hukum atau pengawas pemilihan.

3. ketidakpahaman dasar gugatan yang diajukan para peserta pemilihan.

Saat ini telah ada Lembaga-lembaga yang terkait dengan penyelesaian perselisihan hukum semacam itu seperti dalam tabel berikut:
Model pelanggaran/perselisihan

Pelanggaran Kode Etik Pemilu

Pelanggaran Administrasi

Perselisihan pemilihan

Tindak Pidana Pemilihan

\section{Lembaga yang berwenang}

Diperiksa dan diputus oleh Dewan Kehormatan Penyelenggara Pemilu (DKPP)

Diperiksa oleh Bawaslu untuk kemudian penanganannya diselesaikan oleh KPU Prov/Kab/Kota

Diperiksa dan diputus oleh Bawaslu Prov dan Panwaslu Kab/Kota

Disidik oleh Kepolisian kemudian penyelesaiannya diteruskan kepada

Pengadilan Negeri untuk diperiksa, diadili, dan diputus perkaranya.

Putusan Pengadilan Negeri dapat diajukan banding ke Pengadilan Tinggi.

Perselisihan Tata Usaha Negara Penanganan melalui upaya administrative di Bawaslu Prov dan/atau (TUN) Panwas.

Dalam hal perselisihan TUN belum putus, Pengajuan gugatan atas perselisihan TUN dilakukan ke Pengadilan Tinggi TUN.

Perselisihan Hasil Pemilihan Mahkamah Konstitusi 
Pengalaman penanganan perselisihan hasil pemilihan kepala daerah, hampir selalu tidak terlepas dari pelanggaran-pelanggaran yang terjadi di hulunya yaitu pada tahap penyelenggaraan pemilihan, oleh karena itu optimalisasi lembaga pemutus perselisihan hasil pemilihan kepala daerah harus disertai pula dengan perbaikan kinerja lembaga - lembaga lainnya yang memutus perselisihan pada tahap awal proses penyelenggaran pemilihan. Apabila peserta pemilu sudah mendapatkan keadilan dari lembaga - lembaga hukum penyelenggara pemilu maka tentu semuanya tidak akan menggantungkan nasibnya pada lembaga yudikatif seperti MA atau MK. Lembaga hukum pemilihan kepala daerah yang dimaksud antara lain ${ }^{21}$ :

1. Komisi Pemilihan Umum Daerah selaku penyelenggara Pilkada yang mempunyai wewenang memberikan sanksi terhadap para pelaku pelanggaran administrasi pemilu,

2. Bawaslu Prov atau Panwas Kab/Kota selaku pengawas yang diberi wewenang untuk memastikan ada-tidaknya pelanggaran pemilu dan menyelesaikaan perselisihan non-hasil Pilkada,

3. jajaran kepolisian dan kejaksaan,

4. lembaga peradilan yang berwenang menyidangkan dan menjatuhkan vonis terhadap pelaku penyelenggaran Pilkada.

Terkait dengan penanganan tindak pidana, Pasal 150 Perpu No.1 Tahun 2014 menyatakan bahwa "putusan pengadilan yang menurut Undang-Undang dapat mempengaruhi perolehan suara peserta pemilihan harus sudah selesai paling lama 5 (lima) hari sebelum KPU Prov/Kab/Kota menetapkan hasil pemilihan", selanjutnya "KPU Prov/Kab/Kota wajib menindaklanjuti putusan pengadilan terkait tindak pidana tersebut", frase ini seharusnya dimanfaatkan semaksimal mungkin bagi para peserta pemilihan, sehingga kasus-kasus tindak pidana tidak perlu lagi diperkarakan di pengadilan perselisihan hasil pemilihan kepala daerah.

\section{Penutup}

Undang-Undang Nomor 1 Tahun 2015 telah mengamanahkan MA sebagai lembaga yang berwenang mengadili dan memutus perselisihan hasil pemilihan, namun tak berlangsung lama, Undang-Undang tersebut direvisi dengan memberikan kewenangan mengadili dan memutus perselisihan hasil pemilihan kepada badan peradilan khusus, sebelum terbentuknya badan peradilan tersebut, kewenangan dilakukan oleh MK. Saling limpah-melimpahkan kewenangan ini sesungguhnya telah memberikan keraguan tentang kemanakah arah penanganan perselisihan hasil pemilihan kepala daerah di masa mendatang.

Pembelajaran hukum selama satu dasawarsa terakhir penanganan perselisihan hasil pemilihan harus didalami untuk memperoleh model penyelesaian perselisihan hasil pemilihan kepala daerah yang lebih baik lagi. Dalam hal MK tidak berwenang menangani perselisihan maka MA atau Pengadilan Tinggi sesungguhnya masih layak untuk dijadikan lembaga yang berwenang menangani perselisihan tersebut dibanding badan peradilan khusus, walaupun tentu dengan berbagai perbaikan berdasarkan refleksi satu dasawarsa penanganan perselisihan.

Pengalaman pendekatan hukum progresif yang telah dilakukan oleh MK selama beberapa tahun terakhir dinilai lebih menjamin

21 Hamdan Zoelva, ibid. hal 392. 
tercapainya keadilan yang diharapkan oleh para pihak, berdasarkan hal itu, pendekatan penanganan perselisihan hasil pemilihan perlu untuk dikawal. Perlu kebijakan dari MA yang mengarah pada rekrutmen/penempatan hakim-hakim yang berintegritas dan mumpuni dalam menangani perselisihan pemilihan kepala daerah, serta hakim yang mengedepankan keadilan substantive dalam penyelesaian perselisihan hasil. Terkait penunjukan hakim harus dibuka juga kemungkinan untuk hakim non karier baik berasal dari praktisi atau akademisi untuk menempati posisi tersebut.

Pengalaman satu dasawarsa terakhir menunjukan bahwa persidangan perselisihan hasil pemilihan tidak semata-mata menampilkan sengketa hasil saja, namun lebih dari itu banyak pula pelanggaran tindak pidana yang dikeluhkan, oleh karena itu perbaikan tidak cukup hanya pada tahap penanganan perselisihan hasil pemilihan, namun perlu pula ada optimalisasi di tahap-tahap sebelum perselisihan hasil diperkarakan. Optimalisasi penegakan hukum yang dilakukan oleh KPU, Bawaslu/Panwaslu, DKPP ataupun penegak hukum lainnya yang menangani sengketa di tahap awal perlu terus ditingkatkan sehingga tidak menjadikan beban berat pada saat penanganan perselisihan hasil pemilihan.

\section{DAFTAR PUSTAKA}

\section{Buku:}

Akbar, Patrialis, Lembaga-Lembaga Negara Menurut UUD NRI Tahun 1945, (Jakarta: Sinar Grafika, 2013)

Faisal, Menerobos Positivisme Hukum, (Jakarta: Gramata Publishing, 2012)

Gaffar, Janedjri M, Hukum Pemilu dalam Yurisprudensi Mahkamah Konstitusi, (Jakarta: Konstitusi Pres, 2013)

Lotulung,Paulus Effendi, Aspek Yuridis masalah Sengketa Pilkada, (Jakarta:LPPHAN, 2005)
Manan, Munafrizal, Partai Politik dan Demokrasi Indonesia menyongsong Pemilihan Umum 2014, (Jurnal Legislasi Indonesia, vol. 9 No. 4, Desember 2012)

Parasong, Ali Taher, Mencegah Runtuhnya Negara Hukum,(Jakarta:Grafindo,2014)

Rahardjo, Satjipto, Ilmu Hukum, (Bandung: Citra Aditya Bakti, 2000)

Soekanto, Soejono, Pengantar Penelitian Hukum, (Jakarta: UI Press, 2010)

Sukriono, Didik, Hukum, Konstitusi dan Konsep Otonomi, (Malang: Setara Press, 2013)

Tanya, Bernard L, dkk, Teori Hukum: Strategi Tertib Manusia Lintas Ruang dan Generasi, (Yogyakarta: Genta Publising, 2013)

Widjojanto, Bambang, Kajian Putusan MK tentang Pemilu \& Pilkada, (Jakarta: Kemitraan, 2009)

Zoelva, Hamdan, Problematika Penyelesaian Sengketa Hasil Pilkada oleh Mahkamah Konstitusi, (Jurnal Konstitusi volume 10, nomor 3, September 2013)

\section{Peraturan Perundang-undangan}

Undang-Undang No. 32 Tahun 2004 tentang Pemerintahan Daerah.

Undang-Undang No. 22 Tahun 2007 tentang Penyelenggaraan Pemilihan Umum.

Undang-Undang No. 12 Tahun 2008 tentang Perubahan atas UU No. 32 Tahun 2004 tentang Pemerintahan Daerah.

Undang-Undang No.1 Tahun 2015 tentang Penetapan Perppu No.1 Tahun 2014 tentang Pemilihan Gubernur, Bupati dan Walikota menjadi UU.

Perma No. 2 Tahun 2005 tentang Tata Cara Pengajuan Upaya Hukum Keberatan Penetapan Hasil Pilkada dan Pilwakada KPUD Provinsi dan KPUD Kab/Kota.

PMK No. 15 Tahun 2008 tentang Pedoman Beracara Dalam Perselisihan Hasil Pemilihan Umum Kepala Daerah

\section{Putusan Pengadilan}

Putusan Pengadilan Tinggi Jawa Barat No.01/ PILKADA/2005/PT.Bdg.

Putusan Mahkamah Agung Nomor 01 PK/ PILKADA/2005.

Putusan Mahkamah Konstitusi No. 41/PHPU.D$\mathrm{VI} / 2008$. 


\title{
INISIASI PENGADILAN KHUSUS PEMILIHAN KEPALA DAERAH DALAM MENGHADAPI KESERENTAKAN PEMILIHAN GUBERNUR, BUPATI, DAN WALIKOTA DI INDONESIA ${ }^{1 *}$
}

\author{
(Initiation of Special Court on the Local Election for Regional Leaders \\ to Face the Simultaneously Election of Governor, Regent, and Mayor in Indonesia)
}

\author{
Dian Agung Wicaksono \\ Bagian Hukum Tata Negara Fakultas Hukum Universitas Gadjah Mada \\ Jl. Sosio Yustisia No. 1 Bulaksumur, Sleman, D.I. Yogyakarta \\ Email: dianagung@ugm.ac.id \\ Ola Anisa Ayutama \\ Program Studi Ilmu Hukum Fakultas Hukum Universitas Gadjah Mada \\ JI. Sosio Yustisia No. 1 Bulaksumur, Sleman, D.I. Yogyakarta \\ Email: ola.anisa@ymail.com
}

Naskah diterima: 5 Februari 2015; revisi: 24 April 2015; disetujui: 30 April 2015

\begin{abstract}
Abstrak
Pasca pengesahan Peraturan Pemerintah Pengganti Undang-Undang (selanjutnya disingkat Perppu) Nomor 1 Tahun 2014 tentang Pemilihan Gubernur, Bupati, dan Walikota (selanjutnya disebut Pemilihan Kepala Daerah, yang disingkat Pilkada) terdapat desain baru yang diusung terkait mekanisme Pilkada. Dalam Perppu tersebut, Pilkada diselenggarakan secara serentak pada level nasional. Desain keserentakan ini tentu membutuhkan regulasi pendukung, salah satunya melalui pembentukan pengadilan khusus Pilkada. Permasalahan yang kemudian muncul dalam penelitian ini adalah terkait bagaimana urgensi dibentuknya pengadilan khusus Pilkada, bagaimana perbandingan pengadilan khusus Pilkada di berbagai negara dan bagaimana relevansi perbandingan tersebut dapat diterapkan di Indonesia. Penelitian ini dilakukan dengan metode yuridis normatif. Kesimpulan dari penelitian ini adalah terdapat urgensi untuk dibentuk pengadilan khusus Pilkada dikarenakan upaya hukum dalam proses Pilkada selama ini seringkali tidak dapat memenuhi rasa keadilan masyarakat, misalnya putusan pengadilan yang baru diputus pasca tahapan Pilkada telah dilaksanakan dan berlapislapisnya upaya hukum Pilkada sehingga kontraproduktif dengan tahapan Pilkada yang dibatasi jangka waktu. Terlebih upaya hukum tersebut terpisah dalam beberapa lingkungan peradilan. Di berbagai negara pun telah dibentuk pengadilan khusus Pilkada dengan berbagai desain kelembagaan dan hukum acaranya. Untuk Indonesia, Pengadilan Pilkada didesain sebagai pengadilan khusus yang bersifat ad hoc, berkedudukan di Provinsi dan Kabupaten atau Kota serta berwenang memutus sengketa tentang Pilkada.
\end{abstract}

Kata Kunci: pengadilan khusus, pemilihan kepala daerah, pemilihan serentak.

\begin{abstract}
Post-approval of Government Regulation in Lieu of Law No. 1 of 2014 concerning the Election of Governor, Regent, and Mayor (hereinafter called local election), there is a new design in election mechanisms of regional head. The Law a quo stated that the elections be held simultaneously at the national level. This design would require regulatory support, such as the establishment of special courts to solve any disputes that arise from the election. The problems emerge in this study is how the urgency of a special court, how it compares to special court on election matters in various countries and how the relevance of the comparison can be applied in Indonesia. This was conducted using a legal-normative research. The research conclude that it is urgent to set up special courts on local elections due to legal remedy in the local election process that has been often unable to meet the demands for justice, for example, the court's decision are settled after the elections conducted and thick-layers on legal remedies so it is counterproductive to the elections that have limited period of time. These legal remedies are even separated in several judicatures. Various countries have also established a special court on local elections with a variety of institutional design and procedural law. For Indonesia, the special court is an ad hoc court, based on provincial and district or city and authorized to settle disputes concerning the local elections.
\end{abstract}

Keywords: special court, local election for regional leaders, simultaneous election

1 Versi sebelumnya dari tulisan ini disajikan pada Seminar Pengkajian Hukum Nasional (SPHN 2014) "Prospek Pembaruan Hukum Pemerintahan Joko Widodo dan Muhammad Jusuf Kalla Periode Tahun 2014-2019”, Hotel Bidakara, Jakarta, 2-3 Desember 2014. 


\section{A. Pendahuluan}

Indonesia termasuk salah satu negara yang meneguhkan diri sebagai negara demokratis. Konsep demokrasi yang dipilih oleh Indonesia adalah demokrasi konstitusional sebagaimana bunyi rumusan Pasal 1 ayat (2) Undang-Undang Dasar Negara Republik Indonesia Tahun 1945 (UUD NRI Tahun 1945) yang menegaskan bahwa, "Kedaulatan berada di tangan rakyat dan dilaksanakan menurut Undang-Undang Dasar 1945"2. Salah satu bentuk perwujudan instrumen demokrasi tersebut adalah melalui pemilihan kepala daerah (Pilkada). Instrumentasi demokrasi di daerah berupa Pilkada tidak dapat dilepaskan dari konsep pelimpahan pelaksanaan urusan pemerintahan kepada daerah (decentralisation), namun pula devolusi kekuasaan (political decentralization). ${ }^{3}$ Pemilihan ini merupakan momentum bagi masyarakat daerah untuk menyalurkan otonominya dalam menentukan siapa yang akan memimpin pembangunan di daerahnya, sehingga dengan adanya hal tersebut pembangunan kesejahteraan daerah akan lebih berbasis pada kepentingan masyarakat. Mengingat pentingnya peran Pilkada, maka dalam Pasal 18 ayat (4) UUD NRI Tahun 1945 telah ditegaskan bahwa "Gubernur, Bupati, dan Walikota masing-masing sebagai kepala pemerintah daerah provinsi, kabupaten, dan kota dipilih secara demokratis." ${ }^{4}$ Selanjutnya, Pasal 18 ayat (7) UUD NRI Tahun 1945 menyatakan bahwa "Susunan dan tata cara penyelenggaraan pemerintahan daerah diatur dalam undangundang" ${ }^{5}$, yang maknanya pengaturan Pilkada sebagai salah satu bentuk penyelenggaraan pemerintahan daerah diserahkan pada tataran Undang-Undang.

Di Indonesia, pengaturan mengenai Pilkada selama ini masuk sebagai substansi UndangUndang Pemerintahan Daerah, mulai dari Undang-Undang Nomor 22 Tahun 1999 tentang Pemerintahan Daerah, yang selanjutnya dicabut dengan Undang-Undang Nomor 32 Tahun 2004 dan perubahannya, yaitu Undang-Undang Nomor 12 Tahun 2008. Namun demikian, Dewan Perwakilan Rakyat (DPR) dan Pemerintah telah membuat kesepakatan bersama untuk tidak lagi memasukkan Pilkada sebagai substansi Undang-Undang Pemerintahan Daerah, yang tindak lanjutnya dengan memecah UndangUndang Pemerintahan Daerah ke dalam 3 (tiga) Undang-Undang, yaitu Undang-Undang tentang Pemerintahan Daerah, Undang-Undang tentang Desa dan Undang-Undang tentang Pilkada. Diharapkan melalui pemecahan Undang-Undang Pemerintahan Daerah ke dalam tiga Undang-Undang tersebut akan memberikan ruang pengaturan yang lebih rinci dan komprehensif dari masing-masing isu tersebut sehingga memberikan kontribusi pada kelancaran jalannya roda pemerintahan daerah secara keseluruhan. ${ }^{6}$

Implementasi dari kesepakatan tersebut, terbitlah Undang-Undang Nomor 22 Tahun 2014 tentang Pemilihan Gubernur, Bupati, dan

Pasal 1 ayat (2) Undang-Undang Dasar Negara Republik Indonesia Tahun 1945.

William Tordoff, "Decentralisation: Comparative Experience in Commonwealth Africa", The Journal of Modern African Studies 32:4 (Dec., 1994): 573.

Pasal 18 ayat (4) Undang-Undang Dasar Negara Republik Indonesia Tahun 1945.

Pasal 18 ayat (7) Undang-Undang Dasar Negara Republik Indonesia Tahun 1945.

6 Gamawan Fauzi, "Keterangan Pemerintah Atas Rancangan Undang-Undang tentang Pemerintahan Daerah" (Rapat Kerja Pansus Rancangan Undang-Undang tentang Pemerintahan Daerah, Jakarta, 3 April 2012). 
Walikota yang kemudian dikarenakan polemik mekanisme pemilihan, akhirnya dianulir oleh Presiden dengan penerbitan Peraturan Pemerintah Pengganti Undang-Undang Nomor 1 Tahun 2014 tentang Pemilihan Gubernur, Bupati, dan Walikota (Perppu Pilkada). Permasalahan mendasar yang menjadi diskursus pengaturan adalah terkait mekanisme Pilkada apakah secara langsung atau tidak langsung. Pun pada awalnya menuai perdebatan terkait hal tersebut pada DPR periode tahun 2004-2009, namun pada akhirnya pada tanggal 20 Januari 2015, DPR periode 2009-2014 mengesahkan Perppu Pilkada menjadi Undang-Undang Nomor 1 Tahun 2015 tentang Penetapan Peraturan Pemerintah Pengganti Undang-Undang Nomor 1 Tahun 2014 tentang Pemilihan Gubernur, Bupati, dan Walikota Menjadi Undang-Undang (UU Pilkada), dengan catatan mengusulkan agar dilakukan revisi setelah resmi disahkan menjadi UU. ${ }^{7}$

Menurut UU Pilkada, Pilkada serentak secara nasional akan dilaksanakan pada tahun $2020,{ }^{8}$ namun kemudian dalam perubahan UU Pilkada yang sudah disahkan dalam Rapat Paripurna DPR disepakati bahwa Pilkada serentak dalam beberapa tahap yang dimulai Desember 2015, serta pelaksanaan pemilihan serentak nasional pada tahun 2027. ${ }^{9}$ Berikut adalah beberapa poin materi perubahan UU Pilkada yang disahkan pada tanggal 17 Februari 2015, yaitu: ${ }^{10}$

1. Penguatan pendelegasian tugas kepada KPU dan Bawaslu sebagai penyelenggara pemilihan disertai adanya penguatan bahwa kedua lembaga tersebut secara atributif diberikan tugas oleh UU ini ${ }^{11}$, untuk menegaskan bahwa pemilihan Gubernur, Bupati, dan Walikota adalah rezim pemerintahan daerah sebagaimana Pasal 18 ayat (4) UUD NRI Tahun 1945.

2. Syarat pendidikan Gubernur, Bupati, dan Walikota tetap seperti dalam Perppu Nomor 1 Tahun 2014, yaitu berpendidikan paling rendah SLTA atau sederajat. ${ }^{12}$

3. Syarat usia Gubernur tetap seperti dalam Perppu Nomor 1 Tahun 2014, yaitu berusia

A. Haryo Damardono dan Anita Yossihara, "Paripurna DPR Sahkan Pilkada Langsung" (Kompas, 20 Januari 2015).

8 Pasal 201 ayat (5) Undang-Undang Nomor 1 Tahun 2015 tentang Penetapan Peraturan Pemerintah Pengganti Undang-Undang Nomor 1 Tahun 2014 tentang Pemilihan Gubernur, Bupati, dan Walikota Menjadi UndangUndang (Lembaran Negara Republik Indonesia Tahun 2015 Nomor 23, Tambahan Lembaran Negara Republik Indonesia Nomor 5656).

9 Dewan Perwakilan Rakyat Republik Indonesia, "Paripurna DPR Setujui Revisi UU Pilkada dan RUU Pemda Menjadi UU", http://dpr.go.id/berita/detail/id/9734, (diakses 11 Maret 2015).

10 Diolah oleh Penulis dengan membandingkan antara Undang-Undang Nomor 8 Tahun 2015 tentang Perubahan Atas Undang-Undang Nomor 1 Tahun 2015 tentang Penetapan Peraturan Pemerintah Pengganti Undang-Undang Nomor 1 Tahun 2014 tentang Pemilihan Gubernur, Bupati, dan Walikota Menjadi Undang-Undang (Lembaran Negara Republik Indonesia Tahun 2015 Nomor 57, Tambahan Lembaran Negara Republik Indonesia Nomor 5678) dengan Undang-Undang Nomor 1 Tahun 2015 tentang Penetapan Peraturan Pemerintah Pengganti Undang-Undang Nomor 1 Tahun 2014 tentang Pemilihan Gubernur, Bupati, dan Walikota Menjadi UndangUndang (Lembaran Negara Republik Indonesia Tahun 2015 Nomor 23, Tambahan Lembaran Negara Republik Indonesia Nomor 5656).

11 Penjelasan Undang-Undang Nomor 8 Tahun 2015 tentang Perubahan Atas Undang-Undang Nomor 1 Tahun 2015 tentang Penetapan Peraturan Pemerintah Pengganti Undang-Undang Nomor 1 Tahun 2014 tentang Pemilihan Gubernur, Bupati, dan Walikota Menjadi Undang-Undang (Lembaran Negara Republik Indonesia Tahun 2015 Nomor 57, Tambahan Lembaran Negara Republik Indonesia Nomor 5678).

12 Pasal 7 huruf c Undang-Undang Nomor 8 Tahun 2015 tentang Perubahan Atas Undang-Undang Nomor 1 Tahun 2015 tentang Penetapan Peraturan Pemerintah Pengganti Undang-Undang Nomor 1 Tahun 2014 tentang Pemilihan Gubernur, Bupati, dan Walikota Menjadi Undang-Undang (Lembaran Negara Republik Indonesia Tahun 2015 Nomor 57, Tambahan Lembaran Negara Republik Indonesia Nomor 5678). 
paling rendah 30 tahun dan Bupati/Walikota berusia paling rendah 25 tahun. ${ }^{13}$

4. Tahapan Uji Publik dihapus. ${ }^{14}$ Dengan alasan bahwa proses tersebut menjadi domain atau kewajiban dari partai politik dan termasuk perseorangan yang harus melakukan proses sosialisasi calon. ${ }^{15}$

5. Syarat dukungan penduduk untuk Calon Perseorangan dinaikkan 3,5\%, sehingga nantinya threshold perseorangan antara 6,5\%-10\%. Tergantung daerah dan jumlah penduduknya. ${ }^{16}$

6. Pembiayaan Pilkada dari APBD didukung APBN. ${ }^{17}$

7. Ambang batas kemenangan $0 \%$, artinya satu putaran. ${ }^{18}$ Alasannya untuk efisiensi baik waktu maupun anggaran. Selain itu, dengan syarat dukungan baik dari partai politik atau gabungan partai politik dan calon perseorangan yang sudah dinaikkan maka sesungguhnya para calon sudah memiliki dasar legitimasi yang cukup. Proses pemilihan menjadi lebih sederhana.

8. Tentang sengketa hasil Pilkada disepakati bahwa sebelum terbentuknya lembaga peradilan khusus yang menangani, maka proses penyelesaiannya dilakukan oleh Mahkamah Konstitusi. ${ }^{19}$

9. Jadwal Pilkada dilaksanakan dalam beberapa gelombang sebagai berikut:
a. Gelombang pertama dilaksanakan Desember 2015 (untuk akhir masa jabatan 2015 dan semester pertama tahun 2016). ${ }^{20}$

13 Pasal 7 huruf e Undang-Undang Nomor 8 Tahun 2015 tentang Perubahan Atas Undang-Undang Nomor 1 Tahun 2015 tentang Penetapan Peraturan Pemerintah Pengganti Undang-Undang Nomor 1 Tahun 2014 tentang Pemilihan Gubernur, Bupati, dan Walikota Menjadi Undang-Undang (Lembaran Negara Republik Indonesia Tahun 2015 Nomor 57, Tambahan Lembaran Negara Republik Indonesia Nomor 5678).

14 Pasal 5 ayat (3) Undang-Undang Nomor 8 Tahun 2015 tentang Perubahan Atas Undang-Undang Nomor 1 Tahun 2015 tentang Penetapan Peraturan Pemerintah Pengganti Undang-Undang Nomor 1 Tahun 2014 tentang Pemilihan Gubernur, Bupati, dan Walikota Menjadi Undang-Undang (Lembaran Negara Republik Indonesia Tahun 2015 Nomor 57, Tambahan Lembaran Negara Republik Indonesia Nomor 5678).

15 Penjelasan Undang-Undang Nomor 8 Tahun 2015 tentang Perubahan Atas Undang-Undang Nomor 1 Tahun 2015 tentang Penetapan Peraturan Pemerintah Pengganti Undang-Undang Nomor 1 Tahun 2014 tentang Pemilihan Gubernur, Bupati, dan Walikota Menjadi Undang-Undang (Lembaran Negara Republik Indonesia Tahun 2015 Nomor 57, Tambahan Lembaran Negara Republik Indonesia Nomor 5678).

16 Pasal 41 ayat (1) dan (2) Undang-Undang Nomor 8 Tahun 2015 tentang Perubahan Atas Undang-Undang Nomor 1 Tahun 2015 tentang Penetâpan Peraturan Pemerintah Pengganti Undang-Undang Nomor 1 Tahun 2014 tentang Pemilihan Gubernur, Bupati, dan Walikota Menjadi Undang-Undang (Lembaran Negara Republik Indonesia Tahun 2015 Nomor 57, Tambahan Lembaran Negara Republik Indonesia Nomor 5678).

17 Pasal 166 ayat (1) Undang-Undang Nomor 8 Tahun 2015 tentang Perubahan Atas Undang-Undang Nomor 1 Tahun 2015 tentang Penetapan Peraturan Pemerintah Pengganti Undang-Undang Nomor 1 Tahun 2014 tentang Pemilihan Gubernur, Bupati, dan Walikota Menjadi Undang-Undang (Lembaran Negara Republik Indonesia Tahun 2015 Nomor 57, Tambahan Lembaran Negara Republik Indonesia Nomor 5678).

18 Penjelasan Undang-Undang Nomor 8 Tahun 2015 tentang Perubahan Atas Undang-Undang Nomor 1 Tahun 2015 tentang Penetapan Peraturan Pemerintah Pengganti Undang-Undang Nomor 1 Tahun 2014 tentang Pemilihan Gubernur, Bupati, dan Walikota Menjadi Undang-Undang (Lembaran Negara Republik Indonesia Tahun 2015 Nomor 57, Tambahan Lembaran Negara Republik Indonesia Nomor 5678).

19 Pasal 157 ayat (2) Undang-Undang Nomor 8 Tahun 2015 tentang Perubahan Atas Undang-Undang Nomor 1 Tahun 2015 tentang Penetapan Peraturan Pemerintah Pengganti Undang-Undang Nomor 1 Tahun 2014 tentang Pemilihan Gubernur, Bupati, dan Walikota Menjadi Undang-Undang (Lembaran Negara Republik Indonesia Tahun 2015 Nomor 57, Tambahan Lembaran Negara Republik Indonesia Nomor 5678).

20. Pasal 201 ayat (1) Undang-Undang Nomor 8 Tahun 2015 tentang Perubahan Atas Undang-Undang Nomor 1 Tahun 2015 tentang Penetapan Peraturan Pemerintah Pengganti Undang-Undang Nomor 1 Tahun 2014 tentang Pemilihan Gubernur, Bupati, dan Walikota Menjadi Undang-Undang (Lembaran Negara Republik Indonesia Tahun 2015 Nomor 57, Tambahan Lembaran Negara Republik Indonesia Nomor 5678). 
b. Gelombang kedua dilaksanakan Februari 2017 (untuk akhir masa jabatan semester kedua tahun 2016 dan seluruh akhir masa jabatan 2017). ${ }^{21}$

c. Gelombang ketiga dilaksanakan Juni 2018 (untuk akhir masa jabatan tahun 2018 dan akhir masa jabatan 2019). ${ }^{22}$

d. Serentak nasional dilaksanakan tahun 2027. ${ }^{23}$

10. Pengajuan pencalonan dilakukan secara berpasangan, yaitu pasangan Gubernur \& Wakil Gubernur, Bupati \& Wakil Bupati, dan Walikota \& Wakil Walikota secara paket dalam pemilihan secara langsung oleh rakyat. $^{24}$

11. Tentang tambahan syarat calon kepala daerah yang terkait syarat tidak pernah dipidana, disepakati bahwa rumusannya disesuaikan dengan Putusan Mahkamah
Konstitusi sebagaimana yang tercantum dalam rumusan Perppu Pilkada. ${ }^{25}$

Walaupun UU Pilkada memberikan kejelasan penanganan perselisihan hasil Pilkada pada Mahkamah Agung ${ }^{26}$, namun, salah satu poin yang disahkan dalam revisi UU Pilkada adalah mengembalikan penyelesaian sengketa Pilkada kepada Mahkamah Konstitusi dalam masa transisi sampai dibentuknya lembaga peradilan khusus. Hal ini menunjukkan bahwa terdapat legal importance untuk membentuk sebuah pengadilan khusus yang secara spesifik menangani sengketa Pilkada. Terlebih Mahkamah Agung menyatakan menolak penyelesaian sengketa Pilkada. ${ }^{27}$

Berpijak pada dinamika legislasi kekinian dan desain keserentakan Pilkada yang akan dilaksanakan pada bulan Desember 2015, maka tentu saja diperlukan sebuah piranti hukum yang

$21 \quad$ Pasal 201 ayat (2) Undang-Undang Nomor 8 Tahun 2015 tentang Perubahan Atas Undang-Undang Nomor 1 Tahun 2015 tentang Penetapan Peraturan Pemerintah Pengganti Undang-Undang Nomor 1 Tahun 2014 tentang Pemilihan Gubernur, Bupati, dan Walikota Menjadi Undang-Undang (Lembaran Negara Republik Indonesia Tahun 2015 Nomor 57, Tambahan Lembaran Negara Republik Indonesia Nomor 5678).

22 Pasal 201 ayat (3) Undang-Undang Nomor 8 Tahun 2015 tentang Perubahan Atas Undang-Undang Nomor 1 Tahun 2015 tentang Penetapan Peraturan Pemerintah Pengganti Undang-Undang Nomor 1 Tahun 2014 tentang Pemilihan Gubernur, Bupati, dan Walikota Menjadi Undang-Undang (Lembaran Negara Republik Indonesia Tahun 2015 Nomor 57, Tambahan Lembaran Negara Republik Indonesia Nomor 5678).

23 Pasal 201 ayat (7) Undang-Undang Nomor 8 Tahun 2015 tentang Perubahan Atas Undang-Undang Nomor 1 Tahun 2015 tentang Penetapan Peraturan Pemerintah Pengganti Undang-Undang Nomor 1 Tahun 2014 tentang Pemilihan Gubernur, Bupati, dan Walikota Menjadi Undang-Undang (Lembaran Negara Republik Indonesia Tahun 2015 Nomor 57, Tambahan Lembaran Negara Republik Indonesia Nomor 5678).

24 Pasal 39 Undang-Undang Nomor 8 Tahun 2015 tentang Perubahan Atas Undang-Undang Nomor 1 Tahun 2015 tentang Penetapan Peraturan Pemerintah Pengganti Undang-Undang Nomor 1 Tahun 2014 tentang Pemilihan Gubernur, Bupati, dan Walikota Menjadi Undang-Undang (Lembaran Negara Republik Indonesia Tahun 2015 Nomor 57, Tambahan Lembaran Negara Republik Indonesia Nomor 5678).

25 Penjelasan Pasal 7 huruf g Undang-Undang Nomor 8 Tahun 2015 tentang Perubahan Atas Undang-Undang Nomor 1 Tahun 2015 tentang Penetapan Peraturan Pemerintah Pengganti Undang-Undang Nomor 1 Tahun 2014 tentang Pemilihan Gubernur, Bupati, dan Walikota Menjadi Undang-Undang (Lembaran Negara Republik Indonesia Tahun 2015 Nomor 57, Tambahan Lembaran Negara Republik Indonesia Nomor 5678).

26 Pasal 156-159 Undang-Undang Nomor 1 Tahun 2015 tentang Penetapan Peraturan Pemerintah Pengganti Undang-Undang Nomor 1 Tahun 2014 tentang Pemilihan Gubernur, Bupati, dan Walikota Menjadi UndangUndang (Lembaran Negara Republik Indonesia Tahun 2015 Nomor 23, Tambahan Lembaran Negara Republik Indonesia Nomor 5656).

27 Suryanta Bakti Susila dan Agus Rahmat, "Akan Dibentuk Peradilan Khusus Sengketa Pilkada", http://politik.news. viva.co.id/news/read/590742-akan-dibentuk-peradilan-khusus-sengketa-pilkada, (diakses 11 Maret 2015). 
dapat mendukung pelaksanaan Pilkada serentak tersebut. Salah satunya yang dibutuhkan adalah keberadaan lembaga adjudikasi yang dapat dan mampu menyelesaikan persengketaan dan perselisihan hasil Pilkada. Desain penyelesaian sengketa Pilkada adalah melalui Majelis Khusus Tindak Pidana ${ }^{28}$ dan Majelis Khusus Tata Usaha Negara ${ }^{29}$ yang semula diatur pada UU Pilkada dinilai tidak dapat menjawab kompleksitas Pilkada terlebih dengan penolakan Mahkamah Agung untuk melaksanakan kewenangan tersebut dan "keengganan" Mahkamah Konstitusi dengan "melepaskan" kewenangan tersebut melalui Putusan Mahkamah Konstitusi Nomor 97/PUU-XI/2013 ${ }^{30}$.

Sebelum sengketa Pilkada dilimpahkan ke Mahkamah Agung dalam UU Pilkada, data Mahkamah Konstitusi menyebutkan bahwa sejak Tahun 2008-2014, terdapat 689 gugatan hasil Pilkada yang harus diperiksa Mahkamah Konstitusi dalam waktu singkat. ${ }^{31}$ Terlebih, data Kementerian Dalam Negeri Indonesia menyebutkan bahwa pada tahun 2015 sebagai masa transisi Pilkada serentak jumlah Pilkada yang akan diselenggarakan serentak bertahap mencapai 205 Pilkada. ${ }^{32}$
Untuk menghadapi hal tersebut, dalam UU Pilkada kewenangan penyelesaian sengketa diletakkan sebatas pada Majelis Khusus Tindak Pidana dan Majelis Khusus Tata Negara. Hal yang patut dikritisi karena pembentukan Majelis Khusus Tindak Pidana dan Majelis Khusus Tata Usaha Negara masih menyimpan sisi kelemahan, pasalnya melalui kedua majelis tersebut penyelesaian sengketa Pilkada masih berada pada lembaga-lembaga yang terpisah, yakni di Peradilan Umum dan Peradilan Tata Usaha Negara. Dengan mempertahankan desain tersebut, tantangannya kemudian adalah kesulitan memenuhi ketepatan waktu penyelesaian sengketa yang akan kontraproduktif dengan keharusan penyelesaian sengketa Pilkada untuk diselesaikan dalam waktu singkat.

Berbekal kondisi di atas, harus dipikirkan sebuah lembaga adjudikasi yang mampu menyelesaikan sengketa dan perselisihan Pilkada dengan lebih efisien, efektif, dan berkeadilan. $\mathrm{Hal}$ ini penting untuk menjadikan Pilkada sebagai pesta demokrasi di daerah yang tidak kehilangan makna sebagai semata rangkaian semantis tanpa esensi cita rasa demokratis.

28 Pasal 151 Undang-Undang Nomor 1 Tahun 2015 tentang Penetapan Peraturan Pemerintah Pengganti UndangUndang Nomor 1 Tahun 2014 tentang Pemilihan Gubernur, Bupati, dan Walikota Menjadi Undang-Undang (Lembaran Negara Republik Indonesia Tahun 2015 Nomor 23, Tambahan Lembaran Negara Republik Indonesia Nomor 5656).

29 Pasal 155 Undang-Undang Nomor 1 Tahun 2015 tentang Penetapan Peraturan Pemerintah Pengganti UndangUndang Nomor 1 Tahun 2014 tentang Pemilihan Gubernur, Bupati, dan Walikota Menjadi Undang-Undang (Lembaran Negara Republik Indonesia Tahun 2015 Nomor 23, Tambahan Lembaran Negara Republik Indonesia Nomor 5656).

30 Putusan Mahkamah Konstitusi Nomor 97/PUU-XI/2013 perihal Pengujian Undang-Undang Nomor 12 Tahun 2008 tentang Perubahan Kedua Atas Undang-Undang Nomor 32 Tahun 2004 tentang Pemerintahan Daerah dan Undang-Undang Nomor 48 Tahun 2009 tentang Kekuasaan Kehakiman terhadap Undang-Undang Dasar Negara Republik Indonesia Tahun 1945, hlm. 60.

31 Pendapat Ahmad Fadil Sumadi dalam Putusan Mahkamah Konstitusi Nomor 97/PUU-XI/2013 perihal Pengujian Undang-Undang Nomor 12 Tahun 2008 tentang Perubahan Kedua Atas Undang-Undang Nomor 32 Tahun 2004 tentang Pemerintahan Daerah dan Undang-Undang Nomor 48 Tahun 2009 tentang Kekuasaan Kehakiman terhadap Undang-Undang Dasar Negara Republik Indonesia Tahun 1945.

32 Surat Kementerian Dalam Negeri Republik Indonesia Nomor 120/4474/OTDA perihal Konfirmasi Data Akhir Masa Jabatan Kepala Daerah Tahun 2015, tanggal 29 Oktober 2014. 
Inisiasi pembentukan suatu lembaga adjudikasi khusus sangat tepat dipikirkan sebagai bentuk pembaharuan hukum dalam era otonomi daerah pada masa kepemimpinan JokowiJK saat ini, sebagai bentuk persiapan menuju Pilkada serentak tahun 2020, sehingga ke depan tercipta Pilkada, yang bukan semata demokratis, namun juga berkeadilan.

Berdasarkan latar belakang sebagaimana yang telah dikemukakan di atas, terdapat berbagai rumusan permasalahan, yakni: (a) Bagaimana urgensi pembentukan pengadilan khusus Pilkada di Indonesia? (b) Bagaimana perbandingan pengadilan khusus Pilkada di beberapa negara lain? dan (c) Bagaimana relevansi perbandingan tersebut dapat diterapkan di Indonesia?

\section{B. Metode Penelitian}

\section{Sifat Penelitian}

Penulisan ini merupakan penelitian hukum (legal research) dikarenakan secara spesifik menggunakan logika berpikir hukum dalam menganalisis permasalahan. Penelitian hukum ini berfokus mengkaji urgensi dan relevansi pengadilan khusus Pilkada sebagai sebuah inisiasi yang diperlukan untuk memprevensi penyelesaian sengketa dalam keserentakan Pilkada di Indonesia. Lebih lanjut dalam rangka mendapatkan informasi yang diperlukan dalam penelitian ini, sehingga dapat digunakan untuk menganalisis permasalahan hukum yang sedang dikaji, maka digunakan beberapa pendekatan yang lazim digunakan dalam penelitian hukum, yaitu pendekatan perundang-undangan (statute approach), pendekatan kasus (case approach), dan pendekatan konseptual (conceptual approach). ${ }^{33}$ Pendekatan-pendekatan tersebut digunakan untuk menjawab fokus penelitian.

Beberapa pendekatan yang digunakan dalam penelitian ini adalah: Pertama, pendekatan perundang-undangan (statute approach). Penelitian hukum dalam level dogmatik hukum atau penelitian untuk keperluan praktik hukum tidak dapat melepaskan diri dari pendekatan peraturan perundang-undangan. ${ }^{34}$ Dalam penelitian hukum ini, dikarenakan terkait dengan penyelesaian sengketa Pilkada, maka dirujuk berbagai peraturan yang terkait dengan kekuasaan kehakiman dan pemerintahan daerah merupakan suatu pendekatan yang mutlak harus digunakan. Perspektif peraturan perundang-undangan digunakan untuk menilai bagaimana pengaturan mengenai penyelesaian sengketa Pilkada yang didesainkan saat ini sebagai titik fokus penelitian ini.

Kedua, pendekatan konseptual (conceptual approach). Setelah mengetahui mengenai desain pengaturan, maka selanjutnya penelitian bergeser menggunakan pendekatan konseptual untuk menilai dan memahami bagaimana aspek teoritis terhadap konsepsi penyelesaian sengketa Pilkada. Pendekatan konseptual beranjak dari pandangan-pandangan dan doktrin-doktrin yang berkembang di dalam ilmu hukum. ${ }^{35}$ Ketiga, pendekatan kasus (case approach). Pendekatan kasus dalam penelitian ini digunakan untuk menilai praktik penyelesaian sengketa Pilkada di beberapa negara. Dengan demikian, dapat dilihat praktik terbaik (best practices) dari pengadilan khusus dalam menyelesaikan sengketa Pilkada atau yang sejenis.

\footnotetext{
33 Peter Mahmud Marzuki, Penelitian Hukum (Jakarta: Kencana, 2005), hlm. 93.

34 Ibid., hlm. 96.

35 Ibid., hlm. 95.
} 


\section{Cara Penelitian}

Meminjam klasifikasi yang dibuat oleh Amiruddin dan Zainal Asikin, maka penelitian hukum ini pada dasarnya digolongkan dalam penelitian hukum normatif, ${ }^{36}$ karena dalam penelitian hukum ini, hukum dikonsepkan sebagai apa yang tertulis dalam peraturan perundang-undangan (law in books) atau hukum dikonsepkan sebagai kaidah atau norma yang merupakan patokan berperilaku manusia yang dianggap pantas. ${ }^{37}$ Dalam kategorisasi yang lain menurut Ronny Hanitijo Soemitro, penelitian ini dapat dikategorikan dalam penelitian hukum normatif terhadap asas-asas hukum. ${ }^{38}$ Dalam penelitian hukum normatif digunakan penelitian hukum kepustakaan, ${ }^{39}$ yaitu mendapatkan data sekunder dengan bahan atau materi berupa buku, artikel, hasil penelitian, dan peraturan perundang-undangan, serta pendapat ahli yang berkaitan tentang berkaitan dengan fokus penelitian.

\section{Jenis Data}

Sebagaimana telah disebutkan di atas bahwa penelitian ini adalah penelitian hukum normatif yang menitikberatkan pada penelitian hukum kepustakaan. Oleh karena itu, salah satu ciri utama dari penelitian hukum kepustakaan adalah menggunakan sumber data sekunder, yang terdiri dari bahan hukum primer, bahan hukum sekunder, dan bahan hukum tersier. ${ }^{40}$ Bahan Hukum Primer, yaitu bahan-bahan hukum atau ketentuan yang mengikat, ${ }^{41}$ dan peraturan perundang-undangan yang pernah berlaku yang berkaitan dengan objek penelitian.

Bahan Hukum Sekunder, yaitu bahan yang memberikan penjelasan mengenai bahan-bahan hukum primer, ${ }^{42}$ atau teks yang berisi mengenai prinsip-prinsip dasar ilmu hukum dan pandangan-pandangan klasik para sarjana yang mempunyai kualifikasi tinggi, ${ }^{43}$ atau bahan-bahan yang erat hubungannya dengan bahan hukum primer dan dapat membantu menganalisa dan memahami bahan hukum primer, ${ }^{44}$ antara lain semua dokumen yang terkait obyek penelitian yang tersebar dalam buku, majalah, surat kabar atau internet, makalah hasil seminar, dan hasil penelitian terdahulu yang sejenis dengan obyek penelitian. Sedangkan, Bahan Hukum Tersier, mencakup bahan-bahan yang memberikan petunjuk terhadap bahan hukum primer dan hukum sekunder. ${ }^{45}$

\section{Analisis Data}

Analisis data sebagai tindak lanjut proses pengolahan data merupakan kerja seorang peneliti yang memerlukan ketelitian, dan pencurahan daya pikir secara optimal. ${ }^{46}$ Analisis

\footnotetext{
Amiruddin dan Zainal Asikin, Pengantar Metode Penelitian Hukum (Jakarta: RajaGrafindo Persada, 2004), hlm. 29.

37 Ibid., hlm. 118.

38 Ronny Hanitijo Soemitro, Metodologi Penelitian Hukum dan Jurimetri (Jakarta: Ghalia Indonesia, 1988$)$, hlm. 15.

39 Soerjono Soekanto dan Sri Mamudji, Penelitian Hukum Normatif Suatu Tinjauan Umum (Jakarta: RajaGrafindo Persada, 2007), hlm. 23.

40 Amiruddin dan Zainal Asikin, Loc.cit.

Peter Mahmud Marzuki, Op.cit., hlm. 142.

44 Ronny Hanitijo Soemitro, Metodologi Penelitian Hukum (Jakarta: Ghalia Indonesia, 1985), hlm. 25.

45 Soerjono Soekanto dan Sri Mamudji, Op.cit., hlm. 33.

46 Bambang Waluyo, Penelitian Hukum dalam Praktik (Jakarta: Sinar Grafika, 2002), hlm. 77.
}

41 Ibid.

42 Ibid. 
data berisi uraian tentang cara-cara analisis, yaitu bagaimana memanfaatkan data yang terkumpul untuk dipergunakan dalam memecahkan masalah penelitian atau merupakan penjelasan mengenai proses memanfaatkan data yang terkumpul untuk selanjutnya digunakan dalam memecahkan masalah penelitian. ${ }^{47}$

Metode pengolahan data yang digunakan adalah dengan mengumpulkan data yang diperoleh dari penelitian kepustakaan, yang kemudian diolah menggunakan metode kualitatif. Sebagai penelitian hukum normatif, maka data yang terkait dengan penulisan hukum ini dianalisis secara deskriptif kualitatif, yaitu dengan melakukan analisis yang pada dasarnya dikembalikan pada tiga aspek, yaitu mengklasifikasi, membandingkan, dan menghubungkan. ${ }^{48}$ Dengan perkataan lain, seorang peneliti yang mempergunakan metode kualitatif, tidaklah semata-mata bertujuan mengungkapkan kebenaran belaka, akan tetapi untuk memahami kebenaran tersebut. ${ }^{49}$ Suatu analisis yuridis normatif pada hakikatnya menekankan pada metode deduktif sebagai pegangan utama, ${ }^{50}$ yaitu proses berpikir yang dimulai dari pernyataan yang umum menuju pernyataan yang khusus (spesifik) dengan menggunakan logika yang dapat diterima.

Selain itu, dalam mengolah dan menganalisis data yang ada, Peneliti juga menggunakan penafsiran (interpretasi) yang dikenal dalam ilmu hukum. Penafsiran tersebut diperlukan dalam rangka penggalian makna, sehingga apa yang dibaca bukan hanya diartikan secara tekstual, namun dimaknai secara kontekstual untuk menggali makna baik yang tersurat maupun yang tersirat. Ketepatan pemahaman (subtilitas intellegendi) dan ketepatan penjabaran (subtilitas explicandi) adalah sangat relevan bagi hukum. ${ }^{51}$

\section{Pembahasan}

\section{Urgensi Pembentukan Pengadilan Khusus Pilkada}

Gagasan mengenai pengadilan khusus Pilkada menjadi hal yang relevan untuk dipertimbangkan karena upaya hukum dalam proses Pilkada yang telah terjadi selama ini seringkali tidak dapat memenuhi rasa keadilan masyarakat, misalnya putusan pengadilan yang baru diputus pasca tahapan Pilkada telah selesai dilaksanakan dan berlapis-lapisnya upaya hukum Pilkada sehingga kontraproduktif dengan tahapan Pilkada yang dibatasi oleh jangka waktu. Terlebih upaya hukum tersebut terpisah dalam beberapa lingkungan peradilan. Dengan kondisi tersebut, upaya hukum terhadap tahapan Pilkada menghadapi tantangan lebih lanjut dengan pelaksanaan Pilkada serentak karena tahapan proses pemilihan dan upaya hukum atas setiap tahapan pemilihan tersebut akan dilaksanakan secara bersamaan, sehingga bila menggunakan mekanisme peradilan sebagaimana hukum positif saat ini tentu mewujudkan Pilkada yang berkeadilan akan sulit untuk diwujudkan.

7 Maria S.W. Sumardjono, Pedoman Pembuatan Usulan Penelitian: Sebuah Panduan Dasar (Jakarta: Gramedia, 2001), hlm. 38.

48 Jujur S. Suriasumantri, Ilmu dalam Perspektif Moral, Sosial dan Politik: Sebuah Dialog tentang Keilmuan Dewasa Ini (Jakarta: Gramedia, 1986), hlm. 61-62.

49 Soerjono Soekanto, Op.cit., hlm. 250.

50 Ibid., hlm. 164.

51 Ibid., hlm. 164. 
Hal yang patut dikritisi adalah bahwa pembentukan Majelis Khusus Tindak Pidana dan Majelis Khusus Tata Usaha Negara masih menyimpan sisi kelemahan karena melalui kedua majelis tersebut penyelesaian sengketa pilkada masih berada pada lembagalembaga yang terpisah, yakni di Peradilan umum dan Peradilan Tata Usaha Negara. Dengan mempertahankan desain tersebut, tantangannya kemudian adalah kesulitan memenuhi ketepatan waktu penyelesaian sengketa yang akan kontraproduktif dengan keharusan penyelesaian sengketa Pilkada untuk diselesaikan dalam waktu singkat.

Patut diingat, sebelum Pilkada diselenggarakan secara serentak saja, permasalahan ketepatan waktu putusan lembaga adjudikasi menjadi hal yang menyebabkan gagalnya negara memenuhi hak konstitusional warga negara. Sebagai contoh adalah pada kasus gugatan PTUN yang diajukan oleh Rudolf Pardede dan Affifudin Lubis di Kota Medan. Pada waktu itu, Putusan PTUN dikeluarkan ketika telah melewati rentang penetapan pasangan calon, padahal gugatan yang diajukan oleh Rudolf Pardede dan Affifudin Lubis adalah tentang hak mereka untuk ditetapkan sebagai pasangan calon. ${ }^{52}$ Akhirnya Putusan PTUN tersebut tidak dieksekusi oleh KPU Kota Medan dengan alasan tahap penetapan calon sudah lewat. Yang lebih menyebabkan kacau, Putusan TUN tersebut bahkan beberapa kali mendasari permohonan Pemohon sebagai bakal calon kepala daerah untuk memiliki legal standing berperkara di Mahkamah Konstitusi.

\section{Pengadilan Khusus Pemilu di Beberapa Negara}

Dalam mendesain Pengadilan Khusus Pilkada di Indonesia, perlu dikaji beberapa komparasi dengan berbagai negara yang telah memiliki pengadilan pemilu. Berdasarkan penelusuran Penulis, terdapat banyak negara yang telah menerapkan Pengadilan Pemilu, seperti Uruguay, Brazil, Costa Rica, Nigeria, dan Meksiko. Negara-negara di Amerika Latin dan Afrika tersebut mayoritas menggabungkan kewenangan administrasi pemilu (election administration) dengan adjudikasi sengketa (election complaints adjudication). ${ }^{53}$ Dengan memperhatikan konteks desain kekuasaan kehakiman dan kelembagaan penyelenggara Pemilu, maka Penulis memilih 3 (tiga) negara yang relatif relevan untuk dijadikan perbandingan dalam menginisiasi Pengadilan Pemilu, yakni Uruguay, Brazil, dan Costa Rica.

\section{a) Corte Electoral di Uruguay}

República Oriental del Uruguay merdeka pada tahun 1825 memiliki kombinasi quasipresidentialism dan sistem multipartai. Electoral Law 1924 menandai terbentuknya badan manajemen pemilu yang otonom dan mandiri, yang sebelumnya hampir satu abad penyelesaian sengketa berada di tangan eksekutif, akhirnya dibentuk yurisdiksi Corte Electoral (Pengadilan Pemilu) yang independen dan permanen, yang mana pada tahun 1934 keberadaan dan kewenangan Pengadilan Pemilu yang dituangkan dalam Konstitusi Uruguay. 
Sejak tahun 1924, Uruguay merupakan negara yang telah memiliki pengadilan khusus untuk menangani sengketa pemilu. ${ }^{54}$ Ini menunjukkan bahwa Uruguay sudah cukup lama mendirikan pengadilan pemilu, sehingga relevan bagi Indonesia untuk menjadikannya sebagai benchmarking ketika akan mendirikan pengadilan pemilu. Selain alasan tersebut, Uruguay juga memiliki beberapa kesamaan karakter dengan Indonesia, yakni menganut sistem multi partai. Mekanisme Pemilu di Uruguay pun bertingkat sesuai wilayah, yakni Pemilu di tingkat negara dan Pemilu di tingkat Departamental ${ }^{55}$, sama dengan Indonesia yang memiliki mekanisme Pemilu di tingkat nasional dan Pemilu di tingkat daerah.

Secara kelembagaan, Electoral Court di Uruguay berdiri secara permanen dan terdiri dari Pengadilan Pemilu di tingkat nasional yang disebut Electoral Court dan Pengadilan Pemilu di tingkat daerah yang disebut dengan Electoral Boards (Juntas Electorales). ${ }^{56}$ Masing-masing dari Electoral Court dan Electoral Boards dibantu oleh kantor sekretariat yang khusus menangani permasalahan administratif seperti pegawai dan segala hal terkait pembiayaan Pengadilan Pemilu. Kantor sekretariat ini di tingkat nasional disebut National Electoral Office, sedangkan di tingkat lokal disebut Departmental Electoral Office. ${ }^{57}$ Dikarenakan bersifat subordinat antara organisasi tingkat nasional dan Departemen, maka Electoral Boards wajib selalu melaporkan kegiatannya pada Electoral Court, demikian pula Departmental Electoral Office diwajibkan melaporkan kegiatannya pada National Electoral Office. ${ }^{58}$

Kewenangan dari Electoral Court sebagaimana disebutkan dalam Konstitusi Uruguay mencakup 3 (tiga) hal, yakni: (a) bertanggung jawab membuat peraturan tentang pemilu dan mengawasi pelaksanaannya (to act in all matters relating to electoral acts or procedures); (b) menjadi pusat koordinasi segala hal terkait pemilu termasuk mengenai pembiayaan pemilu (to exercise directive, disciplinary, advisory, and economic supervision over electoral organs); dan (3) Memutus sengketa hasil pemilu (to render final decision on all appeals and claims that may arise and act as judge of the elections to all elective offices, and of plebiscites and referendums). ${ }^{59}$

Dikarenakan bersifat subordinat, maka kewenangan Electoral Boards merupakan bagian kewenangan Electoral Court yang terbatas pada level daerah. Kewenangan Pengadilan Pemilu di Uruguay tersebut tampak sangat luas mencakup segala hal terkait pemilu mulai dari pembuatan regulasinya, pelaksanaannya, sampai penyelesaian sengketanya. Hal ini kemudian menjadikan Pengadilan Pemilu Uruguay diistilahkan sebagai cabang keempat negara karena mampu mengambil alih fungsi legislatif, eksekutif, dan yudikatif. ${ }^{60}$

\footnotetext{
54 Country Studies US, "The Consolidation of Political Democracy", http://countrystudies.us/uruguay/13.htm, (diakses 4 Maret 2015).

55 Departamental adalah wilayah setingkat dengan Provinsi.

56 Chad Vickery (Ed.), Op.cit., hlm. 124.

57 Sara Staino, "Case Study: Uruguay: The Electoral Court - A Fourth Branch of Government?", dalam Alan Wall, et al., Electoral Management Design: The International IDEA Handbook (Stockholm: IDEA, 2006), hlm. 219.

58 Ibid.

59 Article 322 of the Constitution of Uruguay 1966 (reinst. 1985, rev. 2004).

60 Sara Staino, "Case Study: Uruguay: The Electoral Court - A Fourth Branch of Government?", Loc.cit.
} 
Electoral Court memiliki anggota berjumlah 9 (sembilan) orang yang dipilih oleh anggota 2 (dua) kamar Parlemen Uruguay. ${ }^{61}$ Sembilan orang ini, lima merupakan orang-orang nonpartai politik yang dipilih berdasarkan keahlian profesional (based on professional skill). ${ }^{62}$ Untuk dapat menentukan lima orang terpilih tersebut, pemungutan suara di parlemen harus setidaktidaknya mampu mengumpulkan $2 / 3$ suara keseluruhan anggota.63 Sedangkan untuk menentukan empat orang anggota sisanya, mekanismenya dilakukan melalui pemilihan dengan sistem proporsional oleh anggota partai politik pemimpin dalam parlemen. ${ }^{64}$

\section{b) Tribunal Superior Eleitoral di Brazil}

Penegakan hukum Pemilu di Brazil baru mulai dengan pembentukan Pengadilan Khusus Pemilu pada tahun 1932, walaupun Pemilu pertama di Brazil dilaksanakan pada tahun 1821 ketika Brazil masih menjadi negara jajahan Portugis. ${ }^{65}$ Brazil memiliki dua jenis Pemilu, yakni Pemilu di tingkat negara federal dan Pemilu di wilayah negara bagian. Diperbandingkan dengan Indonesia yang berbentuk negara kesatuan, tentu mekanisme Pemilunya berbeda, namun dilihat dari sistem kepartaian baik Indonesia maupun Brazil memiliki kesamaan menganut multipartai, sehingga hal ini pun akan berpengaruh terhadap jalannya Pemilu.
Pengadilan Pemilu di Brazil merupakan bagian dari Electoral Justice System, yaitu: (a) Superior Electoral Tribunal; (b) Regional Electoral Tribunals; (c) Electoral Judges; dan (d) Electoral Boards. ${ }^{66}$ Pengadilan Pemilu di Brazil dibentuk secara permanen dalam 2 (dua) tingkat, yakni pengadilan pemilu di tingkat negara federal yang disebut Superior Electoral Tribunal dan Regional Electoral Tribunals di setiap negara bagian ${ }^{67}$. Pengadilan Pemilu di Brazil merupakan penggabungan dari badan adjudikatif (adjudicative body) dan badan manajemen Pemilu (electoral management body). 68

Komposisi hakim pada Superior Electoral Tribunal terdiri dari 7 (tujuh) hakim dengan komposisi 5 (lima) hakim, yang dipilih 3 (tiga) hakim dari Supreme Federal Tribunal dan 2 (dua) hakim dari Superior Tribunal of Justice, sedangkan 3 (dua) hakim lagi ditunjuk oleh Presiden dengan latar belakang advokat. ${ }^{69}$ Sedangkan hakim pada Regional Electoral Tribunal terdiri dari 7 (tujuh) hakim dengan komposisi 4 (empat) hakim, yang dipilih 2 (dua) hakim dari Tribunals of Justice dan 2 (dua) hakim dari pengadilan negara bagian yang ditunjuk oleh Tribunals of Justice, sedangkan komposisi 3 (tiga) hakim, yang dipilih 1 (satu) hakim dari Federal Regional Tribunal dan 2 (dua) hakim lagi ditunjuk oleh Presiden dengan latar belakang advokat. $^{70}$

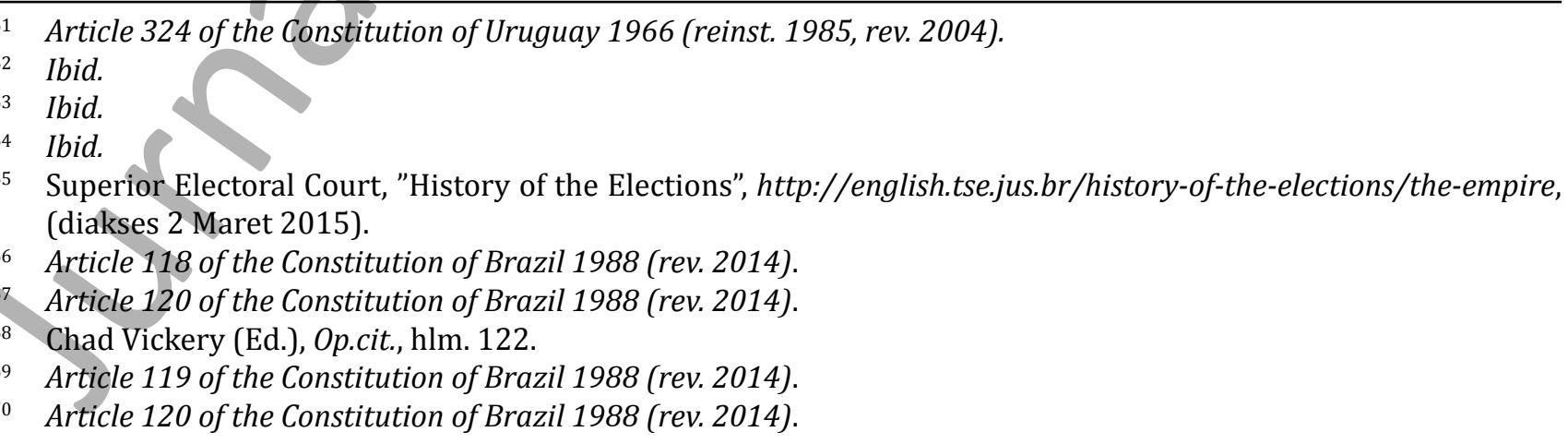


Putusan Superior Electoral Tribunal tidak dapat diajukan banding, sehingga bersifat final dan mengikat. ${ }^{71}$ Adapun demikian terdapat pengecualian putusan-putusan yang dapat diajukan banding, yaitu: (a) they contravene an express provision of this Constitution or law; (b) a divergence exists in the interpretation of a law between two or more electoral courts; (c) they deal with ineligibility or issuance of certificates of election in federal or state elections; (d) they annul certificates of election or decree the loss of federal or state elective offices; dan (e) they deny habeas corpus, writ of security, habeas data or a mandate of injunction. ${ }^{72}$

\section{c) Tribunal Supremo de Elecciones di Costa Rica}

Tribunal Supremo de Elecciones berdiri tahun 1946 dan dimasukkan dalam Konstitusi Costa Rica pada tahun 1949 dan diberikan kekuasaan penuh untuk menyelenggarakan Pemilu Pemilu Presiden, Pemilu Legislatif, dan Pemilu Lokal. ${ }^{73}$ Hal tersebut menunjukkan bahwa tipologi Pemilu yang ada di Costa Rica relatif hampir sama dengan Indonesia. Selain itu, Costa Rica juga menganut sistem pemerintahan presidensial ${ }^{74}$ dengan sistem multipartai. Ditinjau dari sisi ini, maka komparasi antara Indonesia dan Costa Rica menjadi relevan untuk dilakukan.

Jika ditinjau dari sisi kewenangan, Pengadilan ini mirip dengan Uruguay maupun Brazil yang memiliki kewenangan menggabungkan urusan administrasi pemilu maupun urusan adjudikasi pemilu, yang secara eksplisit disebutkan dalam Konstitusi Costa Rica. ${ }^{75}$ Berdasarkan luasnya kewenangan yang dimiliki oleh Tribunal Supremo de Elecciones, pengadilan ini dikenal sebagai the Most Prestigious Institutions in the Country karena menjalankan dan mengkoordinasikan segala hal terkait Pemilu mulai dari menjadi lembaga legislatif, eksekutif, hingga yudikatif. ${ }^{76}$

Kewenangan ini makin bertambah besar karena putusan Tribunal Supremo de Elecciones bersifat final sehingga tidak dapat diganggu gugat. ${ }^{77}$ Namun demikian, dengan kewenangan besar tersebut Pengadilan ini tetap dikelola secara mandiri, imparsial, dan transparan. ${ }^{78}$ Dalam menjalankan kewenangan Tribunal Supremo de Elecciones tersebut terdapat hakim yang terdiri dari 9 (sembilan) hakim utama dengan 6 (enam) hakim pengganti yang dipilih oleh Supreme Court of Justice. ${ }^{79}$

\section{Relevansi Perbandingan Pengadilan Khusus Pemilu untuk Diterapkan Menjadi Desain Pengadilan Khusus Pilkada di Indonesia}

Berdasarkan pada perbandingan Uruguay, Brazil, dan Costa Rica yang telah membentuk Pengadilan Khusus Pemilu, hal ini menunjukkan bahwa kelembagaan adjudikasi khusus untuk Pemilu bukanlah sebuah hal yang tabu untuk diadakan. Terlebih dengan beberapa kesamaan

\footnotetext{
Article 120 paragraph (3) of the Constitution of Brazil 1988 (rev. 2014).

Article 120 paragraph (4) of the Constitution of Brazil 1988 (rev. 2014).

Chad Vickerey (Ed.), Op.cit., hlm. 122.

Article 130 of the Constitution of Costa Rica 1949 (rev. 2011).

Article 102 of the Constitution of Costa Rica 1949 (rev. 2011).

76 Rubén Hernández Valle, "Case Study: Costa Rica: A Powerful Constitutional Body", dalam Alan Wall, et al., Electoral Management Design: The International IDEA Handbook (Stockholm: IDEA, 2006), hlm. 77.

7 Article 102 of the Constitution of Costa Rica 1949 (rev. 2011).

78 Chad Vickerey (Ed.), Op.cit., hlm. 123.

79 Article 100 of the Constitution of Costa Rica 1949 (rev. 2011).
} 
yang dimiliki, baik dari sistem pemerintahan, desain konstitusionalisme, atau bahkan kemapanan dan konsolidasi demokrasi, ${ }^{80}$ perbandingan di atas relevan untuk menjadi benchmarking bagi Indonesia dalam mendesain pengadilan khusus Pilkada, yang tentu saja memiliki identitas ciri tertentu sebagai bentuk rekayasa hukum (legal engineering) dalam praktik ketatanegaraan Indonesia. Rekayasa hukum ini diharapkan dapat membuat konstruksi hukum untuk menuntaskan kebutuhan praktis. ${ }^{81}$

Penggunaan istilah legal engineering merupakan sebuah terminologi yang belum jamak dikenal oleh ahli hukum di Indonesia. Secara sederhana sebenarnya terminologi legal engineering atau rekayasa hukum dipergunakan untuk menggambarkan bagaimana hukum membentuk perubahan sosial. ${ }^{82}$ Jan M. Smits memberikan pemaknaan atas legal engineering sebagai berikut, "As social engineering refers to our ability to engineer a social process (to change society), legal engineering refers to such social engineering through law." ${ }^{83}$

Pola pikir rekayasa hukum sejatinya berpedoman dari perspektif comparative law yang berusaha membuat alternatif solusi dengan memperbandingkan hukum. Dalam hal ini, dari legal engineering (rekayasa hukum) diwujudkan dalam dua nomenklatur, yaitu legal transplants ${ }^{84}$ (transplantasi hukum) dan legal bridges $^{85}$ (jembatan hukum), sebagai produk yang dihasilkan oleh penelitian hukum komparatif (comparative law research)..$^{85} \mathrm{Hal}$ tersebut sejalan dengan pendapat Roscoe Pound yang menyatakan, "history of a system of law is largely a history of borrowings of legal materials from other legal systems and of assimilation of materials from outside of the law". ${ }^{86}$ Bahwa sistem hukum sebagian besar

80 Chad Vickerey (Ed.), Op.cit., hlm. 125. Lihat juga Denis Petit, "Resolving Election Disputes in the OSCE Area: Towards a Standard Election Dispute Monitoring System", (ODIHR Rule of Law Expert, Warsaw, 2000).

81 Eleanor Cashin Ritaine, "Legal Engineering in Comparative Law - An Introduction", dalam Eleanor Cashin Ritaine (Ed.), Legal Engineering and Comparative Law (L'ingénierie juridique et le droit comparé) (Genève: Schulthess, 2009), hlm. 9.

82 John H. Beckstrom, "Handicaps of Legal-Social Engineering in a Developing Nation", American Journal of Comparative Law 22: 4 (1974): 697. Lebih lanjut lihat dalam Harry V. Ball dan Lawrence M. Friedman, "The Use of Criminal Sanctions in the Enforcement of Economic Legislation: A Sociological View", Stanford Law Review 17:2, (Jan., 1965): 220.

83 Jan M. Smits, "Legal Engineering in an Age of Globalisation: Is There a Future for Jurisdictional Competition?", dalam Eleanor Cashin Ritaine (Ed.), Legal Engineering and Comparative Law (L'ingénierie juridique et le droit comparé) (Genève: Schulthess, 2009), hlm. 52.

84 Máximo Langer memilih untuk menggunakan metafora "legal translation", dengan alasan, "The metaphor of the "legal transplant" has been the main device used by comparative law scholars and practitioners when analysing the importation of foreign legal practices. This metaphor, however, has its shortcomings. Its chief problem is that it conveys the notion that legal ideas and institutions can simply be "cut and pasted" between legal systems. Thus, this metaphor fails to account for the transformation that legal ideas and institutions may undergo when they are transferred between legal systems. In this Article, I propose the metaphor of the "legal translation" as an alternative heuristic device to employ when analysing the transfer of legal ideas and institutions between legal systems. The adversarial and the inquisitorial systems, understood as two different procedural cultures, can be understood as two different systems of production of meaning. Thus, the transfer of legal institutions from one system to the other can be understood as translations from one system of meaning to the other." Lihat dalam Máximo Langer, "From Legal Transplants to Legal Translations: The Globalization of Plea Bargaining and the Americanization Thesis in Criminal Procedure", Harvard International Law Journal 45: 1 (Winter 2004): 5.

85 Ibid., hlm. 21-22.

86 Roscoe Pound, The Formative Era of American Law, (Boston: Little, Brown, and Co., 1938), hlm. 94. 
merupakan "pinjaman" dari sistem hukum lain dan percampuran dengan hal-hal di luar hukum.

Transplantasi hukum dipilih oleh suatu negara akan berdampak pada kehidupan sosial ekonomi negara tersebut dengan melihat legal effectiveness ${ }^{87}$ sebagai suatu long term effect penerapan transplantasi hukum yang dipilih. Hal tersebut relevan, mengingat yang dapat ditransplantasikan antara lain berupa institusi (institutions), kebijakan (policies), program (programmes), prosedur (procedures), ideologi (ideologies), pembenaran (justifications), sikap (attitudes), dan ide (ideas). ${ }^{88}$ Pada sisi yang lain, pilihan untuk melakukan transplantasi hukum haruslah didesain dengan cermat untuk menghindari adanya kegagalan atau bahkan penolakan dari sistem yang hendak ditransplantasikan. ${ }^{89}$

Dalam konteks berpikir hukum publik, secara sederhana legal transplants dapat dikatakan sebagai bentuk insersi dari foreign legat solutions terhadap sistem hukum negara lain, atau dapat disebut juga sebagai legal import ${ }^{90}$. Namun, tentu hal ini menjadi hal yang sensitif dikaitkan dengan perspektif kedaulatan negara. Bagaimanapun hukum merupakan bentuk dari kedaulatan rakyat sebagai unsur yang tidak terpisahkan dari negara. Memasukkan solusi hukum asing ke dalam suatu negara harus dengan sangat hati-hati dan harus disesuaikan dengan kekhasan hukum negara penerima.

Spesifik dalam konteks penelitian ini, sejatinya adalah sebuah inisiasi pemikiran untuk mengadopsi sistem yang diterapkan di negara lain dan yang dianggap baik serta mampu memberikan solusi atas permasalahan hukum di Indonesia dalam penyelesaian sengketa Pilkada dengan tetap mengedepankan aspek kompatibilitas dan akseptabilitas dalam sistem hukum Indonesia. Pierre Legrand meneguhkan mengenai ketatnya penerapan transplantasi hukum yang harus menyesuaikan dengan social context suatu negara. ${ }^{91}$ Untuk itu transplantasi hukum tidak dapat melenceng dari desain sistem hukum di suatu negara.

Dalam mendesain kelembagaan adjudikasi, International Institute for Democracy and Electoral Assistance (International IDEA)

87 Jan Torpman dan Fredrik Jörgensen menjelaskan tentang "legal effectiveness" sebagai berikut: "A legal norm is effective in a population of users if users feel confident in their ability to use legal terminology with relevance for the norm, and feel confident that their communication will be accepted as law." Lihat dalam Jan Torpman dan Fredrik Jörgensen, "Legal Effectiveness: Theoretical Developments Concerning Legal Transplants", Archiv Für Rechts und Sozialphilosophie 4 (2005): 22.

88 Martin De Jong dan Virginie Mamadouh, "Two Contrasting Perspectives on Institutional Transplantation", dalam Martin De Jong, Konstantinos Lalenis, dan Virginie Mamadouh (Eds.), The Theory and Practice of Institutional Transplantation: Experiences with the Transfer of Policy Institutions (Dordrecht, The Netherlands: Kluwer Academic Publications, 2002), hlm. 21.

89 Jeremy J. Kingsley menjelaskan potensi kegagalan tersebut dengan menyatakan, "Legal transplants are often unsuccessful if external forces, such as international institutions, assume certain institutional, cultural, or political realities that in fact are not present or properly developed; therefore, these laws are often simply ignored or rejected." Jeremy J. Kingsley, "Legal Transplantation: Is This What the Doctor Ordered and are the Blood Types Compatible? The Application of Interdisciplinary Research to Law Reform in the Developing World - A Case Study of Corporate Governance in Indonesia", Arizona Journal of International and Comparative Law 21:2 (2004): 511. Lihat juga Gary Goodpaster, "The Rule of Law, Economic Development and Indonesia", dalam Timothy Lindsey (Ed.), Indonesia: Law and Society (Sydney: The Federation Press, 1999), hlm. 21-24.

90 Jan M. Smits, "Import and Export of Legal Models: The Dutch Experience", Loc.cit.

91 Pierre Legrand, "The Impossibility of Legal Transplants", Maastricht Journal of European and Comparative Law 4:2 (1997): 121. 
memberikan patokan umum bahwa harus

dikenali terlebih dahulu sifat dan tingkat

keseriusan pembeda sengketa yang timbul dari
Pemilu (recognizing the varying nature and seriousness of different types of complaints and disputes arising from election $)^{92}$. Dalam konteks

92 Chad Vickerey (Ed.), Op.cit., hlm. 126-129. Rekomendasi kriteria dalam pelembagaan adjudikasi Pemilu, yaitu:

a) Election complaints body formation: The election complaints adjudication body is usually referred to as a Complaints Commission, Tribunal, Court, Panel, or other name that reflect its quasi-judicial character. [...] The legislation establishing the complaints body must also specify the number, method of appointment and term of its member, its independence, jurisdiction and powers.

b) Clear jurisdiction: The establishing legislation for the election complaints adjudication body should be clear and should define the following: standing; the required burden of proof for complaints and the nature and sufficiency of evidence; and the jurisdiction of the bodies handling various aspects of the elections process.

c) Independence: The appearance and reality of independence of an election complaints authority derives from the provisions of the law under which it is established; the method of appointment of its members; the professional experience and standing of members; the security the security of funding it receives; its ability to hire and retain competent professional staff who support its independence; and the public respect it gains from the credibility of its election processes. The inclusion of the word "independent" in the provision that establishes the election complaints authority is most important.

d) Membership: Members should ideally be appointed to ensure that they are non-partisan, or, if that is not possible, that the political influence is balanced. Nominations by political parties lead inevitably to politicization and are not recommended. Appropriate nominators include: the courts; an association of universities; a well-established human rights organization; the law society; a national business association; or a national labor organization.

e) Terms of appointment: The term of appointment should be sufficient to encompass preparation and training before the election to the resolution of complaints after the election. Between elections, members should be available on a day-by-day basis for approving reports and making decisions regarding permanent staff, among other duties. Continuity of records and staff expertise would be maintained by the few key staff that would remain.

f) Member characteristics: As an election complaints authority has a quasi-judicial role, its members are usually senior judges or lawyers. In many countries, the amount of time needed for this work would not prevent a judge or lawyer from taking an appointment and maintaining a permanent position as a judge or practicing lawyer. In other countries, the extent and complexity of elections would necessitate a leave of absence.

g) Funding: The electron complaints authority should be funded by an annual budget that comes from the legislature and should not be rooted through the Ministry of Finance. This prevents the governing party from having an undue influence on the budget and places its review before an open, public and multi-party committee.

h) Procedural clarity: The established procedures for the election complaints authority should be clear about the rules for filing an action and provide unambiguous definitions of standing and burdens of proof for specific allegations.

i) Legitimacy: If an election complaints authority functions well, issues clear reports of just decisions, applies proper sanctions and reports serious cases for prosecution. Its own record will establish the public respect that is the best support of independence. This reflects back to the reporting and public information role the key permanent staff can play between elections.

j) Continuity in non-election years: The function of the permanent staff between elections should be to complete and publish the records of the determination of complaints in the past election; review and improve procedures and systems to deal with complaints; participate in public information programs on elections: keep informed on changes in the election process; administer occasional maintenance training for the temporary staff they plan to bring back for subsequent elections; and prepare for subsequent elections.

k) Judicial experience of members: The complaints adjudication process is essentially a judicial assessment and determination. The experience of a judge or possibly a senior lawyer is highly and probably uniquely relevant to the task. A panel of judges, retired fudges or senior lawyer will ensure that key aspects of the determination are professionally addressed.

1) Witness testimony: There is a tendency for political party officials to submit complaints on the basis of party agents' reports. The law, regulations or procedural rules should be clear that the election complaints authority must receive, directly and in person, the evidence of the person who witnessed the offense against the law or the 
Pilkada di Indonesia, tentu saja perkara dan sengketa yang timbul dalam konteks Pilkada membutuhkan lebih dari satu forum untuk menyelesaikannya. Pada titik inilah kemudian kelembagaan adjudikasi khusus menjadi relevan untuk diadakan.

Pengadilan Khusus Pilkada di Indonesia tentu tidak akan didesain sekuat seperti praktik di Uruguay, Brazil, maupun Costa Rica, bahkan harus dituangkan dalam Konstitusi dan dapat merambah cabang kekuasaan negara yang lain, namun lebih relevan bila melihat desain keserentakan yang bersifat musiman, maka didesain dengan sifat ad hoc, yang dibentuk secara khusus menjelang tahapan Pilkada serentak. Hal ini dikarenakan Pilkada serentak bukan merupakan kegiatan tahunan. Selain itu, Pengadilan Khusus Pilkada ini didesain sebagai pengadilan khusus di bawah lingkungan Peradilan Umum pada Mahkamah Agung yang menyatuatapkan segala bentuk sengketa dan perselisihan hasil Pilkada.
Dengan penyatuatapan di satu lembaga adjudikasi khusus, maka mekanisme tersebut akan mampu mengefisienkan penyelesaian sengketa Pilkada yang selama ini masih terpisah-pisah di beberapa lingkungan peradilan, yakni Peradilan Tata Usaha Negara untuk sengketa administrasi, Peradilan Umum untuk penyelesaian tindak pidana, dan untuk perselisihan hasil pada Pengadilan Tinggi yang ditunjuk oleh Mahkamah Agung. Dengan penyatuatapan upaya hukum di bawah Mahkamah Agung, sejatinya membuka peluang untuk dibentuknya suatu pengadilan khusus yang mampu menangani seluruh sengketa yang timbul dari tahapan Pilkada. Hal ini berbeda dengan Uruguay dan Brazil yang mendesain pengadilan pemilunya terpisah dari Supreme Court dan dianggap sebagai Judicial Power yang setingkat Supreme Court. Kewenangan pengadilan Khusus Pilkada Indonesia pun tidak seluas Uruguay dan Brazil yang menangani segala hal terkait pemilu mulai dari aspek administrasi, regulasi sampai yustisi. Pengadilan Khusus

violation of a regulation that founds the complaint, or who has personal knowledge to support the challenge to a candidate. A second hand report from a party official is hearsay and cannot be subjected to questioning.

m) Time limits: The law, regulations or procedural rules must establish time limits for submitting a challenge or complaint. Regarding the submission of complaints of offenses or violations, a short time limit of 24, 48 or 72 hours after the offense or violation was witnessed is sufficient. There is no need to allow time for a political decision to be made on whether to file a complaint. The question of time limits to which the election complaints authority must adhere is problematic. A limit of five or even fifteen days after receiving the complaint may result in the decision being abandoned, and encourage delay by the accused. Critical complaints may well involve complicated investigation. Speed is important, but not at the price of justice.

n) Reasonable sanctions: The election complaints authority must have the power to apply sanctions that are established by law; are reasonable; are proportional to the offense; are varied in range to meet different circumstances; are applied consistently; are not unduly limited by minima that remove discretion; include sanctions that are useful in cases where punitive action is suitable and also corrective, where possible; include disqualification of candidates or dismissal of elections staff for serious offenses; include a referral for criminal prosecution; and if applied, do not exclude additional punishment for included crimes on prosecution.

o) Publication of proper records: A summary of decisions taken should be issued on a regular basis during the challenges and complaints periods. This greatly adds Io the credibility of the process. On the other hand. expectations must be managed. As soon as time permits, a full report should be published, including the details of the more critical decisions. This is a task that the staff can complete for approval by the members, after final results. 
Pilkada hanya akan berfokus pada penyelesaian sengketa yang timbul dalam tahapan Pilkada.

Untuk konteks Indonesia, diharapkan desain kelembagaan dan hukum acara dari pengadilan khusus Pilkada akan mampu menjawab kebutuhan hukum akan sebuah mekanisme upaya hukum yang efisien dan efektif dalam tahapan Pilkada, sehingga tercipta Pilkada yang demokratis dan berkeadilan. Ada 2 (dua) poin pokok yang harus dikaji lebih lanjut terkait pembentukan pengadilan ini, yaitu desain kelembagaan pengadilan khusus Pilkada dan desain hukum acara pengadilan khusus Pilkada.

\section{a) Desain Kelembagaan}

Pengadilan Khusus Pilkada merupakan sebuah pengadilan khusus yang bersifat ad hoc di bawah lingkungan peradilan umum pada Mahkamah Agung. Nomenklatur pengadilan khusus diperkenankan oleh Undang-Undang Nomor 48 Tahun 2009 tentang Kekuasaan Kehakiman dengan pengaturan pengadilan khusus adalah pengadilan yang mempunyai kewenangan untuk memeriksa, mengadili dan memutus perkara tertentu yang hanya dapat dibentuk dalam salah satu lingkungan badan peradilan yang berada di bawah Mahkamah Agung yang diatur dalam undang-undang. ${ }^{93}$

Hal yang harus diperhatikan dari pengaturan tersebut adalah: Pertama, pengadilan khusus hanya dapat dibentuk dalam salah satu lingkungan badan peradilan yang berada di bawah Mahkamah Agung. Merujuk pada Undang-Undang Nomor 48 Tahun 2009 tentang Kekuasaan Kehakiman (UU Kekuasaan
Kehakiman), maka desain kelembagaan pengadilan khusus Pilkada harus dibentuk pada salah satu lingkungan peradilan di bawah Mahkamah Agung, yaitu di antara lingkungan peradilan umum, lingkungan peradilan agama, lingkungan peradilan militer, atau lingkungan peradilan tata usaha negara. ${ }^{94}$ Dengan memperhatikan kompleksitas Pilkada yang akan diselenggarakan serentak pada level kabupaten/ kota dan provinsi, maka lingkungan peradilan umum merupakan lingkungan peradilan yang paling relevan sebagai induk dari pengadilan khusus Pilkada.

Kedua, pengadilan khusus harus dibentuk dalam sebuah Undang-Undang. Pemahaman ini berangkat dari frasa "pengadilan khusus adalah pengadilan [...] yang diatur dalam undangundang". Dalam pendekatan ilmu perundangundangan, frasa tersebut adalah delegatie provisio dalam kaidah bij de wet geregeld, yang maknanya pembentukan pengadilan khusus dibentuk melalui Undang-Undang yang tidak harus mengatur khusus mengenai pengadilan khusus Pilkada. Pembentukan dan pengaturan mengenai pengadilan khusus Pilkada dapat disisipkan pada pengaturan dalam UU Pilkada.

Hallainyang harus diperhatikanadalah desain pengadilan khusus Pilkada sebagai pengadilan khusus ad hoc. Dalam hukum positif Indonesia, kelembagaan pengadilan ad hoc dikenal pada Pengadilan Hak Asasi Manusia (HAM) menurut Undang-Undang Nomor 26 Tahun 2000 tentang Pengadilan Hak Asasi Manusia (UU Pengadilan HAM $)^{95}$. Dengan menggunakan padanan definisi 
hakim ad hoc pada UU Kekuasaan Kehakiman, ${ }^{96}$ maka pengadilan khusus ad hoc dapat dimaknai pengadilan khusus yang bersifat sementara yang memiliki kompetensi absolut dan relatif di bidang tertentu untuk memeriksa, mengadili, dan memutus suatu perkara yang diatur dalam undang-undang. Desain kesementaraan pengadilan khusus Pilkada dikarenakan pengadilan hanya akan dibentuk pada saat menjelang proses Pilkada, yaitu paling lambat 6 (enam) bulan sebelum tahapan pertama penyelenggaraan Pilkada dimulai dan berakhir paling lambat 1 (satu) tahun setelah seluruh tahapan penyelenggaraan Pilkada selesai.

Terkait dengan tempat kedudukan pengadilan khusus Pilkada akan berada sesuai dengan kompetensi yang dimilikinya. Pengadilan khusus Pilkada untuk pemilihan Gubernur akan melekat pada Pengadilan Tinggi pada level provinsi, sedangkan untuk pemilihan Bupati/Walikota pengadilan khusus Pilkada akan melekat pada Pengadilan Negeri pada level Kabupaten/Kota. Dengan desain tersebut maka dapat dicapai efisiensi penyelesaian perkara, mengingat kasus Pilkada relatif banyak dengan tuntutan waktu penyelesaian secepat mungkin

Melihat aspek kompetensi, pengadilan khusus Pilkada didesain memiliki kewenangan untuk menangani segala sengketa yang timbul dalam proses Pilkada, mulai dari sengketa administrasi dan tindak pidana Pilkada, hingga perselisihan hasil Pilkada. Sedangkan untuk pelanggaran kode etik penyelenggara Pilkada, akan tetap menjadi kewenangan dari Dewan Kehormatan Penyelenggara Pemilihan Umum (DKPP). Walaupun Pilkada bukan lagi rezim pemilihan umum (Pemilu), namun merujuk pada Undang-Undang Nomor 15 Tahun 2011 tentang Penyelenggara Pemilihan Umum (UU Penyelenggara Pemilu) ${ }^{97}$, penyelenggaraan Pilkada merupakan domain kewenangan Komisi Pemilihan Umum (KPU). ${ }^{98}$ Dengan demikian, pelanggaran kode etik KPU sebagai penyelenggara Pilkada akan tetap dilaksanakan oleh DKPP.

Dengan keberadaan pengadilan khusus Pilkada, hal lain melekat adalah revitalisasi peran Badan Pengawas Pemilihan Umum (Bawaslu). Keseluruhan kompetensi pengadilan khusus Pilkada akan melibatkan peran dari Bawaslu Provinsi dan Panitia Pengawas Pemilihan Umum (Panwaslu) Kabupaten/Kota sebagai penyidik sekaligus penuntut umum dalam perkara pidana Pilkada, sehingga dengan demikian keberadaan pengadilan khusus Pilkada secara otomatis akan merevitalisasi peranan Bawaslu dalam Pilkada.

Adapun terkait komposisi hakim pada pengadilan khusus Pilkada, akan terdiri dari 2 (dua) orang hakim karier dan 1 (satu) orang akademisi hukum. Perspektif akademis diharapkan mampu memberikan perspektifyang memperkaya kualitas putusan dalam mengadili perkara Pilkada. Putusan yang dihasilkan oleh pengadilan khusus Pilkada bersifat final dan mengikat, sehingga diharapkan kepastian hukum dapat segera diperoleh oleh justiciable.

96 Pasal 1 angka 8 Undang-Undang Nomor 48 Tahun 2009 tentang Kekuasaan Kehakiman (Lembaran Negara Republik Indonesia Tahun 2009 Nomor 157, Tambahan Lembaran Negara Republik Indonesia Nomor 5076).

97 Pasal 1 angka 4 Undang-Undang Nomor 15 Tahun 2011 tentang Penyelenggara Pemilihan Umum (Lembaran Negara Republik Indonesia Tahun 2011 Nomor 101, Tambahan Lembaran Negara Republik Indonesia Nomor 5246).

98 Pasal 8 ayat (3) Undang-Undang Nomor 15 Tahun 2011 tentang Penyelenggara Pemilihan Umum (Lembaran Negara Republik Indonesia Tahun 2011 Nomor 101, Tambahan Lembaran Negara Republik Indonesia Nomor 5246). 


\section{b) Hukum Acara}

Sebagaimana telah dijelaskan di atas, bahwa pengadilan khusus Pilkada memiliki kompetensi menangani segala sengketa yang timbul dalam proses Pilkada, mulai dari sengketa administrasi dan tindak pidana Pilkada, hingga perselisihan hasil Pilkada. Pertama, sengketa administrasi Pilkada. Sengketa administrasi dapat lahir karena adanya keputusan tata usaha negara lembaga penyelenggara Pilkada yang merugikan masyarakat yang memiliki hak pilih dan/atau calon kepala daerah. Sengketa administrasi juga dapat dimungkinkan karena adanya pelanggaran terhadap keputusan tata usaha negara lembaga penyelenggara Pilkada oleh calon kepala daerah, seperti misalnya pelanggaran masa kampanye. Untuk sengketa yang lahir karena keputusan tata usaha negara lembaga penyelenggara Pilkada, maka pihak yang merasa terugikan dapat langsung mengajukan gugatan administrasi ke pengadilan khusus Pilkada. Sedangkan untuk perkara yang timbul karena adanya pelanggaran terhadap keputusan tata usaha negara lembaga penyelenggara Pilkada oleh calon kepala daerah, maka masyarakat harus melaporkan pada Bawaslu/Panwaslu disertai dengan buktibukti. Selanjutnya Bawaslu/Panwaslu akan membawa hal ini untuk diputus di pengadilan khusus Pilkada.

Kedua, tindak pidana Pilkada. Bila disinyalir terdapat tindak pidana Pilkada, laporan diajukan kepada Bawaslu untuk selanjutnya diselidiki dan disidik sebelum dilimpahkan pada proses penuntutan yang akan dilakukan pula oleh Bawaslu. Bawaslu dalam hal ini memiliki peran yang sangat besar dan vital, yaitu sebagai penyidik sekaligus penuntut umum. Ketentuan tersebut memang menyimpang dari diferensiasi fungsional yang ada dalam sistem peradilan pidana, namun hal tersebut sah untuk tetap didesain mengingat sifat khusus dari tindak pidana Pilkada. Setelah melalui proses penyidikan dan penuntutan dengan disertai bukti-bukti yang cukup, maka laporan tindak pidana Pilkada dapat diajukan untuk diperiksa di persidangan oleh hakim pada pengadilan khusus Pilkada.

Ketiga, perselisihan hasil Pilkada. Hasil Pilkada yang telah ditetapkan oleh KPU dapat diajukan ke pengadilan khusus Pilkada oleh calon kepada daerah yang mendalilkan ada selisih suara antara perhitungan KPU dengan perhitungan suara yang didalilkan merupakan suaranya. Inilah upaya hukum bagi calon kepala daerah untuk memohon pembatalan penetapan hasil penghitungan suara.

Keseluruhan proses penyelesaian sengketa dan perselisihan hasil Pilkada, harus mempertimbangkan kecepatan waktu demi menjaga tercederainya keadilan bagi para pihak. Oleh karena itu, jangka waktu antara laporan dengan pembacaan putusan Majelis Hakim juga harus dibatasi dalam jangka waktu tertentu, setidaktidaknya 3 (tiga) bulan.

\section{Penutup}

Sebagai penutup, pengadilan khusus Pilkada merupakan sebuah pembaharuan yang relevan untuk diadakan mengingat legal policy untuk menyelenggarakan Pilkada serentak pada tahun 2027. Terlebih, pengadilan khusus Pilkada ini telah dilaksanakan di beberapa negara yang berarti menunjukkan keberadaannya bukan suatu hal yang tabu. Akan tetapi, desain Pengadilan Khusus Pilkada di Indonesia tentu harus disesuaikan dengan kondisi negara, sehingga Penulis merumuskan bahwa desain yang sesuai adalah bersifat ad hoc, berada di bawah Mahkamah Agung, serta memiliki kewenangan untuk menangani 
segala sengketa yang timbul dalam proses Pilkada, mulai dari sengketa administrasi dan tindak pidana Pilkada, hingga perselisihan hasil Pilkada. Sedangkan untuk pelanggaran kode etik penyelenggara Pilkada, akan tetap menjadi kewenangan dari DKPP. Dengan keberadaan pengadilan khusus Pilkada, hal lain melekat adalah revitalisasi peran Bawaslu. Keseluruhan kompetensi pengadilan khusus Pilkada akan melibatkan peran dari Bawaslu Provinsi dan Panwaslu Kabupaten/Kota sebagai penyidik sekaligus penuntut umum dalam perkara pidana Pilkada, sehingga dengan demikian keberadaan pengadilan khusus Pilkada secara otomatis akan merevitalisasi peranan Bawaslu dalam Pilkada. Gagasan membentuk pengadilan khusus Pilkada ini merupakan sebuah gagasan awal yang harus diperkaya dan diperdalam untuk selanjutnya dapat diformulasikan secara utuh dan komprehensif mengenai pengadilan khusus Pilkada.

Sebagai saran, seluruh desain Pengadilan Khusus Pilkada ini sebaiknya dirumuskan dan dituangkan dalam peraturan perundangundangan, yang mana pembentukan pengadilan khusus dibentuk melalui Undang-Undang yang tidak harus mengatur khusus mengenai pengadilan khusus Pilkada. Pembentukan dan pengaturan mengenai pengadilan khusus Pilkada dapat disisipkan pada pengaturan dalam UU Pilkada. Pembaharuan untuk membentuk Pengadilan Khusus Pilkada patut segera dilaksanakan semata dalam rangka meningkatkan kualitas Pilkada bukan semata sebagai ritual politik, namun harus didorong sebagai upaya demokratisasi di daerah, namun lebih jauh menciptakan Pilkada yang berkeadilan.

\section{DAFTAR PUSTAKA}

\section{Buku}

Amiruddin dan Zainal Asikin, Pengantar Metode Penelitian Hukum (Jakarta: RajaGrafindo Persada, 2004).

Goodpaster, Gary, "The Rule of Law, Economic Development and Indonesia", dalam Timothy Lindsey (Ed.), Indonesia: Law and Society (Sydney: The Federation Press, 1999).

Jong, Martin De dan Virginie Mamadouh, "Two Contrasting Perspectives on Institutional Transplantation", dalam Martin De Jong, Konstantinos Lalenis, dan Virginie Mamadouh (Eds.), The Theory and Practice of Institutional Transplantation: Experiences with the Transfer of Policy Institutions (Dordrecht, The Netherlands: Kluwer Academic Publications, 2002).

Mahkamah Konstitusi, Prosiding Seminar Nasional Pemilihan Umum Kepala Daerah (Jakarta: Kepaniteraan dan Sekretariat Jendral Mahkamah Konstitusi Republik Indonesia, 2012).

Marzuki, Peter Mahmud, Penelitian Hukum (Jakarta: Kencana, 2005).

Pound, Roscoe, The Formative Era of American Law, (Boston: Little, Brown, and Co., 1938).

Ritaine, Eleanor Cashin, "Legal Engineering in Comparative Law - An Introduction", dalam Eleanor Cashin Ritaine (Ed.), Legal Engineering and Comparative Law (L'ingénierie juridique et le droit comparé) (Genève: Schulthess, 2009).

Smits, Jan M., "Legal Engineering in an Age of Globalisation: Is There a Future for Jurisdictional Competition?", dalam Eleanor Cashin Ritaine (Ed.),Legal Engineering and Comparative Law (L'ingénierie juridique et le droit comparé) (Genève: Schulthess, 2009).

Soekanto, Soerjono dan Sri Mamudji, Penelitian Hukum Normatif Suatu Tinjauan Umum (Jakarta: RajaGrafindo Persada, 2007).

Soemitro, Ronny Hanitijo, Metodologi Penelitian Hukum (Jakarta: Ghalia Indonesia, 1985).

Metodologi Penelitian Hukum dan Jurimetri (Jakarta: Ghalia Indonesia, 1988).

Staino, Sara, "Case Study: Uruguay: The Electoral Court-A Fourth Branch of Government?", dalam Alan Wall, et al., Electoral Management Design: The International IDEA Handbook (Stockholm: IDEA, 2006). 
Sumardjono, Maria S.W., Pedoman Pembuatan Usulan Penelitian: Sebuah Panduan Dasar (Jakarta: Gramedia, 2001).

Suriasumantri, Jujur S., IImu dalam Perspektif Moral, Sosial dan Politik: Sebuah Dialog tentang Keilmuan Dewasa Ini (Jakarta: Gramedia, 1986).

Valle, Rubén Hernández, "Case Study: Costa Rica: A Powerful Constitutional Body", dalam Alan Wall, et al., Electoral Management Design: The International IDEA Handbook (Stockholm: IDEA, 2006).

Vickery, Chad et al., Guidelines for Understanding, Adjudicating and Resolving Disputes in Elections (Washington DC.: USAID and IFES, 2011).

Waluyo, Bambang, Penelitian Hukum dalam Praktik (Jakarta: Sinar Grafika, 2002).

\section{Makalah/Artikel/Prosiding/Hasil Penelitian}

Ball, Harry V., dan Lawrence M. Friedman, "The Use of Criminal Sanctions in the Enforcement of Economic Legislation: A Sociological View", Stanford Law Review 17:2, (1965).

Beckstrom, John H., "Handicaps of Legal-Social Engineering in a Developing Nation", American Journal of Comparative Law 22: 4 (1974).

Damardono, A. Haryo dan Anita Yossihara, "Paripurna DPR Sahkan Pilkada Langsung" (Kompas, 20 Januari 2015).

Fauzi, Gamawan, "Keterangan Pemerintah Atas Rancangan Undang-Undang tentang Pemerintahan Daerah" (Rapat Kerja Pansus Rancangan Undang-Undang tentang Pemerintahan Daerah, Jakarta, 3 April 2012).

Kingsley, Jeremy J., "Legal Transplantation: Is This What the Doctor Ordered and are the Blood Types Compatible? The Application of Interdisciplinary Research to Law Reform in the Developing World - A Case Study of Corporate Governance in Indonesia", Arizona Journal of International and Comparative Law 21:2 (2004).

Langer, Máximo, "From Legal Transplants to Legal Translations: The Globalization of Plea Bargaining and the Americanization Thesis in Criminal Procedure", Harvard International Law Journal 45: 1 (2004).

Legrand, Pierre, "The Impossibility of Legal Transplants", Maastricht Journal of European and Comparative Law 4:2 (1997).

Petit, Denis, "Resolving Election Disputes in the OSCE Area: Towards a Standard Election Dispute
Monitoring System", (ODIHR Rule of Law Expert, Warsaw, 2000).

Tordoff, William, "Decentralisation: Comparative Experience in Commonwealth Africa", The Journal of Modern African Studies 32:4 (1994).

Torpman, Jan dan Fredrik Jörgensen, "Legal Effectiveness: Theoretical Developments Concerning Legal Transplants", Archiv Für Rechts und Sozialphilosophie 4 (2005).

\section{Internet}

Badan Legislasi Dewan Perwakilan Rakyat Republik Indonesia, "Rancangan Undang-Undang Republik Indonesia Nomor ... Tahun 2015 Perubahan Atas Undang-Undang Nomor 1 Tahun 2015 tentang Penetapan Peraturan Pemerintah Pengganti Undang-Undang Nomor 1 Tahun 2014 tentang Pemilihan Gubernur, Bupati, dan Walikota Menjadi Undang", http://www.dpr. go.id/dokakd/dokumen/BALEG-6-108aa1a82 bd52a99324db8b199f67794.pdf, (diakses 11 Maret 2015).

Country Studies US, "The Consolidation of Political Democracy", http://countrystudies.us/uruguay/ 13.htm, (diakses 4 Maret 2015).

Dewan Perwakilan Rakyat Republik Indonesia, "Paripurna DPR Setujui Revisi UU Pilkada dan RUU Pemda Menjadi UU", http://dpr.go.id/ berita/detail/id/9734, (diakses 11 Maret 2015).

Superior Electoral Court, "History of the Elections", http://english.tse.jus.br/history-of-theelections/the-empire, (diakses 2 Maret 2015).

Susila, Suryanta Bakti dan Agus Rahmat, "Akan Dibentuk Peradilan Khusus Sengketa Pilkada", http://politik.news.viva.co.id/news/ read/590742-akan-dibentuk-peradilan-khusussengketa-pilkada, (diakses 11 Maret 2015).

\section{Peraturan}

Constitution of Brazil 1988 (rev. 2014).

Constitution of Costa Rica 1949 (rev. 2011).

Constitution of Uruguay 1966 (reinst. 1985, rev. 2004).

Putusan Mahkamah Konstitusi Nomor 97/PUU$\mathrm{XI} / 2013$ perihal Pengujian Undang-Undang Nomor 12 Tahun 2008 tentang Perubahan Kedua Atas Undang-Undang Nomor 32 Tahun 2004 tentang Pemerintahan Daerah dan Undang-Undang Nomor 48 Tahun 2009 tentang Kekuasaan Kehakiman terhadap Undang- 


\section{R Junah HTSVINDING}

Media Pembinaan Hukum Nasional

Undang Dasar Negara Republik Indonesia Tahun 1945.

Surat Kementerian Dalam Negeri Republik Indonesia Nomor 120/4474/OTDA perihal Konfirmasi Data Akhir Masa Jabatan Kepala Daerah Tahun 2015, tanggal 29 Oktober 2014.

Undang-Undang Dasar Negara Republik Indonesia Tahun 1945.

Undang-Undang Nomor 26 Tahun 2000 tentang Pengadilan Hak Asasi Manusia (Lembaran Negara Republik Indonesia Tahun 2000 Nomor 208, Tambahan Lembaran Negara Republik Indonesia Nomor 4026).

Undang-Undang Nomor 48 Tahun 2009 tentang Kekuasaan Kehakiman (Lembaran Negara Republik Indonesia Tahun 2009 Nomor 157, Tambahan Lembaran Negara Republik Indonesia Nomor 5076).

Undang-Undang Nomor 15 Tahun 2011 tentang Penyelenggara Pemilihan Umum (Lembaran

\section{Volume 4, Nomor 1, April 2015}

Negara Republik Indonesia Tahun 2011 Nomor 101, Tambahan Lembaran Negara Republik Indonesia Nomor 5246).

Undang-Undang Nomor 1 Tahun 2015 tentang Penetapan Peraturan Pemerintah Pengganti Undang-Undang Nomor 1 Tahun 2014 tentang Pemilihan Gubernur, Bupati, dan Walikota Menjadi Undang-Undang (Lembaran Negara Republik Indonesia Tahun 2015 Nomor 23, Tambahan Lembaran Negara Republik Indonesia Nomor 5656).

Undang-Undang Nomor 8 Tahun 2015 tentang Perubahan Atas Undang-Undang Nomor 1 Tahun 2015 tentang Penetapan Peraturan Pemerintah Pengganti Undang-Undang Nomor 1 Tahun 2014 tentang Pemilihan Gubernur, Bupati, dan Walikota Menjadi Undang-Undang (Lembaran Negara Republik Indonesia Tahun 2015 Nomor 57. Tambahan Lembaran Negara Republik Indonesia Nomor 5678). 